\title{
Diversity and structure of a bird community in a logged forest in south-east Côte d'Ivoire
}

\author{
Dissertation \\ zur Erlangung des Doktorgrades \\ der Mathematisch-Naturwissenschaftlichen Fakultäten \\ der Georg-August-Universität zu Göttingen
}

vorgelegt von

Dipl. Biol. Matthias Waltert

aus Tauberbischofsheim

Göttingen 2000 
D7

Referent: Prof. Dr. M. Mühlenberg

Korreferent: Prof. Dr. R. Willmann

Tag der mündlichen Püfung: 27.04.2000 


\section{Foreword}

Tropical rain forests constitute the most species-rich and ecologically complex terrestrial communities on earth. However, processes such as land conversion for agriculture, logging for timber or poaching put high pressures on tropical forests world-wide. Ecological changes at the turn of the $20^{\text {th }}$ century were and continue to be so massive and rapid that biological science will not be able to assess even basic characteristics of forest ecosystems before their majority is lost. Hence, one of the most challenging tasks of tropical biology is to describe biodiversity in unmodified systems, where ecological processes relevant to the origin and maintenance of biodiversity are studied. In contrast, only few attention has been paid to the description of community patterns in faunas and floras already altered by man or presently subject to disturbance.

However, human impact studies in tropical forests do and will play a very important role as most tropical forests can only persist as production forests (see Parren \& de Graaf 1995). Questions concerning ecologically sound management plans cannot be answered without proper assessment in managed forest areas. Most studies on the alteration of forest fauna and flora due to fragmentation or timber exploitation are short-term approaches and are complicated by the fact that fragmentation, isolation or degradation processes often interconnect. Observed patterns often result from more than one process, making an analytical approach and the understanding of human impact more difficult (Crome 1997). Furthermore, as deforestation in the tropics is a very recent and still ongoing process, the dimension of fragmentation or habitat degradation effects will only be noticeable in the future, especially in longer-living organisms such as trees or vertebrates (Brooks \& Balmford 1996, Brooks et al. 1999).

Whereas wildlife biologists spent much time with difficulties of impact assessments in forest ecosystems, forest managers and economists could relatively easy claim sustainability for their operations. In contrast to biologists, they can more quickly present data, e.g. on the recruitment of commercial timber species (see discussion in Struhsaker 1997). Only in the last years and with the help of long-term research, biologists could document the adverse effects of disturbing processes such as habitat degradation or fragmentation on the forest fauna (e.g. Laurance \& Bierregaard 1997, Struhsaker 1997).

However, the ecology of tropical secondary forests is still far from being understood. Further research on ecologically sound management techniques and the appropriate size of managed forest areas is urgently needed. The establishment of forest reserves and management plans combining economy and ecology is often the only adequate strategy for developing countries to preserve a considerable proportion of their rainforest biodiversity. Economically inefficient reserves are not at all protected against irreversible land conversion, and are often rapidly cleared for other crops, e.g. cocoa and coffee. 


\section{Acknowledgements}

The Kreditanstalt für Wiederaufbau (KfW) and the Gesellschaft für Technische Zusammenarbeit (GTZ) supported this project. I am especially grateful to Dr. H.J. Wöll, Dr. W.E. Waitkuwait, Dr. H. Fickinger (all GTZ), Mr. J.C. E. Anoh, Mr. Gbanzai, Mr. Bamba Singo, Mr. N'Dri Pascale and Mr. Aze N'Da (all SODEFOR). I am also grateful to the GTZteam in Abidjan, especially Helga and Mamadou.

Special thanks go to my supervisors Prof. Dr. M. Mühlenberg, Dr. J. Slowik and Dr. M. Louette, who appreciated and supported my work from the beginning. Also, I'd like to thank Prof. Dr. Mühlenberg and Dr. B. Steinhauer-Burkart for enabling visits to other parts of West Africa.

During fieldwork, I particularly learned from the mist-netting skills of Mr. W. Jetz.

Dr.Ugo Dall'Asta, Mr. Fane Adama, Mr. Aka Kouadio, Mr. Yaokokoré-Beibro K. Hilaire, Mr. Kouablan Tanoh, Mr. Djame Tanoh ${ }^{\dagger}$, Francis, D. Unger and H. Fermon also helped in many ways.

For invaluable assistance with field identification I thank Dr. M. Louette (Royal Museum for Central Africa, Tervuren), Dr. C. Chappuis (La Bouille), Dr. L.D.C. Fishpool (Birdlife International, Cambridge) and Mr. R Demey (Den Haag). I also thank Dr. J.-M. Thiollay (Paris) and Dr. L.D.C. Fishpool for refereeing check-lists.

For discussions, I thank Dr. M. Louette, Dr. U. Dall'Asta, Dr. R. Jocqué (all Tervuren), Dr. C. Chatelain (Genf), Dr. J. Fjeldså (Copenhagen), D. Nett (Hamburg), K. Barnes (Cape Town), Dr. L.H. Holbech (Accra), Dr. E. Gottschalk (Göttingen) and H. Fermon.

I am also very grateful for the friendship and hospitality of Ekki and Solange in Abengourou. Special thanks for assistance in Appouesso to Beibro, Odile, Yvonne ${ }^{\dagger}$, Ugo and Karim.

My thanks also to the team of the Zentrum für Naturschutz: Prof. Dr. M. Mühlenberg, Dr. J. Slowik, Dr. E. Gottschalk, H. Hondong, M. Deseniß, S. Thies, P. Melchert and E. Opielka.

Thanks to my parents Bruno and Vroni and also to Moe en Va for the wonderful times whenever we were togeher in Königheim or Aalst.

The most special thank you goes to Heleen who read and corrected manuscripts and reports, prepared spot maps and vegetation data. Thank you for taking over organisation during my absences and while I wrote this thesis. 


\section{Contents}

\section{Foreword}

\section{Acknowledgements}

1. Introduction

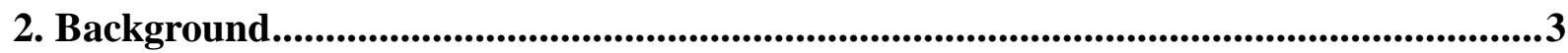

2.1 Notes on species richness, endemism and ecology of the Upper Guinean forest avifauna ....................................................................................................................3

2.2 Status of Upper Guinean forests and possible threats to the avifauna ....................5

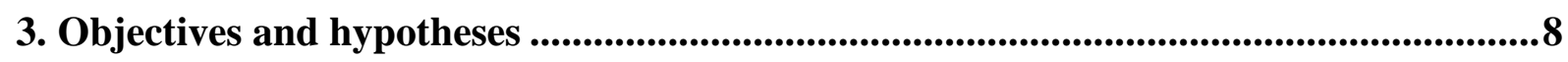

4. Study area ...........................................................................................................................................11

4.1 Geology, climate and soils .........................................................................................13

4.2 Vegetation, logging history and mammal fauna ........................................................15

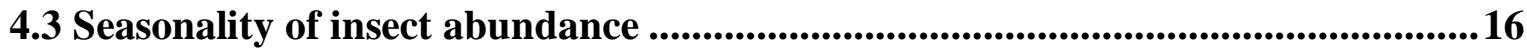

4.4 Management plan, silvicultural practices and biomonitoring .............................18

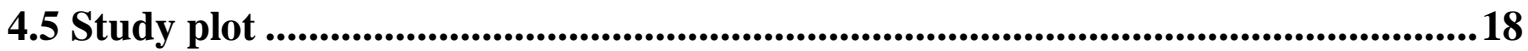

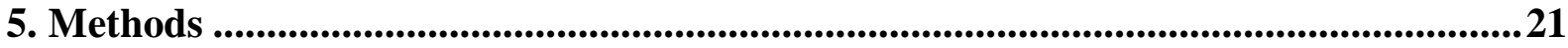

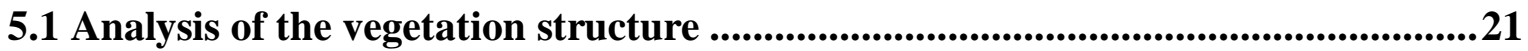

5.2 Ornithological fieldwork ............................................................................................22

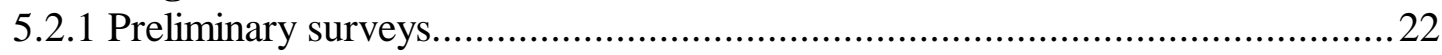

5.2.2 Standardised mist-netting .............................................................. 22

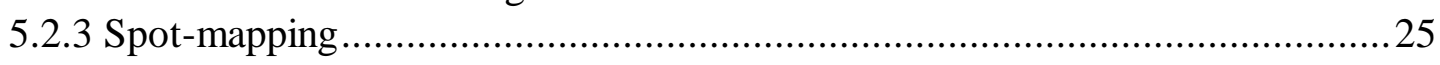

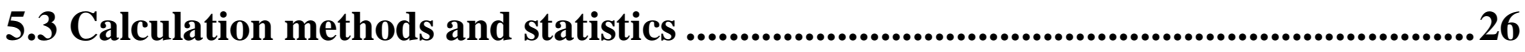

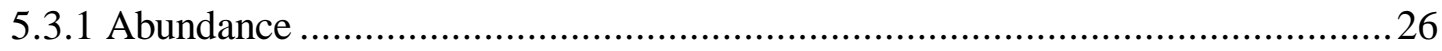

5.3.2 Calculation of community parameters ....................................................... 27

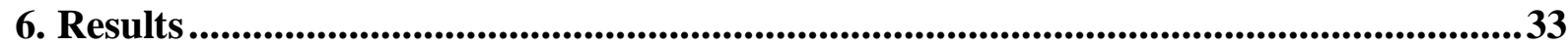

6.1 Vegetation structure of the Forêt Classée.................................................................33

6.2 Vegetation structure of the study plot: management effects .................................33

6.3 Avifauna of the region......................................................................................36

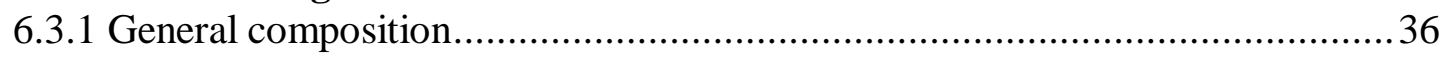

6.3.2 Comparison of the Bossematié area with the Taï region .................................36

6.3.3 Comparison of the Bossematié Forest with Bia National Park ......................... 37

6.3.4 $\alpha$-Diversity of understorey birds in the Bossematié and other forests...............38

6.3.5 The Bossematié forest compared to the surrounding area..............................39

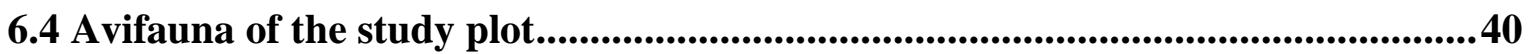

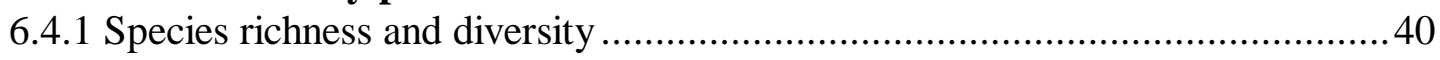




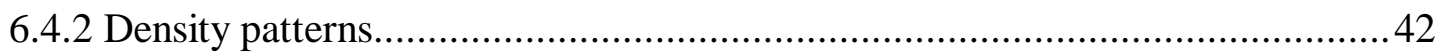

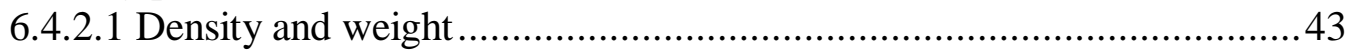

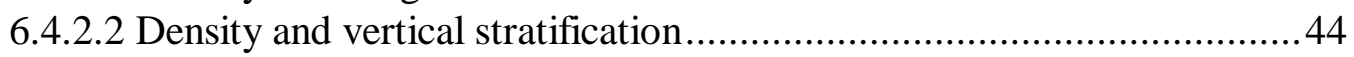

6.4.2.3 Density and geographic range........................................................4 45

6.4.2.4 Density and diet ......................................................................4 45

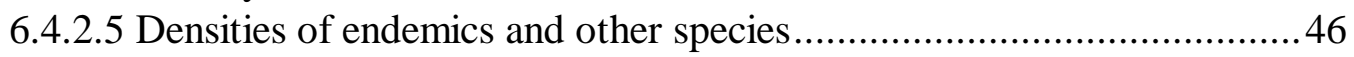

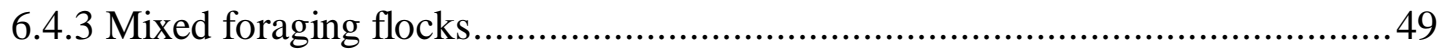

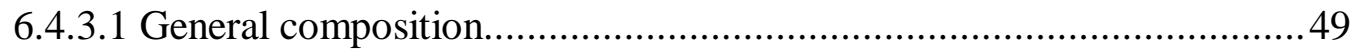

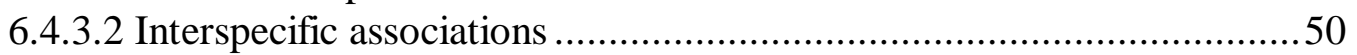

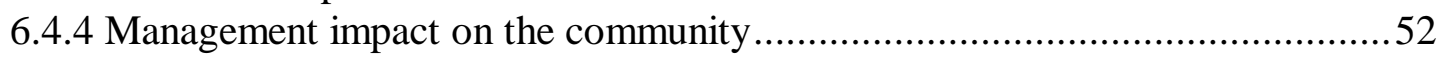

6.4.4.1 Abundance, species richness and diversity.......................................52

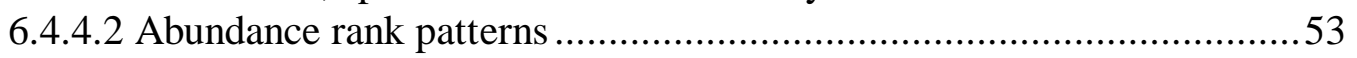

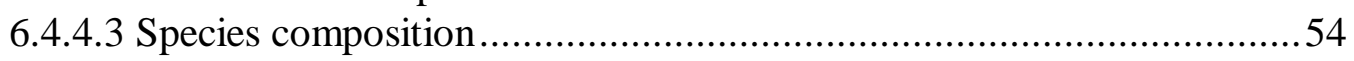

6.4.4.4 Interspecific comparisons of habitat preferences ..............................55

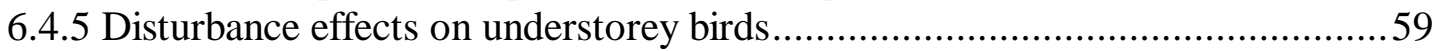

6.4.5.1 Differences in mist-net data between sampling periods.......................59

6.4.5.2 Differences between compartments..................................................64

6.4.6 Comparative efficiency of mist-netting and mapping ................................. 80

6.5 Capture rates and habitat quality: the case of the Yellow-whiskered Greenbul..80

7. Discussion.............................................................................................................8

7.1 Logging, forest management and vegetation structure............................................82

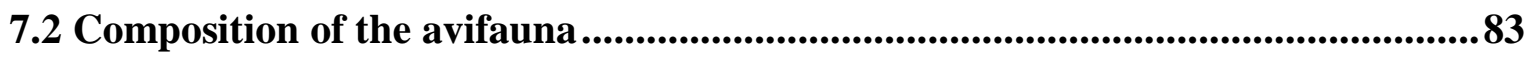

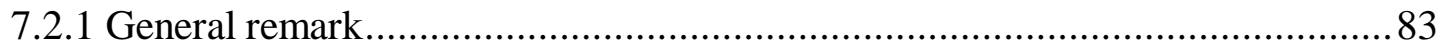

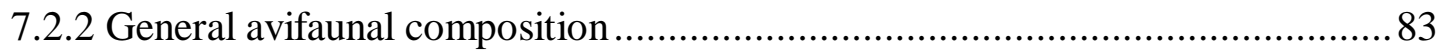

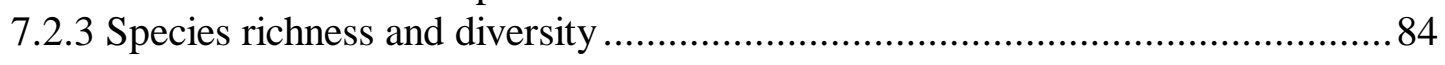

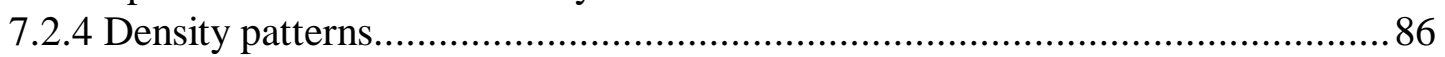

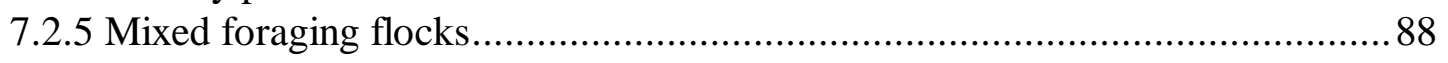

7.3. Management impact on the community ..............................................................89

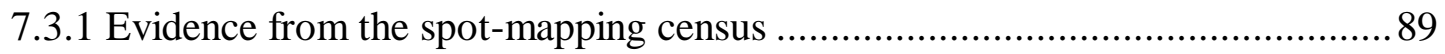

7.3.2 Avifaunal results compared to results on butterflies..................................... 90

7.3.3 Impact assessment by mist-netting ...................................................... 90

7.4 Inferring habitat quality from capture rates........................................................91

7.5 Are Upper Guinean forest birds ecologically resilient? .......................................94

7.6 Considerations on forest management ......................................................................95

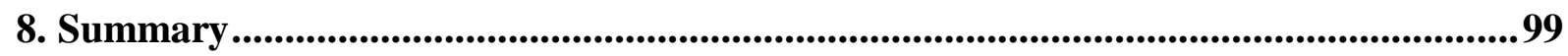

9. Résumé ............................................................................................................ 102

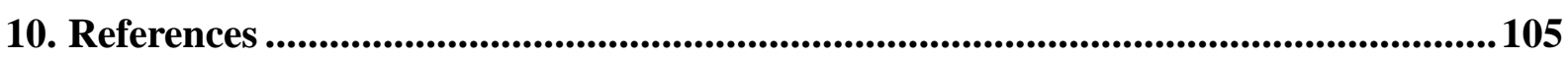

Appendix A Systematic list of the birds of the Bossematie area

Appendic B Species mist-netted within the study plot

Appendix C Population data for the 136 bird species recorded within the 110 ha study plot

Appendix D Spot maps

Appendix E Photographic Section 


\section{Introduction}

Vertebrates are important components of tropical forest ecosystems. A decrease in or lack of some vertebrate species acting as seed dispersers or pollinators influences the viability of many plants, and may cause important long-term changes in the composition of forests (AllenWardell et al. 1998, Robertson et al. 1999). Among other vertebrates such as fruitbats or primates (Payne 1995), many bird species play a key role in these interactions (e.g. Lock 1986, Whitney \& Smith 1998, Goldblatt 1999, Sazima \& Sazima 1999).

Logging, slash and burn agriculture, shifting cultivation and the establishment of plantation systems cause fragmentation and habitat change in tropical rain forest regions. Despite the increasing concern about deforestation and conversion of forest into other land-use systems, their impact on rainforest biodiversity has rarely been assessed (Lawton et al. 1998). However, ecological changes can be dramatic: in Liberia, a 70\% loss of bird species was reported after the conversion of forest into farmland (e.g. Kofron \& Chapman 1995).

Within the humid tropics, especially in West Africa timber exploitation and subsequent conversion of forest into farmland has led to dramatic decreases of forest cover (Barnes 1990). Highest deforestation rates are reported from the Côte d'Ivoire. All over the country, but especially in its eastern parts, forests are fragmented and timber-depleted (see also forest cover maps of WWF 2000). Furthermore, a high percentage of the forest reserve areas have been occupied illegally by farmers growing food and cash crops such as coffee and cocoa (Parren \& de Graaf 1995). In addition, poaching is considered being the major threat for large birds and mammals (e.g. McGraw et al. 1998).

After the Rio conference, national governments worldwide started activities to stop uncontrolled exploitation of forests estates and developed controlled land-use planning and management. In 1990, a pilot project started in eastern Côte d'Ivoire which included several forest reserves in a rehabilitation program in co-operation with the private sector and international institutions. Main objectives are the rehabilitation of degraded forest areas and the development of ecologically sound management techniques. The maintenance of biodiversity and important ecological functions are also major components of the program (Wöll 1992).

In this study, the composition of a bird community of a secondary forest remnant will be described and compared with available data from other forest reserves. In addition, the effects of recently applied forest management are assessed. Since natural regeneration, liberation thinning and plantation management are the principal measures of (natural) forest management in eastern Côte d'Ivoire, these three management types are studied more in detail. 
The investigations are carried out on three different scales:

- the regional scale: qualitative comparisons of the bird community with reference areas (Taï and Bia National Park);

- the local scale: quantitative analysis of bird diversity and community structure in the logged forest avifauna and impact assessment of forest management;

- the population level: habitat use and individual turnover in understorey bird species using standard mark-recapture procedures.

An avifaunal list of the study area is found in Waltert et al. (1999). First results on the impact of liberation thinning (or "selective cleaning") on the vegetation structure and the distribution of understorey birds are published in Waltert (2000). 


\section{Background}

\subsection{Notes on species richness, endemism and ecology of the Upper Guinean forest avifauna}

Fig. 1. shows the original distribution of humid forests in the Upper Guinean region. The principal forest types, ranging from the coastline to the forest-savannah boundary, are lowland wet evergreen and moist semi-deciduous forests. Mangrove and swamp forest only occur along the littoral fringes and montane forest with its specific vegetational characteristics appears in the Nimba region, where Côte d'Ivoire, Liberia and Guinea meet (Sayer et al. 1992).

Some 278 bird species are centred on the Guinea-Congolian rainforest biome (Fishpool 1997 and in prep.), including the Upper Guinean Endemic Bird Area (EBA 084, with fifteen endemic species), the Cameroon/Gabon lowlands (EBA 085, with five endemic species) and the Cameroon mountains (EBA 086, with 27 endemic species) (Stattersfield et al. 1998). From the Guinea-Congolian rainforest biome, some 180 bird species have been recorded in Côte d'Ivoire (Fishpool 1997 and in prep.). About the same number of forest species, 182, has been described for the lowland forest avifauna of Upper Guinean forests (Moreau 1966). Fourteen out of the fifteen Upper Guinean endemics occur in Côte d'Ivoire. The ranges of most Upper Guinean endemics are centred on the Liberia-Western Côte d'Ivoire area, where a major Pleistocene refuge has been postulated. Nine of these have been recorded also in the eastern part of the EBA, where a small sub-centre of endemism exists (Guillaumet 1967, van Rompaey 1993).

In the 180 Guinea-Congolian species in Côte d'Ivoire, only those species depending to a considerable extent on forests are included. Here, forest species are defined as in Moreau (1966) or Amadon (1973) and species common in forests but depending on non-forest habitat resources are not considered. In this sense, most herons and egrets Ardeidae are excluded, whereas the African Tiger Bittern Tigriornis leucolophus, only living in forested areas, is included.

In comparison with other, similar-sized tropical lowland forest areas, these figures of species richness and endemism are low (Haffer 1974, Keast 1990, Stattersfield et al. 1998). The low bird species richness in the Upper Guinean region and within single forest areas is accompanied by a generally low habitat specialisation. Although bird species diversity seems to be highest in lowland forest (Thiollay 1985a), only few species seem to be restricted to this forest type (Grimes 1987, review of Keast 1990, Gatter 1998). Most forest birds occur in considerable densities from the coastline to the forest-savannah boundary and can be found even in forest galleries and montane areas. In an intercontinental comparison, Africa is indeed outstanding by its relatively few forest specialists. In other tropical regions, a much higher specialisation to certain forest types is visible (c. $40 \%$ in the Neotropics, 50\% in the Indo-Malayan and 25\% in the Australian region against only $c .9 \%$ in the Afrotropics, see Keast 1990). This low $\beta$ diversity seems to be accompanied by a low $\alpha$-diversity within African forest types (see Amadon 1973, Karr 1976). 


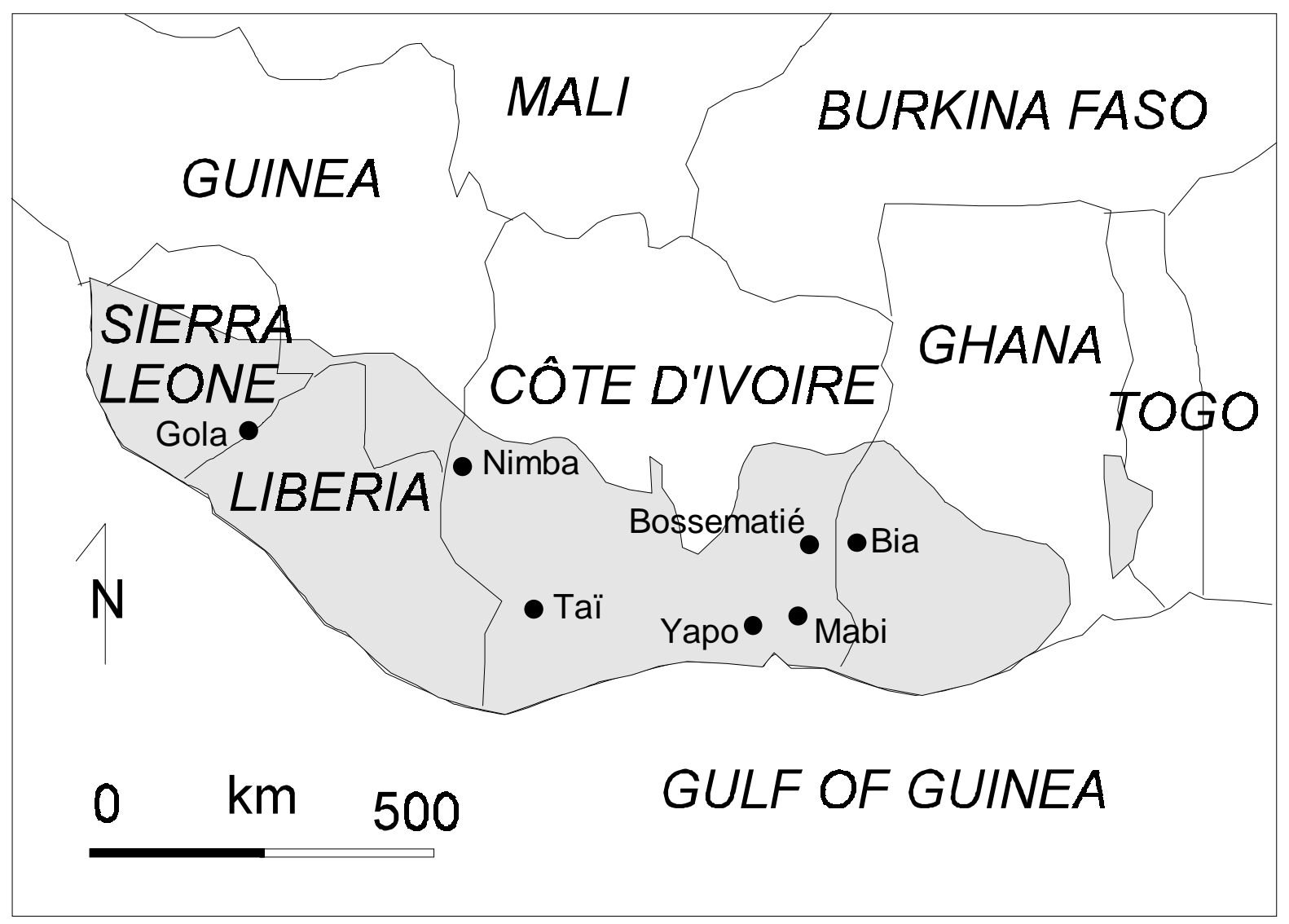

Fig. 1: Original distribution of humid tropical forest in Upper Guinea (from White 1979, Hall \& Swaine 1981) and situation of localities mentioned in the text (dots).

Considering more in detail the biology of the species, there also seem to be fewer specialisations in food and foraging techniques in Africa than in the Neotropics (Karr 1976). African forests only contain few species of specialised bark gleaning, hover-gleaning and sallying insectivores, groups with considerable radiation in the Neotropics (Erard 1989). Many African species (e.g. bulbuls, forest weavers, drongoes) are able to use these feeding behaviours as part of a whole repertoire of techniques. In addition, Neotropical hummingbirds posses more co-evolved associations than their forest relatives in Africa (Stiles \& Wolf 1970, Wolf \& Hainsworth 1971). Range and diversity of body sizes seems to be higher as well in Neotropical forests (Karr 1976). The generally low generic and familial diversity and relatively high taxonomical richness of groups such as phasianids, kingfishers, barbets and the paucity of parrots and trogons are other characteristics of African rainforests (Amadon 1973, Karr \& James 1975, Karr 1976).

The taxonomical and ecological features of the (West-)African rainforest biota should be interpreted in the light of the now widely accepted repeated Pleistocene reductions in forest cover and possibly the distinct history of human influences (Sowunmi 1986, Fjeldså pers. comm., Danielsen 1997), which probably caused large-scale exterminations (already recognised by Moreau 1966, Hamilton 1981). Species richness in a given habitat is considered being more related to ecological factors such as current vegetation productivity (Waide et al. 1999) and habitat complexity (Pearson 1975, Fjeldså 1997), but historical factors causing extinctions and/or isolation of populations (see latest review on numbers and spatial extents of Pleistocene 
refuges by Haffer 1997) also shape animal communities and numbers of coexisting species. The comparatively low degree of Upper Guinean endemism and the predominance of widespread old taxa are in line with palaeo-climatological findings (see discussion of eco-climatologically stable areas in Fjeldså 1995). Survival of old and evolution of new species during the Pleistocene mainly occurred in montane regions (see Roy 1997), which are few and small in western West Africa, unlike as e.g. in the East African highlands (Louette 1999). Although there are not many studies, there is indeed evidence - at least from those sites and taxa under study - that the African forest fauna and flora was more diverse c. 3 million years B.P. (Bonnefille \& Letouzey 1976, Williamson 1985). For the past 40,000 years, there is a better understanding of forest reduction processes. Forest reduction was undoubtedly largest at 18,000 B.P., when Upper Guinean forests were seemingly reduced to two single areas (Sierra Leone/Liberia and eastern Côte d'Ivoire/West Ghana, see Hamilton 1988). After all, it seems evident that on the comparatively dry African continent, savannah-forest-dynamical processes played an important role in the evolution of Africa's forest ecosystems.

\subsection{Status of Upper Guinean forests and possible threats to the avifauna}

\section{Deforestation}

Within the Upper Guinean region and even worldwide, Côte d'Ivoire has experienced the most rapid rate of deforestation (Gillis 1988, cited in Sayer et al. 1992). The southern third of the country was once almost entirely forested, but there is now hardly any natural, unmodified forest vegetation left. The moist forest zone (once covered by evergreen and semi-deciduous forest) of Côte d'Ivoire is estimated to have been about 132,000 sq. km, and by 1987 only some 22,000 sq. $\mathrm{km}$ or $17 \%$ remained (Sayer et al. 1992). There are 147 forest reserves (Forêts Classées) in Côte d'Ivoire, but due to a lack in efficient protection against agricultural encroachment, productive timber stands were thought to occupy only $15,000 \mathrm{sq}$. km, (FAO 1988, cited in Sayer et al. 1992). Most forest reserves (Forêts Classées) still covered by forest are severely over-logged, isolated fragments of variable size, mostly with a surface well below 200 sq. km (maps of SODEFOR 1996, WWF 2000). National Parks and other conservation areas in the forest zone cover about 5,000 sq. km, but are also under severe human pressure and need more efficient protection and management.

\section{Hunting}

In Côte d'Ivoire, hunting was officially closed in 1974 by a presidential order, but hunting activities are still widespread and include protected areas. As in Ghana (Holbech 1996), most farmers in eastern Côte d'Ivoire are part time hunters, activities ranging from small boys using dogs and wire-snares for catching smaller game, to semi-professional hunters using more time on hunting and trapping than land cultivation. Real professional hunters are mainly found in remote and unaccessible forest areas rich in large game, but they use Forêts Classées as well. Bush-meat is preferred to domestic meat, and a wide range of mammals, birds and reptiles are commonly exploited as source of protein (Martin 1989, Caspary 1997). The economical value of the bush-meat trade is high, even for rural people, since other sources of meat are limited (Caspary 1991). Among the birds hunted, especially Ceratogymna hornbills are seriously affected and their lack in certain areas is probably due to extreme hunting pressure (Holbech 
1996, Gatter 1998). Also densities of the large Great Blue Turaco Corythaeola cristata were found being depressed by hunting (Holbech 1996, Bamba 1999).

\section{Forest management}

The history of deforestation in Côte d'Ivoire may lead to the conclusion that recent and future protection of Forêts Classées is and will be based on the country's economical interest in the production of commercial timber. Many ideas have been developed on the way to reach and maintain sustainable yields in the mostly degraded forest areas by natural forest management (Parren \& de Graaf 1995). One technique increasingly used in Côte d'Ivoire is liberation thinning, carried out to improve the growth of commercial timber species (Wöll 1986, cited in Parren \& de Graaf 1995). It has been shown that this method enhances increment by $>30 \%$ in trees of certain diameter classes (Fickinger pers. comm.), which is an important argument in the economics of restoration programs. Therefore, liberation thinning is included in management plans of Forêts Classées in south-east Côte d'Ivoire and it is very likely that this technique will be used over large areas of logged-over forests in Côte d'Ivoire (SODEFOR 1994). The technique implies the freeing of individual trees from competition by increasing the exposure of their crowns to light, including climber cutting (see chapter 4.4). It is only applied in areas with a sufficient density of the regenerating tree cohort, but this can be the case even in heavily exploited forest. Trees are not directly felled to avoid initial damage, but instead, devitalised by intersecting their cambium. The average basal area killed by this treatment has been estimated at $1.5 \mathrm{~m}^{2} /$ ha representing about $10 \%$ of the total basal area in heavily exploited forest (Wöll 1991). A major objective is not to suppress the basal area below $50 \%$ of the original primary forest condition (Wöll 1991), but it can be very near to that limit in some areas, (e.g. in Bossematié Forest, Wöll 1991, Parren \& de Graaf 1995). Although liberation thinning only kills a relatively minor proportion of the existing basal area, the operation changes vertical vegetation cover significantly by reducing foliage in the middle and increasing foliage in the lower strata of the forest (Bamba 1999) which can be explained by more light penetrating the understorey through defoliated crowns and an increased rate of treefalls. The effects of the treatment on the forest fauna have not yet been studied.

\section{Species actually considered as threatened in Côte d'Ivoire}

19 bird species of conservation concern are known from Côte d'Ivoire, of which 3, Circus macrourus (NT), Falco naumanni (Vu) and Gallinago media (NT), are rare migrants from the Palaearctic (Fishpool in prep.). The remaining are all forest or forest edge species, two of which are considered being Endangered: Scotopelia ussheri (Strigidae) and Malimbus ballmanni (Ploceidae); eight are Vulnerable: Agelastes meleagrides (Phasianidae), Campephaga lobata (Campephagidae), Bleda eximia, Criniger olivaceus (both Pycnonotidae), Picathartes gymnocephalus (Picathartidae), Prinia leontica, Bathmocercus cerviniventris (Sylviidae) and Melaenornis annamarulae (Muscicapidae); the other six are Near Threatened: Ceratogymna cylindricus, C. elata (Bucerotidae), Phyllastrephus baumanni (Pycnonotidae), Malaconotus lagdeni (Malaconotidae), Illadopsis rufescens (Timaliidae) and Lamprotornis cupreocauda (Sturnidae) (Stattersfield et al. 1998). Fourteen of the fifteen restricted-range species of the Upper Guinean forest EBA occur in Côte d'Ivoire. Of these, thirteen are also species of conservation concern, only one species, Apalis sharpei, seems not to be under threat at present (Stattersfield et al. 1998). 


\section{Objectives and hypotheses}

\section{Current ecological research}

Because of palaeo-climatological peculiarities of the different continents, Danielsen (1997) postulates that the African forest birds might be much less sensitive to logging operations and/or forest fragmentation than the forest avifauna of South East Asia or South Central America. Danielsen's (1997) conclusion has only been supported by very few African studies, which were difficult to compare due to different logging techniques and different census methods. However, quantitative studies in Ghana's forest reserves (Holbech 1992, 1996) did at least not falsify Danielsen's hypothesis. Species richness and diversity of forest avifauna seemed unaffected by logging per se, but more important in terms of species loss was fragmentation (Holbech 1996). Forest reserves in Ghana of less than 50 sq. km size did loose many forest species irrespective of logging. Holbech's (1996) study was carried out on a large scale and, as many reserves were studied, it was based on relative abundance data (encounter and capture rates) and did not deal with particular management techniques. Relevant studies in Africa concerned with logging and bird faunas underline the necessity to focus on population data, bird behaviour, and population dynamics rather than to rely on species richness, diversity and relative abundance data only (e.g. Dranzoa 1998). Gartshore et al. (1995) similarly emphasises the importance of further ecological studies in this respect. Many forest bird species may be relatively common in secondary habitats such as tree plantations, but the role of these habitats for population dynamics remains largely unknown. Another reason, for impact assessments in forest reserves in Côte d'Ivoire is the overall condition of its Forêts Classées: Whereas in Ghana's forest reserves logging was moderate (1-2 trees/ha) and felling cycles were adapted to the regeneration potential of stands, there was no management attempting to obtain sustainable yields of trees in Côte d'Ivoire in the past (Sayer et al. 1992). Consequently, many Forêts Classées experienced heavy overexploitation.

As mentioned above, there is only a minor understanding of the consequences of the drastic recent ecological changes in the Upper Guinean region, and more information about the effects on biological diversity in this region is highly needed. Only in recent times, projects started to document the ecological status of forest reserves and to monitor long-term effects (e.g. Mühlenberg et al. 1995, Hoppe-Dominik 1999, Mühlenberg et al. 1999, Waltert 1999). In order to involve the local communities directly in conservation issues and to guarantee a longterm supervision of the areas, the organisation of monitoring programs is increasingly community-based. In such programs the numbers of indicator species are limited and adequate methods are still to be developed (Waitkuwait 1992, Mühlenberg et al. 1995, Mühlenberg et al. 1999). Researchers are faced by many methodological problems concerning density estimation (e.g. in duiker censuses, see Struhsaker 1997, Nett 1999). Therefore, supplementary short-term studies are highly valuable in providing cross-reference data for comparison. 


\section{Objectives}

This study has the following objectives:

- To document the structure of the vegetation mosaic in a logged-over forest and to assess the impact of forest management on its composition;

- To document the diversity, composition and structure of the forest bird community in a (heavily) logged-over forest after major deforestation in Côte d'Ivoire;

- To assess the impact of the forest management, especially the establishment of tree plantations and liberation thinning compartments on the rainforest birds;

- To provide baseline information, especially density estimates of forest birds for an evaluation of their conservation status and for cross-referencing with data from regular monitoring.

\section{Hypotheses:}

The principal hypotheses of this study were:

1. Bird species composition, diversity, and abundance structure in the heavily degraded Bossematié Forest in south-east Côte d'Ivoire should differ significantly from primary forests and from large, moderately disturbed forest reserves. It is, however, possible that some forest species can persist in the patchy mosaic of small, closed forest habitats (Johns 1996), but large species such as hornbills might need larger forest areas when disturbance has been high (Johns 1987, Kavanagh \& Bamkin 1995, O’Brien \& Kinnaird 1996). Due to high habitat heterogeneity created by heavy logging, overall species richness might still be high in degraded forest (Yahner 1988), but due to the extreme ecological changes, some forest specialists, especially understorey insectivores (Thiollay 1992) and species with restricted geographical ranges (Kattan 1992, Marsden 1998) might be extinct.

2. It has been shown that tropical lowland forest bird communities can be highly diverse and equitability in abundance between species can be extremely high (Terborgh et al. 1990, Thiollay 1994b). Abundance distribution in degraded forest, however, should follow logseries more than log-normal or broken-stick models (relationships between disturbance and abundance distribution e.g. in Johns 1992, Herremans 1995).

3. In an ecologically complex primary forest, spot-diversity (on a few hectares) is very high due to the year-round availability of major resources (Terborgh et al. 1990). In a degraded forest, this high alpha-diversity should be much reduced.

4. The bird community in the heavily logged forest should be dominated by geographically widespread species with low habitat specificity (Kattan 1992). Due to the predominance of productive vegetation layers near the ground, species with highest densities are found among understorey species. In general, less specialised species, e.g. with mixed diets, are expected to reach high densities.

5. In the Neotropics, obligate members of mixed foraging flocks are uncommon in logged forest (Thiollay 1992, 1994a). This should be the case also in obligately flocking African species in the Bossematie Forest. There, the most frequent members should be nonobligately flocking species. In contrast to undisturbed communities, associations between birds and other vertebrates (primates or larger mammals) should be a rare phenomenon. 
6. Liberation thinning produces a shift in the vegetation mosaic of the heavily logged forest, creating more gaps and reducing mature forest patches by increased treefall rates. Forest management such as liberation thinning and plantation management affects species composition and abundance in the degraded forest. Species with restricted ranges, and specialised species such as large understorey insectvores should have higher abundances in less disturbed forest compartments.

7. In view of source-sink population theories (Pulliam et al. 1992, Dias 1996), low recapture rates of bird species can indicate differences in habitat quality between logged and unlogged forests, even when no apparent differences are found in relative abundances (Uganda, see Dranzoa 1998). Lower recapture rates in more disturbed areas of the study plot can can also be expected from capture-recapture data (Winker et al. 1995.). 


\section{Study area}

The Bossematié area, as shown in Fig. 2, covers an appr. surface of 640 sq. km and includes two Forêts Classées (classified as government's property), the Forêt Classée de la Beki (Beki Forest), where no data was recorded, and the Forêt Classée de la Bossematié (Bossematié Forest). Forests in eastern Côte d'Ivoire are now reduced to seven Forêts Classées in total covering 188,880 ha. The essential function of Forêts Classées is to satisfy the country's industrial and traditional wood requirements. However, a co-operation between the forest authority SODEFOR and the German aid agency GTZ (since 1990) attempts to manage all forests as "natural" forests (see above) and to maintain species diversity. The Bossematié Forest is a typical example of an overexploited and degraded forest remnant in Côte d'Ivoire. Its condition is representative for the prevailing situation in most Forêts Classées after the phase of deforestation and exploitation in Côte d'Ivoire in the past decade (Parren \& de Graaf 1995). The $216 \mathrm{sq}$. $\mathrm{km}$ forest is located $40 \mathrm{~km}$ south of Abengourou $\left(6^{\circ} 35^{\prime}-6^{\circ} 20^{\prime} \mathrm{N}\right.$ and $\left.3^{\circ} 35^{`}-3^{\circ} 20^{\circ} \mathrm{W}\right)$. To the north, a six km strip of cultivated land separates the Bossematie from the even more degraded (Nett 1999) Beki Forest. To the east it is bordered by the Abengourou-Bettié road, to the south by the Comoe River and to the west by the small Bossematié River. Several villages are situated in its immediate vicinity and the forest block is totally surrounded by farmland (Fig. 2). The area has an altitude of $140-240 \mathrm{~m}$ and is slightly hilly with humid valleys, dry ridges, no permanent water but several small streams in the rainy season. 


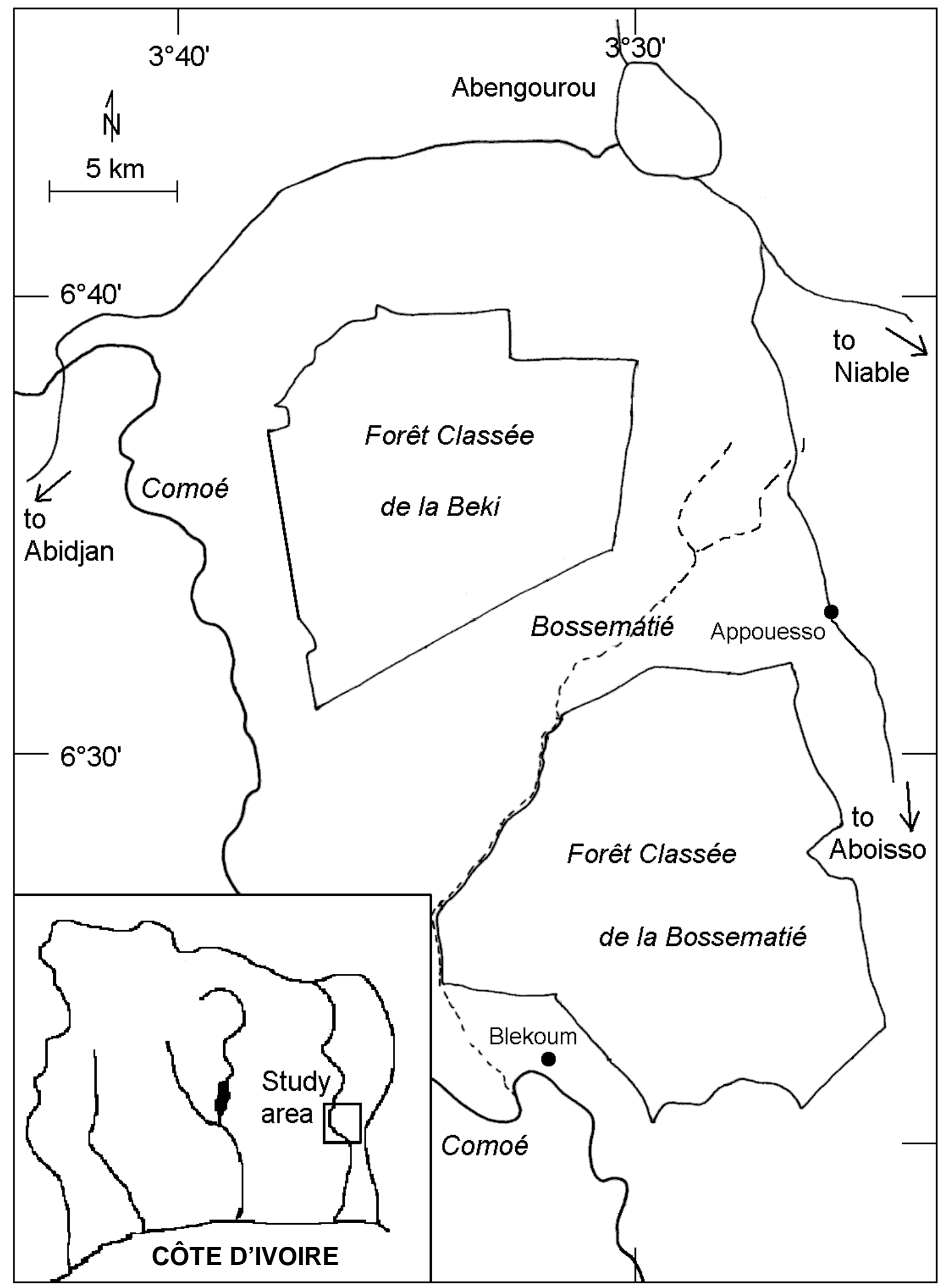

Fig. 2: Côte d'Ivoire and location of the Bossematié area, including the Forêt Classée de la Bossematié and the Forêt Classée de la Beki. 


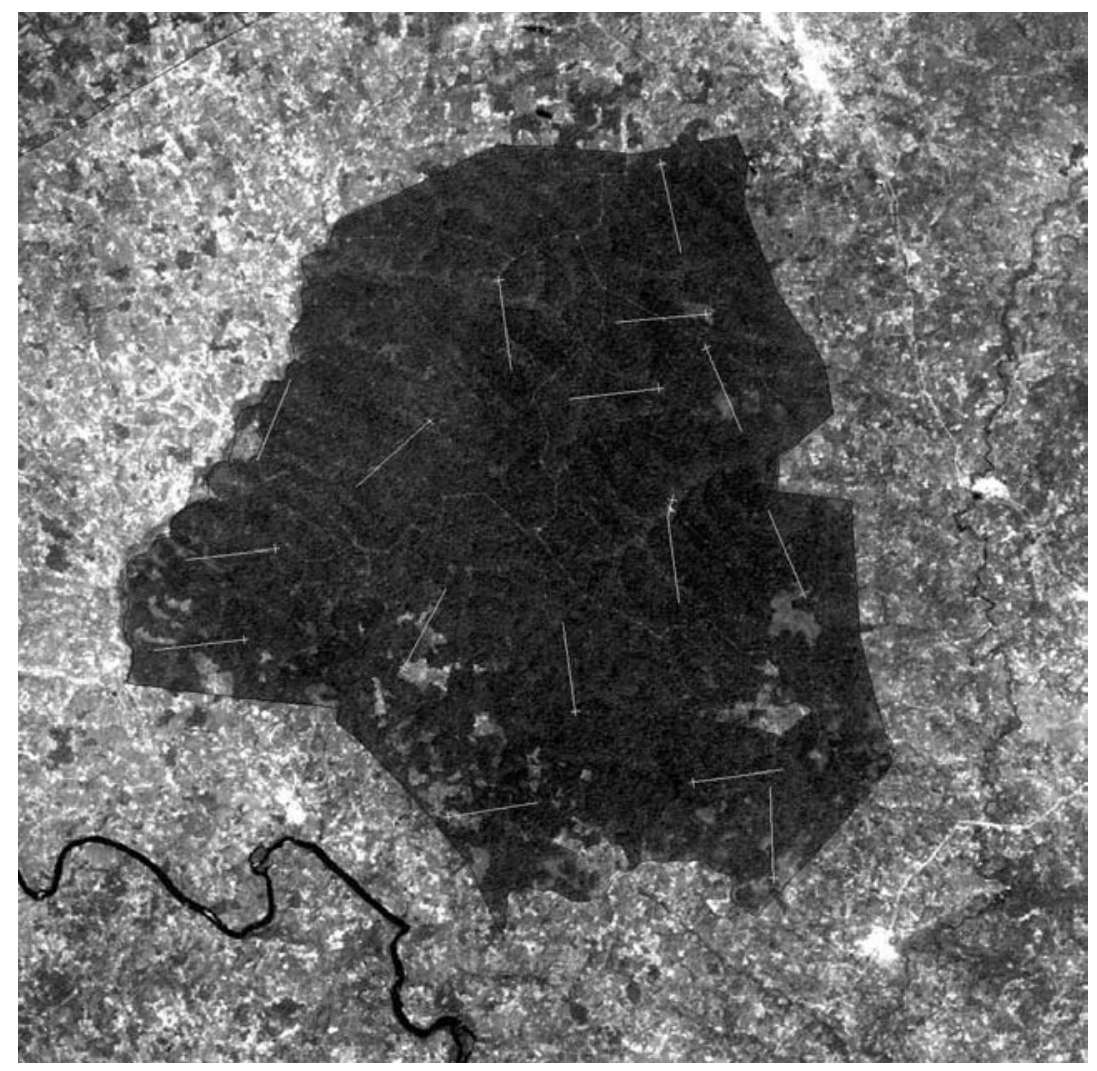

Fig. 3: Satellite image of the

Forêt Classée de la

Bossematié from 1999 (with

kind permission of

SODEFOR/GTZ, Centre

Abengourou, prepared by

Martin Schweter). The pale

patches constitute abandoned

cocoa/banana plantations

now covered by mono-

dominant tree plantations.

White lines indicate the

location of sixteen permanent

$2 \mathbf{k m}$ transects established for

community-based vertebrate

monitoring (Waitkuwait

1992, Mühlenberg et al.

1996).

\subsection{Geology, climate and soils}

Geologically, most of Côte d'Ivoire including the Bossematié area is characterised by flysch and archaeozoic migmatites (Buffard-Morel et al. 1979, cited in Hetzel 1998). Flysh is mainly composed of greywacke and shist, deposited under sea level during the Eburnéene orogeny (2.300 to 1.500 Mio. yrs B.P.). The bedrock for soil development is mainly formed by gneiss, itabirits, shists, mica-shists and greywacke, but except from quartz residues and debris (laterite crusts) weathering has not left much near the surface (Hetzel 1998).

The climate of the Bossematié area is characterised by a long dry season from November till February with predominantly North Easterly "Harmattan" winds and a long rainy season between March and October with one peak in June (South West Monsoon) and a smaller one in October. The rainy season is usually interrupted by a short dry period of some weeks from the end of July until mid August (meteorological observation centre Abengourou, Hetzel 1998). The rainfall pattern in 1996 differed somewhat from the long-term average in having higher precipitation in February (107 mm, mean 1920-1994: 43mm) but lower precipitation around May/June and September (see Fig. 4). The mean annual precipitation in Abengourou between 1920 and 1994 is $1323 \mathrm{~mm}$ (Hetzel 1998). The comparison of rainfall data from the period 1920 - 1960 with the period 1961 - 1994, indicates an increase in rainfall variability after the deforestation period, resulting in longer periods without any rainfall during the months November to March (Hetzel 1998). 


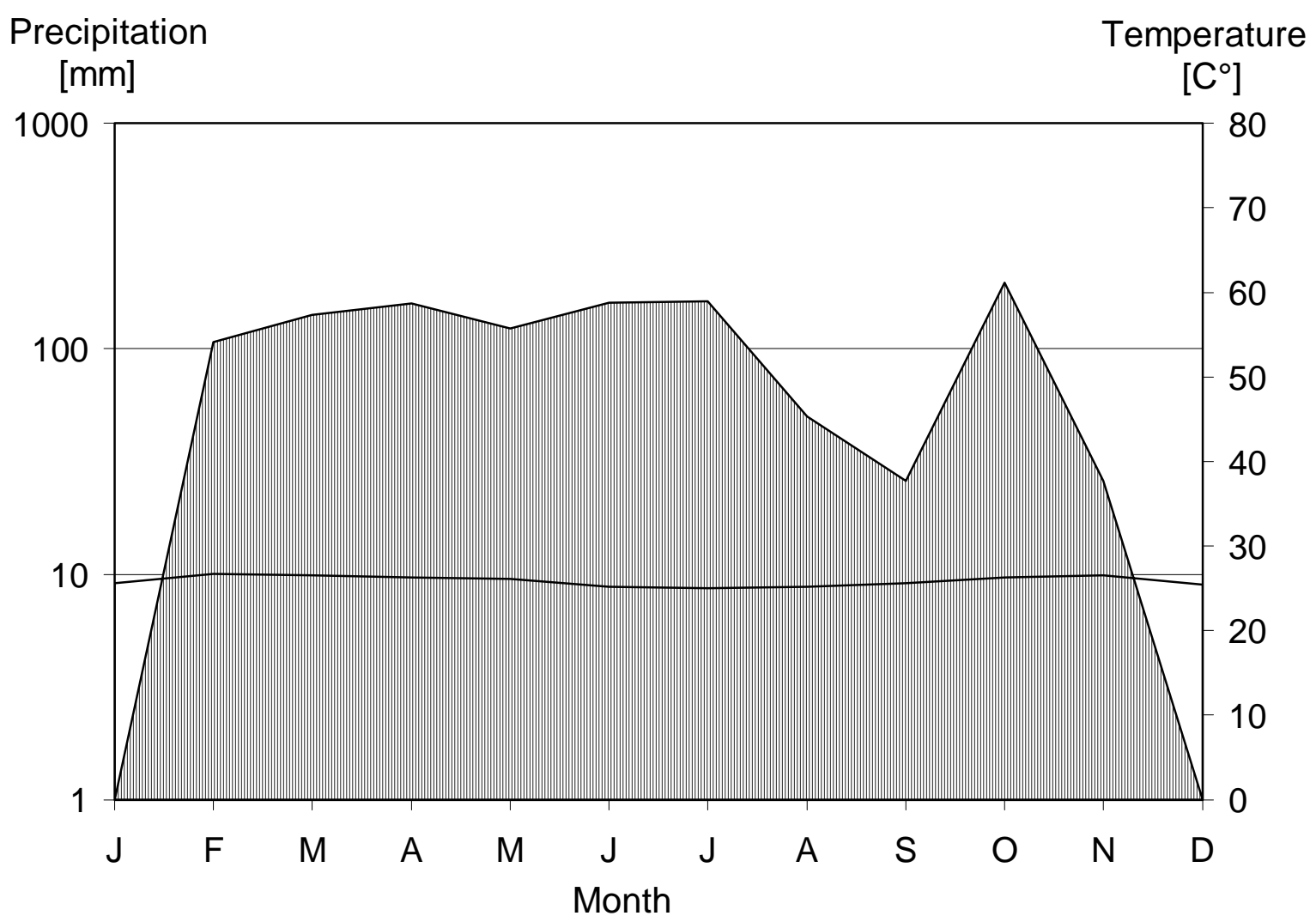

Fig. 4: Monthly precipitation and mean monthly air temperature in the Bossematié area in 1996 (data from cocoa plantation, Hetzel 1998)

The soils of the Bossematié area can be classified according to their physical characteristics and are narrowly associated with the topography of the area. Near watersheds and on the higher slopes, there is a predominance of ferralsols with a high clay content (25-50\%) in the subsoil and a humus-dependent but high nutrient content in the topsoil. Due to high compaction at depths below $30 \mathrm{~cm}$, the subsoil is free of roots. In addition, high water percolation due to high skeletal content decreases soil water during the dry season, which is relatively unfavourable for plant growth (Hetzel 1998). However, this soil type covers $c .67 \%$ of the total area of the Forêt Classée. At mid- and down-slope levels, cambisols with only a small amount of skeletal material are predominant. Due to the more balanced water storage capacity, this soil type is best suited for root formation in the area. Arenosols, characterised by a high sand content, and gleysols, are predominant in the valleys of the Bossematie area. Arenosols in the Forêt Classée show a considerable subsoil compaction due to the heavy machinery used for timber extraction, but generally they show a good root formation when undisturbed (Hetzel 1998). The gleysols, characteristic for the valley bottoms, show a poor soil water percolation due to considerable amounts of kaolin and a limited capacity for root growth.

All soil types have their highest organic content in the humus topsoil, which is usually between 5 and $20 \mathrm{~cm}$ thick. This thin layer is most important for the storage of nutrients due to a high 
cation exchange capacity. In comparison with other investigated sites of the inner tropics, the Bossematié soils seem to posses good nutrient reserves (Gerold 1995). Hetzel (1998) found a particularly high Calcium and Magnesium content, probably due to input from Harmattan or Monsoon winds. Additional input of atmospheric Nitrogen is probably caused by slash-andburn activities from the surrounding areas. Although the nutrient balance seems to be favourable for timber production, Hetzel (1998) concluded that unsustainable harvesting exceeding levels of more than $1 \mathrm{~m}^{3} * \mathrm{ha}^{-1} *$ year ${ }^{-1}$ can result in severe imbalances in the water cycle which acts as important nutrient carrier. Heavy timber exploitation inside the Forêt Classée already lead to a gradation of the heliophilous pioneer Chromolaena odorata (Eupatorium odoratum, Asteraceae), and resulted in a severe decrease in macro-nutrients in the topsoil and limited light conditions for saplings of pioneer tree species (Michler 1994).

\subsection{Vegetation, logging history and mammal fauna}

The Bossematié Forest belongs to the moist semi-deciduous forest zone (Guillaumet \& Adjanohoun 1971, Hall \& Swaine 1976, 1981). In West Africa, this formation is characteristic for lowland areas with an annual precipitation between 1250 and $1500 \mathrm{~mm}$. Soils are comparatively richer than in the wetter areas along the coastline due to the only moderate rainfall and lower nutrient depletion. A high stock of commercial timber species such as Utile (Entandrophragma utile), African Mahogany (Khaya ivorensis) and Samba/Obeche (Triplochiton scleroxylon) is a major characteristic. The average tree species richness on 625 sq. m plots is 103 spp. (Hall \& Swaine 1976). A total of 200 to 500 other vascular plants can be found on one ha of forest (Swaine \& Hall 1986). Most characteristic tree species of the Bossematié Forest are Triplochiton scleroxylon and Celtis spp. in the northern part and Khaya ivorensis and Piptadeniastrum africanum in the South.

The forest has been selectively logged five or six times between the early 1960s and 1990 . Timber exploitation stopped in 1990. Existing banana and cocoa plantations were abandoned at the beginning of the project in 1990. The upper storey of the forest is very open with less than eight stems over $60 \mathrm{~cm}$ diameter at breast height (dbh) per ha and a corresponding crown projection of less than $20-30 \%$ of the total surface (Wöll 1992). The valleys have a very open character and differ from the hills in having the understorey largely dominated by the aggressive introduced herb Chromolaena odorata (see above) and a less well developed midstorey. However, the drier hills are also characterised by a dense understorey under an open midstorey and canopy. Many clearings contribute to this open character.

The Bossematié Forest forms part of the proposed trans-national Bia-Bossematié network area, containing the six areas in eastern Côte d'Ivoire/western Ghana where the African Forest Elephant Loxodonta africana cyclotis still occurs (Parren \& de Graaf 1995). In addition to the Forest Elephant Loxodonta africana cyclotis, the mammal fauna includes the Chimpanzee Pan troglodytes verus. However, it is likely that only two of the primate species, the guenons Cercopithecus campbelli and C. petaurista live in viable populations (McGraw et al. 1998). A 
major threat to larger animals is poaching which had been reduced in the first years of the project, but has since increased again and still is high. Both species are encountered frequently.

\subsection{Seasonality of insect abundance}

Arthropods comprise a major food resource for birds and seasonal changes in food availability constitute a trigger in seasonal life cycle patterns such as breeding, moult or migratory behaviour. Seasonal changes might therefore also occur in general avifaunal composition or abundances of certain bird species in the Bossematié area. To explain possible differences in avifaunal data between sampling periods, own data on seasonal differences in insect abundance in the Bossematié Forest has been collected. Insect numbers were studied using a malaise trap (see Mühlenberg 1989) installed in the understorey of the Bossematié Forest. The trap has been operated between October 1996 and September 1997 and was emptied once a week. Specimens were trapped and stored in $70 \%$ alcohol.

Most abundant in the samples were arthropods of 1-5 mm size. Specimens of this size class were not determined taxonomically. Considerable numbers were captured in all months, but an increase was visible during the onset of the rains in March 1996 to decrease again in June. The numbers stayed surprisingly low during the second rainfall peak of the rainy season from July to September.

Insects with a body length longer than $5 \mathrm{~mm}$ were measured and identified to family or at least to order level. Occasionally invading Army Ants were excluded from the analysis. The most abundant arthropods $>5 \mathrm{~mm}$ were flies and mosquitoes (Diptera). There was a correlation between the abundance of 5-10mm Diptera and the average monthly rainfall (see Fig. 5). Numbers peaked together with the highest rainfall peak in April/May. However, numbers did not increase again during the September/October rainfall peak. The second most abundant insect group $>5 \mathrm{~mm}$ were small moths (Lepidoptera), most of them belonging to the typically nocturnal families Pyralidae and Noctuidae. This group showed a similar seasonal pattern, but the peak was already reached in February and March, two months before the rains started. 

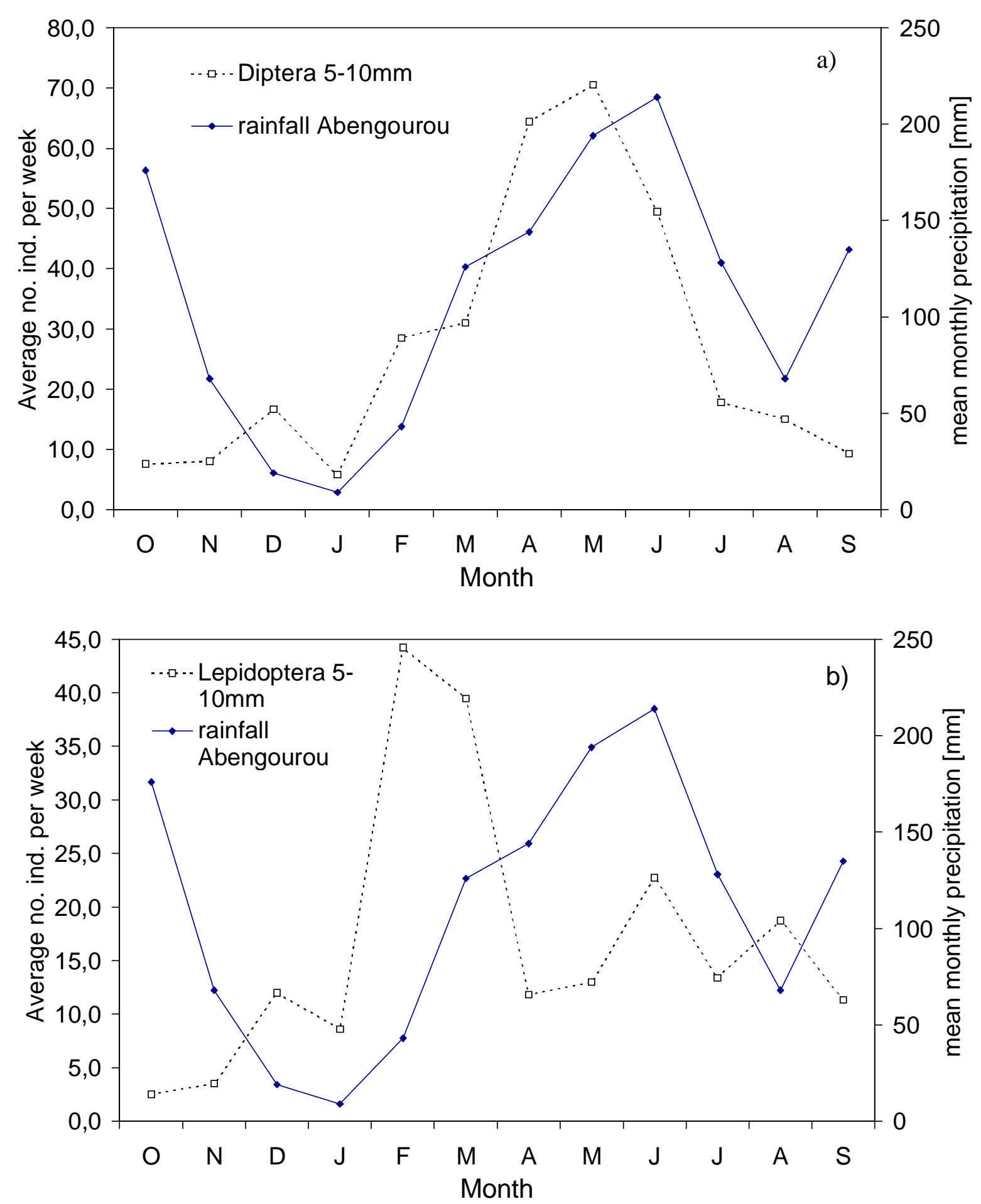

Fig. 5: Mean weekly numbers of Diptera (a) and Lepidoptera (b) individuals of 5-10mm body length in weekly Malaise trap samples (October 1996 to August 1997) and average monthly precipitation (data from meteorological observation centre Abengourou, cited in Hetzel 1998). 


\subsection{Management plan, silvicultural practices and biomonitoring}

Since 1990, the following management activities have been started: establishment of plantations of Samba Triplochiton scleroxylon and Fraké/Framiré Terminalia superbal ivorensis in former cocoa plantations and deforested areas (1076 ha), enrichment planting of potential crop trees in very degraded areas (2034 ha), and liberation thinning (9522 ha) (SODEFOR 1994).

Liberation thinning is carried out as described in chapter 2.2. In the Bossematie Forest, tree species playing a key role in the nourishment of various birds and mammals, e.g. primates and Forest Elephant Loxodonta africana, as well as rare and protected tree species are excluded from from the treatment (p. 61 in SODEFOR 1994). Three strict biological reserves were established within the forest borders, containing one third of the total forest area (7404 ha). In this area, no silvicultural practises will be carried out.

The planned management activities will be conducted until 2014. Controlled timber exploitation has been proposed for 2005-2014 on $c .4515$ ha with an intensity of 1.3 trees per ha (SODEFOR 1994). In order to monitor possible effects of management activities, an intensive program using $c$. 30 bird and 20 mammal species as bio-indicators has been started in 1992. The animals' densities are assessed from sixteen permanent $2-\mathrm{km}$ transects inside the forest (location in Fig. 3). Fieldwork is carried out by teams recruited from villagers around the forest, mainly experienced hunters. For more background information see Waitkuwait (1992), Mühlenberg et al. (1995), Mühlenberg et al. (1999).

\subsection{Study plot}

The study plot (Fig. 6) covers 110 ha and is situated in the northern half of the Bossematié Forest. The area has an altitude between 160 and $220 \mathrm{~m}$. A depression below $180 \mathrm{~m}$ runs through the northern half of the area in northwest-southeasterly direction. The study plot is part of the 1,982 ha experimental area, which has been established to monitor the effects of silvicultural treatments on the growth of principal timber species (description in Parren and De Graaf 1995). It includes 12.7 ha of a five years old tree plantation (mainly Terminalia spp., Triplochiton spp.), a 47.8 ha control compartment without silvicultural intervention (natural regeneration five years after last logging operations) and a disturbed compartment of 49.5 ha. This compartment includes a 32.1 ha area where liberation thinning has been carried out three years before the start of this study. The remaining 13.2 ha is situated in the depression, with very poor regeneration potential due to soil compaction from the use of heavy machinery during logging operations. There, no liberation operations have been carried out due to the low density of potential crop trees. The liberation thinning technique, together with the low tree cover characteristic of the swamp forest area are the two main factors determining the more disturbed character of the vegetation in this 49.5 ha compartment compared to the 47.8 ha control compartment. The different vegetation types on the plot are shown in Fig. 7 and appendix E. 
West to the control compartment and up to $500 \mathrm{~m}$ in distance from it, no forest management has been carried out. To the east of the study plot, adjacent to the liberation thinning area, liberation thinning continued for appr. $500 \mathrm{~m}$, but is restricted to a narrow $1 \mathrm{~km}$-strip. To the north, the forest plantation continues for some $100 \mathrm{~m}$, covering 25 ha in total. Further north or further south, no forest management has been carried out yet.

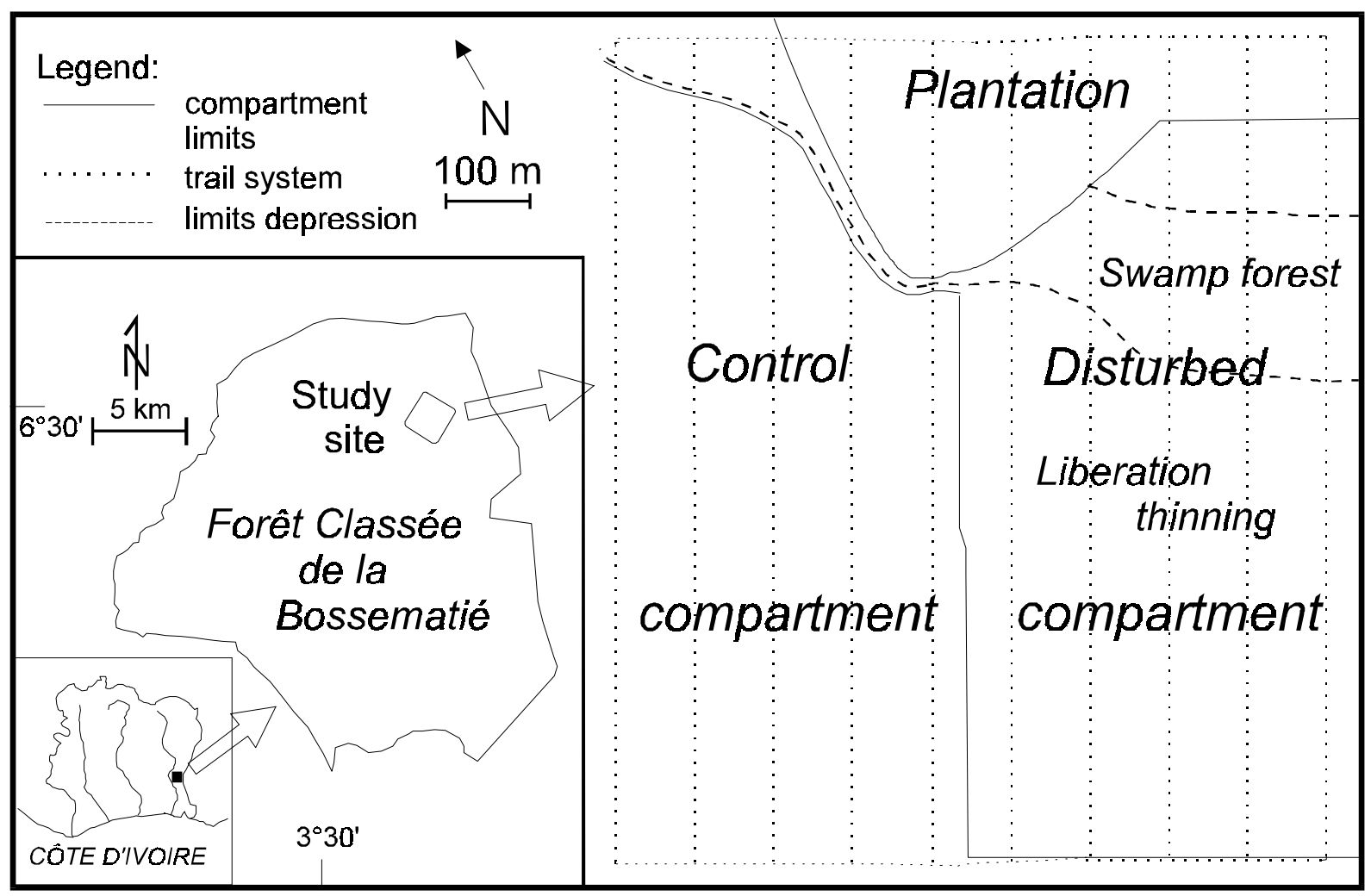

Fig. 6: Location and structure of the 110ha study plot.

Tab. 1: Overview of the principal compartments of the 110 ha study plot (see also Fig. 7, appendix E)

\begin{tabular}{lll}
\hline \hline Compartment & Sub-compartment & Vegetation type, management \\
\hline \hline Plantation (12.7 ha) & & mono-dominant tree plantation, five years old \\
\hline Disturbed (49.5 ha) & Swamp Forest (13.2 ha) & $\begin{array}{l}\text { swamp with poor tree cover, no silvicultural } \\
\text { intervention } \\
\end{array}$ \\
& Liberation thinning (36.3 ha) & $\begin{array}{l}\text { forest with liberation thinning (=selective } \\
\text { cleaning, or éclaircie sélective), three years old, } \\
\end{array}$ \\
& & disturbed by frequent treefalls \\
\hline Control (47.8 ha) & forest with natural regeneration, five years after \\
& & \\
\hline \hline $110 \mathrm{ha}$ & \\
\hline \hline
\end{tabular}


Height [m]

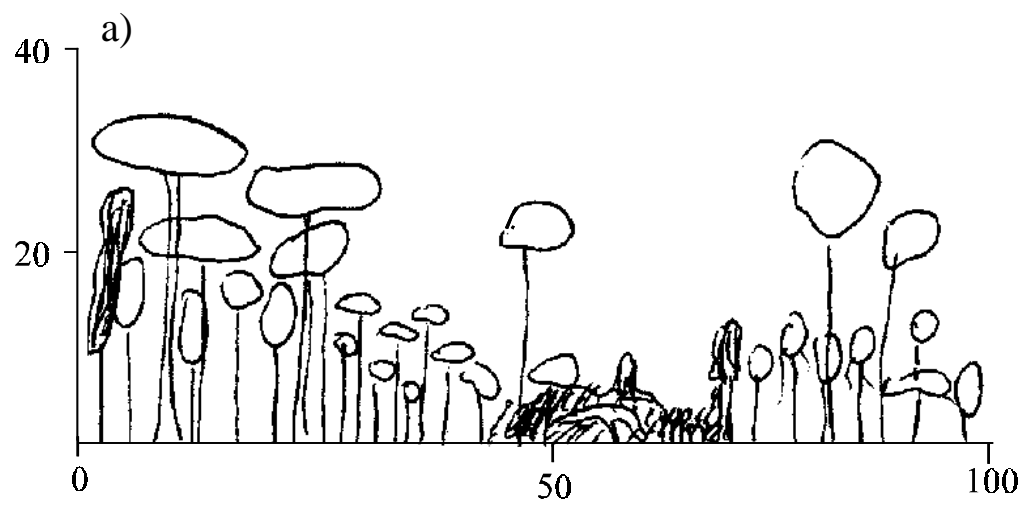

Fig. 7: The four principal vegetation types on the 110 ha study plot in the

Bossematié Forest, south-east Côte d'Ivoire. $100 \mathrm{~m}$ transect sections in a) control compartment (status of vegetation on slopes and near watersheds), b) liberation thinning area (status of slopes/watersheds, 3 years

b)

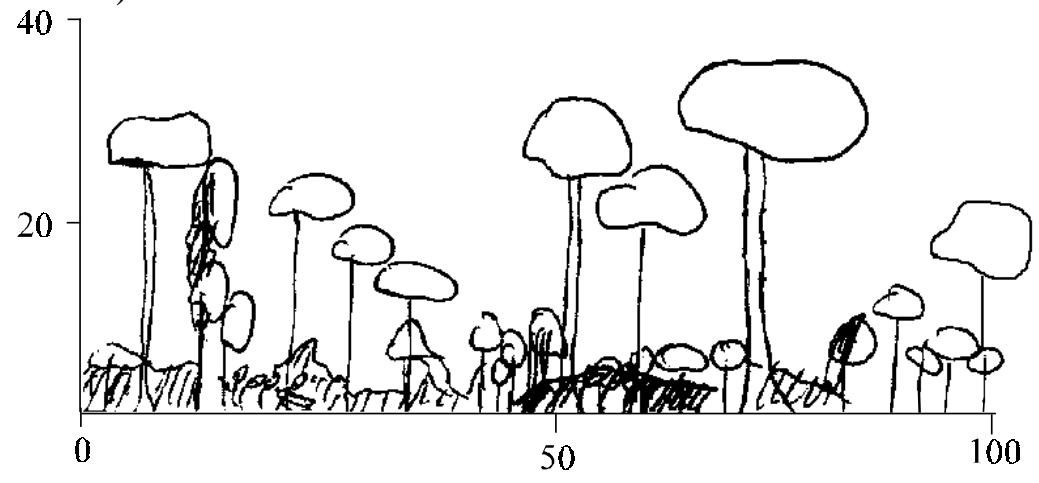
after treatment), c) swamp forest area (valley bottoms), and d) Terminalia plantation (at lower slope level, 5 years old).

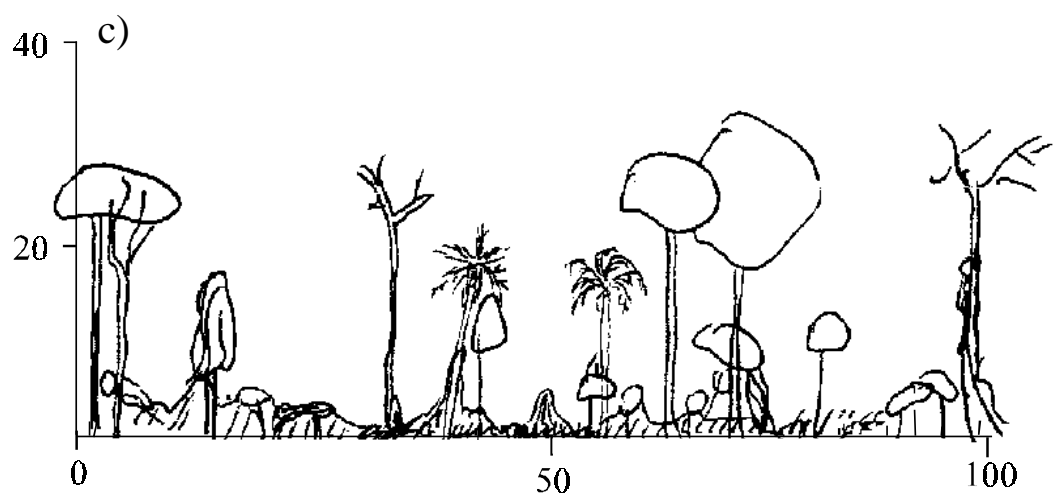

d)

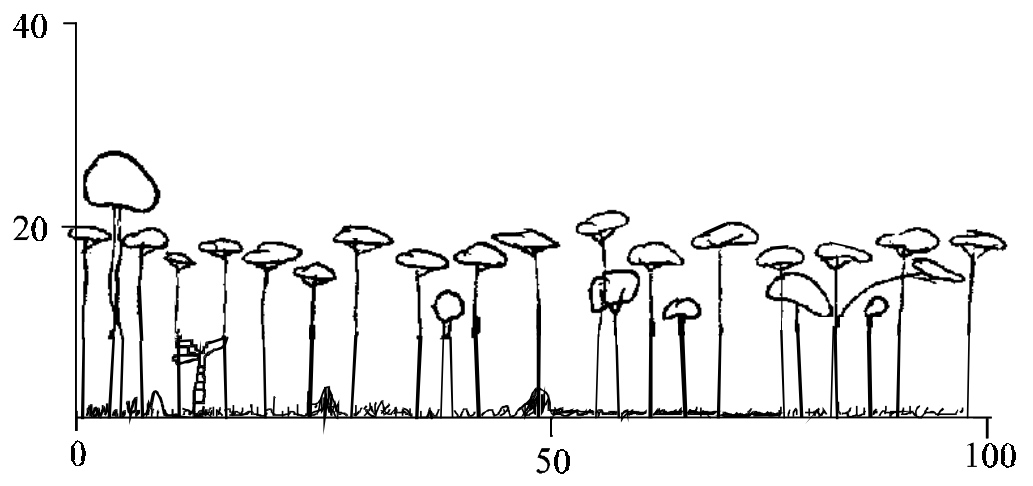

[m] 


\section{Methods}

\subsection{Analysis of the vegetation structure}

Within the study plot, the vegetation structure as been studied more in detail. The following vegetation parameters were recorded: overstorey tree size (OTS), being the average diameter $(\mathrm{cm})$ of the nearest overstorey tree (girth $>10 \mathrm{~cm}$ ), overstorey tree dispersion (OTD), being the average distance from the sampling point to the nearest overstorey tree (girth $>10 \mathrm{~cm}$ ) and understorey tree dispersion (UTD), being the average distance from the sampling point to the nearest understorey tree (girth $5-10 \mathrm{~cm}$ ). These parameters have been used to describe microhabitats of small mammals in tropical forests (e.g. Dueser \& Shugart 1978, Ganzhorn et al. 1990). One measurement was taken for each quarter around sampling points situated every $25 \mathrm{~m}$ along trails in the 110 ha study site. Medians from sampling points were calculated and compared between compartments using Mann-Whitney $U$-tests and the Kruskal-Wallis ANOVA. From the medians, the number of understorey and overstorey trees per ha was calculated for each vegetation type using the following formula (after Mueller-Dombois \& Ellenberg 1974):

$$
\begin{aligned}
& \text { Overstorey tree density }=\frac{\text { Area }\left(10,000 \mathrm{~m}^{2}\right)}{(\text { medianOTD }[\mathrm{m}])^{2}} \\
& \text { and } \\
& \text { Understorey tree density }=\frac{\text { Area }\left[10,000 \mathrm{~m}^{2}\right]}{(\text { medianUTD }[\mathrm{m}])^{2}}
\end{aligned}
$$

In the Bossematié Forest, logging operations created a heterogeneous small-scale mosaic of patches of different successional status. To document the overall status of the Forêt Classée and to document whether liberation thinning created a significantly higher proportion of young succession stages, a vegetation survey was conducted within the whole forest between December 1995 and January 1996. The sixteen permanent transects of the Forêt Classée and the parallel trails of the 110 ha plot were used. Assuming that succession is related to vegetational complexity, four succession stages have been differentiated (Fig. 8):

1. "Gap", according to Levey (1988) as a vertical hole in the vegetation down through all strata (no canopy), ground almost always covered by the heliophilous Chromolaena odorata;

2. "S1", with a single-layered canopy at low heights, dense foliage at eye level;

3. "S2", with a single layered canopy at low heights and sparser foliage at eye level;

4. "S3", with multi-layered canopy, and considerable amounts of foliage in all strata.

This classification proved to be easily applicable in other Forêts Classées (see Nett 1999) and similar techniques have been successfully applied in tropical forests (see Pearson 1975, or Holbech 1992). $50 \mathrm{~m}$-sections along the Bossematié transects (Fig. 3), and $25 \mathrm{~m}$-sections along trails of the study plot have been assigned to one of the four different succession classes. 
Proportions of each succession stage were calculated for each vegetation type on the plot and for the total sixteen transect lines of the Forêt Classée. To analyse the relationship between the morphological description and the measured parameters, averages of OTS, OTD and UTD were plotted against succession and tested with the Gamma rank correlation for multiple ties.

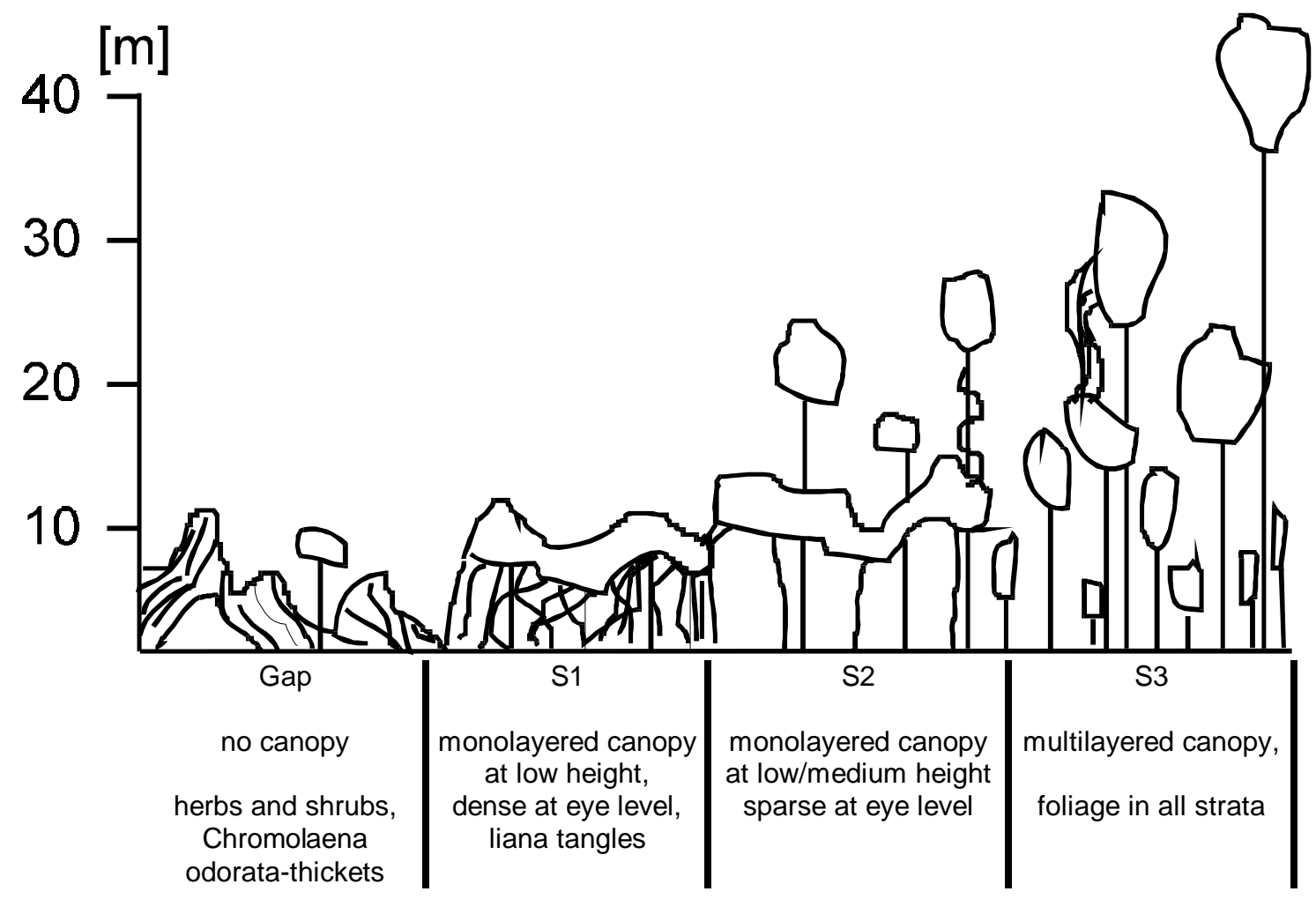

Fig. 8: Morphological classification system of succession stages based on structural characteristics of canopy and understorey (see text for details).

\subsection{Ornithological fieldwork}

In total, fieldwork was done in the Bossematié area, which includes the Forêt Classée and the surrounding farmland, but not the Beki Forest (appr. 640 sq. km as shown in Fig. 2), during thirteen months between April 1995 and August 1997. Observations were made at 52 days of the dry season (December 1995 - February 1996, December 1996), but 129 days were spend in the field during the wet season (April-July 1995, March 1996, September-October 1996, JuneAugust 1997). Birds were observed inside the Forêt Classée on 161 days and in the surrounding farmland on 38 days, see Waltert et al. 1999 and appendix A.

\subsubsection{Preliminary surveys}

Because adequate knowledge of bird behaviour and vocalisations is a pre-condition for successful studies on tropical avifaunas (e.g. Terborgh et al. 1990), the first six months (April July 1995 and December-January 1995/1996) may be regarded as an intensive preparatory phase. During this time, mist-netting and line transect censuses were undertaken in various 
parts of the Bossematié area and along the 16 permanent transects of the Forêt Classée (Fig. $3)$.

Species were identified using Serle et al. (1977) and Mackworth-Praed \& Grant (1970, 1973). In addition, information from Brown et al. (1982) Keith et al. (1992), Urban et al. (1986, 1997), Fry et al. (1988), and the publications of Fishpool et al. (1994a,b), Allport et al. (1996), Fishpool (1999) and Demey (in prep.) were used. Voices were learned with the help of Chappuis (1974a,b, 1975, 1978, 1979, 1985) and playback-experiments attracting shy and skulking species were carried out. Mist-netted species which could not be identified in the field were photographed and compared with skin collections at the Royal Museum of Central Africa at Tervuren, Belgium. Identifications were confirmed by M. Louette, R. Demey and L.D.C. Fishpool. Tape-recorded voices were kindly identified by C. Chappuis and R. Demey.

\subsubsection{Standardised mist-netting}

For several reasons, mist-netting is a major component of breeding bird censuses in tropical rainforest (Terborgh et al. 1990). It introduces the previously unfamiliar researcher to shy and skulking understorey species, it provides assessment of ecological density and allows to study population parameters. Furthermore it facilitates the comparison of data from different reasearchers, because the method is less observer-dependent than mapping by visual or acoustical means.

To reach a certain level of saturation and to improve the probability to obtain recaptures of individuals between sampling periods, mist-netting was restricted to two core areas of the study plot (as e.g. in Thiollay 1994b). The two vegetationally most distinct areas, the northern part of the control compartment and the most degraded part of the disturbed compartment, were selected. Mist-nets in the disturbed compartment included the swamp forest area and the adjacent part of the liberation thinning area (Fig. 9, Fig. 6). Successive mist-netting during a single sampling period covered approximately 32 ha of the study plot, 16 ha in each compartment. The procedure was carried out three times: at the end of the 1995/1996 dry season and during the wet seasons 1996 and 1997 (Tab. 2). A mist-net line (102 m) composed of seventeen six-meter, $19 \mathrm{~mm}$-mesh mist-nets was used to trap birds. This line was installed at sixteen locations during each sampling period, eight lying in each compartment (Fig. 9). One mist-net sample consisted of the birds trapped with this line during 10 daylight hrs (102 $\mathrm{m} \times 10$ hrs $=1020 \mathrm{mhrs}$ ). The sixteen $102 \mathrm{~m}$ locations were regularly spaced by the $100 \mathrm{~m}$-spaced trail system (Fig. 6). Mist-netting in the control compartment always preceded a similar effort (number of samples taken) in the disturbed compartment. The net line was installed by two persons keeping disturbance to a minimum. The setting procedure started at 13:00 and took two hrs with only slight deviations from this schedule. The mist-nets were kept open from 15:00 until 18:30, then put together to avoid entanglement of bats (Chiroptera) and opened the next day from 6:30 to 13:00, after which the line was removed. This relatively short period was chosen to produce only minimal levels of net shyness. Captured birds were ringed with uniquely numbered aluminium rings, flight feathers were checked for moult (scores from 0-5), reproductive condition (brood patch in sores from 1-5), sex and age (whenever possible) and 
standard measurements (wing and tail length; weight using $100 \mathrm{~g}$ PESOLA spring balance). Time and exact location (single six-meter net) of each capture were also noted.

Tab. 2: Distribution of standardised mist-netting activities in the 110 ha plot of the Bossematié Forest. Each date represents a single sample $(1020 \mathrm{mhrs})$. In each season, trapping was done at sixteen single locations, two additional samples (marked by asterisk) were taken at different locations but not included in the analysis.

\begin{tabular}{|c|c|c|c|c|c|c|c|}
\hline \multirow{3}{*}{$\begin{array}{l}\text { Year } \\
\text { Season } \\
\text { Month }\end{array}$} & \multicolumn{5}{|c|}{1996} & \multicolumn{2}{|c|}{1997} \\
\hline & \multicolumn{2}{|c|}{ Dry } & \multicolumn{2}{|c|}{ Wet } & \multirow{2}{*}{$\begin{array}{l}\text { Dry } \\
\text { Dec }\end{array}$} & \multicolumn{2}{|c|}{ Wet } \\
\hline & Feb & Mar & Sep & Oct & & Jul & Aug \\
\hline \multirow[t]{11}{*}{ Day } & 9 & 1 & 9 & 1 & $11^{*}$ & 21 & 1 \\
\hline & 11 & 18 & 10 & 2 & & 22 & 4 \\
\hline & 13 & 19 & 11 & 3 & & 23 & 7 \\
\hline & 16 & 20 & 13 & 4 & & 28 & 8 \\
\hline & 19 & 21 & 16 & 9 & & 29 & 11 \\
\hline & 20 & & 17 & $15^{*}$ & & 30 & 12 \\
\hline & 21 & & 19 & & & & 14 \\
\hline & 22 & & 20 & & & & 15 \\
\hline & 27 & & 26 & & & & 18 \\
\hline & 28 & & 27 & & & & 20 \\
\hline & 29 & & 28 & & & & \\
\hline \multirow{2}{*}{$\begin{array}{l}\text { Days per month } \\
\text { Days per season }\end{array}$} & 11 & 5 & 11 & 6 & 1 & 6 & 10 \\
\hline & \multicolumn{2}{|c|}{16} & \multicolumn{2}{|c|}{$16(17)$} & 1 & \multicolumn{2}{|c|}{16} \\
\hline Total & \multicolumn{5}{|c|}{48 (50) capture days } & & \\
\hline
\end{tabular}

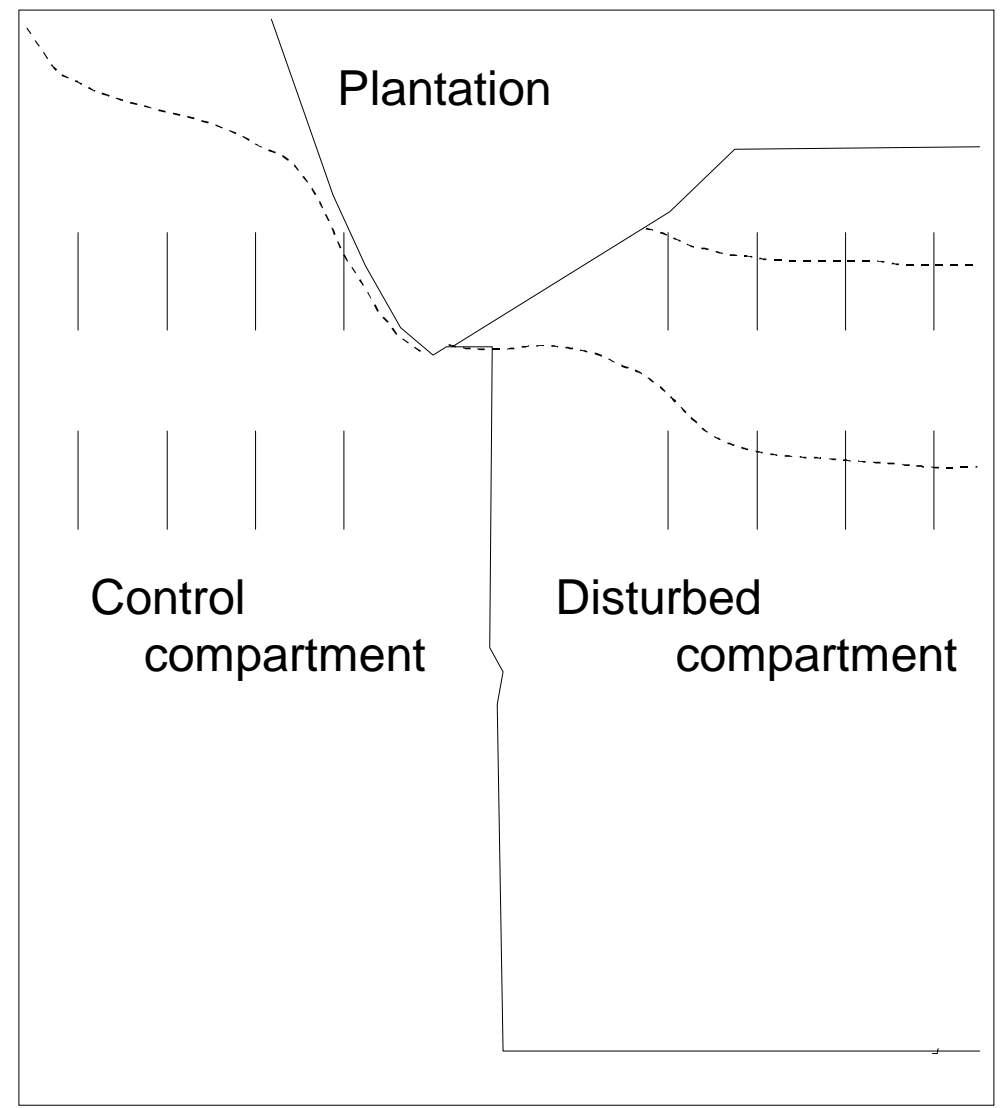

Fig. 9: Location of the sixteen sampling sites (vertical bars) in the control and the disturbed compartment, where mist-netting has been carried out using a 102 m mist-net line. 


\subsubsection{Spot-mapping}

In comparison with the temperate zone, birds of tropical forests have developed more complex breeding systems, more flexible territorial behaviour and often unknown or (seasonally or daily) limited activity periods (see Karr 1976, Terborgh et al. 1990). Therefore, adequate census methods and developed observer skills are needed to map tropical forest birds by visual and acoustical means. It has been shown that a lack of bird identification skills, limitation to one single methodology and inadequate plot sizes produce serious under-estimation of species richness and diversity (discussions e.g. in Terborgh 1990 or Thiollay 1994b). But compared to the Neotropics these problems seem to be of minor importance in Africa, where many rainforest species show territorial behavioural traits and are more easily and regularly detected by acoustical means than species with larger, ill-defined homeranges and more complex spacing systems (Karr 1976).

Spot mapping was only carried out at the end of the field work period when maximal skills for identifiying birds were attained. Because a sample plot of 110 ha could not be covered completely by one observer during one morning, the plot was divided into six separate sectors of 18.3 ha each (Fig. 10). One census of the complete plot was based on six consecutive visits. In this way, six complete censuses (A to F) were undertaken (36 separate visits). Each visit started at 6:00 hrs and was completed until 9:30 hrs. In each sector, the trail system was walked at a slow pace and all observations were mapped (1: 2000 scale). The observations made during the six successive visits were combined to produce a spot map for each single species and for each census. Observations along the borders of adjacent 18.3 ha sectors were only included on the census maps, when they were spaced by more than $50 \mathrm{~m}$. The spotmapping period ranged from 9 June to 21 August 1997.

In lowland primary forest in Peru (Terborgh et al. 1990), territorial maps were obtained from numerous field visits of different observers collecting ornithological data from different parts of a study plot (97 ha), using different methods and with a different state of knowledge. These differences were compensated by the comparatively long time-span during which the study was carried out. However, when focusing on habitat selection patterns, it seems more appropriate to use data from a single observer and to combine data from separate visits of several smaller adjacent sectors to one complete census (e.g. Thiollay 1994b). 


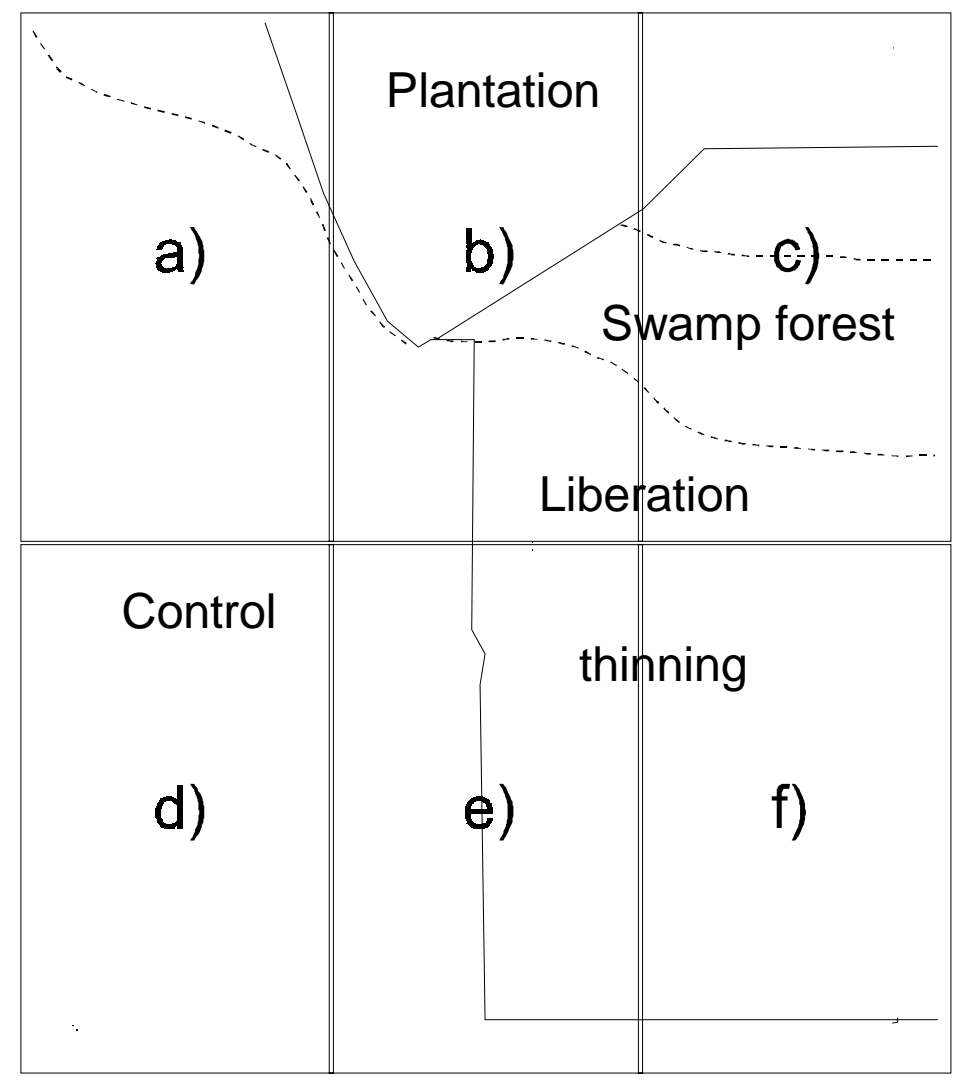

Fig. 10: Study plot showing the six 18.3 ha sectors (a to f), each one representing the sampling unit of a single visit. 


\subsection{Calculation methods and statistics}

\subsubsection{Abundance}

Species richness and diversity calculations were based on densities of the breeding population (number of social units or pairs). These were estimated either from the maximum (in shy and non-vocal species) or median (in vocally active and regularly singing species) numbers of singing/displaying individuals during one complete mapping census (see above). Compartments or sectors often only cover parts of the homeranges of species, especially of those of lower densities, and most likely not all species can be adequately assessed during each field visit because of temporal variability in territorial behaviour or weather conditions. Densities were calculated as "pairs" per 100 ha for the plot and as "pairs" per 10 ha for interspecific comparisons of habitat preferences between vegetation types (control, liberation thinning, swamp forest and plantation, see Tab. 1).

For certain species, mist-net data provide information for the assessment of "ecological" density, as not only territorial displaying but as well sub-ordinate ("underworld") individuals are recorded. However, neither all understorey nor midstorey and canopy species can be adequately assessed by mist-netting. Therefore, it is more correct to use pair (group) densities derived from counts, especially when interspecific comparisons are to be carried out. For some non-vocal species only recorded by mist-netting (e.g. woodpeckers, kingfishers), pair densities were estimated by combining mist-net data and biological information on social system, average group sizes and vertical stratification from the literature (Brown et al. 1982, Urban et al. 1986, 1997, Keith et al 1992, Fry et al. 1988, Gatter 1998).

An issue relevant for the calculation of densities is the arrangement of the trail system. A problem can arise if the distance between trails is too large for the detection of species with weak voices (e.g. in small species such as sunbirds or warblers). Especially small canopy species might then be seriously under-recorded. In this study, a trail system comparable to Terborgh et al. (1990) or Thiollay (1994b) was used to facilitate comparisons between studies. In these studies, a $100 \mathrm{~m}$ grid system of trails is considered being sufficient to detect all singing individuals of the majority of species.

\subsubsection{Calculation of community parameters}

\section{$(\alpha-)$ Diversity and species abundance models}

Diversity of the total community was calculated using various diversity indices. Indices were calculated for single samples (based on trapped or encountered individuals) and the total community. Calculations were carried out with the help of Colwell (1997) in which formulas from the following sources are used: Shannon-index $\left(\mathrm{H}_{\mathrm{s}}\right)$, Evenness $\left.\left(\mathrm{H}_{\mathrm{s}} / \mathrm{lnS}\right)\right)$, Simpson index (1/D) after Magurran (1988) and William's alpha after Fisher et al. (1943), cited in Magurran (1988). Berger Parker indices were calculated by hand using Magurran's (1988) formula. The 
underlying formulas, major assumptions and characteristics of the different indices used are presented in the following.

As a non-parametric index (no assumptions on the underlying species abundance distribution), Shannon index was calculated as

$$
H_{s}=-\sum_{i=1}^{S} p_{i} \ln p_{i}
$$

with the quantity $\mathrm{p}_{\mathrm{i}}$ being the proportion of individuals found in the $i$ th species. $\mathrm{p}_{\mathrm{i}}$ can be estimated from a sample as $n_{i} / N$, with $n_{i}$ the number of individuals of species $i$, and $N$ the total number of individuals. The main assumption in using the Shannon index is that randomness of the sample, e.g. no differential attraction of a species to a trap (such as moths to a light trap), must be given. Compared to other indices, Shannon has a moderate capacity to discriminate between communities and is mainly influenced by abundances of the medium abundant species (Magurran 1988).

The ratio of observed to maximum diversity can be taken as a measure of evenness. Evenness is calculated as

$$
\mathrm{E}=\mathrm{H}_{\mathrm{s}} / \mathrm{H}_{\max }=\mathrm{H}_{\mathrm{s}} / \ln \mathrm{S}
$$

with $\mathrm{H}_{\max }$ the "maximum diversity" (all species equally abundant). Evenness $\mathrm{E}$ is constrained between 0 and 1.0 providing better opportunities for comparisons. Whereas Shannon index is less influenced by dominance, the Simpson index is very sensitive to the abundance of the most common species. It gives the probability of any two individuals drawn at random from a finite community belonging to different species. It is calculated as:

$$
1 / D=\frac{1}{\sum\left(\frac{n_{i}\left(n_{i}-1\right)}{N(N-1)}\right)}
$$

The Berger Parker index is another simple dominance measure, expressing the proportional importance of the most abundant species:

$$
\mathrm{d}=\mathrm{N}_{\max } / \mathrm{N}
$$

where $\mathrm{N}_{\max }=$ the number of individuals in the most abundant species. In the reciprocal form, increasing values accompany an increase in diversity and an increase in dominance. The index is independent of the number of species (S), but influenced by sample size. 
As Berger Parker and Simpson are not sensitive to species richness, the log-series index $\alpha$ was also calculated. Together with $\mathrm{N}$ (total number of individuals), $\alpha$ is a major parameter in the description of a log-series distribution (see below). It is calculated as:

$$
\alpha=\frac{\mathrm{N}(1-\mathrm{x})}{\mathrm{x}}
$$

with $\mathrm{x}$ being an iterative solution of the formula

$$
S / N=(1-x) / x[-\ln (1-x)]
$$

and $\mathrm{S}=$ number of species. The $\alpha$ (log-series) index is not much dependent on sample size and possesses a good discrimination ability between communities.

The value of species-abundance models for applied ecological research is still subject of discussions (see Nummelin 1998, Basset et al. 1998, Watt 1998), but it has been generally accepted that, when adequately interpreted, they can be quite useful in the analysis of community structure patterns (Hill \& Hamer 1998).

The majority of natural communities display a log-normal distribution which is believed to indicate a large, mature and varied community (Magurran 1988). A log-normal distribution of relative abundance implies a concave (logarithmic)abundance-rank diagram for the "lower"ranking species (i.e. the most common ones) and a a convex curve for the "higher" ranking species. An extreme abundance form is the broken-stick abundance model, which reflects an even more equitable state being the biological correspondent of a uniform distribution. If a broken-stick distribution is found, there is incidence that an important ecological factor is shared more or less evenly between the species. For example, Thiollay (1994b) suggested predation to be likely responsible for the broken-stick distribution of bird species abundances in Amazonian rainforest. The log-series distribution is often visible in immature or stressed communities, dominated by one or a few ecological factors, but can also be due to small sample sizes. In a (logarithmic)abundance-rank diagram, a logarithmic series distribution implies a straight line except for the "lower" ranking species. Log-normal and Log-series models have also been used in palaeo-biology to describe instable evolutionary periods (Stenseth 1979).

To describe species abundance distributions of samples, species-abundance models were fitted to expected distributions (log-normal, log-series) by chi-square Goodness of fit tests. Expected distributions were calculated with the software LOGSERIE and LOGNORM, inserted in Krebs (1989).

\section{Estimation (extrapolation) of true species richness from samples and rarefaction}

As comprehensive sampling of species richness is difficult in rich tropical communities, statistical methods have been established to estimate total species richness from single samples and randomisation of species turnover between them (see Colwell \& Coddington 1994, 1995, Mawdsley 1996). For a research program on the arthropods of the La Selva forest, Costa Rica 
(Project ALAS), the calculation software EstimateS was developed by Colwell (1997). Here, Colwell's (1997) software version EstimateS 5.0.1 was used. The program allows to compute richness estimators (as well as indexes of diversity and species similarity, if requested) based on the successive pooling of data from single samples. It includes richness estimators from various authors (see Colwell \& Coddington 1994, Colwell 1997 and references therein). Extrapolations of species richness become more and more accurate with increasing numbers of samples, but can be already obtained for single sample such as the community of the 110 ha study plot. The main estimators used were Chao's method no. 1 ("Chao1", Chao 1984) and the derived abundance-based coverage richness estimator (ACE, Chao et al. 1993), both being based on functions of singletons and doubletons in the sample.

For reference, the respective formulas are added (from Colwell 1997). Chao 1 is calculated as

$$
\mathrm{S}_{\text {Chaol }}=\mathrm{S}_{\mathrm{obs}}+\frac{\mathrm{F}_{1}^{2}}{2 \mathrm{~F}_{2}}
$$

with $F_{i}$ the number of species that have exactly $i$ individuals when all samples are pooled $\left(F_{1}\right.$ is the frequency of singletons, $F_{2}$ the frequency of doubletons) and $S_{\mathrm{obs}}$ is the total number of species observed in all samples pooled. A standard deviation is computed with the variance estimator

$$
\operatorname{var}\left(S_{\text {Chao } 1}\right)=F_{2}\left(\frac{G^{4}}{4}+G^{3}+\frac{G^{2}}{2}\right)
$$

where

$$
G=\frac{F_{1}}{F_{2}}
$$

Because it was stated that the Chao1 richness estimator consistently overestimated species richness when samples were small, a modified version has been developed to overcome this problem. It is believed that overestimation was mainly found in data in which some species are very common and others very rare. Therefore, the estimator (ACE) was based on those species with 10 or fewer individuals in the sample (Chao et al. 1993):

ACE is based on the fact

$$
S_{\text {obs }}=S_{\text {rare }}+S_{\text {abund }}
$$

with $\mathrm{S}_{\text {rare }}$ being the number of of rare species, defined as those with 10 or fewer individuals when all samples are pooled and $\mathrm{S}_{\text {abund }}$ being the number of abundant species, defined as those with more than 10 individuals when all samples are pooled. 


$$
C_{\text {ace }}=1-F_{1} / N_{\text {rare }}
$$

is a sample coverage estimate based on the numbers of singletons $F_{1}$ and the number of rare species $\mathrm{N}_{\text {rare }}$ which is calculated as

$$
N_{\text {rare }}=\sum_{i=1}^{10} i F i
$$

So this sample coverage estimate is the proportion of all individuals in rare species that are not singletons. Then the ACE estimator of species richness is

$$
S_{\text {ace }}=S_{\text {abund }}+\frac{S_{\text {rare }}}{C_{\text {ace }}}+\frac{F_{1}}{C_{\text {ace }}} \gamma_{\text {ace }}^{2}
$$

$\gamma_{\text {ace }}^{2}$, which estimates the coefficient of variation of the $\mathrm{F}_{\mathrm{i}} \mathrm{s}$, is

$$
\gamma 2_{\text {ace }}=\max \left\{\frac{\text { S }_{\text {rare }}}{C_{\text {ace }}} \frac{\sum_{i=1}^{10} i(i-1) F_{i}}{\left(N_{\text {rar }}\right)\left(N_{\text {rare }}-1\right)}-1.0\right\}
$$

In addition to these extrapolations, rarefaction methods were used to randomise species accumulation from sample to sample (Colwell 1997, Shinozaki 1963) and for cumulative individuals (see Achtziger et al. 1992). There are documentations for both methods in Krebs (1989), who provides also software SHINO and RAREFACT (Krebs 1989). Sample order randomization with EstimateS (Colwell 1997) was set at 50 randomizations.

\section{Comparisons of species composition}

To compare the species composition between samples, the Soerensen index, the Dice index and the Morisita Horn species similarity indices were used. Soerensen $\left(\mathrm{C}_{\mathrm{S}}\right)$ is calculated as

$$
\mathrm{C}_{\mathrm{s}}=\frac{2 \mathrm{~S}_{1,2}}{\mathrm{~S}_{1}+\mathrm{S}_{2}}
$$

with $S_{1}$ or $S_{2}$ being the numbers of species in each community and $S_{1,2}$ being the number of species shared between them. $\mathrm{C}_{\mathrm{S}}$ is constrained between 0 (no species in common) and 1.0 (all species in common). If comparing a community with another, less completely assessed one, the Dice index $(\mathrm{M})$ can be applied:

$$
\mathrm{M}=\frac{2 \mathrm{~S}_{1,2}}{\mathrm{~S}_{\min }}
$$


with $S_{\min }$ being the number of species in the smaller sample.

As quantitative similarity measure, the Morisita Horn sample similarity index $\left(\mathrm{C}_{\mathrm{mH}}\right)$ was used. It has been found not being too much influenced by species richness or sample size and was calculated as:

$$
\mathrm{C}_{\mathrm{mH}}=\frac{2 \sum\left(\mathrm{anibn}_{\mathrm{i}}\right)}{(\mathrm{da}+\mathrm{db}) \mathrm{aN}^{*} \mathrm{bN}}
$$

where $\mathrm{aN}=$ total number of individuals in site $\mathrm{A}$ and $\mathrm{an}_{\mathrm{i}}=$ total number of individuals in the $i$ th species in A.

$$
\mathrm{da}=\frac{\sum \mathrm{an}_{\mathrm{i}}^{2}}{\mathrm{aN}^{2}}
$$

The Morisita Horn sample similarity index (Magurran 1988) and an estimator of shared species (Chao's shared species estimator, see Colwell 1997) were used to compare mist-net and standardised spot mapping samples from different compartments or vegetation types (see Tab. 1) of the study plot. Both parameters were calculated with the help of EstimateS 5 (Colwell 1997). Species similarity between different sampling periods or sites were grouped using a matrix of Morisita Horn sample similarity indices and average linkage clustering. Associations of mixed species foraging flocks were grouped using the Euclidian distance measure and weighted pair group average clustering. These and all other statistical analyses in this study were carried out with the help of STATISTICA 5.1 (Statsoft 1995). 


\section{Results}

\subsection{Vegetation structure of the Forêt Classée}

Surveys of the vegetation structure on the sixteen $2-\mathrm{km}$ transects confirmed that the Forêt Classée is dominated by young secondary growth (Fig. 11a). The natural forest in the Forêt Classée possessed considerable proportions of gaps (13\%) and younger secondary forest (S1, $33 \%$ and S2, 28\%). Only $24 \%$ of the sampling points were characterised by a multilayered canopy, indicating the high degree of disturbance. The mosaic character was very small-scaled, with patches changing mostly within distances of not much more than 50 metres. This pattern of repeated alternation in patches was similar for all transects, indicating that disturbance affected the Forêt Classée as a whole and not only in certain parts. On a somewhat larger scale, the structural pattern was superimposed by topographical differences. Gaps and younger succession stages were comparatively more frequent in depressions, at higher slopes and near watersheds, the vegetation consisted to a higher extent of mature patches (see below). Fig. 11b illustrates that the 110 ha plot reflects to a large extent the proportions of patches present in the whole Forêt Classée.
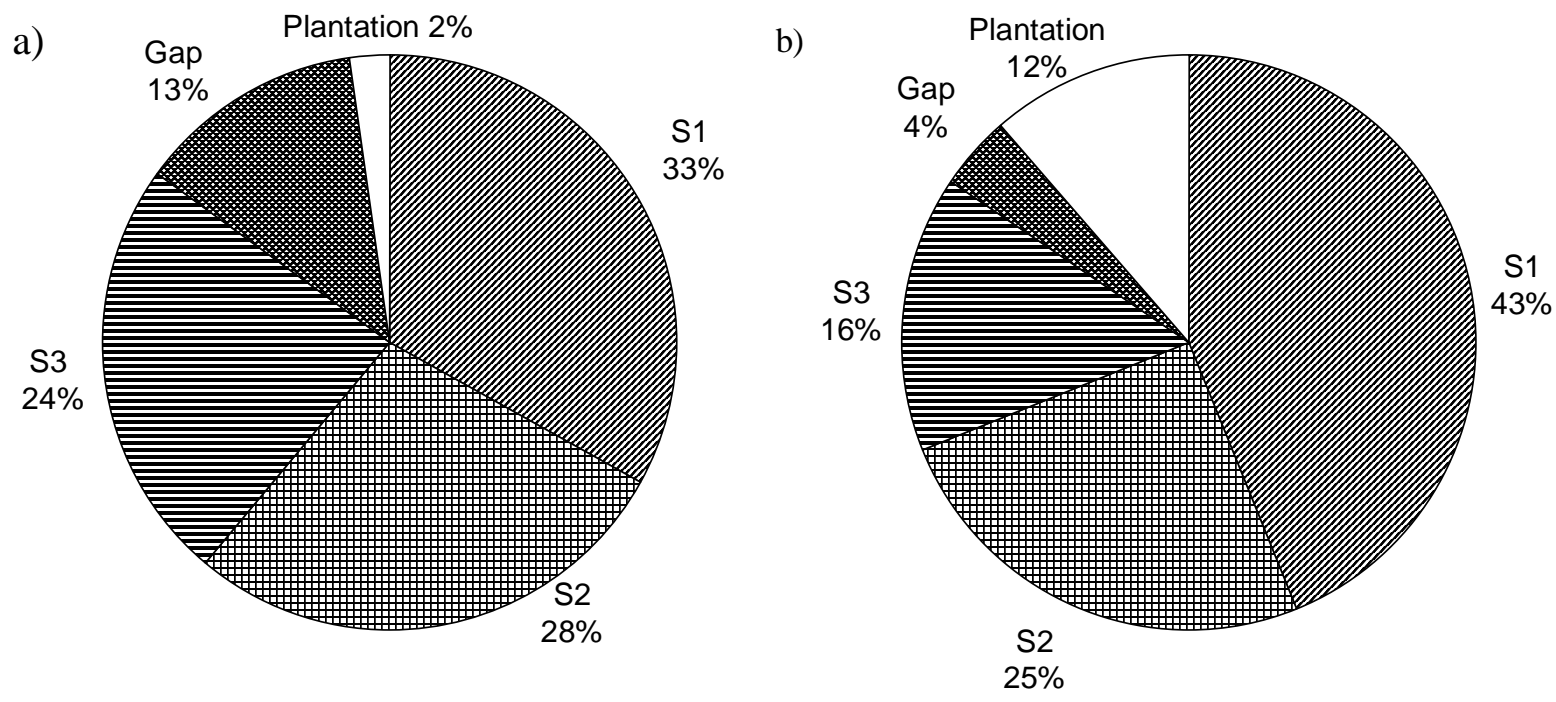

Fig. 11a, b: Composition of the habitat mosaic along (a) sixteen 2-km transects (Waltert 1996) and (b) in a 110 ha study plot, both in the Forêt Classée de la Bossematié, a degraded rainforest in south-east Côte d'Ivoire. Distribution of sample points $(n=621$ for $a, n=200$ for $b$ ) according to forest succession (gaps and three succession stages, for definition see Fig. 8). Plantations in (a) include recently abandoned agricultural encroachments.

\subsection{Vegetation structure of the study plot: management effects}

\section{Liberation thinning}

Quantitative measurements indicate a lower average size of overstorey trees (OTS) in the liberation thinning compared to the control area (Tab. 3). However, there was a large variation (coefficient of variation $>55 \%$ ) in the data and the differences were not significant on the 5\% level. Average dispersion of overstorey trees (OTD) remained unchanged between control and liberation thinning. In contrast, the obvious differences in understorey density between control 
and the liberation thinning were reflected by a significant difference in the density of understorey trees. The average dispersion of trees of $5-10 \mathrm{~cm}$ girth at breast height (UTD) was significantly higher in the control compared to the liberation thinning area.

\section{Plantation}

The Terminalia plantation showed a high average overstorey tree size (OTS), the median was even $4.4 \mathrm{~cm}$ higher than the median calculated for control, but differences were not significant (Mann-Whitney $U$ test, $\mathrm{p}=0.429$ ). The dispersion of plantation trees (OTD) was much higher than in the control compartment (Mann-Whitney $U$ test, $\mathrm{p}=0.000$ ). Also, the understorey tree dispersion (UTD) appeared to be far much higher in the plantation (Mann-Whitney $U$ test, $\mathrm{p}=$ 0.000) than in the control compartment.

\section{Swamp Forest}

In comparison to the control compartment, the swamp forest area showed a significantly lower average overstorey tree size (OTS, Mann-Whitney- $U$ test, $\mathrm{p}=0.008$ ). Overstorey trees were also more sparsely distributed, but the difference in overstorey tree dispersion was not significant (Mann-Whitney $U, \mathrm{p}=0.467$ ). The density of understorey trees did not differ either (Mann-Whitney U test, $\mathrm{p}=0.398$ ).

Tab. 3: Structural characteristics of the vegetation in the four main vegetation types of a 110 ha study plot in a degraded rainforest in south-east Côte d'Ivoire. Listed values are medians. OTS - Overstorey Tree Size, OTD - Overstorey Tree Dispersion, UTD - Understorey Tree Dispersion. Significance levels (p<values listed) are based on the Mann-Whitney $U$-test or Kruskal-Wallis ANOVA (Statsoft, 1995). Sampling was done at random sample points at $25 \mathrm{~m}$ intervals along $1,000 \mathrm{~m}$ transects. Sample sizes: Control $n=104$, Liberation thinning $n=58$, Plantation $n=22$, Swamp Forest $n=26$.

\begin{tabular}{lccccccc}
\hline & \multicolumn{5}{c}{ Vegetation type } & & \multicolumn{2}{c}{ Significance levels (p) } \\
\cline { 2 - 4 } & Control (C) & $\begin{array}{c}\text { Liberation } \\
\text { thinning (L) }\end{array}$ & $\begin{array}{c}\text { Swamp } \\
\text { Forest }(\mathrm{S})\end{array}$ & $\begin{array}{c}\text { Plantation } \\
(\mathrm{P})\end{array}$ & & $\begin{array}{c}\text { Kruskall-Wallis- } \\
\mathrm{p}(\mathrm{C}-\mathrm{L}-\mathrm{P}-\mathrm{S})\end{array}$ & $\begin{array}{c}\text { Mann-Whitney } \\
U \text { - } \mathrm{p}(\mathrm{C}-\mathrm{L})\end{array}$ \\
\hline OTS (cm) & 17.1 & 15.6 & 15.2 & 21.5 & & 0.000 & $>0.2$ \\
OTD (m) & 3.8 & 3.8 & 4.1 & 5.4 & & 0.001 & $>0.4$ \\
UTD (m) & 3.5 & 2.9 & 3.7 & 5.3 & & 0.000 & 0.001 \\
\hline OT/ha & 692.5 & 692.5 & 594.9 & 342.9 & & \\
UT/ha & 816.3 & 1189.0 & 730.5 & 356.0 & & & \\
\hline
\end{tabular}

\section{Succession stages}

The distribution of different succession stages (see

Fig. 8) between the vegetation types is shown in Tab. 4. The frequency of sampling points classified as „gaps“ was significantly higher than expected in both liberation thinning and swamp forest area compared to the control compartment (Tab. 4). The occurrence of succession stage (S1) was not disproportionally distributed among the vegetation types. However, older succession stages (S2 and S3) were more frequent in control than liberation thinning or swamp forest. The data suggest that the distribution of succession stages did not differ much between liberation thinning and swamp forest, both showing a high percentage of young regrowth. 
Tab. 4: Distribution of the morphologically classified succession stages (see Fig. 8) between the vegetation types control, liberation thinning and swamp forest. Expected distributions were calculated from the general distribution of sampling points in the respective vegetation types.

\begin{tabular}{|c|c|c|c|c|c|c|c|c|}
\hline & \multicolumn{2}{|c|}{ Gap } & \multicolumn{2}{|c|}{ S1 } & \multicolumn{2}{|c|}{ S2 } & \multicolumn{2}{|c|}{ S3 } \\
\hline & Obs. & Exp. & Obs. & Exp. & Obs. & Exp. & Obs. & Exp \\
\hline Control & 9 & 17.0 & 36 & 44.5 & 39 & 28.6 & 21 & 14.8 \\
\hline Liberation thinning & 14 & 9.6 & 30 & 25.0 & 10 & 16.1 & 5 & 8.3 \\
\hline Swamp forest & 8 & 4.4. & 15 & 11.5 & 3. & 7.4 & 1 & 3.8 \\
\hline $\begin{array}{l}\chi^{2} \\
P\end{array}$ & & & & & & & & \\
\hline
\end{tabular}

Comparing the measured vegetation parameters for the different succession stages (

Fig. 8), it was found that overstorey tree size (OTS) increased with increasing succession, but the correlation was only very weak (Gamma rank correlation for multiple ties, $\gamma=0.100, p<$ 0.05). Average overstorey tree dispersion (OTD) declined with habitat maturity, but the correlation was not significant. The average understorey tree dispersion (UTD) was largest at gap sites, but again there was no significant correlation with habitat maturity. 


\subsection{Avifauna of the region}

In the following, results from bird observations during the total period of fieldwork in the Bossematié area (appr. 640 sq. km, see Fig. 2) are given. In contrast to the results of chapter 6.4, this chapter summarises all bird observations from the Forêt Classée and the surrounding area. All species records included are own observations, reports of other observers were only considered for classifying relative abundance (as given in appendix A).

\subsubsection{General composition}

\section{Species richness and habitat}

A total of 236 bird species have been recorded in the Bossematié area (see appendix A). Most of the species that were expected from the geographical situation of the study area were present. A first comparison of the species composition showed that many of the birds listed have been classified as „primary forest species“ (sensu Thiollay 1985a). A more detailed analysis of available literature indicated that $83 \%$ of the species found are true forest zone species (see annotated check-lists of Ghana and Liberia, Grimes 1987 and Gatter 1998). Only a small fraction (17\%) are either ubiquitous species (or habitat specialists such as waterbirds) or belong to the savannah bird community. Most of the latter species have only been observed during the dry season and most likely represent non-breeders (for evidence of breeding see appendixes $\mathrm{A}$ and $\mathrm{C}$ ).

\section{Restricted range species}

$113(61 \%)$ of the 184 species that belong to the biome-restricted assemblage of the GuineaCongo Forests in Côte d'Ivoire (Fishpool in prep.) were found in the area. Four species are Upper Guinean restricted species: Brown-cheeked Hornbill Ceratogymna cylindricus, Greentailed Bristlebill Bleda eximia, Rufous-winged Illadopsis Illadopsis rufescens and Sharpe's Apalis Apalis sharpei. Two more Upper Guinean endemics, Western-Wattled Cuckoo-Shrike Campephaga lobata and Copper-tailed Glossy Starling Lamprotornis cupreocauda have been reported (Ellenberg \& Yaokokoré-Beibro, pers. comm.) but their presence could not yet be confirmed. According to locals, one Upper Guinean endemic, White-breasted Guineafowl Agelastes meleagrides, was present before logging, but has not been recorded since.

\section{Species of conservation concern}

Five species of conservation concern were stated (Collar et al. 1994, Stattersfield et al. 1998 and Tab. 5). These are the Vulnerable Green-tailed Bristlebill Bleda eximia, the NearThreatened species Brown-cheeked Hornbill Ceratogymna cylindricus, Yellow-casqued Wattled Hornbill Ceratogymna elata, Rufous-winged Illadopsis Illadopsis rufescens (near Threatened), and the restricted range species Sharpe's Apalis Apalis sharpei.

\subsubsection{Comparison of the Bossematié area with the Taï region}

An avifaunal survey of comparable effort and range of habitat types has been carried out in and around the Taï National Park (wet evergreen forest in West-Côte d'Ivoire). The study revealed the presence of about the same number of species, namely 230 (Gartshore et al. 1995 and Tab. 5). However, whereas only $48 \%$ of the 236 species found in the Bossematié area are Guinea- 
Congo forest species, the respective percentage on the Taï list amounts to $c$. $68 \%$. In addition, whereas only four of the Bossematié species are considered as threatened (Collar et al. 1994), fourteen were found in Taï, including a high number of species only known from the Liberian sub-centre of endemism.

Tab. 5: Species richness, habitat and conservation status of birds observed in two rainforest areas in Côte d'Ivoire (from Gartshore et al. 1995, Waltert et al. 1999)

\begin{tabular}{lcc}
\hline & $\begin{array}{c}\text { Bossematié area } \\
(c .640 \mathrm{sq} . \mathrm{km})\end{array}$ & $\begin{array}{c}\text { Taï National Park } \\
(c .4000 \mathrm{sq} . \mathrm{km})\end{array}$ \\
\hline Number of species & 236 & 230 \\
Guinea-Congo forest biome species & $113(48 \%)$ & $157(68 \%)$ \\
Upper Guinean forest species & 4 & 12 \\
Number of threatened species (Collar et al. 1994, & 5 & 14 \\
Stattersfield et al. 1998) & & \\
\hline
\end{tabular}

However, using Taï National Park as a reference for the Bossematié area is problematic, because the Bossematie Forest is a semi-deciduous forest and situated to the East of the Baoule $\mathrm{V}$, while the Taï region is situated mainly within the wet evergreen forest zone of the Liberian sub-centre of endemism. Although only appr. 9\% of the West African forest bird species seem to be confined to particular types of humid forest (Keast 1990), the Taï National Park with its many streams harbours a considerable proportion of species associated with permanent water, which are completely lacking inside the Bossematié Forest.

\subsubsection{Comparison of the Bossematié Forest with Bia National Park}

There is no large unfragmented and unlogged reference area in the same vegetation belt and biogeographic area as the Bossematié Forest. However, the Bia area in Ghana is less than 30 $\mathrm{km}$ distant from the Bossematié Forest (Fig. 1). At present, only a fraction of this forest block is still unlogged, parts of it being deforested or re-classified as game production reserve, where much logging took place (Hawthorne 1993). Fortunately, a bird species list has been made there (Taylor \& MacDonald 1978) in past times, when the site was still a large, unlogged area containing more than 306 sq. km of primary forest. Farmland was not included in this past relevé.

Comparing the species list of the Bossematié Forest (only the Forêt Classée) with the Bia list of Taylor \& MacDonald (1978), we find a much higher similarity in species richness and composition than in the above comparison between Bossematie and Taï. The number of species recorded in the Bossematié Forest and the Bia National Park is very similar, 159 in the Bossematié Forest and 160 in Bia. A very high number of 146 species is shared between the areas resulting in a Soerensen index of $92 \%$. However, on the Bia list, seven Upper Guinean endemics appear, whereas only four of these, Ceratogymna cylindricus, Bleda eximia, Illadopsis rufescens and Apalis sharpei were recorded in the Bossematie Forest. It is possible that among the three unrecorded endemics, at least two, Campephaga lobata and Lamprotornis cupreocauda, are present in very low numbers. However, for one restricted range species on the Bia list, the Yellow-throated Olive Greenbul Criniger olivaceus, no records are present for the Bossematié area. 


\subsection{4 $\alpha$-Diversity of understorey birds in the Bossematié and other forests}

Comparisons of complete bird species lists derived from a combination of methods are often of little value when data from different observers are used. Mist-netting, if well-documented, facilitates comparisons, because it is less biased by observer skills and sample effort can be standardised much easier. There are not many available mist-net studies on diversity patterns of West African forest understorey birds. However, in the following, results are compared with Allport et al. 1989 (primary forest in Gola, location in Fig. 1) and with own results from primary forest (Nimba forest reserve, Fig. 1, Yaokokore-Beibro \& Waltert unpublished) and partly logged forests in the Upper Guinean region (Mabi, Fig. 1). The values from the reserves are derived from standardised samples from $c .2$ ha of forest covered by $c .200 \mathrm{~m}$ mist-nets in two (consecutive) days.

The most striking difference between the sites is the number of individuals being captured. The highest number of individuals was obtained in the heavily logged Bossematie Forest and the partly logged Mabi Forest. In contrast, in both primary forest areas, Gola unlogged and Nimba, the number of individuals captured with a comparable effort was much lower. For the Gola forest this is partly due to a slightly different methodology, since nets were closed between 10:00 and 15:00 hrs (Allport et al. 1989). But this cannot fully account for the difference since this time span is outside the main activity periods of birds. Moreover, in the Nimba sample, exactly the same methodology has been applied as in the Bossematié. As numbers of captured individuals differed between sites, diversity can best be compared by the $\alpha(\log$-series $)$ index or the (more dominance-related) Simpson index. Comparisons of these indices between areas show that spot-diversity is highest in the two primary forests (Nimba and Gola unlogged) compared to all other sites (Tab. 6). In addition, in the Nimba forest reserve, the highest Shannon index and Shannon-evenness of all samples were obtained. Diversity in the Bossematié control compartment and the partly logged Mabi Forest was lower than in the selected sample from the disturbed compartment of the Bossematié Forest.

Tab. 6: $\alpha$-diversity from understorey bird samples in forest reserves of Côte d'Ivoire and Sierra Leone (*Yaokokoré-Beibro \& Waltert, unpublished data; ** data from Allport et al. 1989). Diversity is calculated for two $100 \mathrm{~m}$ mist-net lines set within a 2 ha area. Nimba and Gola unlogged are undisturbed primary forest areas, Mabi is logged in parts. Abbr.: Dist. - disturbed compartment; Sim. - Simpson index; alpha - Fisher's alpha index; $H_{S}$ - Shannon index.

\begin{tabular}{lccccccc}
\hline Locations & $\begin{array}{c}\text { Individuals } \\
(\mathrm{I})\end{array}$ & $\begin{array}{c}\text { Species } \\
(\mathrm{S})\end{array}$ & $\begin{array}{c}\text { Singletons } \\
(\% \text { of } \mathrm{S})\end{array}$ & $\begin{array}{c}\text { Div. } \\
\left(\mathrm{H}_{\mathrm{S}}\right)\end{array}$ & $\begin{array}{c}\text { Evenness } \\
\left(\mathrm{H}_{\mathrm{S}} / \mathrm{ln} \mathrm{S}\right)\end{array}$ & $\begin{array}{c}\text { Div. } \\
(\text { Sim. })\end{array}$ & $\begin{array}{c}\text { Div. } \\
(\text { alpha })\end{array}$ \\
\hline $\begin{array}{l}\text { Bossematié } \\
\text { Control }\end{array}$ & 150 & 25 & 28 & 2.60 & 0.81 & 9.9 & $8.57( \pm 1.2)$ \\
$\quad$ Dist. & 165 & 26 & 23 & 2.80 & 0.86 & 13.1 & $8.68( \pm 1.1)$ \\
Mabi & 101 & 19 & 16 & 2.56 & 0.87 & 10.4 & $6.91( \pm 1.1)$ \\
*Nimba & 75 & 23 & 30 & 2.86 & 0.91 & 17.0 & $11.32( \pm 2.07)$ \\
***ala Forest & & & & & & & \\
$\quad$ unlogged & 43 & 17 & 41 & 2.59 & 0.92 & 17.1 & $10.4( \pm 2.6)$ \\
$\quad$ logged & 65 & 20 & 40 & 2.75 & 0.91 & 13.9 & $9.9( \pm 1.9)$ \\
\hline
\end{tabular}




\subsubsection{The Bossematié forest compared to the surrounding area}

Inside the Forêt Classée, 159 bird species were encountered, whereas 122 were found in the surrounding area. Most of the Guinea-Congolian spp. and all (Upper Guinean) restricted range spp. were only observed inside the forest. Of the 159 species identified inside the Forêt Classée, 110 were exclusively observed within the forest borders, corresponding to a species loss of 70 percent. Although most time was spent inside the Bossematié Forest and several forest species present in farmland may be unrecorded, the observed rate of species loss seems ecologically significant. Interestingly, a study in Liberia (Kofron \& Chapman 1995) also reports a species loss of $70 \%$ from virgin forest to surrounding farmland.

The 122 species recorded in the surrounding farmland represent an avifauna completely different from the forest. The most common birds include ubiquitous species such as Common Bulbul Pycnonotus barbatus or the Pied Crow Corvus albus and forest edge species such as the Whistling Cisticola Cisticola lateralis and several estrildine finches. No Ceratogymna hornbills and only a few bulbuls Pycnonotidae were recorded in the farmland. Densities of most of the Guinea-Congo-biome restricted species were considerably lower in the farmland than in the Forêt Classée. No Upper Guinean endemic has been encountered in the surrounding farmland during the study. Only a few forest understorey species were common in dense farmbush, for example Little Greenbul Andropadus virens and the Ahanta Francolin Francolinus ahantensis. Some forest species such as Grey-headed Bristlebill Bleda canicapilla or the Yellow-whiskered Greenbul Andropadus latirostris can be found in small remnant forest patches. 


\subsection{Avifauna of the study plot}

\subsubsection{Species richness and diversity}

During the spot-mapping censuses on the 110 ha study plot, 2508 encounters of solitary individuals or groups were noted. A total of 118 species (709 social units/territorial individuals, or defined as "pairs" in the following) were found to have at least parts of one home range in the area. Eighteen additional species recorded during mist-netting or supplementary to spot-mapping amounts the total number of species recorded to 136. All of them can be regarded as members of the breeding bird community, although breeding records were only obtained for 42 species (Appendices A and C). The taxonomical composition of the community is shown in Fig. 12.

Based on the data collected during standardised spot-mapping in June-August 1997, the diversity of the breeding bird community was calculated at different scales. The number of species recorded in each of the two 18.3 ha sectors in the control compartment was remarkably similar (71, 72 resp.). The number of species recorded within the 36.7 ha (both 18.3 ha sectors) in control increases to 86 . On the whole study plot, including the various vegetation types, 118 species were stated. The data suggest that the species inventory on the 110 ha scale was close to complete. Out of the 118 species assessed by spot-mapping, 29\% were singletons (one territory at least partly inside the plot). A doubling of the sample size (study plot of 220 ha) would only increase the number of species by a factor 1.3 , leading to a total of 152 species (Tab. 7). The local species pool on the plot calculated with the estimators of true species richness were within the range 136 to 139 (Chao1, ACE, Colwell 1997).

Tab. 7: Number of pairs (social units/groups), number of species (S), diversity (Shannon $\mathbf{H}_{\mathrm{S}}$, Fisher's alpha, Simpson after Magurran 1988) and abundance-based estimator of total species richness (ACE, see Colwell 1997) from mapping data in successively larger (nested) areas of the heavily degraded Bossematié Forest. 18.3 ha and 36.7 ha areas are fractions of a less disturbed "control" compartment, 110 ha represents a study plot containing various vegetation types, including a 5-years old monodominant tree plantation and a liberation thinning area.

\begin{tabular}{lccc}
\hline & 18.3 ha & 36.7 ha & 110 ha \\
\hline Pairs & 170 & 320 & 709 \\
Species (S) & 72 & 86 & 118 \\
Singletons (\% of S) & 43.1 & 29.1 & 29 \\
Diversity (Hs) & 4.05 & 4.14 & 4.26 \\
Evenness (Hs/lnS) & 0.95 & 0.93 & 0.89 \\
Diversity (alpha) & $47.14( \pm 5.89)$ & $38.6( \pm 3.4)$ & $40.4( \pm 2.52)$ \\
Simpson (1/D) & 65.0 & 57.4 & 52.6 \\
ACE & 101.5 & 105.2 & 139.4 \\
\hline
\end{tabular}


a) Species

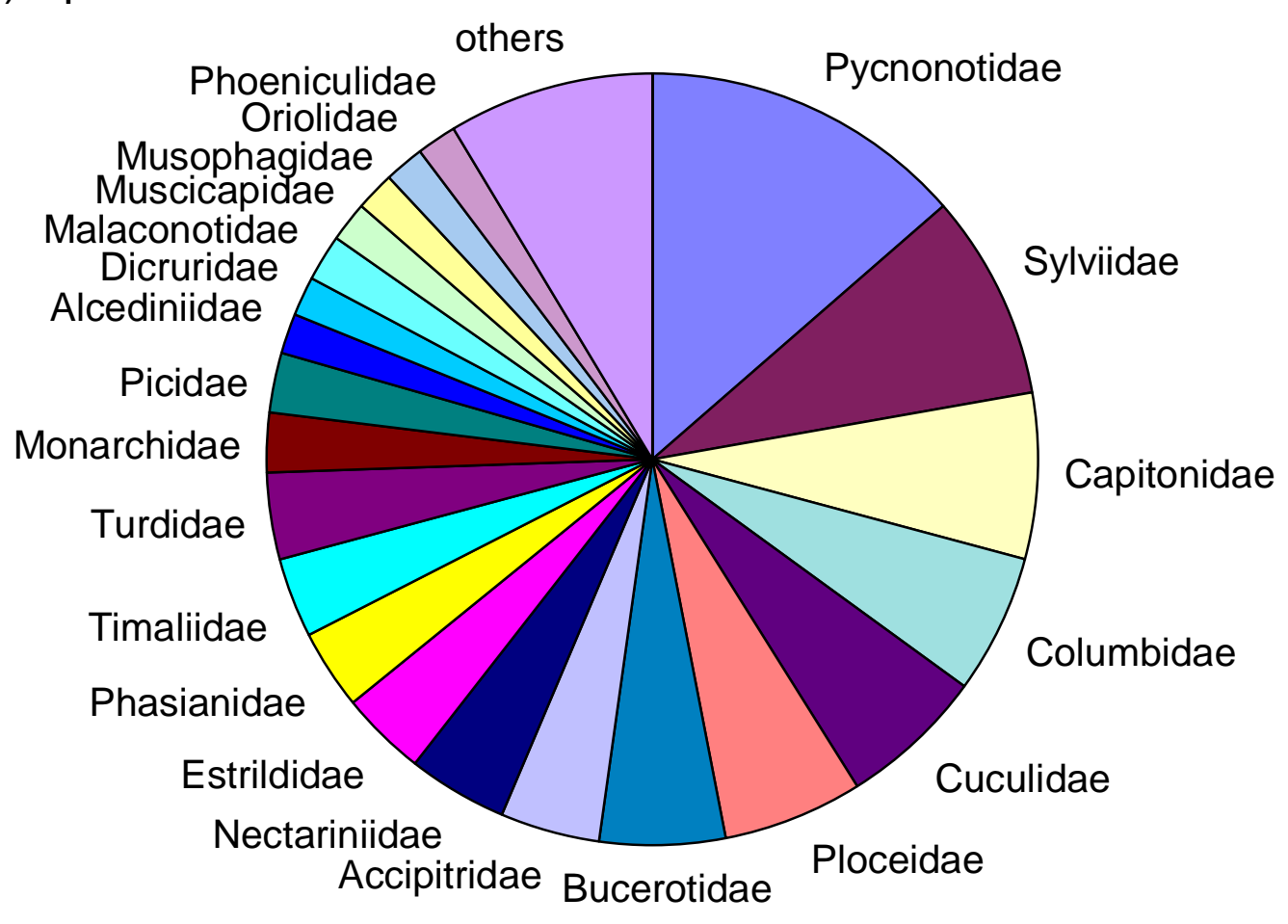

b) Pairs

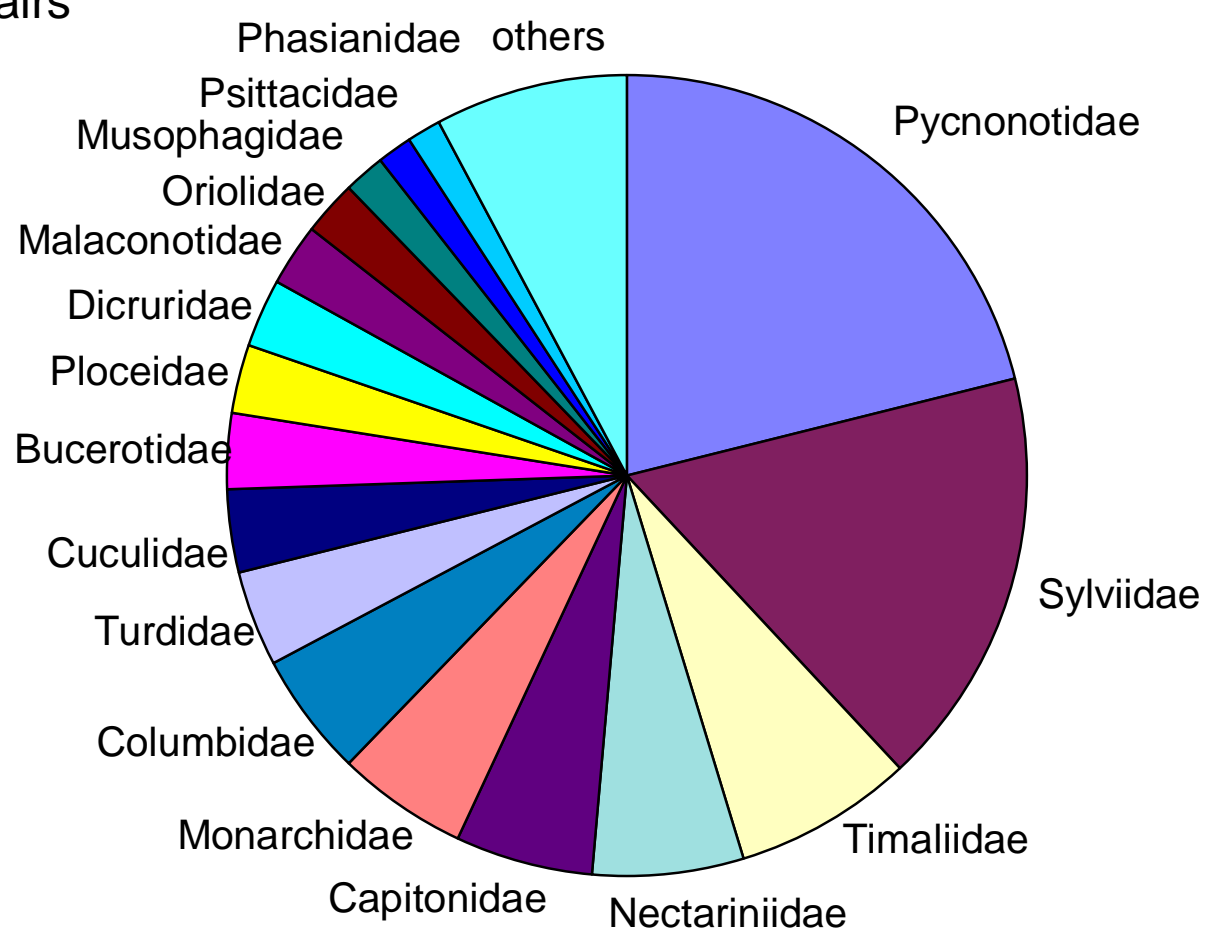

Fig. 12: Taxonomical composition for a) species and b) individuals of the avifauna recorded on a 110 ha study plot in a heavily degraded rainforest in south-east Côte d'Ivoire. 


\subsubsection{Density patterns}

The overall estimated density was 645 pairs $(100 \mathrm{ha})^{-1}$. There was a considerably high proportion of species with an abundance lower than 0.25 pairs $(100 \mathrm{ha})^{-1}$. This high proportion can only partly be attributed to under-recording of species difficult to census (Fig. 13).

The species can be classified in five groups:

1. The four numerically dominant species are Yellow-whiskered Greenbul Andropadus latirostris, Brown Illadopsis Illadopsis fulvescens, Green Hylia Hylia prasina and the Olive Sunbird Nectarinia olivacea. All these species occupy the understorey or lower midstrata in African rainforests, but the estimated density between 26 and 36 pairs (100 ha $)^{-1}$ are much lower in undisturbed forests elsewhere in Upper Guinea.

2. Nine subdominant species (between 10 and 20 pairs $\left.(100 \mathrm{ha})^{-1}\right)$, all medium to large-sized understorey/lower midstorey insectivores, generally showing lower densities in undisturbed primary forests.

3. 67 species with a density between one and ten pairs (100 ha $)^{-1}$.

4. Nine truly resident and well-known species with densities between 0.25 and 1 pairs (100 ha) $)^{-1}$.

5. 47 species with a density below 0.25 pairs (100 ha $)^{-1}$. Only one of these, the WesternBanded Snake Eagle Circaetus cinerascens, can be considered vagrant in the area, because it is known to breed in savannah country. The proportion of species present in this group due to under-recording is not high either. Only seven species are either generally shy (e.g. the Long-tailed Hawk Urotriorchis macrourus), nocturnal (e.g. the African Wood Owl Strix woodfordii) or have voices not yet documented (e.g. Little Green Sunbird Nectarinia seimundi or Preuss's Weaver Ploceus preussi). The majority (39 spp.) can be considered as truly rare (Fig. 13).

The abundance distribution in Fig. 13 did not differ significantly from a log-normal distribution ( $\chi^{2}$ Goodness of fit test, $\chi^{2}{ }_{8 \mathrm{df}}=11.129, \mathrm{p}=0.195$ ). Due to the elevated number of species with a very low abundance, the pattern was only slightly different from a log-series distribution $\left(\chi^{2}\right.$ Goodness of fit test, $\left.\chi^{2}{ }_{5 \mathrm{df}}=9.695, \mathrm{p}=0.084\right)$. The log-normal fit is very good when only including species with an abundance $>0.25$ pairs $(100 \mathrm{ha})^{-1}\left(\chi^{2}\right.$ Goodness of fit test, $\left.\chi^{2} 7 \mathrm{df}=2.754, \mathrm{p}=0.907\right)$. In this case, a clear difference from the log-series distribution was found ( $\chi^{2}$ Goodness of fit test, $\chi^{2}{ }^{5 d f}=12.326, p=0.031$, Fig. 13).

Evenness (Tab. 7) was less pronounced than in Amazonian primary rainforest where abundance distributions follow a broken-stick abundance model with about equal numbers of species in all abundance classes between $<0.5$ and up to 8 pairs/100 ha (Thiollay 1994b, see also Terborgh et al. 1990). 


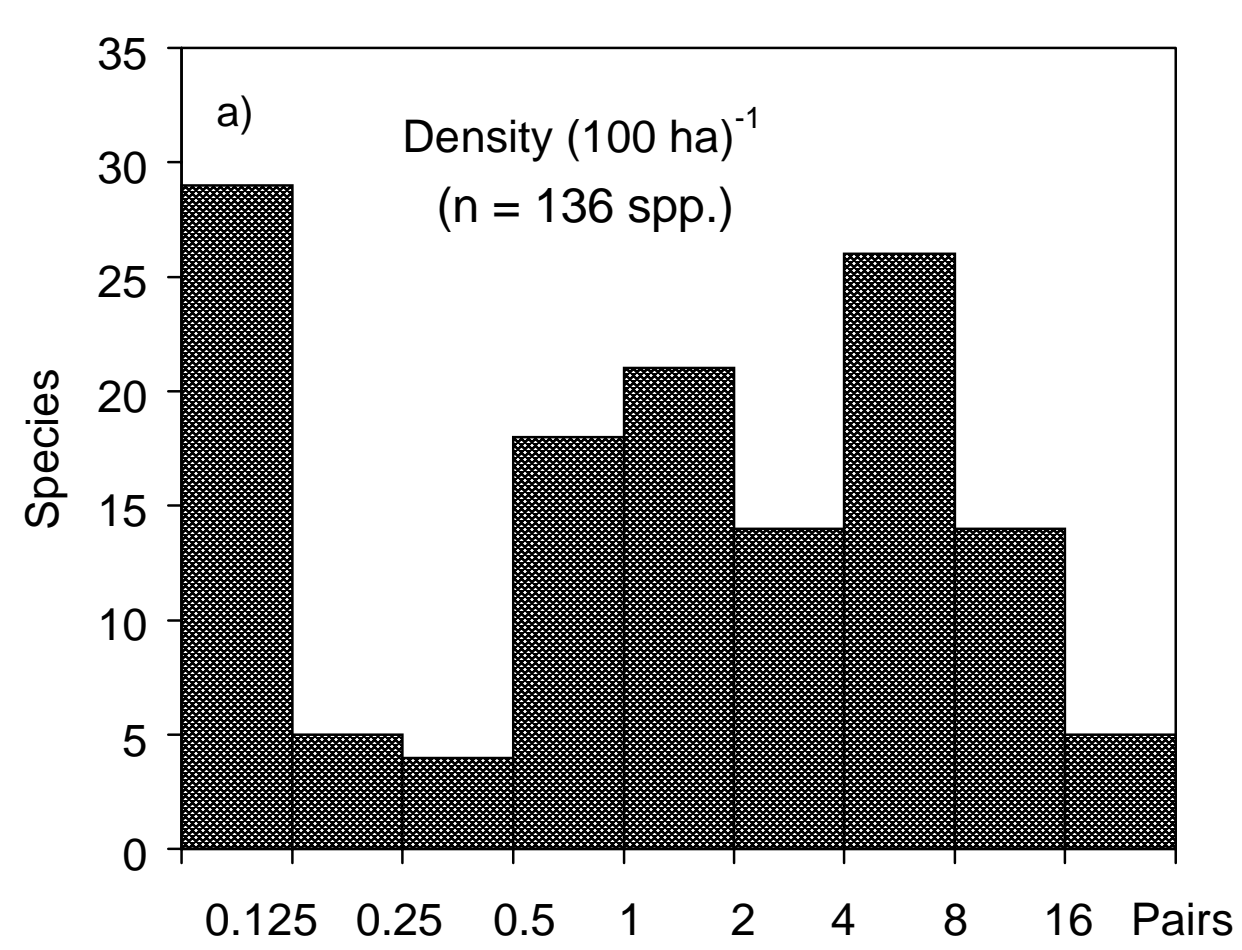

Fig. 13: Distribution of (a) density and (b) weight among the bird species recorded on a 110 ha plot ( $\log _{2}$ scale) in a heavily logged rainforest in south-east Côte d'Ivoire.

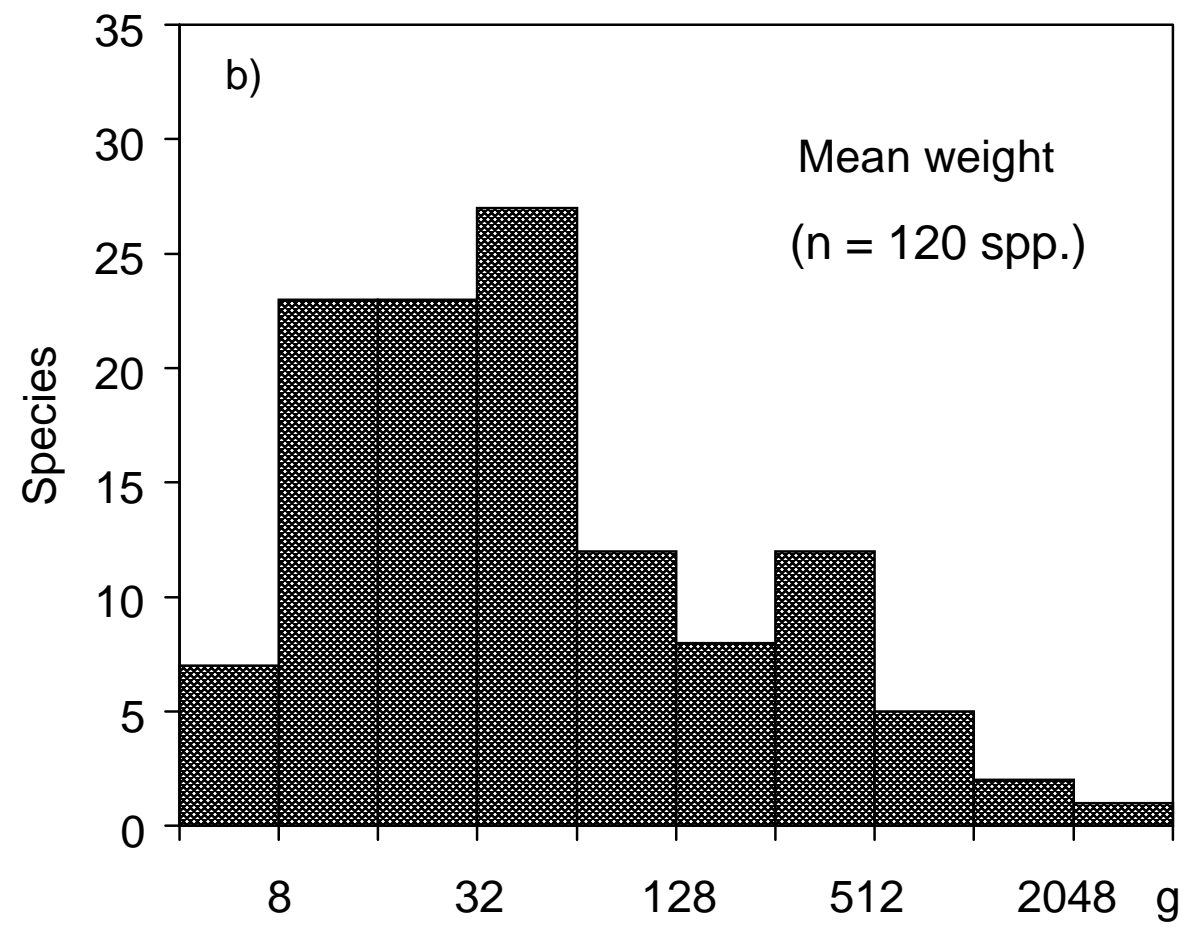

\subsubsection{Density and weight}

For 120 bird species, weight data was adopted from Karr (1976), Brown et al. (1982), Fry et al. (1988), Keith et al. (1992), Urban et al. (1986, 1997) and own measurements. The distribution of body weights among species is as follows: $6 \%$ are very small $(<8 \mathrm{~g}), 61 \%$ are small to medium-sized ( $8-64 \mathrm{~g}), 31 \%$ are large $(65-510 \mathrm{~g})$ and $3 \%$ belong to the highest weight class $(0.5-5 \mathrm{~kg})$. Naturally, the distribution is different between particular guilds. 
Nectarivores all are small, and carnivores all are large species. Granivores, frugivores and omnivores all weigh more than $13 \mathrm{~g}, 41 \%$ weigh less than $64 \mathrm{~g}$ and $18 \%$ more than $500 \mathrm{~g}$. Insectivores have no species over $500 \mathrm{~g}, 69 \%$ in the $8-64 \mathrm{~g}$ size class and $3 \%$ under $8 \mathrm{~g}$.

There was a modest, but highly significant negative correlation between weight and density (Spearman Rank $\mathrm{R}=-0.520, \mathrm{n}=96$ spp., $\mathrm{p}=0.000$, see Fig. 14). This inverse relation holds true for the insectivores (Spearman $\mathrm{R}=-0.326, \mathrm{n}=56$ spp., $\mathrm{p}=0.014)$, granivores $(\mathrm{R}=-$ $0.502, \mathrm{n}=11, \mathrm{p}=0.115)$ and omnivores $(\mathrm{R}=-0.464, \mathrm{n}=6, \mathrm{p}=0.354)$. The relationship was weak and insignificant in frugivores $(\mathrm{R}=-0.186, \mathrm{n}=17$ spp., $\mathrm{p}=0.474)$, showing a wider spectrum of sizes (13 - $921 \mathrm{~g})$ than e.g. the insectivores $(7-297 \mathrm{~g})$.

The relationship between size and abundance of animals has been typically found to be

$$
\mathrm{A}=\mathrm{W}^{-0.75}
$$

with $A=\log$ (ecological density [ind./sq. km]), and $\mathrm{W}=\log$ (body weight $[\mathrm{g}]$ ), (see Damuth 1991).

When transforming group densities to individual densities by multiplying it in a very conservative way by 2 , the power of this function is near the theoretical one, namely -0.76 . However, because most species live in groups of more than two individuals, average group size for all bird species present in the Bossematié area should be higher than 2. Assuming an average group size of 2.5 , the slope of the curve is -0.5 , which is already well above the theoretical one.

\subsubsection{Density and vertical stratification}

For 131 out of the 139 species recorded on the study plot, data on preffered foraging strata is well-documented in literature. For each species, the mode of vertical distribution patterns documented in Gatter (1998) was assigned to one out of four classes: ground and understorey (0-5m), lower midstorey (6-10m), upper midstorey (11-20 m), and canopy (>20m). Each class was well-represented: canopy species comprised the largest group with 46 species, followed by 39 ground and understorey species and 34 upper midstorey species. Lower midstorey species were represented only by twelve species.

There was a moderate, but highly significant correlation between the abundance and vertical foraging height in the $107 \mathrm{spp}$. for which adequate abundance estimates were obtained. The Gamma rank correlation coefficient $\gamma$ indicates a decreasing abundance with increasing foraging height $(\gamma=-0.371, \mathrm{n}=107$ spp., $\mathrm{p}=0.000$, see Fig. 15). As described above, the four numerically dominant and most of the subdominant species are understorey species, mainly foraging below $5 \mathrm{~m}$ height (Gatter 1998). However, after excluding these four species, the correlation is still significant $(\gamma=-0.321, \mathrm{n}=103$ spp., $\mathrm{p}=0.000)$. The most abundant midstorey foraging species, Olive Longbill Macrosphenus concolor, a small sylviid preferably exploiting liana-tangles around tree-stems, and the Red-bellied Paradise Flycatcher Terpsiphone rufiventer only reach half of the densities of the most dominant understorey species. Among the most dominant canopy species, the Drongo Dicrurus adsimilis, a very 
prominent arboreal insectivorous species, only reaches one third of the densities of the dominant understorey species. As density is correlated with weight (see above), the negative correlation between foraging height and density could also be caused by the fact that higher foraging species are larger than understorey species. However, this cannot fully explain the pattern, since there only was a very weak insignificant correlation between the preferred foraging height and the body weight (Gamma rank correlation coefficient $\gamma=0.141, \mathrm{n}=107$ spp., $\mathrm{p}=0.084)$.

\subsubsection{Density and geographic range}

The community on the 110 ha plot was mainly composed of either Guinea-Congolian restricted (88 spp., Fishpool in prep.) or typical African rainforest species (25 spp.). Only four species were Upper Guinean endemics (EBA 085, Stattersfield et al. 1998) and 18 species belong to the group of species found in various habitats all over Africa (ubiquitous, see appendix C). There was no significant correlation between abundance and geographic range (Gamma rank correlation coefficient $\gamma=-0.0412, \mathrm{n}=106 \mathrm{spp} ., \mathrm{p}=0.668$ ) and no significant difference between species from different geographic range classes (Kruskal-Wallis ANOVA, H [3, n = 105 spp.] $=3.912, p=0.271)$. However, the most abundant species on the plot either belonged to the Guinea-Congolian rainforest biome species assemblage (Fishpool, in prep.) or to the African rainforest species. Both Upper Guinean restricted species (EBA 085, Stattersfield et al. 1998) and ubiquitous species did not reach considerable densities on the plot (see Fig. 16).

\subsubsection{Density and diet}

Fig. 17 shows the abundance distribution between different feeding guilds. The overall interspecific comparison indicates a significant differrence in average density between feeding guilds (Kruskal-Wallis Anova, $\mathrm{H}[5, \mathrm{n}=107]=17.6139, \mathrm{p}=0.004$ ). The most abundant species was the medium-sized omnivorous Greenbul Andropadus latirostris. Its congener, A. virens, also omnivorous, was very abundant as well. Their densities were only matched by small nectarivores, the insectivorous timaliid Illadopsis fulvescens and the sylviid Hylia prasina. However, applying pairwise tests, average densities did not differ between omnivorous and insectivorous species (Mann-Whitney $U$ test, $U=135.5, p=0.187$ ), but the medium-sized omnivores were more abundant than either frugivores (Mann-Whitney U test, $U$ $=23.0, \mathrm{p}=0.049$ ), granivores (Mann-Whitney $\mathrm{U}$ test, $\mathrm{U}=15.5, \mathrm{p}=0.076$ ) or carnivores (Mann-Whitney $\mathrm{U}$ test, $\mathrm{U}=3.0, \mathrm{p}=0.005$ ). On average, omnivores were about equally abundant as the small nectarivorous species (Mann.-Whitney $U$ test, $U=10.5, p=0.748$ ). The abundance of insectivores and granivores did not differ significantly (Mann-Whitney U-test, U $=392.5, \mathrm{p}=0.100$ ), but were higher in insectivores than in either frugivores (Mann-Whitney $\mathrm{U}$ test, 392.5, $\mathrm{p}=0.048$ ) or carnivores (Mann-Whitney $\mathrm{U}$ test, $\mathrm{U}=3.0, \mathrm{p}=0.022$ ). On average, nectarivorous species showed a higher abundance than either insectivores (Mann-Whitney $U$ test, $\mathrm{U}=55.5, \mathrm{p}=0.050$ ), granivores (Mann-Whitney $\mathrm{U}$ test, $\mathrm{U}=2.5, \mathrm{p}=0.010$ ), frugivores (Mann-Whitney $U$ test, $U=1.5, p=0.003$ ), and carnivores (Mann-Whitney $U$ test, $U=0.0, p=$ 0.064). 


\subsubsection{Densities of endemics and other species}

As explained above, the densities of the four numerically dominant species on the 110 ha plot were much higher than densities usually found in undisturbed primary forest. However, as no comprehensive community study for Upper Guinean rainforest exists, only relative abundance data from the Bia National Park (Holbech 1992) and the Taï National Park (Gartshore et al. 1995) and quantitative and semi-quantitative data from Uganda (Owiunji \& Plumptre 1998, Dranzoa 1998), Gabon (Brosset \& Erard 1986) and Cameroon (Fotso 1994) can be consulted. The latter three countries, however, are not situated in the Upper Guinean rainforest zone.

Because of this lack of detailed Upper Guinean forest bird community studies, it is hard to decide for which species the densities found in the Bossematié in- or decreased compared to primary forest. However, from comparisons with Holbech's (1992) logging studies in the Bia National Park, at least 64 out of the 136 species might show a density change compared to primary forest. The proportion of species with a higher densities (24\%) than in the unlogged forest in Bia was comparable to the proportion of species with lower densities (24\%). For 72 species (or $53 \%$ of 136 spp.) the comparison primary forest and Bossematié Forest did not reveal differences in densities, but actual differences could have been masked by variability among observers or by census methods.

One bird family whose densities seemed to be most negatively affected by the present conditions in the forest are the Bucerotidae, with five species (84\% out of six) occurring in densities lower than in primary forest. One additional species, the Black-casqued Wattled Hornbill Ceratogymna atrata, is present in the Bossematié Forest, but was not recorded on the 110 ha plot due to its rarity. In contrast, most Sylviidae (75\%) were found to be more common than in primary forest. Among the Pycnonotidae, an equal number $(50 \%)$ of the species were rarer, whereas the rest was more common than in primary forest. Geographic range was the most striking feature being linked to local densities. All four Upper Guinean restricted species and c. $64 \%$ of the Guinea-Congolian species showed lower densities than in primary forest, whereas this proportion was only c. $36 \%$ in African rainforest species and $0 \%$ in ubiquitous species. The apparent rarity of the Upper Guinean forest species in the Bossematié Forest is illustrated in Tab. 8., where densities are compared with those available from literature.

Tab. 8: Densities of the four Upper Guinean endemics so far recorded in the Bossematié area, as calculated for the Bossematié Forest and mature rainforests. Weight and feeding guild are also given. For Ceratogymna, individual densities are given, others are pair densities. * data from Ceratogymna albotibialis (Cameroon, Whitney \& Smith 1998); ** data from Bleda notata (Gabon, Brosset \& Erard 1986); *** data from Gola, Sierra Leone (Allport et al. 1989). Guild: can. - canopy, und. - understorey, frug - frugivorous, ins. - insectivorous.

\begin{tabular}{lcccc}
\hline & Weight $(\mathrm{g})$ & Guild & \multicolumn{2}{c}{ Density } \\
\cline { 4 - 5 } & & & $\begin{array}{c}\text { Bossematié } \\
\text { Forest }\end{array}$ & $\begin{array}{c}\text { Mature } \\
\text { rainforests }\end{array}$ \\
\hline Bleda eximia/notata & 48 & Und. ins. & 1.75 & c. $30^{* *}$ \\
Illadopsis rufescens & 37 & Und. ins. & 1.0 & $14-18^{* * *}$ \\
Apalis sharpei & 9 & Can. ins. & 5.50 & $?$ \\
Ceratogymna cylindricus/albotibialis & 921 & Can. frug. & 1.0 & $7.2 \pm 1.0^{*}$ \\
\hline
\end{tabular}




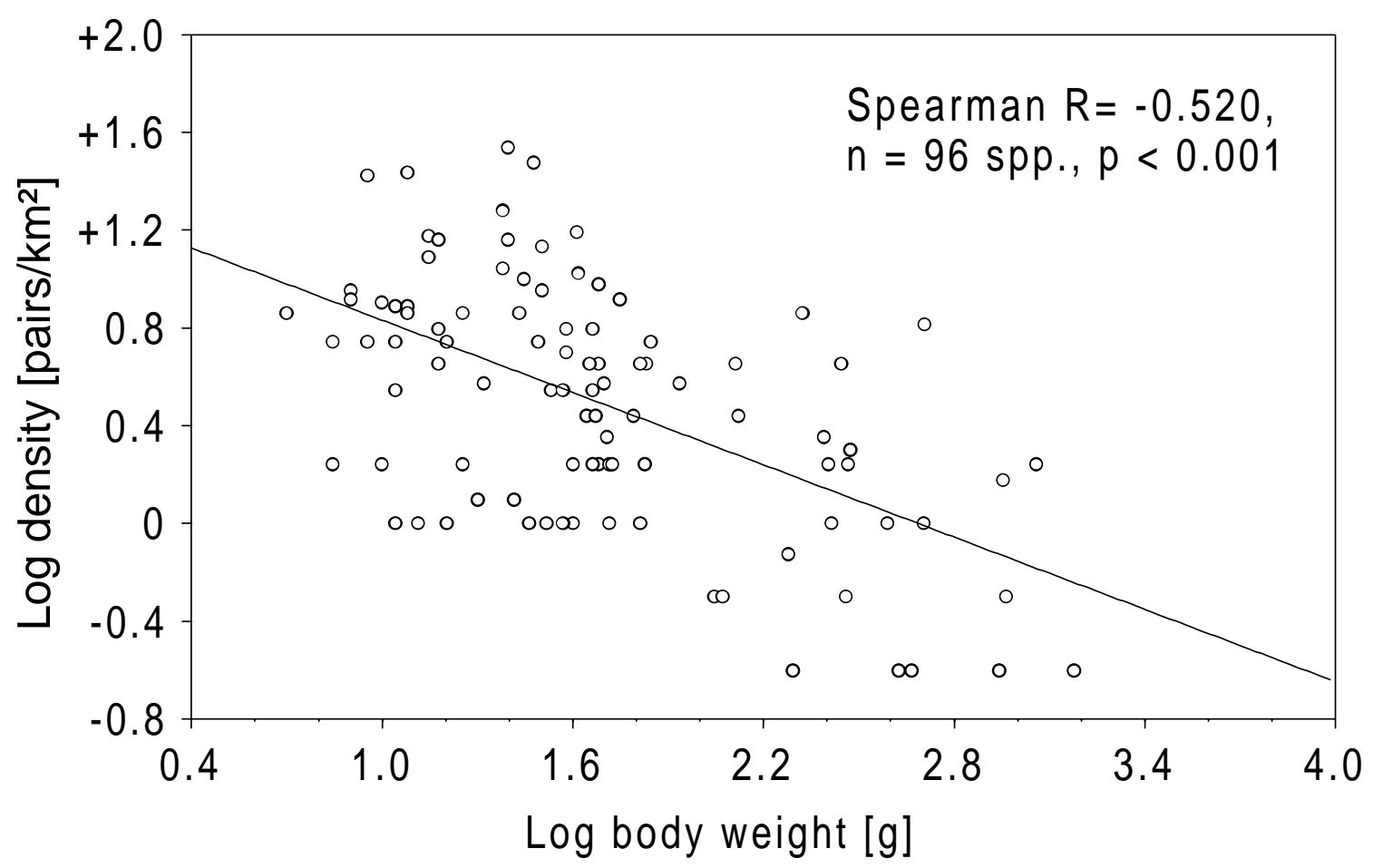

Fig. 14: Relationship between body weight and density in 96 bird species in a heavily logged rainforest in south-east Côte d'Ivoire. The four uppermost outliers are, in increasing weight order: Nectarinia olivacea (Nectariniidae), Hylia prasina (Sylviidae), Andropadus latirostris (Pycnonotidae) and Illadopsis fulvescens (Timaliidae).

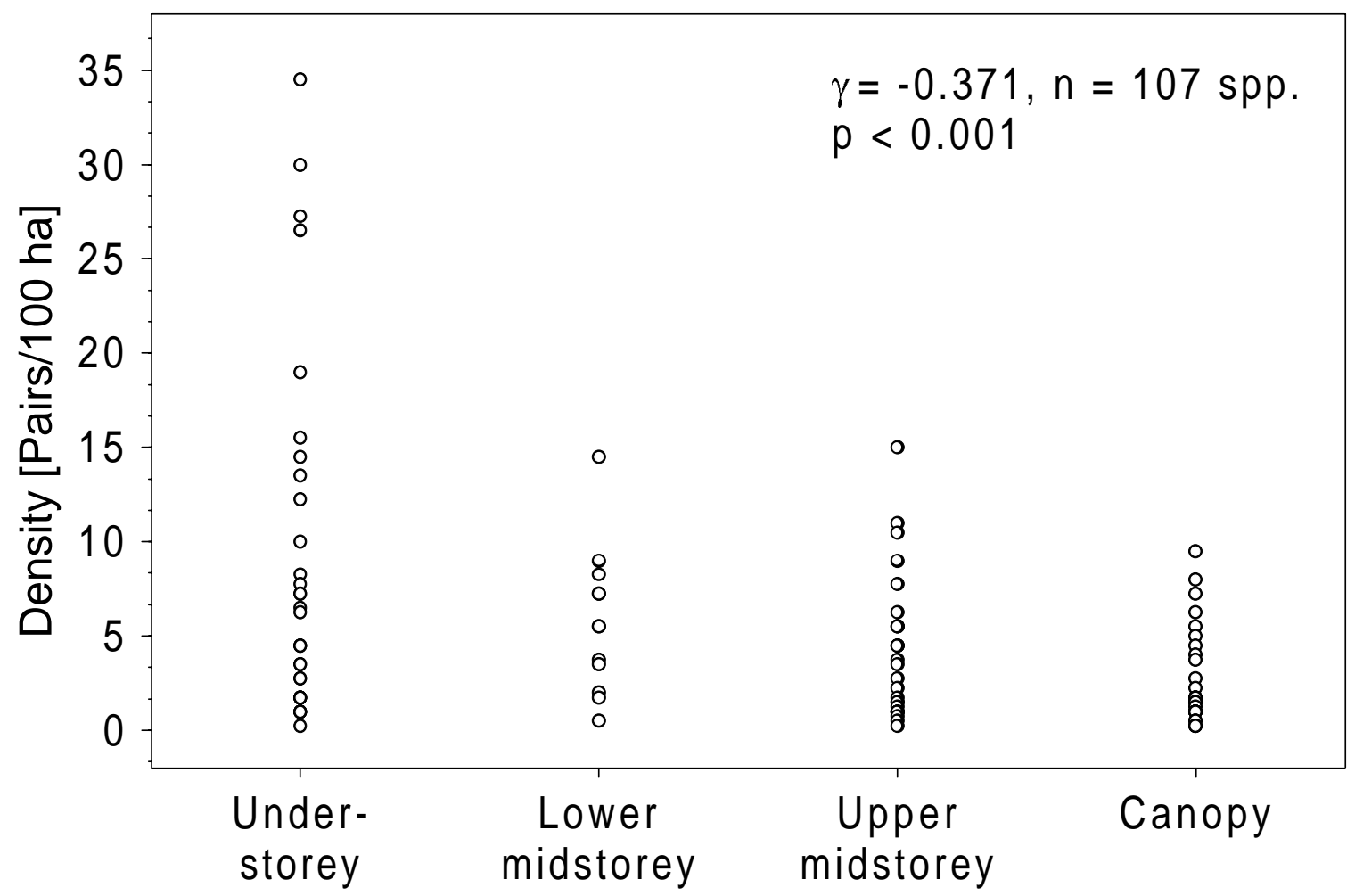

Fig. 15: Relationship between vertical foraging height and abundance in 107 spp. with a minimum density of 0.25 pairs/100 ha on a 110 ha plot in a heavily logged rainforest in south-east Côte d'Ivoire. The Gamma correlation coefficient $\gamma$ indicates a significant decrease in abundance with increasing foraging height. 


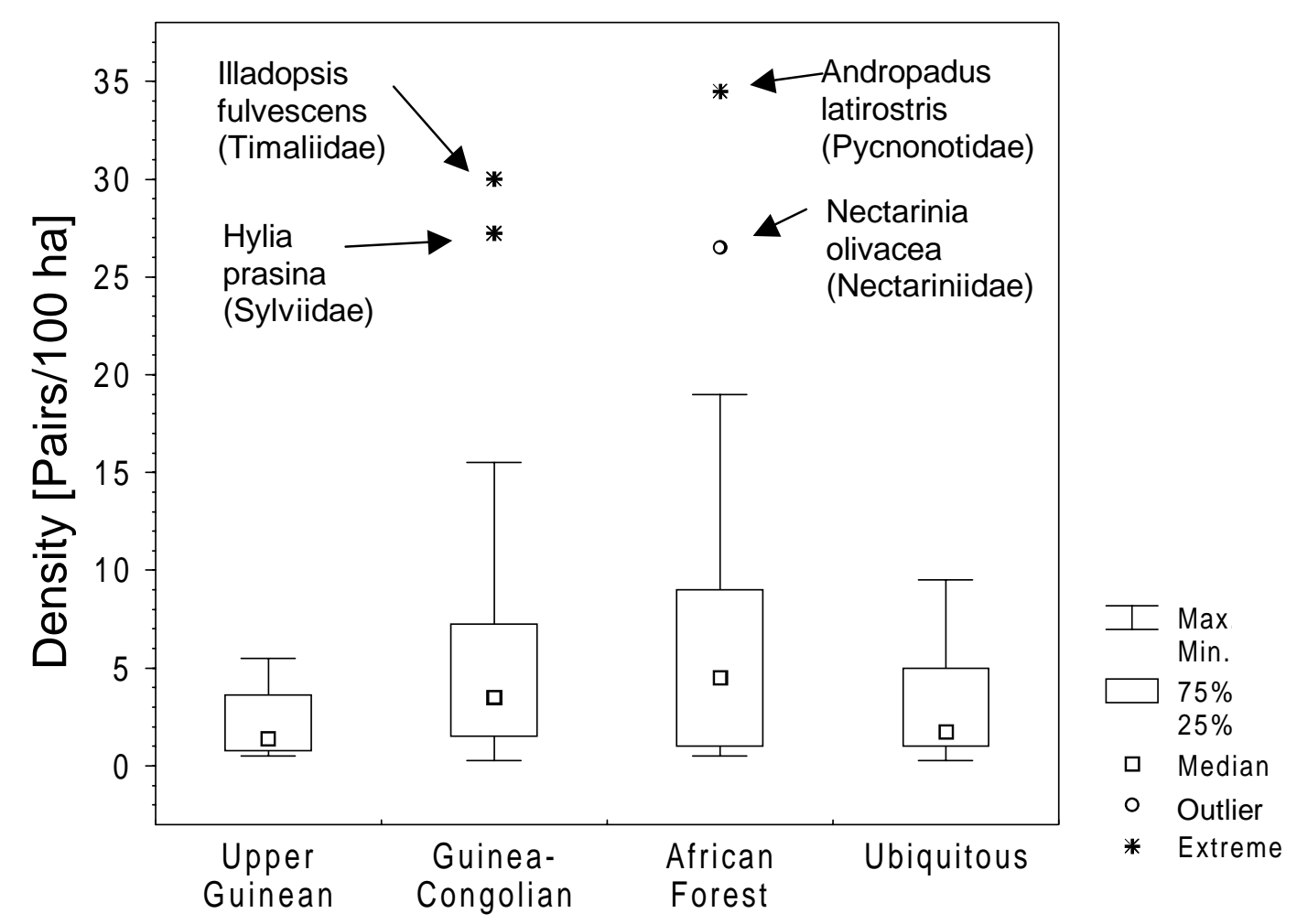

Fig. 16: Density distribution in 106 bird species with different geographic ranges on a 110 ha study plot in a heavily logged rainforest in south-east Côte d'Ivoire. Only species with a minimum density of 0.25 pairs/100 ha are included. Upper Guinean $n=4$ spp., Guinea-Congolian $n=88$ spp., African Forest $n=25$ spp., Ubiquitous n= 18 spp.

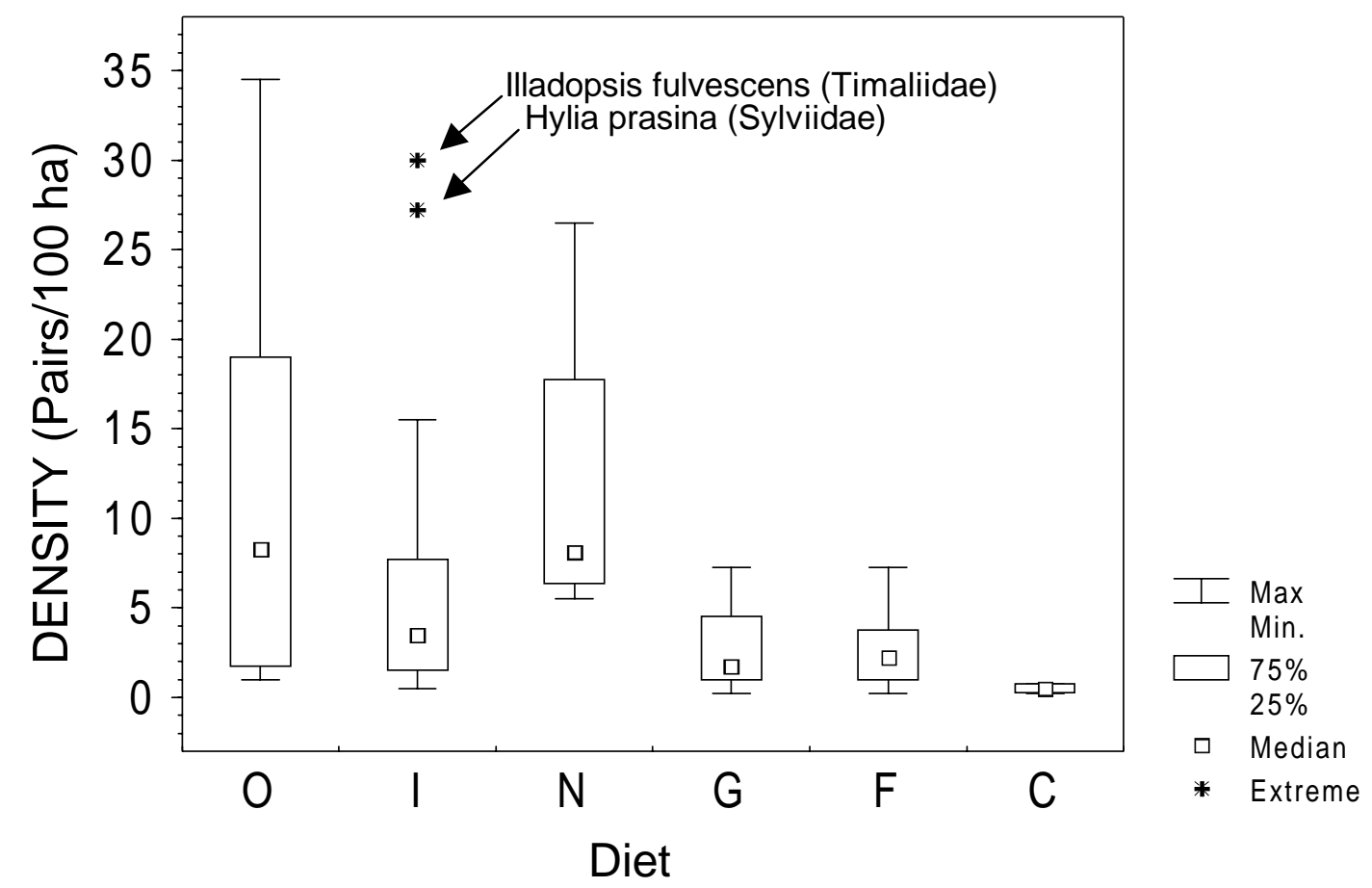

Fig. 17: Abundance distribution of species of different diet guilds in a 110 ha plot in a heavily logged rainforest in south-east Côte d'Ivoire. Only the $107 \mathrm{spp}$. with a minimum density of 0.25 pairs/100 ha are included. O - omnivorous (6 spp.), I - insectivorous (67 spp.), N - nectarivorous (4 spp.), G - granivorous (11 spp.), F - frugivorous (17 spp.), C - carnivorous (2 spp.) 


\subsubsection{Mixed foraging flocks}

Mixed foraging flocks (bird parties) were defined as feeding groups of birds of two or more species moving through the vegetation together as a loose flock. They may include a variety of species feeding in different ways and at different heights, or they may be small feeding only in one layer of the vegetation. There are several theories explaining the advantages for birds joining bird parties, e.g. they can better locate insect food because of the disturbance created or gain more protection against predators (Brosset 1969, Croxall 1976).

In total, 50 mixed feeding flocks were recorded in the Bossematie area. All of them were recorded within the borders of the Forêt Classée. Of these 50 flocks, 17 were recorded during standardised mapping on the 110 ha plot (see appendix D), another 33 were recorded extra, either on the plot or elsewhere in the Bossematié Forest. Most flocks were recorded in the control compartment (eleven during standardised mapping), and none were recorded in the plantation, but there was no overall significant difference in the frequency of occurrence between plantation, control, liberation thinning and swamp forest area (Chi-sq. test, $\chi^{2}{ }_{3 \mathrm{df}}=$ $3.33, \mathrm{p}=0.433)$.

The 50 flocks comprised a total of 350 identified individuals in 63 species from 23 families. Most species (90\%) were insectivorous species. Three nectarivores (partially insectivorous Nectariniidae), two frugivores (a barbet, Tricholaema hirsuta, and a hornbill, Tockus semifasciatus) and the granivorous Ahanta Francolin Francolinus ahantensis, were also recorded. Four species were encountered in more than $30 \%$ of the flocks: two pycnonotids, White-bearded Greenbul Criniger calurus, and the Cameroon Sombre Greenbul Andropadus curvirostris, the platysteirid flycatcher Diaphorophyia castanea, and the forest weaver Malimbus rubricollis. Five more species were encountered in $20-30 \%$ of the flocks: two sylviids, Grey Longbill Macrosphenus concolor and the Yellow-browed Camaroptera Camaroptera superciliaris, as well as White-throated Greenbul Phyllastrephus albigularis, Fraser's Scarlet-tufted Sunbird Anthreptes fraseri and the Yellow-bill Ceuthmochares aereus, a non-parasitic cuculid. seventeen more species from eleven families were encountered in 10 $20 \%$ of the flocks, but 37 species (more than half of the 63 species) were only encountered in less than $10 \%$ of the flocks.

\subsubsection{General composition}

Most flocks (39 of 50, or $78 \%$ ) comprised less than ten species, the mean being $6.9( \pm 4.6)$ species per flock. However, eleven flocks still consisted of ten or more species, the largest flock containing at least 24 species. The size of the flocks amounted up to 30 individuals, but most flocks were between five and fourteen individuals, giving a mean of $10.9( \pm 7.3)$. Species from all vertical strata were present, but especially midstorey species were represented by a higher number of species and in both understorey and canopy species, a lower number of species showed flocking behaviour (Chi-sq. test, $\chi^{2}{ }_{3 \mathrm{df}}=8.41, \mathrm{p}=0.038$ ). However, there was a statistically significant relationship between the species' preferred foraging stratum and the 
frequency of occurrence in flocks. The Gamma rank correlation coefficient $\gamma$ indicated a weak negative correlation between foraging height and encounter frequency (\% flocks with respective species present). Whereas species of the lower strata tended to be more regular members of flocks, species of higher strata were less regularly encountered $(\gamma=-0.212, \mathrm{n}=63$ spp., $\mathrm{p}=0.0495)$. This relationship was only weak mainly because the most regularly encountered species were not true understorey, but lower midstorey species (White-bearded Greenbul Criniger calurus and Chestnut-Wattle-eye Diaphorophyia castanea).

Tab. 9: Distribution of species numbers and individuals encountered in $\mathbf{5 0}$ mixed bird parties in the Bossematié Forest, south-east Côte d'Ivoire.

\begin{tabular}{|c|c|c|c|c|c|}
\hline a) Species & $<5$ & $5-9$ & $10-14$ & $15-19$ & $20-24$ \\
\hline No. of flocks & 16 & 23 & 8 & 1 & 2 \\
\hline$\%$ & 32 & 46 & 16 & 2 & 4 \\
\hline \multicolumn{6}{|l|}{ mean $( \pm$ s.d. $)$} \\
\hline b) Individuals & $<5$ & $5-9$ & $10-14$ & $15-19$ & $>20$ \\
\hline No. of flocks & 8 & 16 & 13 & 8 & 5 \\
\hline$\%$ & 16 & 32. & 26 & 16 & 1 \\
\hline mean $( \pm$ s.d. $)$ & & & $10.9( \pm 7$ & & \\
\hline
\end{tabular}

\subsubsection{Interspecific associations}

It has been shown that obligate members of mixed flocks are especially vulnerable to logging (Thiollay 1992, 1994a). If logging in the Bossematié Forest affected the abundances of obligately flocking species, it can be assumed that flocks are more ill-defined associations of non-obligatory species. In the primary forest of Gola, Sierra Leone, the principal „core“ species of mixed species flocks are Icterine Greenbul Phyllastrephus icterinus, Shining Drongo Dicrurus atripennis and Fraser's Scarlet Tufted Sunbird Anthreptes fraseri. In the Bossematié Forest, however, Icterine Greenbul and the Shining Drongo were only recorded once and five times respectively (all observations made in flocks). Somewhat more frequent, but still not common, was Fraser's Scarlet tufted Sunbird, which was observed thirteen times in flocks (out of 19 total records). The species was one out of the eight most regularly encountered species (present in more than $20 \%$ of flocks) whose associations (number of flocks shared) are shown in Fig. 18. From these associations, three principal categories of flocks can be separated:

1) Understorey flocks, mainly composed of greenbuls Pycnonotidae, with the "core" species Red-tailed Greenbul Criniger calurus, Cameroon-Sombre Greenbul Andropadus curvirostris, and White-throated Greenbul Phyllastrephus albigularis. One more pycnonotid, the Grey-headed Bristlebill Bleda canicapilla, essentially belongs to this group, as well as the Brown Illadopsis (Timaliidae). A special kind of understorey association is that of ant-following species. In the Bossematie Forest, these species, whose respective habits are already well known, are the thrushes Fire-crest Alethe Alethe diademata, Forest Robin Stiphrornis erythrothorax, and White-tailed Ant-thrush Neocossyphus poensis. The Red-tailed Bristlebill Bleda syndactyla was also observed in several occasions, but antfollowing flocks were not encountered as regularly as the above mentioned association of not ant-following species. 
2) Midstorey flocks, with flycatchers and small foliage gleaning species dominating. The "core" species are Chestnut Wattle-eye Diaphorophyia castanea (Playtsteiridae) and Fraser's Scarlet-tufted Sunbird Anthreptes fraseri (Nectariniidae). Other flocking midstorey species are the monarchids Terpsiphone rufiventer and Trochocercus nitens, and the more infrequent members, Finsch's Flycatcher-thrush Neocossyphus finschii and the Red-billed Dwarf Hornbill Tockus camurus. Furthermore, there are species from both group (1) or (3) mixing in variable proportions with this group.

3) Midstorey/canopy flocks. This guild is both rich in species as heterogeneous in guilds. The "core" species are small foliage-gleaners such as Yellow-browed Camaroptera Camaroptera superciliaris, Grey Longbill Macrosphenus concolor or Sharpe's Apalis Apalis sharpii (Sylviidae), but a very regular member (in $37 \%$ of all flocks) is the ploceid Red-headed Malimbe Malimbus rubricollis. Less regular mixed flock members associated with canopy flocks are Yellow-bill Ceuthmochares aereus (Cuculidae), White-naped Weaver Ploceus albinucha, Western Black-headed Oriole Oriolus brachyrhynchus, Blue Cuckoo-shrike Coracina azurea, and the Drongo Dicrurus adsimilis, the three latter species being very vocal.

During the study, no associations between birds and mammals (Primates or Duikers) were observed.

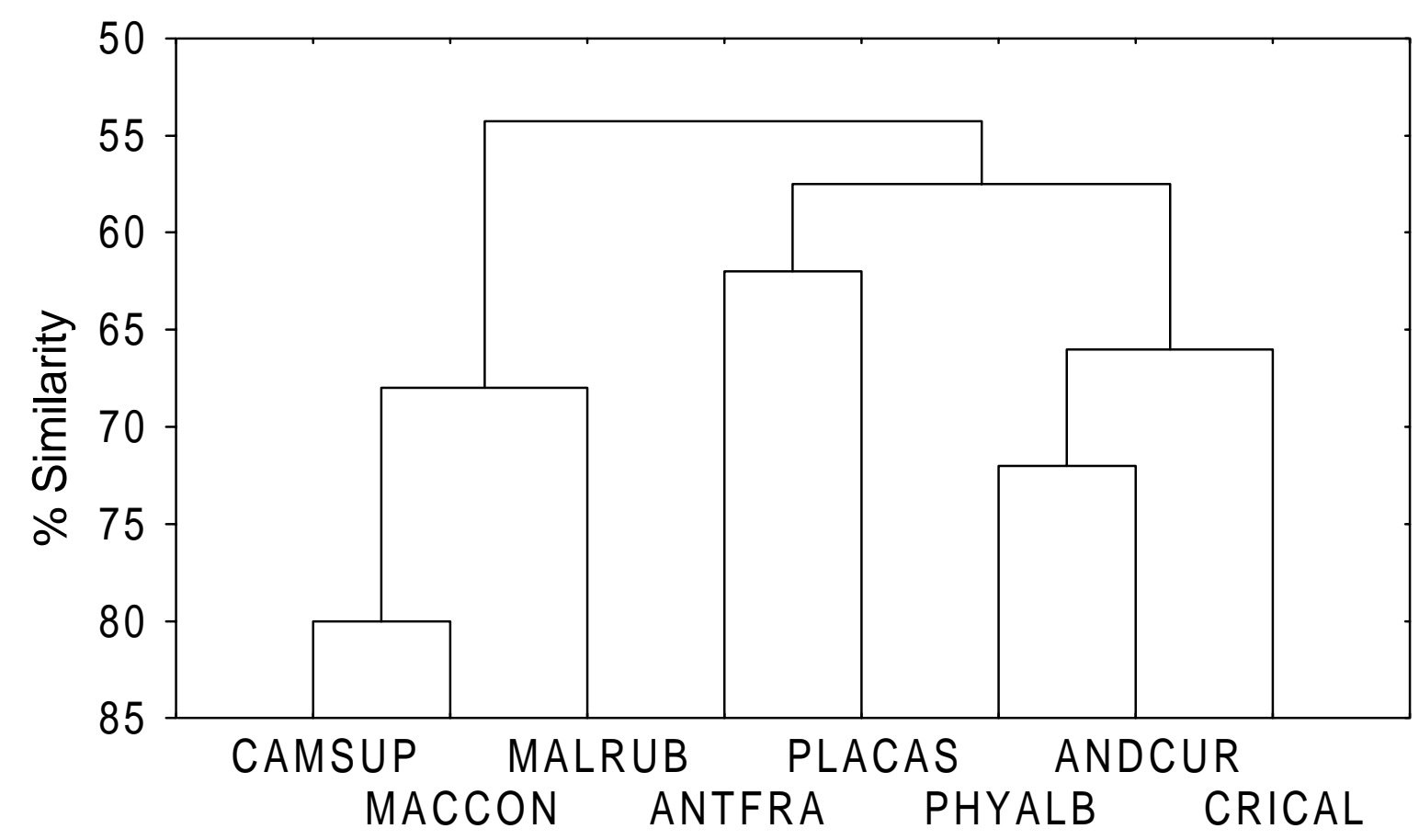

Fig. 18: Associations between the eight most frequent members of mixed flocks in a heavily degraded rainforest in south-east Côte d'Ivoire. Presence/absence data of 50 mixed flocks clustered using weighted pair group average clustering and \% non-overlap as distance measure (converted to similarity on y axis). Six-letter codes, from left: Camaroptera superciliaris, Macrosphenus concolor (Sylviidae), Malimbus rubricollis (Ploceidae), Anthreptes fraseri (Nectariniidae), Diaphorophyia castanea (syn.: Platysteira, Platysteridae), Phyllastrephus albigularis, Andropadus curvirostris, Criniger calurus (Pycnonotidae). 


\subsubsection{Management impact on the community}

The vegetation types (Tab. 1) are disproportionally distributed on the 110 ha plot. However, mapping data from each one of the six 18.3 ha sectors can be compared. Two sectors are essentially covering the control area, while only one complete sector was situated inside the liberation thinning area. One sector crosses both liberation thinning and control and two more sectors are mainly covered by swamp forest or plantation (see Fig. 10).

\subsubsection{Abundance, species richness and diversity}

Differences between control and liberation thinning. To analyse differences in bird communities between the control and the liberation thinning area, data from the two control sectors (both 18.3 ha) were compared with those from a liberation thinning sector (18.3 ha) and the complete liberation thinning area (32.1 ha). In this comparison, the maximum numbers of territorial individuals recorded within one of six separate censuses was used as a basis for the calculations.

Overall, the number of social groups, species richness and diversity appeared to be similar between control and liberation thinning. On the 18.3 ha-scale, about the same number of species $(\mathrm{S})$ were recorded in control and liberation thinning. The Shannon index $\left(\mathrm{H}_{\mathrm{s}}\right)$, and Evenness $\left(\mathrm{H}_{\mathrm{s}} / \mathrm{lnS}\right)$ did not differ either, but the proportion of singletons (\% of $\mathrm{S}$ ), Fisher's alpha index and species richness estimators (ACE, Chao1, see Colwell 1997) were higher for liberation thinning. On a larger scale (36.7 control compared to 32.1 ha liberation thinning), species richness, Shannon index, Evenness, Alpha index, and richness estimators seemed to be higher in control than liberation thinning, but this difference was only slight and could also be caused by the slightly larger surface ( 4.6 ha) covered in the control compartment (Tab. 10).

Tab. 10: Numbers of pairs (I), numbers of species (S), and diversity (Shannon $\mathbf{H}_{S}$, Fisher's alpha, Simpson after Magurran 1988, ACE and Chao1 after (Colwell 1997) of bird communities mapped in different sectors of a heavily logged rainforest, south-east Côte d'Ivoire. Calculations are based on maximum numbers of territorial individuals recorded within one of six separate censuses.

\begin{tabular}{|c|c|c|c|c|c|}
\hline & \multicolumn{3}{|c|}{ Control } & \multicolumn{2}{|c|}{ Liberation thinning } \\
\hline & $\begin{array}{c}\text { Sector a } \\
(18.3 \mathrm{ha})\end{array}$ & $\begin{array}{l}\text { Sector d } \\
(18.3 \mathrm{ha})\end{array}$ & $\begin{array}{c}\text { Sectors a +d } \\
(36.7 \mathrm{ha})\end{array}$ & $\begin{array}{c}\text { Sector f } \\
(18.3 \mathrm{ha})\end{array}$ & $\begin{array}{c}\text { Sectors f+e } \\
(32.1 \mathrm{ha})\end{array}$ \\
\hline Number of pairs (I) & 170 & 160 & 320 & 143 & 302 \\
\hline Species $(\mathrm{S})$ & 72 & 71 & 86 & 72 & 81 \\
\hline Singletons (\% of $\mathrm{S})$ & 43.1 & 43.7 & 29.1 & 52.8 & 32.1 \\
\hline Diversity (Hs) & 4.05 & 4.04 & 4.14 & 4.00 & 3.97 \\
\hline Evenness (Hs/lnS) & 0.95 & 0.95 & 0.93 & 0.94 & 0.90 \\
\hline Diversity (alpha) & $47.14( \pm 5.9)$ & $48.9( \pm 6.4)$ & $38.6( \pm 3.4)$ & $57.8( \pm 8.2)$ & $36.3( \pm 3.3)$ \\
\hline Diversity (Simpson 1/D) & 65 & 65.2 & 57.4 & 50.8 & 41.6 \\
\hline $\mathrm{ACE}$ & 101.5 & 101.5 & 105.2 & 119.4 & 100.8 \\
\hline Chao1 & $98.7( \pm 12.6)$ & $96.3( \pm 11.9)$ & $106.8( \pm 11.0)$ & $104.8( \pm 14.0)$ & $98.8( \pm 9.1)$ \\
\hline
\end{tabular}

Differences between control, swamp forest and plantation. Although the swamp forest area (13.2 ha) and the plantation (12.7 ha) represented only a small part of the total study plot size, numbers of social groups/pairs and species recorded were remarkably high. In the 13.2 ha swamp forest area, the number of social groups/pairs (202) was 1.7 times and the number of 
species (76) was 1.5 times higher as expected from numbers and species richness found on the 18.3 ha control sectors. In contrast, differences between the control sectors and the 12.7 ha plantation were not that pronounced, the number of social groups/pairs was only 1.3 times higher and the number of species 1.1 times higher than expected from values found in control sectors. However, it should be considered that the plantation and the swamp forest are relatively small areas, so that territories of many species overlapped between vegetation types.

A better understanding of community patterns in the plantation and swamp forest area is obtained, when comparing the censused sectors of similar size, although, as mentioned above, sectors sometimes contained more than one vegetation type. Tab. 11 shows the diversity data of 18.3 ha sectors dominated by the vegetation types swamp forest and plantation in comparison with the two control sectors. It is evident that all sectors show more or less equal numbers of pairs and species. Sector b, covering parts of the control compartment and the Terminalia plantation, had a slightly elevated number of species (75 spp.) compared to sector a (control, 72 spp.). The Shannon index and Fisher's alpha were also somewhat higher, but evenness and estimated size of the local species pool (ACE, Chao1) were about the same. Sector c (Swamp Forest - Plantation) showed a slightly lower number of pairs recorded, but species richness, diversity, evenness or estimators of total species richness were similar compared to control.

Tab. 11: Number of pairs (I), number of species (S), and diversity (Shannon $H_{S}$, Fisher's alpha, Simpson and Berger Parker after Magurran 1988, ACE and Chao1 after Colwell 1997) of bird communities mapped in $\mathbf{1 8 . 3}$ ha sectors of different vegetation types in a heavily logged rainforest, south-east Côte d'Ivoire. Calculations are based on maximum numbers of territorial individuals recorded within one of six separate spot-mapping censuses.

\begin{tabular}{|c|c|c|c|c|}
\hline & \multicolumn{2}{|c|}{ Control } & \multirow{2}{*}{$\frac{\text { Plantation-Control }}{\text { Sector b }}$} & \multirow{2}{*}{$\frac{\text { Swamp-Plantation }}{\text { Sector c }}$} \\
\hline & Sector a & Sector $\mathrm{d}$ & & \\
\hline Number of pairs (I) & 170 & 160 & 172 & 148 \\
\hline Species (S) & 72 & 71 & 75 & 71 \\
\hline Singletons (\% of S) & 43.1 & 43.7 & 41.3 & 45.1 \\
\hline Diversity (Hs) & 4.05 & 4.04 & 4.10 & 4.08 \\
\hline Evenness (Hs/lnS) & 0.95 & 0.95 & 0.95 & 0.96 \\
\hline Diversity (alpha) & $47.14( \pm 5.89)$ & $48.9( \pm 6.4)$ & $50.7( \pm 6.3)$ & $53.6( \pm 7.4)$ \\
\hline Diversity (Simpson 1/D) & 65 & 65.2 & 66.9 & 75.0 \\
\hline Diversity (Berger Parker 1/d) & 20.6 & 17.3 & 15.3 & 18.1 \\
\hline ACE & 101.5 & 101.5 & 99.3 & 99.1 \\
\hline Chao1 & $98.7( \pm 12.6)$ & $96.3( \pm 11.9)$ & $101.7( \pm 12.6)$ & $99.4( \pm 13.2)$ \\
\hline
\end{tabular}

\subsubsection{Abundance rank patterns}

The distribution of pair abundance in the different 18.3 ha sectors of the 110 ha plot did not differ significantly from (truncated) log-normal nor log-series distributions ( $\chi^{2}$ Goodness of fit tests, all $\mathrm{p}>0.1)$. The corresponding rank abundance patterns are shown in Fig. 19. 


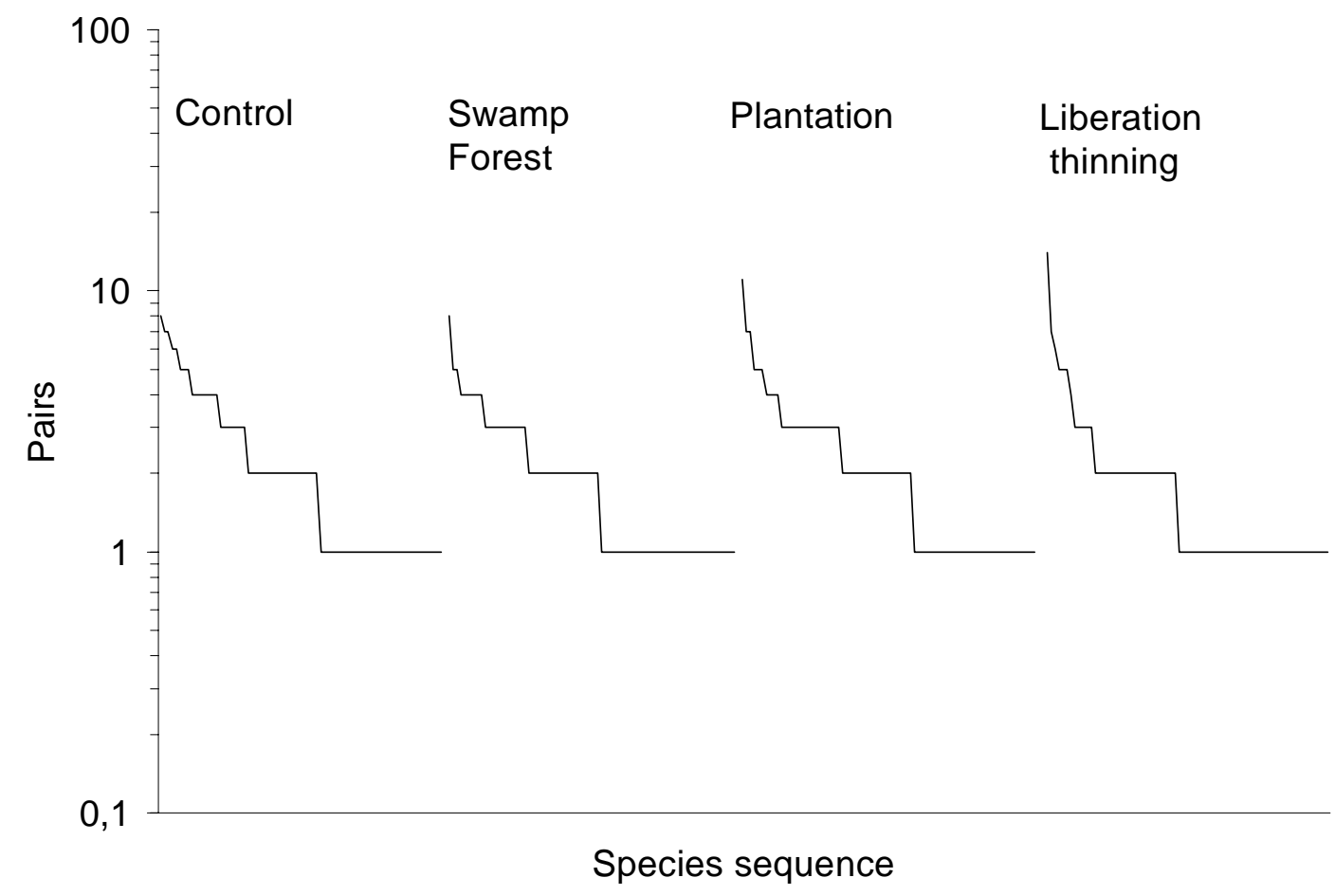

Fig. 19: Rank abundance plots showing the diversity of bird species in four $\mathbf{1 8 . 3}$ ha sectors with different vegetation types on a 110 ha study plot of a heavily degraded rainforest in south-east Côte d'Ivoire.

\subsubsection{Species composition}

Species composition was most similar between the two control sectors (Morisita-Horn index of species similarity $=0.89$ ), but similarity was still high between the two control sectors and the partly liberation thinned sector e (see Fig. 10), 0.86 and 0.88 respectively. A still high, but already lower, similarity was visible between the sector completely liberation thinned (sector $\mathrm{f}$ ) and the two control sectors ( 0.81 and 0.80 respectively). The two control sectors were most distant from swamp forest and plantation sectors (Morisita Horn indices of 0.70 and 0.76). These were, in turn, more similar to each other (0.88). The described relationships are also visible when clustering average group distances between the different sectors as shown in the dendrogram of Fig. 20. 


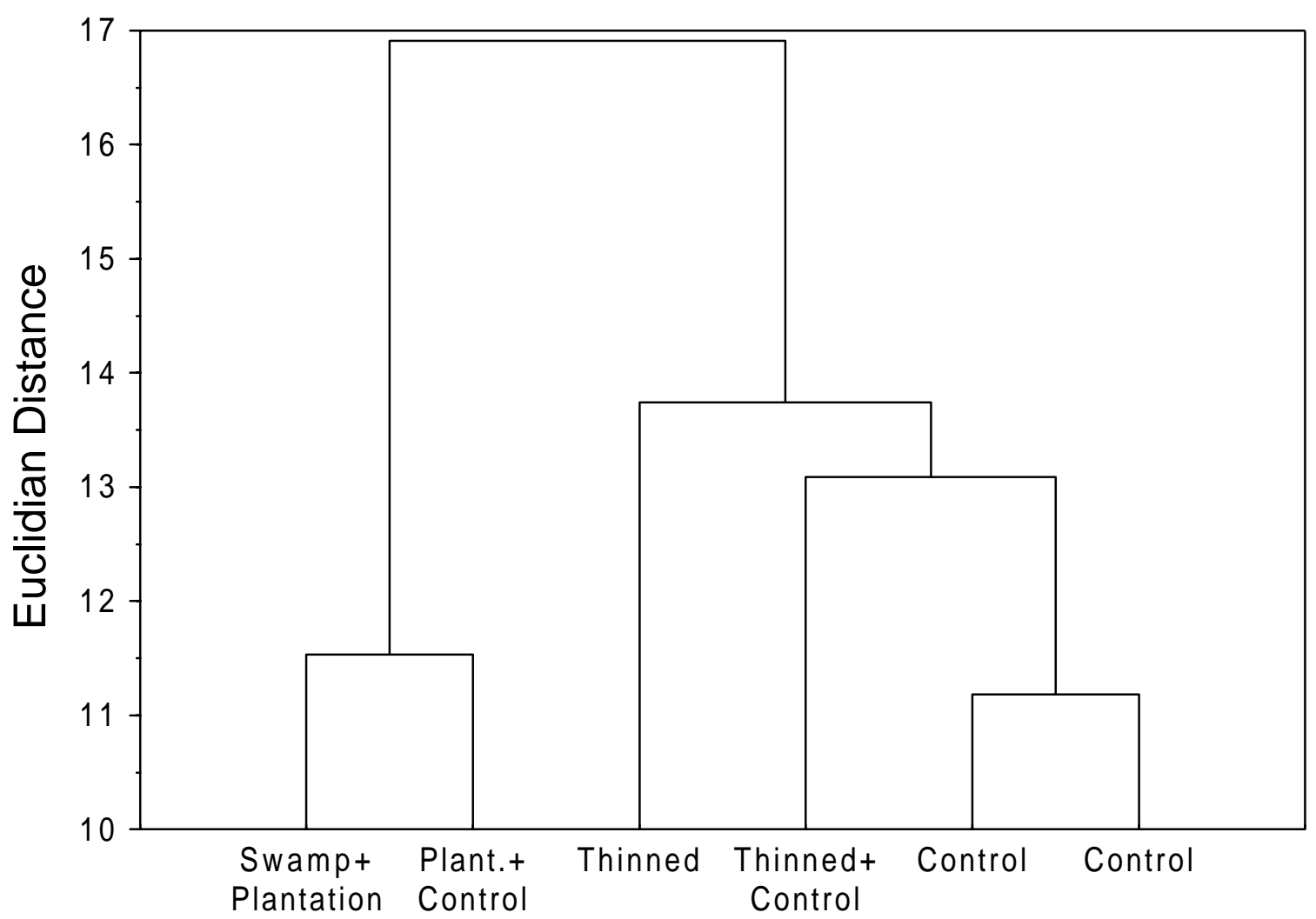

Fig. 20: Turnover in bird species composition of six 18.3 ha-sectors within a 110 ha plot of a heavily logged rainforest in south-east Côte d'Ivoire. The sectors are constituted as a whole or partly of the following vegetation types: Swamp - heavily degraded swamp forest; Plant. - five-years old Terminaliaplantation, Thinned - liberation thinning area, Control - control area.

\subsubsection{Interspecific comparisons of habitat preferences}

\section{Control vs. liberation thinning}

For a detailed comparison of habitat preferences between the control and the liberation thinning area, for each species the number of pairs found in two 18.3 ha sectors (sector $\mathrm{d}$ and $\mathrm{f}$, see Fig. 10) were compared. Most densities were too low to conduct detailed statistical analyses of habitat selection on the species level. E.g. in the liberation thinning sector, $54 \%$ of the species were recorded as single pairs, $30 \%$ as doubletons and only six species (1\%) were present in five or more pairs. Therefore, species were grouped into one of the following three classes: (1) species with a higher number of pairs in control, (2) species with a higher number of pairs in liberation thinning, or (3) species with the same number of pairs in both sectors. Then, group (1) was tested against group (2) with the help of the Chi-sq. test.

The results show that of the 90 species recorded in these two sectors, 37 species (41\%) were less abundant (maximum number of pairs recorded) in the liberation thinning sector, while 32 (36\%) were more abundant and 21 species (23\%) equally abundant in both sectors. GuineaCongolian species were found to have considerable proportions of species with a preference for both the control and the liberation thinning sector. In African Forest species, more species than expected preferred the liberation thinning than the control sector, although this was not 
significant on the 5\% level (Tab. 12a). There were no obvious differences in the respective proportions of species from different weight classes (Tab. 12b). Although in small species there were more species than expected with a higher abundance in control, and in large species more with a higher abundance in liberation thinning, there was no significant proportional difference ( $2 \times 2$ table, $\left.\chi^{2}{ }_{1 \mathrm{df}}=2.53, \mathrm{p}=0.112\right)$. There were no statistically significant differences in the respective distributions among understorey or midstorey species, but there was a clear tendency in canopy species. For the canopy species, a larger proportion than expected was encountered in the liberation thinning sector (Tab. 12d). Frugivores, granivores, nectarivores and omnivores all had a higher proportion of species with preferences for liberation thinning and were therefore lumped for analysis. The distributional differences were significant $\left(\chi^{2}{ }_{1 \mathrm{df}}=5.50, \mathrm{p}=0.019\right)$. There was no such statistically significant distribution among the insectivorous species $\left(\chi^{2}{ }_{1 \mathrm{df}}=2.22, \mathrm{p}=0.136\right)$.

Tab. 12 a-d: Distribution of bird species of different (a) geographic range, (b) weight classes, (c) diet, and (d) preferred vertical stratum in a control and a liberation thinning sector (each of 18.3 ha size) in a degraded rainforest in south-east Côte d'Ivoire. The species are grouped to the sector where a higher number of pairs were recorded. The expected distribution was calculated according to the general distribution of species between habitats. Observed (Obs.) and expected (Exp.) frequencies were compared using chi-square test.

\begin{tabular}{|c|c|c|c|c|c|c|c|c|c|}
\hline \multicolumn{2}{|c|}{ (a) Geographic range } & \multicolumn{2}{|c|}{ Upper Guinean } & \multicolumn{2}{|c|}{ Guinea-Congolian } & \multicolumn{2}{|c|}{ African Forest } & \multicolumn{2}{|c|}{ Ubiquitous } \\
\hline & & Obs. & Exp. & Obs. & Exp. & Obs. & Exp. & Obs. & Exp. \\
\hline \multirow{2}{*}{$\begin{array}{l}\text { Higher } \\
\text { abund. } \\
\text { in }\end{array}$} & Control & 1 & 1.6 & 28 & 25.4 & 4 & 7.0 & 4 & 2.7 \\
\hline & $\begin{array}{l}\text { Liberation } \\
\text { thinning }\end{array}$ & 2 & 1.4 & 19 & 21.6 & 9 & 6.0 & 1 & 2.3 \\
\hline \multicolumn{2}{|l|}{$\chi^{2}$} & & & \multicolumn{2}{|c|}{0.58} & \multicolumn{2}{|c|}{2.79} & & \\
\hline
\end{tabular}

\begin{tabular}{|c|c|c|c|c|c|}
\hline \multicolumn{2}{|c|}{$\begin{array}{l}\text { (b) Body Size } \\
\text { (Weight) }\end{array}$} & \multicolumn{2}{|c|}{$\begin{array}{l}\text { Small to } \\
\text { medium } \\
(<64 \mathrm{~g})\end{array}$} & \multicolumn{2}{|c|}{$\frac{\text { Large }}{(64-2048 \mathrm{~g})}$} \\
\hline & & Obs. & Exp & Obs. & Exp. \\
\hline \multirow{2}{*}{$\begin{array}{l}\text { Higher } \\
\text { abund. } \\
\text { in }\end{array}$} & Control & 28 & 25.1 & 7 & 9.7 \\
\hline & $\begin{array}{l}\text { Liberation } \\
\text { thinning }\end{array}$ & 16 & 18.9 & 10 & 7.3 \\
\hline \multicolumn{2}{|l|}{$\chi^{2}$} & \multicolumn{2}{|c|}{0.78} & \multicolumn{2}{|c|}{1.75} \\
\hline
\end{tabular}

\begin{tabular}{|c|c|c|c|c|}
\hline \multirow[t]{3}{*}{ (c) Diet } & \multirow{2}{*}{\multicolumn{2}{|c|}{$\begin{array}{l}\text { Frug. (13 spp.) + gran. (6 } \\
\text { spp.) + nect.(5 spp.)+ } \\
\text { omn. (4 spp.) }\end{array}$}} & \multicolumn{2}{|c|}{ Insectivores } \\
\hline & & & \multirow[b]{2}{*}{ Obs. } & \multirow[b]{2}{*}{ Exp. } \\
\hline & Obs. & Exp. & & \\
\hline & 5 & 10.1 & 30 & 24.9 \\
\hline & 14 & 8.9 & 17 & 22.1 \\
\hline & \multicolumn{2}{|c|}{5.50} & \multicolumn{2}{|c|}{0.136} \\
\hline
\end{tabular}

\begin{tabular}{|c|c|c|c|c|c|c|c|c|c|}
\hline \multirow{2}{*}{\multicolumn{2}{|c|}{ (d) Vertical stratum }} & \multicolumn{2}{|c|}{$\begin{array}{c}\text { Under- } \\
\text { storey } \\
\end{array}$} & \multicolumn{2}{|c|}{$\begin{array}{c}\text { Lower } \\
\text { midstorey }\end{array}$} & \multicolumn{2}{|c|}{$\begin{array}{c}\text { Upper } \\
\text { midstorey }\end{array}$} & \multicolumn{2}{|c|}{ Canopy } \\
\hline & & Obs. & Exp. & Obs. & Exp. & Obs. & Exp. & Obs. & Exp \\
\hline \multirow{2}{*}{$\begin{array}{l}\text { Higher } \\
\text { abund. } \\
\text { in }\end{array}$} & Control & 12 & 11.9 & 5 & 4.3 & 14 & 11.3 & 6 & 9.7 \\
\hline & $\begin{array}{l}\text { Liberation } \\
\text { thinning }\end{array}$ & 10 & 10.1 & 3 & 3.7 & 7 & 9.7 & 12 & 8.3 \\
\hline \multirow{2}{*}{\multicolumn{2}{|c|}{$\begin{array}{l}\chi^{2} \\
P\end{array}$}} & \multicolumn{2}{|c|}{0.00} & \multicolumn{2}{|c|}{0.25} & \multicolumn{2}{|c|}{1.40} & \multicolumn{2}{|c|}{3.06} \\
\hline & & \multicolumn{2}{|c|}{$>0.5$} & \multicolumn{2}{|c|}{$>0.5$} & \multicolumn{2}{|c|}{0.237} & \multicolumn{2}{|c|}{0.080} \\
\hline
\end{tabular}




\section{Comparisons between all vegetation types}

To include plantation and swamp forest in the comparison, densities for all vegetation types were calculated as number of pairs per 10 ha. Then, species were grouped according to the vegetation type where the highest density was recorded. There was no difference in proportions of numbers of species preferring the respective vegetation types (Chi-sq. test, $\chi^{2}{ }_{3 \mathrm{df}}=6.14,0.105$, see totals in Tab. 13). Among the two most species-rich families, the greenbuls Pycnonotidae and warblers Sylviidae, significant differences in proportions between vegetation types were visible for Pycnonotidae, who were more likely to prefer the control compartment, but not for Sylviidae (Tab. 13).

Tab. 13: Distribution of greenbul (Pycnonotidae) and warbler (Sylviidae) species according to their habitat preferences (highest density) for the principal vegetation types in a 110 ha study plot of a heavily logged rainforest in south-east Côte d'Ivoire. The expected distributions were calculated according to the general distribution of the species (totals). Observed (Obs.) and expected (Exp.) frequencies were compared using a chi-square test.

\begin{tabular}{|c|c|c|c|c|c|c|}
\hline & \multicolumn{2}{|c|}{ Pycnonotidae } & \multicolumn{2}{|c|}{ Sylviidae } & \multirow[b]{2}{*}{ Tota } \\
\hline & & Obs. & Exp. & Obs. & Exp. & \\
\hline \multirow{4}{*}{$\begin{array}{l}\text { Highest } \\
\text { abun- } \\
\text { dance } \\
\text { in }\end{array}$} & Control & 7 & 3.5 & 1 & 2.4 & \multirow{4}{*}{$\begin{array}{l}26 \\
21 \\
32 \\
39\end{array}$} \\
\hline & Liberation thinning & 3 & 2.8 & 4 & 2.0 & \\
\hline & Swamp Forest & 0 & 4.3 & 2 & 3.0 & \\
\hline & Plantation & 6 & 5.3 & 4 & 3.6 & \\
\hline \multicolumn{2}{|l|}{$\chi^{2}$} & \multicolumn{2}{|c|}{7.86} & \multicolumn{2}{|c|}{3.19} & \\
\hline
\end{tabular}

Tab. 14a-d shows the distribution of the species with preferences for a certain vegetation type according to certain ecological characteristics. In this comparison, the above mentioned trend in the African Forest species visible on the 18.3 ha level was confirmed. Whereas more African Forest species than expected showed preferences for the plantation and the liberation thinning area, fewer species preferred the control or the swamp forest area (Chi-sq. test, $\chi^{2} 3 \mathrm{df}=6.64, \mathrm{p}=$ 0.084, Tab. 14). The distribution of ubiquitous species was even more pronounced. Most ubiquitous species preferred the plantation, the vegetation type differring most from natural forest. The observed distribution in this group was significantly different from the expected (Chi-sq. test, $\chi_{3 \mathrm{df}}=10.86, \mathrm{p}=0.013$ ). In contrast to these interesting distributions of species from different geographic ranges, the characteristics body size, foraging height or diet were apparently not a determining factor for the distribution of species among vegetation types (Tab. 14b,c,d). 
Tab. 14 a-d: Distribution of bird species with habitat preferences (highest density) for the principal vegetation types on a 110 ha study plot in a heavily logged rainforest in south-east Côte d'Ivoire. The species are grouped according to (a) geographic range, (b) weight, (c) diet and (d) preferred vertical stratum. The expected distributions were calculated according to the general distribution of species between the vegetation types (see Tab. 13). Observed (Obs.) and expected (Exp.) frequencies were compared using a chi-square test.

\begin{tabular}{|c|c|c|c|c|c|c|c|c|c|}
\hline \multirow{2}{*}{\multicolumn{2}{|c|}{ (a) Geographic range }} & \multicolumn{2}{|c|}{ Upper Guinean } & \multicolumn{2}{|c|}{ Guinea-Congolian } & \multicolumn{2}{|c|}{ African Forest } & \multicolumn{2}{|c|}{ Ubiquitous } \\
\hline & & Obs. & Exp. & Obs. & Exp. & Obs. & Exp. & Obs. & Exp. \\
\hline \multirow{4}{*}{$\begin{array}{l}\text { Highest } \\
\text { abun- } \\
\text { dance } \\
\text { in }\end{array}$} & Control & 2 & 0.9 & 20 & 17.1 & 3 & 4.7 & 1 & 3.3 \\
\hline & Liberation thinning & 1 & 0.7 & 10 & 13.2 & 8 & 3.6 & 1 & 2.6 \\
\hline & Swamp Forest & 0 & 1.1 & 26 & 21.1 & 4 & 5.7 & 2 & 4.1 \\
\hline & Plantation & 1 & 1.3 & 21 & 25.6 & 6 & 7.0 & 11 & 5.0 \\
\hline \multicolumn{2}{|l|}{$\begin{array}{l}\chi^{2} \\
P\end{array}$} & & & \multicolumn{2}{|c|}{4.13} & \multicolumn{2}{|c|}{6.64} & \multicolumn{2}{|c|}{10.86} \\
\hline
\end{tabular}

\begin{tabular}{|c|c|c|c|c|c|c|c|}
\hline \multirow{3}{*}{\multicolumn{2}{|c|}{ (b) Body size (Weight) }} & \multirow{2}{*}{\multicolumn{2}{|c|}{$\begin{array}{c}\text { Small } \\
(<16 \mathrm{~g})\end{array}$}} & \multirow{2}{*}{\multicolumn{2}{|c|}{$\begin{array}{c}\text { Medium } \\
(16-64 \mathrm{~g})\end{array}$}} & \multirow{2}{*}{\multicolumn{2}{|c|}{$\frac{\text { Large }}{(64-2048 \text { g) }}$}} \\
\hline & & & & & & & \\
\hline & & \multirow{2}{*}{$\begin{array}{c}\text { Obs. } \\
2\end{array}$} & \multirow{2}{*}{$\frac{\text { Exp. }}{5.0}$} & \multirow{2}{*}{$\frac{\text { Obs. }}{14}$} & \multirow{2}{*}{$\begin{array}{c}\text { Exp. } \\
9.4\end{array}$} & \multirow{2}{*}{$\begin{array}{c}\text { Obs. } \\
5\end{array}$} & \multirow{2}{*}{$\frac{\text { Exp }}{6.6}$} \\
\hline Highest & Control & & & & & & \\
\hline $\begin{array}{l}\text { abun- } \\
\text { dance }\end{array}$ & Liberation thinning & 8 & 4.8 & 6 & 8.9 & 6 & 6.3 \\
\hline & Swamp Forest & 7 & 6.7 & 12 & 12.7 & 9 & 8.9 \\
\hline & Plantation & 8 & 8.5 & 15 & 16.0 & 13 & 11.2 \\
\hline \multicolumn{2}{|l|}{$\begin{array}{l}\chi^{2} \\
P\end{array}$} & \multicolumn{2}{|c|}{3.98} & \multicolumn{2}{|c|}{3.28} & 0.69 & $>0.5$ \\
\hline
\end{tabular}

\begin{tabular}{|c|c|c|c|c|c|c|c|c|c|}
\hline \multirow{2}{*}{\multicolumn{2}{|c|}{ (c) Diet }} & \multicolumn{2}{|c|}{ Frugivores } & \multicolumn{2}{|c|}{ Granivores } & \multicolumn{2}{|c|}{ Insectivores } & \multicolumn{2}{|c|}{ Others } \\
\hline & & Obs. & Exp. & Obs. & Exp. & Obs. & Exp. & Obs. & Exp. \\
\hline \multirow{4}{*}{$\begin{array}{l}\text { Highest } \\
\text { abun- } \\
\text { dance } \\
\text { in }\end{array}$} & Control & 1 & 3.7 & 0 & 2.6 & 21 & 16.5 & 4 & 3.1 \\
\hline & Liberation thinning & 3 & 3.1 & 3 & 2.2 & 11 & 13.5 & 4 & 2.5 \\
\hline & Swamp Forest & 4 & 4.6 & 5 & 3.2 & 22 & 20.3 & 1 & 3.8 \\
\hline & Plantation & 9 & 5.6 & 4 & 4.0 & 21 & 24.8 & 5 & 4.6 \\
\hline \multicolumn{2}{|l|}{$\begin{array}{l}\chi^{2} \\
P\end{array}$} & \multicolumn{2}{|c|}{4.12} & \multicolumn{2}{|c|}{3.90} & \multicolumn{2}{|c|}{2.42} & \multicolumn{2}{|c|}{3.26} \\
\hline
\end{tabular}

\begin{tabular}{|c|c|c|c|c|c|c|c|c|c|}
\hline \multirow{2}{*}{\multicolumn{2}{|c|}{ (d) Vertical stratum }} & \multirow{2}{*}{\multicolumn{2}{|c|}{$\begin{array}{l}\text { Under- } \\
\text { storey }\end{array}$}} & \multirow{2}{*}{\multicolumn{2}{|c|}{$\begin{array}{c}\text { Lower } \\
\text { midstorey }\end{array}$}} & \multirow{2}{*}{\multicolumn{2}{|c|}{$\begin{array}{c}\text { Upper } \\
\text { midstorey }\end{array}$}} & \multicolumn{2}{|c|}{ Canopy } \\
\hline & & & & & & & & Obs. & Exp. \\
\hline \multirow{4}{*}{$\begin{array}{l}\text { Highest } \\
\text { abun- } \\
\text { dance } \\
\text { in }\end{array}$} & Control & 10 & 7.8 & 2 & 2.7 & 10 & 6.7 & 4 & 8.7 \\
\hline & Liberation thinning & 7 & 6.3 & 2 & 2.2 & 4 & 5.4 & 8 & 7.1 \\
\hline & Swamp Forest & 11 & 9.7 & 5 & 3.3 & 5 & 8.3 & 11 & 10.8 \\
\hline & Plantation & 7 & 11.2 & 3 & 3.8 & 11 & 9.6 & 16 & 12.4 \\
\hline \multicolumn{2}{|l|}{$\begin{array}{l}\chi^{2} \\
P\end{array}$} & \multicolumn{2}{|c|}{2.45} & \multicolumn{2}{|c|}{1.24} & \multicolumn{2}{|c|}{3.50} & \multicolumn{2}{|c|}{3.70} \\
\hline
\end{tabular}




\subsubsection{Disturbance effects on understorey birds}

\subsubsection{Differences in mist-net data between sampling periods}

Standardised mist-netting was done during three separate sampling periods of which two (32 days) were in rainy season conditions and one (16 days) were at the end of the dry season (Tab. 2). To obtain adequate sample sizes for some analyses, it was necessary to pool data from sampling periods. Since a different distribution pattern can occur between seasons, in the following, community level differences between sampling periods are discussed.

\section{Individual numbers}

The median of individuals captured per sample (102m net line, open for 10 daylight hrs) did not differ significantly between the seasons (Friedman test, $\chi^{2}=1.63$, D.F. $=2, p=0.44$ ), neither for the control (Friedman test, $\chi^{2}=4.19$, D.F. $=2, p=0.12$ ) nor for the disturbed compartment (Friedman test, $\chi^{2}=0.06$, D.F. $=2, p=0.97$ ). The average number of individuals per sample in control during February-March 1996 was $c .3 .5$ individuals lower than during the wet season 1997, but this difference was not significant (Wilcoxon test, $Z=-1.61$, two-tailed $p=0.11$ ) (Tab. $15)$.

Tab. 15: Total bird individuals (recaptures excluded) and medians of samples ( $102 \mathrm{~m}$ net line, 10 daylight hrs) in a control, a disturbed compartment and of both combined, by sampling period. $n=$ number of samples obtained in each sampling period.

\begin{tabular}{lcccc}
\hline Sampling period & Total Individuals & \multicolumn{3}{c}{ Median and range } \\
\cline { 3 - 5 } & & $\begin{array}{c}\text { Control } \\
(\mathrm{n}=8)\end{array}$ & $\begin{array}{c}\text { Disturbed } \\
(\mathrm{n}=8)\end{array}$ & $\begin{array}{c}\text { Combined } \\
(\mathrm{n}=16)\end{array}$ \\
\hline Dry season 1996 & 255 & $18(14-23)$ & $22.5(17-31)$ & $20.5(14-31)$ \\
Wet season 1996 & 297 & $21.5(17-32)$ & $22.5(11-30)$ & $22.5(11-32)$ \\
Wet season 1997 & 331 & $24(16-37)$ & $24(18-40)$ & $24.0(16-40)$ \\
\hline
\end{tabular}

The higher absolute numbers of individuals captured during the wet seasons 1996 and 1997 in comparison to the dry season 1996 are mainly caused by two common species. These are Yellow-whiskered Greenbul Andropadus latirostris (increase from 27 to 59 individuals), and Green Hylia Hylia prasina (from sixteen to 25 individuals). The White-throated Greenbul Phyllastrephus albigularis increased from thirteen individuals (dry season 1996) to 28 individuals (wet season 1996), but decreased again to 19 individuals (wet season 1997). Numbers of several other species increased as well: e.g. in the Collared Sunbird Anthreptes collaris from three individuals in both dry and wet season 1996 to sixteen in the wet season 1997, or in the Bluebill Spermophaga haematina from two individuals in the dry season 1996 to eight (wet season 1996) and six (wet season 1997). In contrary to this overall pattern (higher numbers in the last two seasons), there was a slight decrease in numbers for the Olive Sunbird Nectarinia olivacea in 1996 from the dry to the wet season from 49 to 37, but numbers increased again to 46 in the wet season 1997. In addition, Grey-headed Bristlebill Bleda canicapilla individuals decreased from 35 and 33 (dry and wet season 1996) to 23 in the wet season 1997.

However, all these differences were not very pronounced and after excluding the two species Andropadus latirostris and Green Hylia Hylia prasina from the sample, differences in overall 
numbers of individuals between the dry season and the two wet seasons were no longer significant $\left(\chi^{2}=1.42\right.$, D.F. $=1, \mathrm{p}=0.23$ or $\chi^{2}=1.63$, D.F. $=1, \mathrm{p}=0.20$, respectively).

\section{Diversity and abundance-rank patterns}

Species-abundance patterns from both control and disturbed compartment and from all sampling periods did not differ from a (truncated) log-normal ( $\chi^{2}$ Goodness of fit tests, all $\mathrm{p}>$ 0.45 ) nor from a log-series distribution ( $\chi^{2}$ Goodness of fit tests, all $p>0.10$, Fig. 21). The two most abundant species Yellow-whiskered Greenbul Andropadus latirostris and the Olive Sunbird Nectarinia olivacea were captured in more than 35 individuals (37 to 59) in each sampling period except for the period February-March 1996, when only 27 Andropadus latirostris - individuals were captured and Grey-headed Bristlebill Bleda canicapilla (35 individuals) was ranked as second most abundant species. In each season, seven species were represented in at least ten individuals. The number of „rare“ species (less than five individuals) was highest in the dry season 1996 (25 species), but still high (18 and 21) during both wet season sampling periods. Diversity parameters differed slightly between seasons (Tab. 16). The number of species observed after 16 samples was highest in the wet season 1996 (40 species), intermediate in the wet season 1997 (38 species) and lowest in the dry season 1996 (36 species). Shannon, Simpson and Fisher's alpha diversity indices were lower in the dry season compared to both wet season sampling periods, but differences were small. The expected number of species cumulatively captured at $\mathrm{n}$ individuals was higher for one species in the wet season 1996 than in dry season 1996 or wet season 1997. (Tab. 16, Fig. 22). The estimator of total species richness (ACE) was highest in the wet season 1996 (Tab. 16). In that period, the local species pool was estimated at 49 species, while in the wet season 1997 this value was 48 and in the dry season 45 . However, all these differences in species richness were not caused by the presence or absence of dominant species. None of the species caught in considerable numbers in one season was found to be absent in the others.

Tab. 16: Number of species, species diversity indices and richness estimators of the mist-net bird community from different sampling periods (standard deviations in brackets). *Values computed with the help of EstimaeS (Colwell 1997), accumulation level $n=16$ samples per period. ** Values computed using RAREFACT (Krebs 1989). E[n] = expected number of species at $\mathbf{n}$ individuals.

\begin{tabular}{lccc}
\hline & \multicolumn{3}{c}{ Sampling period } \\
\cline { 2 - 4 } & $\begin{array}{c}\text { Feb-Mar 1996 } \\
\text { (dry season) }\end{array}$ & $\begin{array}{c}\text { Sep-Oct 1996 } \\
\text { (wet season) }\end{array}$ & $\begin{array}{c}\text { Jul-Aug 1997 } \\
\text { (wet season) }\end{array}$ \\
\hline Number of species & 36 & 40 & 38 \\
Diversity (Alpha)* $_{\text {Diversity (Shannon)* }}$ & $10.0( \pm 0.97)$ & $11.34( \pm 1.3)$ & $11.1( \pm 1.1)$ \\
Diversity (Simpson 1/D)* $_{\text {Local species pool (ACE)* }}$ & 2.75 & 2.88 & 2.94 \\
E[230] & 9.97 & 12.45 & 13.06 \\
E[240] $* *$ & 43.1 & 49.2 & 47.5 \\
& $35.8( \pm 1.0)$ & $37.2( \pm 1.7)$ & $34.2( \pm 1.6)$ \\
\hline
\end{tabular}

\section{Species composition}

A comparison of the community composition indicates an overall high similarity between seasons (Tab. 17). The two wet seasons 1996 and 1997 were very similar in terms of species composition (Morisita Horn=0.94, 41 species shared), but the similarity of the dry season 1996 
to the wet season 1996 (Morisita Horn=0.92) and to the wet season 1997 (Morisita Horn=0.89) was also high. This, and the high number of 37 shared species indicated only slight turnover in the composition of the community between the sampling periods.

Tab. 17: Observed number of species shared and Morisita Horn sample similarity index for mist-net data from different sampling periods (after Colwell 1997).

\begin{tabular}{|l|l|l|l|l|}
\hline Morisita Horn & Shared species & Dry 1996 & Wet 1996 & Wet 1997 \\
\hline Dry 1996 & & 37 & 37 \\
\hline Wet 1996 & 0.92 & & 41 \\
\hline Wet 1997 & 0.89 & 0.94 & \\
\hline
\end{tabular}

The computation of Morisita sample similarity indices for the control and the disturbed compartment separately, indicated that the bird communities in control were slightly more homogenous between the seasons than those from the disturbed compartment (Tab. 18). However, the differences were not pronounced and all values ranged between 0.83 and 0.95 . The actual similarity in species composition between the seasons is expected to be even higher than the calculated indices suggest, as neither of the different seasons' cumulative species curves did reach complete saturation (Fig. 22)

Tab. 18: Morisita Horn sample similarity index for mist-net data from different sampling periods, given for the bird communities in the control and the disturbed compartment of the study plot (after Colwell 1997).

\begin{tabular}{|l|l|l|l|l|}
\hline Control & Disturbed & Dry 1996 & Wet 1996 & Wet 1997 \\
\hline Dry 1996 & & 0.92 & 0.83 \\
\hline Wet 1996 & 0.88 & & 0.86 \\
\hline Wet 1997 & 0.90 & 0.95 & \\
\hline
\end{tabular}

\section{Habitat preference patterns on species level}

Because of low numbers of individuals, seasonal differences in habitat selection of single species can hardly be assessed. However, for a small set of species, it was possible to calculate habitat preference patterns. In each season, at least ten species were captured in six or more individuals, which is the minimum for the Fisher's exact test.

There was no indication for marked habitat shifts between the sampling periods. In all seasons, significantly more Little Greenbul Andropadus virens individuals were captured in mist-nets installed in the disturbed than in the control compartment (Fisher's exact test, all $\mathrm{p}<0.05$ ). Another species with higher individual numbers in the disturbed mist-nets was the Collared Sunbird Anthreptes collaris. However, significant differences (Fisher's exact test, $\mathrm{p}=0.008$ ) were only found in the wet season 1997 when sixteen individuals were captured, the species was too rare in both previous sampling periods (three individuals) to carry out statistical tests. Similarly, the Green Hylia Hylia prasina was significantly more abundant in the disturbed compartment during the wet season $1996\left(\chi^{2}=4.26\right.$, D.F. $\left.=1, \mathrm{p}=0.039\right)$, but no significant differences appeared during the other sampling periods. 
Species with a significantly lower number of individuals in the disturbed compartment were White-throated Greenbul Phyllastrephus albigularis and the Grey-headed Bristlebill Bleda canicapilla. Differences were visible in all seasons, but significant on the 5\% level only in the wet season 1996 for Phyllastrephus $\left(\chi^{2}=9,14\right.$, D.F. $\left.=1, p=0.003\right)$ and in the wet season 1997 for Bleda $\left(\chi^{2}=5.26\right.$, D.F. $\left.=1, \mathrm{p}=0.02\right)$.

There was no indication for major habitat shifts between sampling periods for any other species. 

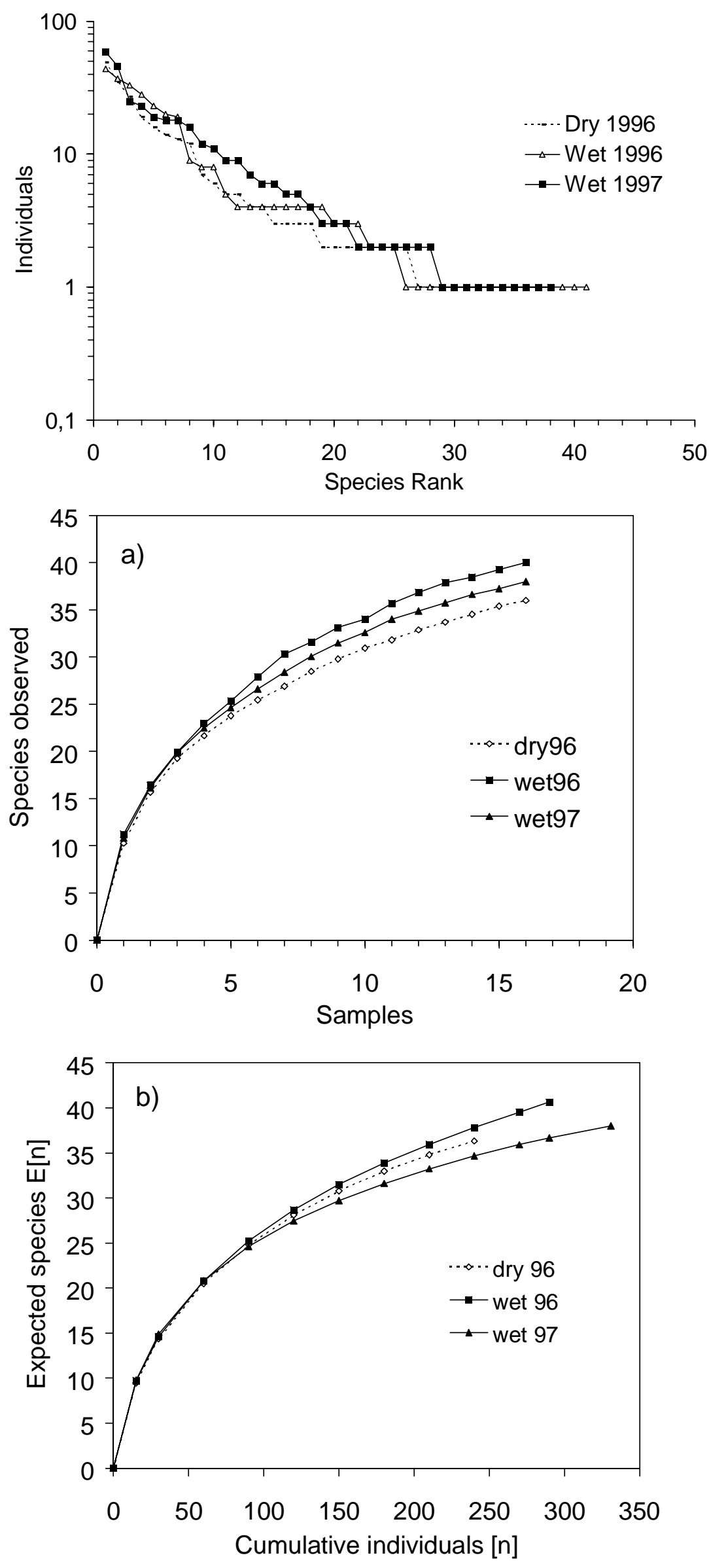

Fig. 21: Rankabundance distribution of bird species captured in mist-nets during different seasons. The most abundant species are Greenbuls (Andropadus latirostris, Phyllastrephus albigularis, Bleda canicapilla), the sunbird Nectarinia olivacea and the warbler Hylia prasina.

Fig. 22: Cumulative species observed per sample (a, after Colwell 1997) and rarefaction curves $(b$, program Rarefact 3.0, Krebs 1989, Achtziger et al. 1992) of bird communities from undergrowth mist-net samples from different seasons (dry season 1996, wet season 1996 , wet season 1997). $E[n]$ $=$ expected number of species at $\mathbf{n}$ individuals cumulatively captured (only first captures are included). 


\subsubsection{Differences between compartments}

\section{Individual numbers}

In total, standardised mist-netting (48 samples) produced 1132 captures from 707 individuals in 49 species at sixteen mist-net sites over three sampling periods. The total number of captures did not differ significantly between the disturbed and the control mist-nets (ChiSquare test, $\chi^{2}{ }_{1 \mathrm{df}}=0.43, \mathrm{p}=0.51$ ), but the number of individuals captured (excluding recaptures) was significantly higher in disturbed (384) than control (325) (Chi-Square test, $\left.\chi^{2}{ }_{1 \mathrm{df}}=5.26, \mathrm{p}=0.022\right)($ Tab. 19).

\section{Species richness, $\alpha$-diversity and evenness}

In both compartments combined, a total of 49 species were captured in mist-nets. In each compartment, a total of 40 species was recorded over the sampling periods. The average number of species captured per sample was significantly lower in control than disturbed (Mann-Whitney U test, $\mathrm{Z}=-2.17, \mathrm{p}=0.030$ ). Similarly, for separate sampling periods, species richness, diversity indices and the estimated size of the local species pool (ACE, Chao1) were higher in the disturbed than in the control compartment (Tab. 19). However, standardising species accumulation in both plots for individual numbers (Achtziger et al. 1992) and samples (rarefaction after Shinozaki 1969) shows that although an initial stronger increase in species accumulation in the disturbed compartment occurred, a slightly higher number of species are to be expected in the control than in the disturbed compartment (Fig. 23, Fig. 24), indicating somewhat more heterogeneous samples in the control compartment.

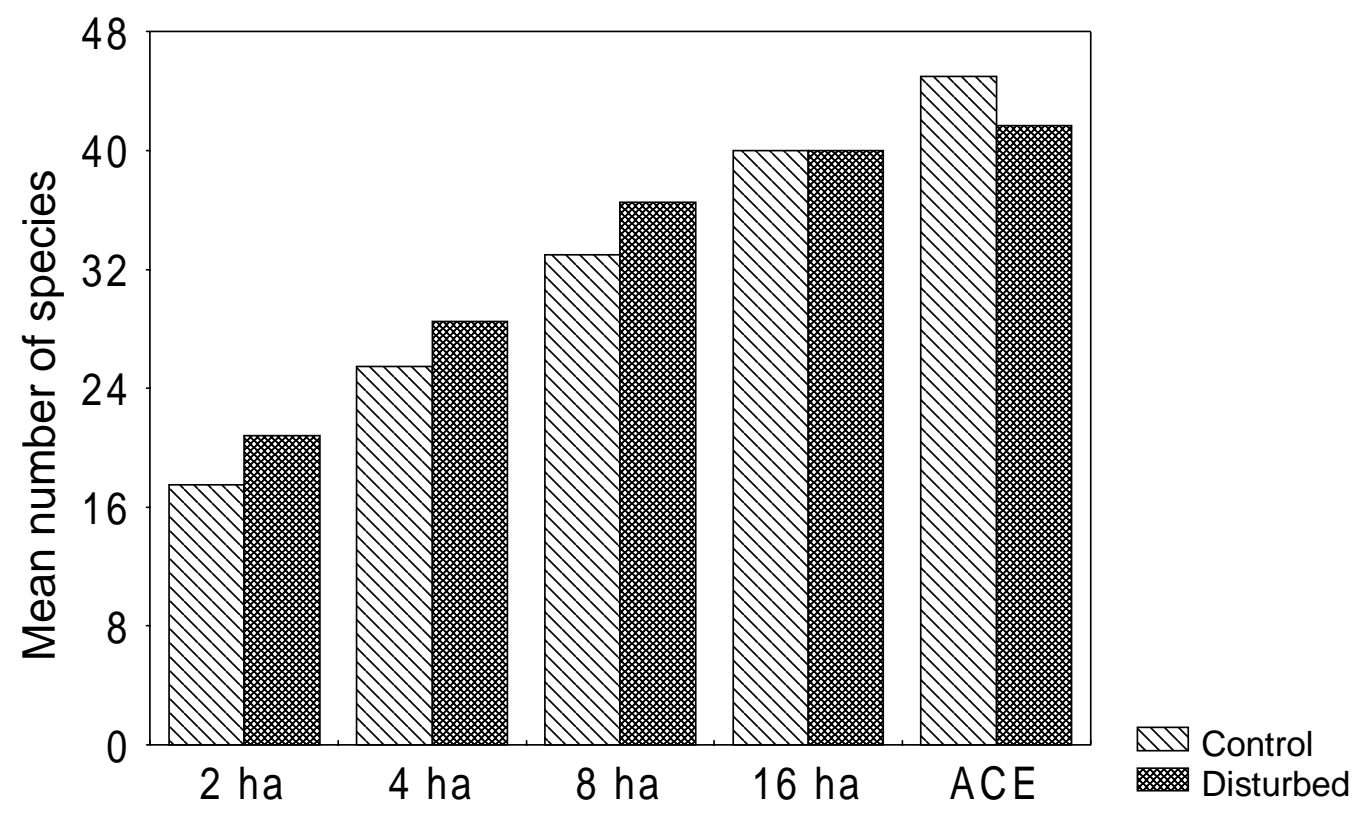

Fig. 23: Mean number of bird species recorded and estimated size of species pool (ACE, see Colwell 1997) in mist-nets successively covering larger (nested) areas of a control and a disturbed compartment of the Bossematié Forest, south-east Côte d'Ivoire. The determination of the sampled area is based on the assumption that one $102 \mathrm{~m}$ mist-net line installed sufficiently often and long enough covers roughly 2 ha. 
Tab. 19: Numbers of individuals (I), numbers of species (S), diversity (Shannon $\mathbf{H}_{S}$, Fisher's alpha, Simpson after Magurran 1988) and richness estimators (ACE, Chao1, see Colwell 1997) of samples of understorey birds mist-netted in two compartments of the Bossematié Forest, eastern Côte d'Ivoire. Results of each column based on the pooled analysis of eight $102 \mathrm{~m}$ mist-net lines covering an appr. area of 16 ha.

\begin{tabular}{|c|c|c|c|c|c|c|}
\hline & \multicolumn{6}{|c|}{ Compartment } \\
\hline & \multicolumn{3}{|c|}{ Control } & \multicolumn{3}{|c|}{ Disturbed } \\
\hline & dry 96 & wet 96 & wet 97 & dry 96 & wet 96 & wet 97 \\
\hline Individuals (I) & 118 & 153 & 165 & 141 & 145 & 173 \\
\hline Species (S) & 22 & 25 & 26 & 26 & 32 & 32 \\
\hline Singletons (\% of S) & $7(32)$ & $7(28)$ & $8(31)$ & $7(27)$ & $15(47)$ & $11(34)$ \\
\hline Diversity $\left(\mathrm{H}_{\mathrm{S}}\right)$ & 2.54 & 2.62 & 2.62 & 2.76 & 2.86 & 2.86 \\
\hline Diversity (alpha) & $8.0( \pm 1.2)$ & $8.5( \pm 1.1)$ & $8.7( \pm 1.1)$ & $9.4( \pm 1.3)$ & $12.7( \pm 1.7)$ & $11.6( \pm 1.4)$ \\
\hline Diversity (Simp. 1/D) & 9.4 & 10.4 & 10.2 & 12.4 & 13.2 & 11.6 \\
\hline Evenness $\left(\mathrm{H}_{\mathrm{S}} / \ln \mathrm{S}\right)$ & 0.82 & 0.81 & 0.80 & 0.85 & 0.83 & 0.83 \\
\hline Richness est. (ACE) & 29.0 & 29.7 & 34.4 & 32.0 & 56.3 & 42.7 \\
\hline Richness est. (Chao1) & $28.1( \pm 6.1)$ & $31.1( \pm 6.1)$ & $31.3( \pm 4.9)$ & $32.1( \pm 6.1)$ & $54.5( \pm 16.1)$ & $44.4( \pm 9.7)$ \\
\hline
\end{tabular}




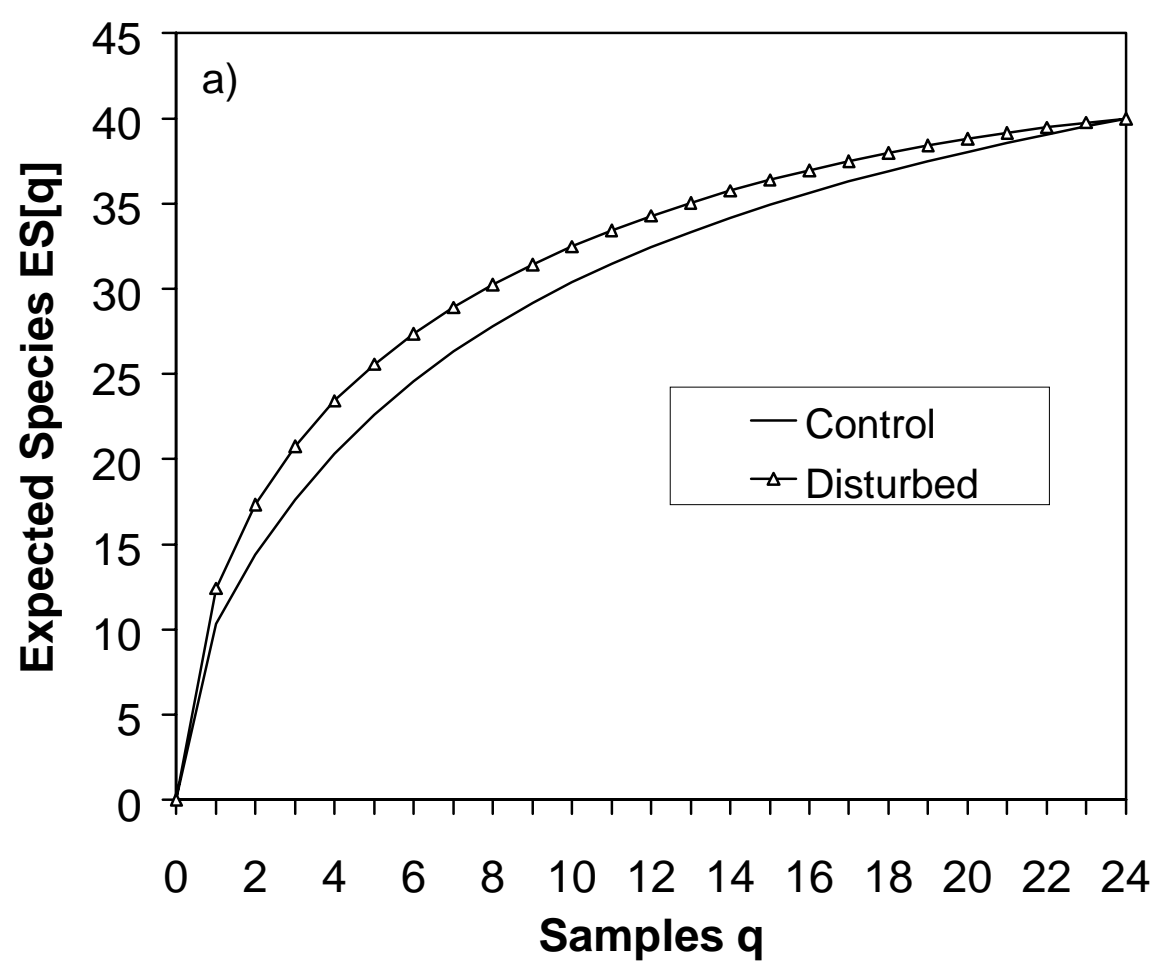

Fig. 24: Shinozaki curves (a) and rarefaction curves (b) for bird communities captured in mist-nets of a control compartment and a disturbed compartment in the Bossematié Forest, south-east Côte d'Ivoire. The curves were calculated for all individuals present in three mist-net periods.

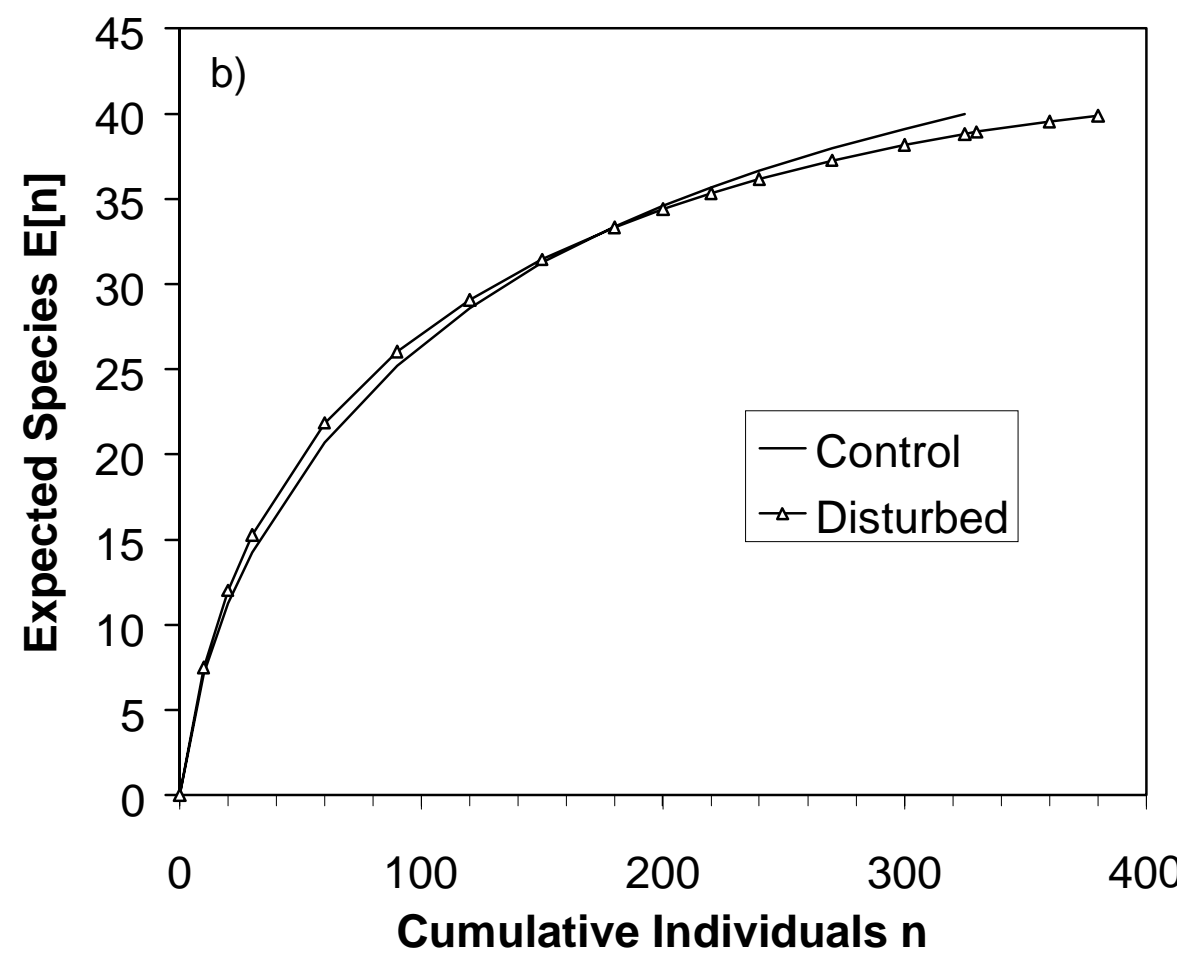

$\beta$-Diversity

Of the 49 species mist-netted, 31 were actually present in both the control and the disturbed compartment. The true number of species shared is estimated at $34 \mathrm{spp}$. (Colwell 1997). The corresponding Morisita Horn sample similarity index amounts to 0.80 . 


\section{Abundance pattern}

The species-abundance patterns of the bird communities assessed by mist-net sampling are shown in Fig. 25. The patterns as such do not differ much between compartments. Both communities contained a set of six to seven common species represented by 5 to $23 \%$ of the total captures. The disturbed compartment had a somewhat larger amount of species with intermediate abundance: eight species were represented by 2 to $5 \%$ of the individuals total, while in this class only four species were found in the control compartment. Consequently, there were some some more (31) rare species (less than $2 \%$ of the total individuals) in control, whereas in the disturbed area this group only contained 26 species.

All abundance patterns fitted both a (truncated) log-normal ( $\chi^{2}$ Goodness of fit tests, $\mathrm{p}>0.1$ ) and a log-series distribution ( $\chi^{2}$ Goodness of fit tests, all $\mathrm{p}>0.45$ ).

Among the most common species, Olive Sunbird Nectarinia olivacea and the Yellowwhiskered Greenbul Andropadus latirostris were often captured in both compartments (more than $10 \%$ of individuals), whereas the Little Greenbul Andropadus virens was only common in the disturbed compartment (9-14 \%) and the Grey-headed Bristlebill Bleda canicapilla only in the control compartment (10-19\%). 


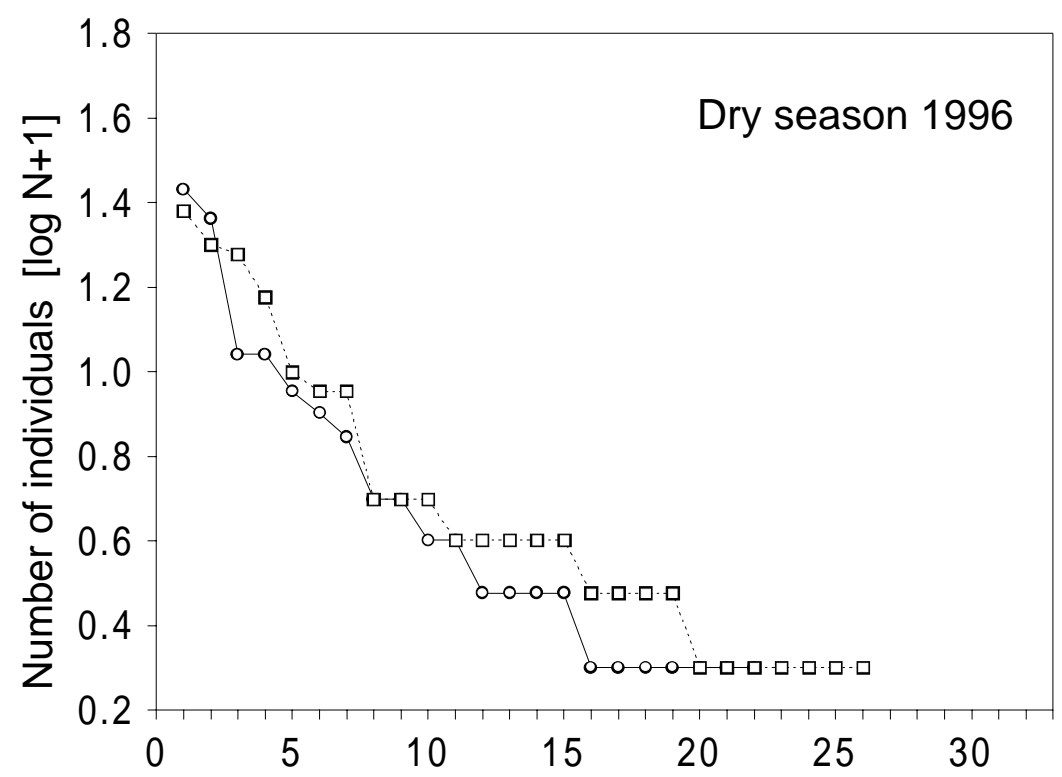

Fig. 25: Rank-abundance plots of understorey bird communities in two different vegetation types of a heavily degraded rainforest in south-east Côte d'Ivoire, a less disturbed control compartment [solid line; dots] and a disturbed compartment [hatched line; squares].
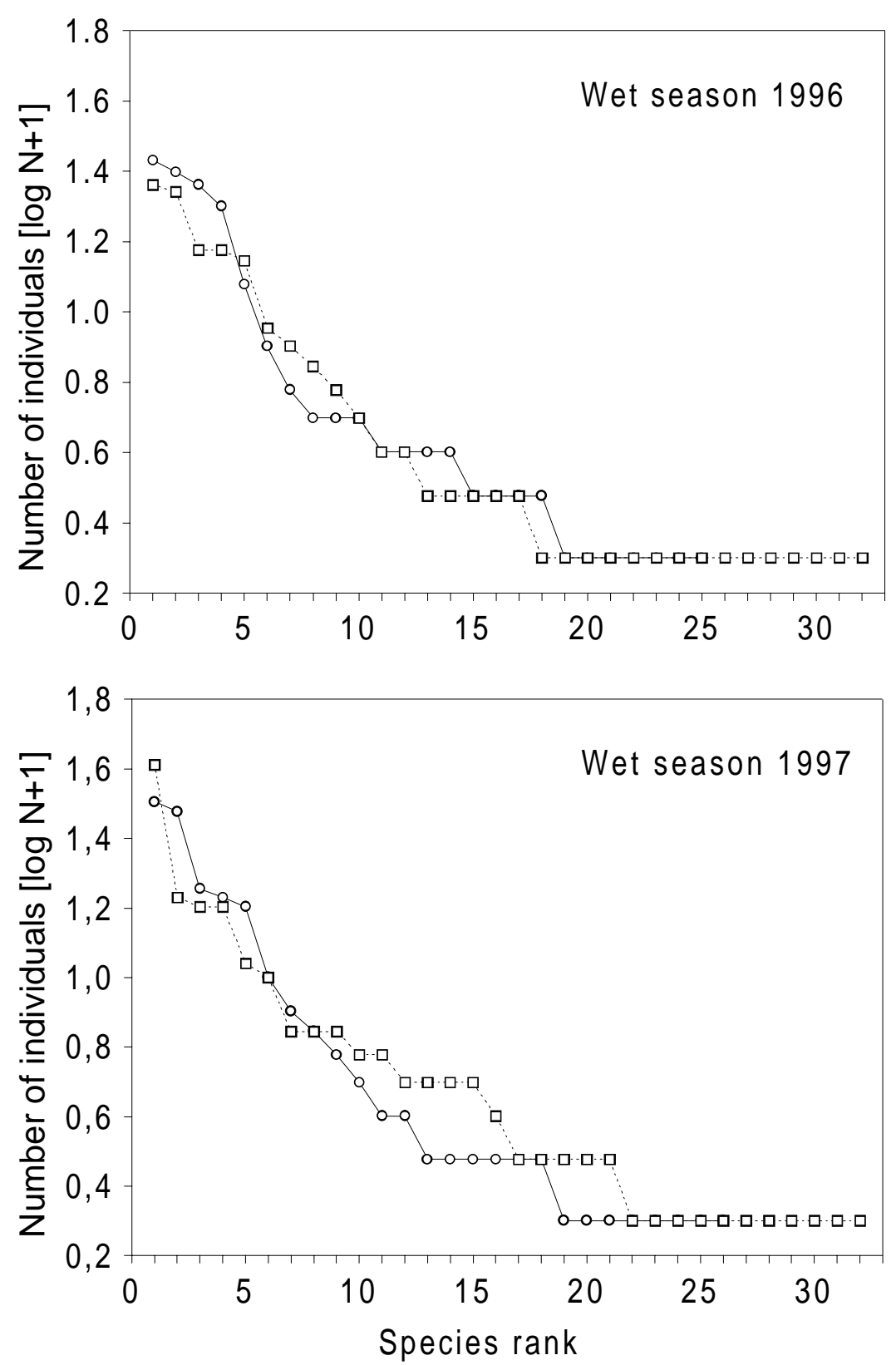


\section{Family level}

Mist-netting on the study plot produced captures of 741 individual birds ( $q=50$ samples, only first captures) of 49 species from 21 families. The most species-rich family were the bulbuls Pycnonotidae with nine species. Other species-rich families were sunbirds Nectariniidae (five species), warblers Sylviidae (five species), estrildid finches Estrildidae (four species), illadopsises Timaliidae (four species), and thrushes Turdidae (four species). Monarchid flycatchers Monarchidae, pigeons Columbidae and francolins Phasianidae were all represented by two species. All other families were represented by one species each (Fig. 26).

A comparison of the number of individuals shows that the most abundant bird families were again Pycnonotidae (305), Nectariniidae (146), Sylviidae (87), Turdidae (47), Timaliidae (37), Monarchidae (35), and Estrildidae (26). The fifteen other bird families were only represented by less than ten individuals each (Fig. 26).

Fig. 27a compares the percentages of species for the six most abundant and species-rich families captured in the two compartments. There were no major differences in the number of species present in each bird family. A slight trend can be stated for the Sylviidae, captured with five species $(18.5 \%)$ in the disturbed, whereas only three $(11.5 \%)$ were present in the control compartment.

An analogous comparison for the precentages of individuals is given in Fig. 27b for the eight most abundant families. There was an overall comparable pattern in both compartments. However, in some families trends were visible. The proportion of Nectariniidae was higher in control $(24.0 \%)$ than in disturbed $(16.9 \%)$. In contrast, the Sylviidae's percentages were higher in disturbed $(12.7 \%)$ compared to control $(9.2 \%)$. The Estrildidae percentages were lower in the control $(2.0 \%)$ than in the disturbed compartment $(5.0 \%)$. No clear trends were found for the other families.

The numbers of captures as well as the numbers of individuals were significantly different between compartments in two families. Sylviidae (five species in total) were significantly more abundant in disturbed than control (Chi-Square tests, $\chi^{2}{ }_{1 \mathrm{df}}=12.17, \mathrm{p}<0.001$ for captures; $\chi^{2} 1 \mathrm{df}=4.38, \mathrm{p}=0.036$ for individuals). The abundance of Estrildidae (four species) was also higher in control, visible in the number of captures (Chi-Square test, $\chi^{2}{ }_{1 \mathrm{df}}=10.8, \mathrm{p}=0.001$ ) and individuals (Chi-Square test, $\chi^{2}{ }_{1 \mathrm{df}}=6.00, \mathrm{p}=0.014$ ). All other families present in considerable numbers (Pycnonotidae, Nectariniidae, Turdidae, Timaliidae and Monarchidae) were equally abundant in both compartments. However, there was a slight proportional difference in numbers of captures and individuals of Pycnonotidae between the compartments that was possibly not caused by sampling error. Whereas over the sampling periods more individuals were captured in the disturbed compartment, more captures were obtained in the control compartment (see also chapter 6.5). This trend was, however, only nearly significant (2 x 2 table Chi-sq. test, $\mathrm{p}=0.094$ ). 


\section{a) Species}

\section{S}

others (12 spp.)

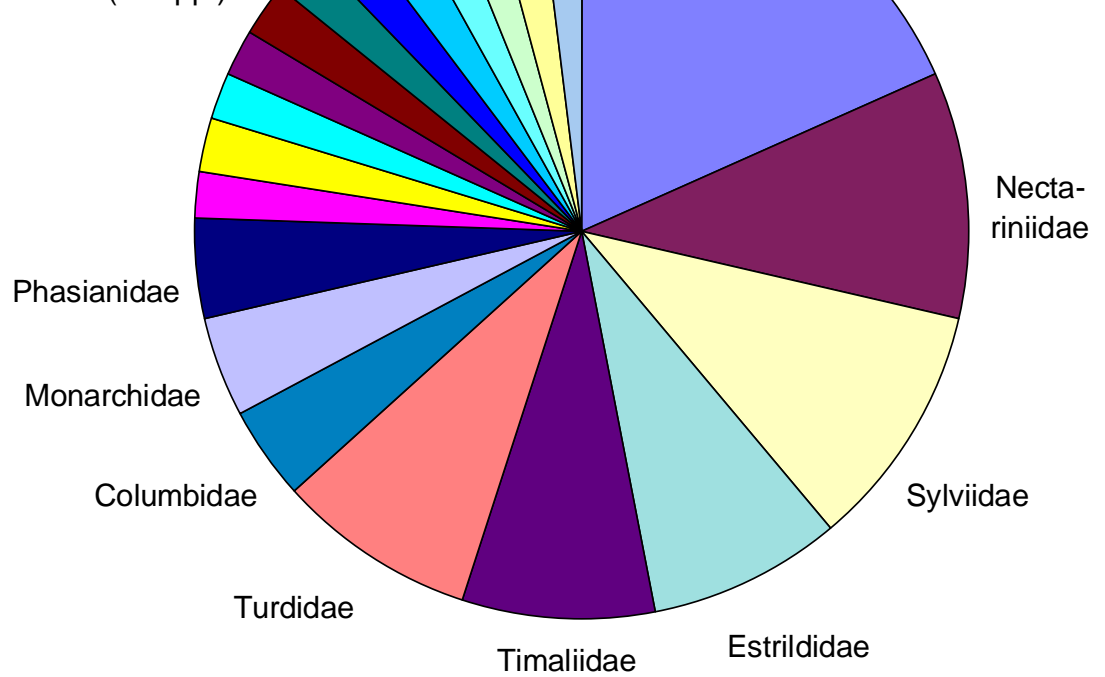

b) Individuals

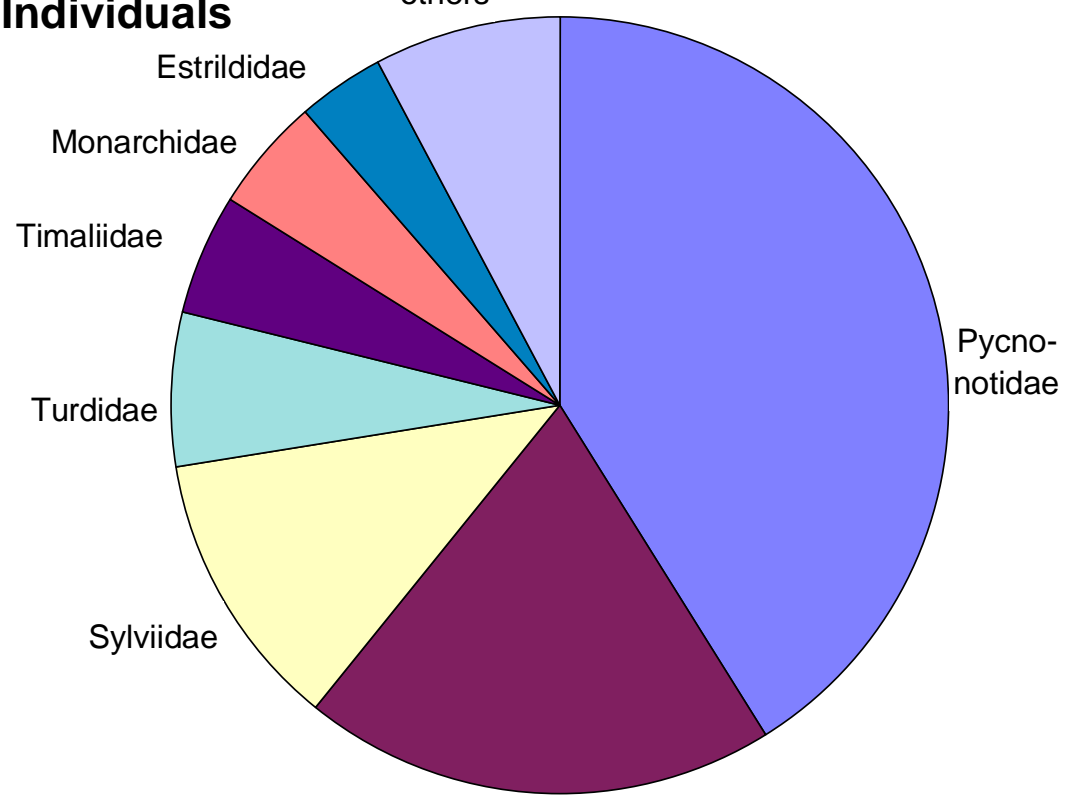

Pycnonotidae

Necta-

iiidae

ycno-

otidae
Fig. 26: Percentages of (a) bird species $(n=49$, left) and (b) individuals $(n=741$, right) of different families captured in undergrowth mist-nets of the Bossematié Forest, south-east Côte d'Ivoire.

Nectariniidae 


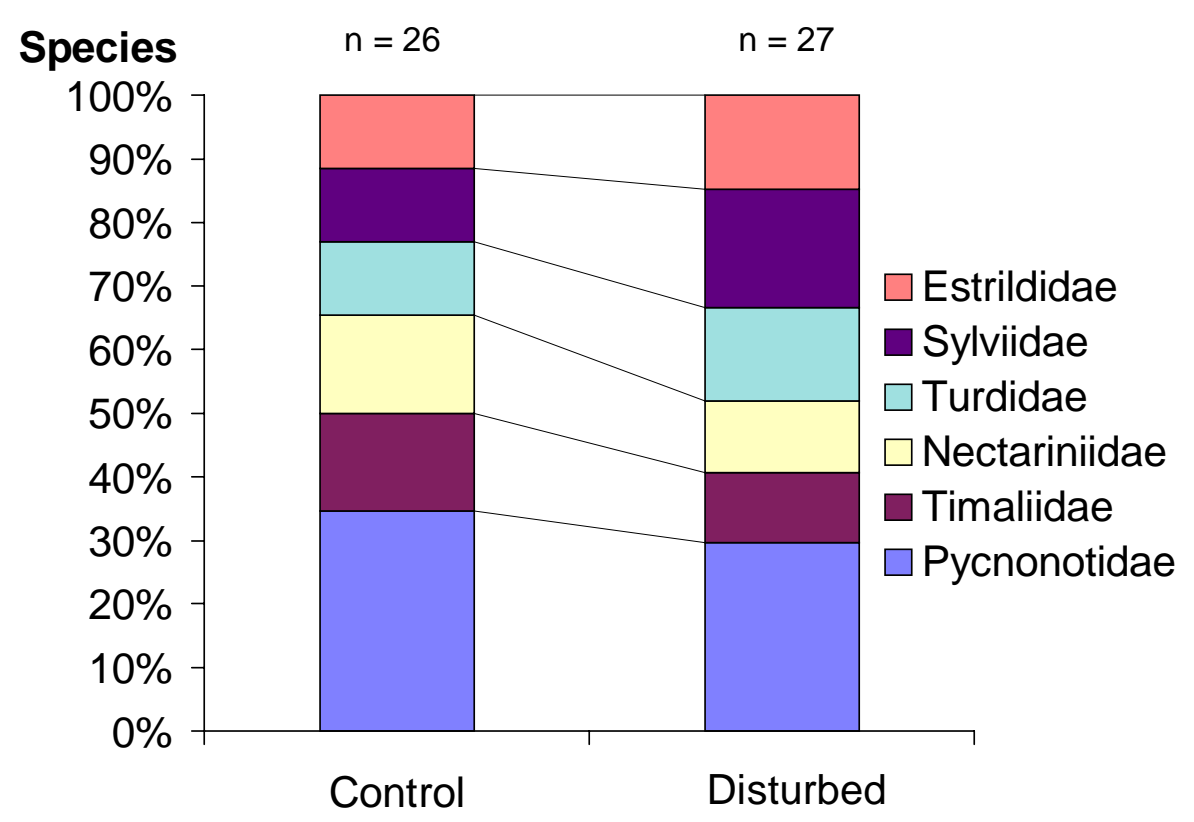

Fig. 27: Percentage of individuals and species of wellrepresented bird families in undergrowth mistnets in two compartments of the Bossematié Forest, south-east Côte d'Ivoire, a control and a disturbed compartment.

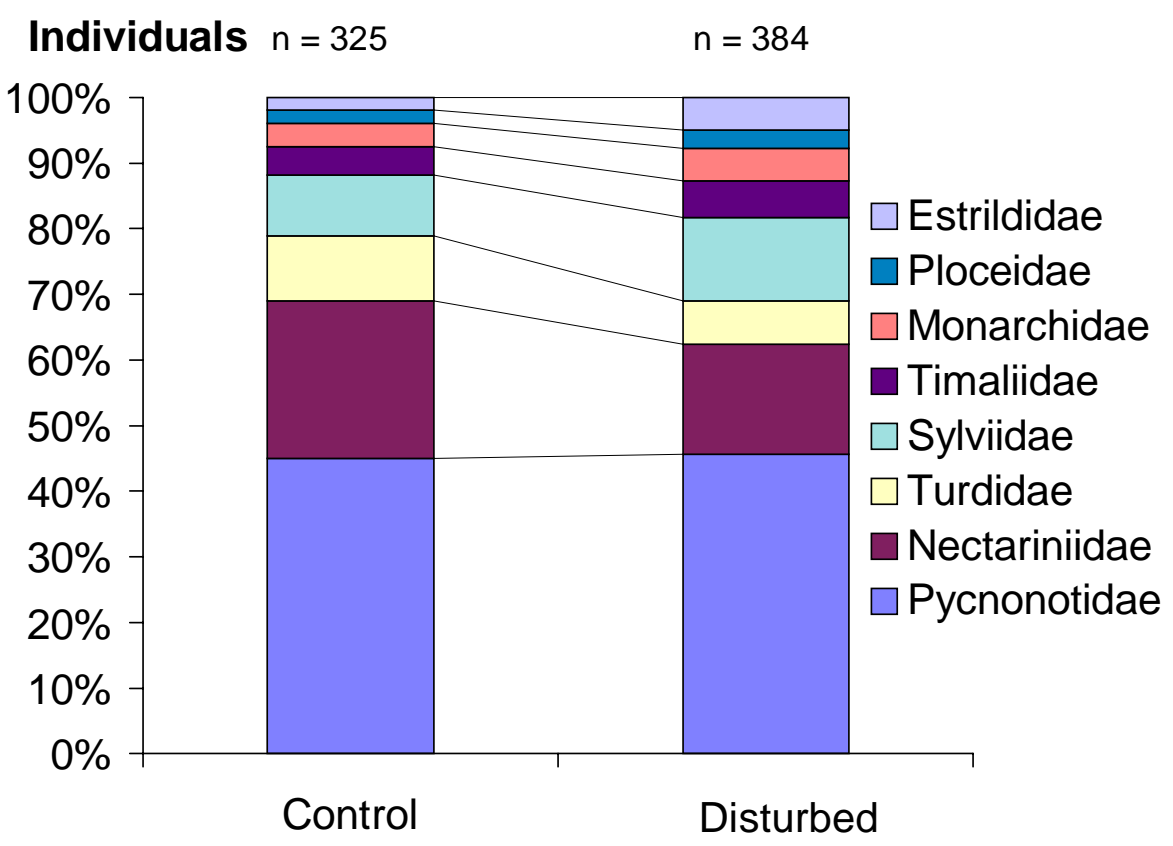

\section{Species level}

Tab. 20 lists the mean numbers of captures of the 49 species mist-netted for each season and each compartment. Thirteen species showed marked differences in capture frequencies between compartments. Of these, eight species were captured more often in the disturbed compartment, whereas five species had a markedly higher abundance in control. 
Tab. 20: Mean numbers of captures of understorey bird species in two compartments in the Bossematié Forest, south-east Côte d'Ivoire, for different sampling periods. Means calculated for one sample (102 m mist-net line, open for 10 daylight hrs) (q = number of samples). Abbr.: Contr. - control compartment, Dist. - disturbed compartment. Species marked with ,a $\mathrm{a}^{\text {" }}$ have significantly different capture rates between compartments, so have those marked with, ,b $\mathrm{b}^{66}$ or , , $\mathrm{c}^{\mathrm{cc}}$ (Mann-Whitney $U$ test, $\mathrm{P}_{\mathrm{a}}<0.05, \mathrm{P}_{\mathrm{b}}<$ $\left.0.01, P_{c}<0.001\right)$.

\begin{tabular}{|c|c|c|c|c|c|c|}
\hline & \multicolumn{2}{|c|}{9 Feb - 21 Mar 1996} & \multicolumn{2}{|c|}{9 Sep - 15 Oct 1996} & \multicolumn{2}{|c|}{21 Jul - 20 Aug 1997} \\
\hline & $\begin{array}{l}\text { Contr. } \\
(\mathrm{q}=8)\end{array}$ & $\begin{array}{l}\text { Dist. } \\
(q=8)\end{array}$ & $\begin{array}{l}\text { Contr. } \\
(q=8)\end{array}$ & $\begin{array}{l}\text { Dist. } \\
(q=8)\end{array}$ & $\begin{array}{l}\text { Contr. } \\
(q=8)\end{array}$ & $\begin{array}{l}\text { Dist. } \\
(\mathrm{q}=8)\end{array}$ \\
\hline \multicolumn{7}{|l|}{ Accipitridae } \\
\hline Accipiter tachiro & 0 & 0.16 & 0 & 0 & 0.27 & 0.11 \\
\hline \multicolumn{7}{|l|}{ Phasianidae } \\
\hline Francolinus ahantensis & 0 & 0 & 0 & 0 & 0 & 0.13 \\
\hline Francolinus lathami & 0 & 0 & 0.14 & 0 & 0.08 & 0 \\
\hline \multicolumn{7}{|l|}{ Columbidae } \\
\hline Turtur brehmeri & 0 & 0.14 & 0.25 & 0 & 0 & 0 \\
\hline Turtur tympanistria & 0 & 0.13 & 0 & 0.12 & 0 & 0 \\
\hline \multicolumn{7}{|l|}{ Alcediniidae } \\
\hline Ceyx lecontei & 0 & 0 & 0.09 & 0 & 0 & 0 \\
\hline \multicolumn{7}{|l|}{ Bucerotidae } \\
\hline Tockus albocristatus & 0.12 & 0 & 0 & 0.13 & 0 & 0.23 \\
\hline \multicolumn{7}{|l|}{ Capitonidae } \\
\hline Trachyphonus purpuratus & 0 & 0 & 0 & 0.26 & 0 & 0 \\
\hline \multicolumn{7}{|l|}{ Indicatoridae } \\
\hline Indicator exilis & 0.13 & 0 & 0 & 0 & 0 & 0 \\
\hline \multicolumn{7}{|l|}{ Picidae } \\
\hline Campethera nivosa & 0.40 & 0 & 0.09 & 0.13 & 0 & 0.11 \\
\hline \multicolumn{7}{|l|}{ Eurylaimidae } \\
\hline Smithornis rufolateralis & 0.12 & 0 & 0 & 0 & 0 & 0 \\
\hline \multicolumn{7}{|l|}{ Pycnonotidae } \\
\hline Andropadus curvirostris & 0.39 & 0.53 & 0 & 0.13 & 0.57 & 1.07 \\
\hline Andropadus latirostris & 1.25 & 3.22 & 3.92 & 3.30 & 4.38 & 5.39 \\
\hline Andropadus virens ${ }^{\mathrm{c}}$ & 0.14 & 3.02 & 0.36 & 3.65 & 0.22 & 2.29 \\
\hline Bleda canicapilla ${ }^{\mathrm{a}}$ & 4.59 & 2.91 & 3.22 & 2.75 & 2.60 & 1.46 \\
\hline Bleda eximia & 0.37 & 0.13 & 0.22 & 0 & 0.13 & 0.12 \\
\hline Bleda syndactyla ${ }^{\mathrm{b}}$ & 1.01 & 0 & 1.45 & 0.38 & 1.26 & 0.19 \\
\hline Criniger barbatus & 0 & 0 & 0 & 0 & 0.29 & 0 \\
\hline Criniger calurus & 0 & 0.26 & 0.31 & 0.13 & 0 & 0 \\
\hline Phyllastrephus albigularis ${ }^{\mathrm{a}}$ & 1.54 & 0.84 & 3.00 & 1.04 & 2.11 & 0.73 \\
\hline \multicolumn{7}{|l|}{ Turdidae } \\
\hline Alethe diademata & 1.41 & 2.54 & 2.47 & 1.30 & 1.32 & 1.82 \\
\hline Neocossyphus finshii & 0 & 0 & 0 & 0.13 & 0 & 0 \\
\hline Neocossyphus poensis & 0.12 & 0 & 0.40 & 0.13 & 0.39 & 0.26 \\
\hline Stiphrornis erythrothorax & 0.62 & 0.13 & 0.58 & 0.00 & 0.16 & 0.10 \\
\hline \multicolumn{7}{|l|}{ Sylviidae } \\
\hline Camaroptera chloronota & 0.26 & 1.30 & 0.27 & 0.25 & 0.51 & 0.51 \\
\hline Camaroptera superciliaris & 0.12 & 0.11 & 0 & 0.26 & 0 & 0.27 \\
\hline Hylia prasina & 1.15 & 2.21 & 0.92 & 2.31 & 1.99 & 1.22 \\
\hline Macrosphenus kempi ${ }^{\mathrm{b}}$ & 0 & 0.58 & 0 & 0.13 & 0 & 0.85 \\
\hline Sylvietta virens & 0 & 0.38 & 0 & 0.13 & 0 & 0.13 \\
\hline \multicolumn{7}{|l|}{ Muscicapidae } \\
\hline Muscicapa epulata & 0 & 0.35 & 0.48 & 0 & 0 & 0.45 \\
\hline
\end{tabular}


(Tab. 20 cont.)

\begin{tabular}{|c|c|c|c|c|c|c|}
\hline & \multicolumn{2}{|c|}{9 Feb - 21 Mar 1996} & \multicolumn{2}{|c|}{9 Sep - 15 Oct 1996} & \multicolumn{2}{|c|}{21 Jul - 20 Aug 1997} \\
\hline & $\begin{array}{l}\text { Contr. } \\
(\mathrm{q}=8)\end{array}$ & $\begin{array}{l}\text { Dist. } \\
(\mathrm{q}=8)\end{array}$ & $\begin{array}{l}\text { Contr. } \\
(\mathrm{q}=8)\end{array}$ & $\begin{array}{l}\text { Dist. } \\
(\mathrm{q}=8)\end{array}$ & $\begin{array}{l}\text { Contr. } \\
(\mathrm{q}=8)\end{array}$ & $\begin{array}{l}\text { Dist. } \\
(\mathrm{q}=8)\end{array}$ \\
\hline \multicolumn{7}{|l|}{ Monarchidae } \\
\hline Terpsiphone rufiventer & 0 & 0.57 & 0.48 & 0.64 & 0.54 & 0.70 \\
\hline Trochocercus nitens & 0.37 & 0 & 0.13 & 0.53 & 0.20 & 0.31 \\
\hline \multicolumn{7}{|l|}{ Platysteiridae } \\
\hline Diaphorophyia castanea & 0.29 & 0 & 0.10 & 0 & 0 & 0 \\
\hline \multicolumn{7}{|l|}{ Timaliidae } \\
\hline Illadopsis cleaveri & 0.36 & 0.55 & 0.10 & 0.26 & 0 & 0.14 \\
\hline Illadopsis fulvescens & 0 & 0 & 0.53 & 0 & 0.43 & 0.75 \\
\hline Illadopsis rufescens & 0 & 0 & 0 & 0 & 0.21 & 0 \\
\hline Illadopsis rufipennis & 0.60 & 1.25 & 0 & 0.67 & 0.22 & 0.14 \\
\hline \multicolumn{7}{|l|}{ Nectariniidae } \\
\hline Anthreptes collaris ${ }^{\mathrm{b}}$ & 0.12 & 0.41 & 0.24 & 0.26 & 0.12 & 2.41 \\
\hline Anthreptes fraseri & 0 & 0 & 0 & 0 & 0.10 & 0 \\
\hline Nectarinia seimundi & 0.12 & 0 & 0 & 0 & 0.10 & 0 \\
\hline Nectarinia chloropygia & 0 & 0 & 0 & 0.27 & 0 & 0 \\
\hline Nectarinia olivacea & 6.61 & 4.79 & 3.95 & 2.71 & 5.32 & 2.50 \\
\hline \multicolumn{7}{|l|}{ Malaconotidae } \\
\hline Nicator chloris & 0 & 0.11 & 0.23 & 0.26 & 0.12 & 0.26 \\
\hline \multicolumn{7}{|l|}{ Dicruridae } \\
\hline Dicrurus adsimilis & 0 & 0 & 0 & 0.13 & 0 & 0.13 \\
\hline \multicolumn{7}{|l|}{ Ploceidae } \\
\hline Malimbus nitens & 0 & 0.25 & 0.44 & 0.66 & 0.32 & 0.52 \\
\hline \multicolumn{7}{|l|}{ Estrildidae } \\
\hline Mandingoa nitidula & 0.26 & 0 & 0 & 0.13 & 0 & 0 \\
\hline Nigrita bicolor $^{\mathrm{a}}$ & 0 & 0.11 & 0 & 0.14 & 0 & 0.28 \\
\hline Nigrita canicapilla & 0 & 0 & 0 & 0.27 & 0.12 & 0.13 \\
\hline Spermophaga haematina & 0 & 0.53 & 0.13 & 0.93 & 0.18 & 0.61 \\
\hline
\end{tabular}

\section{Species with higher capture rates in the disturbed compartment}

Among the eight species with higher capture rates in the disturbed compartment, six small insectivorous species of sunbirds (Anthreptes collaris), warblers (Hylia prasina, Camaroptera superciliaris, Macrosphenus kempi, Sylvietta virens) and estrildids (Nigrita bicolor) were found. One true understorey greenbul, the omnivorous Little Greenbul Andropadus virens and the Bluebill Spermophaga haematina, a large seed-eating understorey estrildid, were also captured more frequently in the disturbed compartment. The differences were significant for Collared Sunbird Anthreptes collaris (Mann-Whitney U-test, $\mathrm{Z}=-2.318, \mathrm{p}=0.010$ ), Kemp's Longbill Macrosphenus kempi (Mann-Whitney U-test, $\mathrm{Z}=-2.896, \mathrm{p}=0.004$ ), Little Greenbul Andropadus virens (Mann-Whitney U-test, $\mathrm{Z}=-3.370, \mathrm{p}<0.001$ ) and the Chestnut-breasted Negrofinch Nigrita bicolor (Mann-Whitney U-test, $Z=-2.208, \mathrm{p}=0.027$ ). Differences were nearly significant for Bluebill Spermophaga haematina (Mann-Whitney U-test, $\mathrm{Z}=-2.631, \mathrm{p}=$ 0.085), Yellow-browed Camaroptera Camaroptera superciliaris (Mann-Whitney U-test, Z = 1.788, $\mathrm{p}=0.074$ ), Green Hylia Hylia prasina (Mann-Whitney U-test, $\mathrm{Z}=-1.680, \mathrm{p}=0.093$ ), and the Green Crombec Sylvietta virens (Mann-Whitney U-test, $\mathrm{Z}=-1.849, \mathrm{p}=-1.849, \mathrm{p}=$ 0.065, all tests two-tailed). Ahanta Francolin Francolinus ahantensis, a highly reproductive phasianid species with a large clutch size, common in farmbush areas around the Forêt Classée, Tambourine Dove Turtur tympanistria, Yellow-billed Barbet Trachyphonus 
purpuratus, and the Drongo Dicrurus adsimilis were only trapped in the disturbed compartment as well. The abundance of these species is certainly associated with forest disturbance, but due to larger homeranges (Ahanta Francolin) and/or preference for higher vegetation strata (e.g. Tambourine Dove, Drongo and Barbet), densities could not be adequately assessed by mist-netting.

\section{Species with higher capture rates in the control compartment}

Five species showed a marked reduction in capture rates in the disturbed compartment: the two large insectivorous Bristlebills Bleda canicapilla and Bleda syndactyla, the large sunbird Nectarinia olivacea, the medium-sized insectivorous Greenbul Phyllastrephus albigularis, and the platysteirid flycatcher Diaphorophyia castanea. Differences were significant for Greyheaded Bristlebill Bleda canicapilla (Mann-Whitney U-test, $Z=-2.75, \mathrm{p}=0.027$ ), Bristlebill Bleda syndactyla (Mann-Whitney U-test, $\mathrm{Z}=-2.750, \mathrm{p}=0.006$ ), White-throated Greenbul Phyllastrephus albigularis (Mann-Whitney U-test, $\mathrm{Z}=-1.997, \mathrm{p}=0.046$ ), Olive Sunbird Nectarinia olivacea (Mann-Whitney U-test, $Z=-2.836, p=0.005$ ) and nearly significant for the Chestnut Wattle-eye Diaphorophyia castanea (Mann-Whitney U-test, $\mathrm{Z}=-1.849, \mathrm{p}=$ 0.065 , all tests two-tailed). In addition, there was a decrease in the average number of captures for several other medium-sized or larger species in the disturbed compartment. This holds true for at least six more real understorey insectivores, namely Forest Robin Stiphrornis erythrothorax, Red-sided Broadbill Smithornis rufolateralis, White-tailed Ant-thrush Neocossyphus poensis, Western Bearded Bulbul Criniger barbatus, the Upper Guinean restricted Rufous-winged Illadopsis Illadopsis rufescens and Latham's Forest Francolin Francolinus lathami, a true rainforest species with a comparatively small clutch size. The Little Green Sunbird Nectarinia seimundi was also found only in the control plot. However, due to the general low abundance in these species and the variation in numbers, no difference is significant.

\section{Species with unaffected capture rates}

The fourteen following species trapped in adequate numbers did not show major differences in capture rates between compartments: Buff-spotted Woodpecker Campethera nivosa, Yellowwhiskered Greenbul Andropadus latirostris, Cameroon Sombre Greenbul Andropadus curvirostris, Red-tailed Greenbul Criniger calurus, the thrush Alethe diademata, the malaconotid West African Nicator Nicator chloris, the warbler Olive-green Camaroptera Camaroptera chloronota, the timaliids Illadopsis cleaveri, I. fulvescens, I. rufipennis, the flycatcher Muscicapa epulata, the monarchids Terpsiphone rufiventer, Trochocercus nitens, and the ploceid weaver Malimbus nitens (Mann-Whitney $\mathrm{U}$ tests, $\mathrm{p}>0.1$ for all species).

\section{Summary capture rates}

Eleven out of the 49 species captured were simply too rare in the samples to get an adequate abundance estimation. Amongst them were five species that are (probably) essentially forest interior understorey species (Bleda eximia, Ceyx lecontei, Indicator exilis, Neocossyphus finshii, Mandingoa nitidula). However, for these five species no additional information could be obtained by spot-mapping either and therefore no habitat preferences could be estimated. Three further species were occasionally captured large species (Tockus albocristatus, Accipiter tachiro, Turtur brehmeri) and three further species essentially occupy - at least in closed forest 
- higher strata and were therefore not adequately captured in mist-nets (Nectarinia chloropygia, Anthreptes fraseri, Nigrita canicapilla). For the last three species, additional information is available from spot-mapping (see appendix D).

Consequently, the number of species for which habitat use patterns could be estimated, is reduced to 38. Twelve of them (32\%) showed higher capture rates in the disturbed compartment. The difference was significant on the $5 \%$ level in four species and at least a trend could be stated for four more species. However, as larger bird species usually have lower densities, the overall probability to obtain adequate abundance estimates (i.e. capture frequencies) is always higher in smaller species. The field design applied in this study allowed the analysis on habitat use for smaller species such as warblers and sunbirds. Almost all of these arboreal foraging insectivorous species showed a significantly higher capture frequency in the disturbed compartment. However, at least in one species, Kemp's Longbill Macrosphenus kempi, this must be caused by a shift in vertical stratification. In the spotmapping census, this species was recorded in even higher numbers in the control area (see appendix D) and belongs to the birds of mid-strata (e.g. in Yapo forest, Ron Demey pers. comm.). This could also be the case for the Chestnut-breasted Negrofinch Nigrita bicolor, for which no adequate spot-mapping data could be obtained due to insufficient knowledge of the species' voice. Two more species with a significantly higher abundance in the disturbed compartment were an omnivorous medium-sized Greenbul (Andropadus virens) and a large seed-eating estrildid (Spermophaga haematina). Including the Ahanta Francolin Francolinus ahantensis, Drongo Dicrurus adsimilis and the Yellow-billed Barbet Trachyphonus purpuratus, a total of twelve species preferred the disturbed compartment.

Twelve other species (32\%) showed preferences for the control compartment. They were mostly medium-sized or large insectivorous species such as pycnonotids from the genera Bleda, Criniger or Phyllastrephus. Five of them were true understorey insectivorous species but as they were present only in very low numbers, the differences could not be proved statistically.

Fourteen species (36\% of the 38) were found without major differences in capture frequencies between compartments.

\section{Habitat preference and geographic range}

The 49 bird species in mist-net samples included two restricted-range species, Green-tailed Bristlebill Bleda eximia, and the Rufous-winged Illadopsis Illadopsis rufescens. Both are confined to Upper Guinean forests (Category A2 species, Endemic Bird Area 085, see Stattersfield et al. 1998). 34 mist-netted species belong to the Guinea-Congo forest biome (Category A3 species, Fishpool in prep.), twelve species are widespread in African forests, and one species, the Drongo Dicrurus adsimilis, is a widespread ubiquitous species occurring as well in savannah as long as sufficiently large trees are available. Defining each species' association with the less disturbed habitat ("control" compartment) as the proportion of captures obtained there, a modest but significant, negative relationship between the extent of the species' geographic range and their habitat preference was found (Gamma rank correlation for multiple ties, $\gamma=-0.409, p=0.007, n=49$ spp., see Fig. 28). Including only species with a minimum of six captures reduces the number of species in the analysis to 27 , but the 
relationship remains significant (Gamma rank correlation for multiple ties, $\gamma=-0.466, \mathrm{p}=$ 0.037).

\section{Habitat preference and body mass}

Body mass is the most frequently used index of body size in ornithological literature. In this study, most mist-netted species with a minimum number of six captures were Passeriformes ranging in mean body weight from $8 \mathrm{~g}$ (Collared Sunbird Anthreptes collaris) to $56 \mathrm{~g}$ (Whitetailed Ant-thrush Neocossyphus poensis). Many species with considerably higher capture rates in the disturbed compartment were small understorey insectivores such as sunbirds or warblers (see above, Tab. 20). In contrast, most species preferring the control compartment were medium to large-sized insectivorous species such as the Bristlebills Bleda spp. or the Whitethroated Greenbul Phyllastrephus albigularis (Tab. 20). Consequently, an interspecific comparison of the 27 passerines with at least six captures, indicated a modest, significantly positive correlation between body size and preference for the control compartment (Spearman $\mathrm{R}=0.507, \mathrm{t}(\mathrm{N}-2)=2.9413, \mathrm{p}=0.007$, see Fig. 29). This pattern was mainly caused by greenbuls Pycnonotidae, an essentially forest group, where the correlation is even strong $(n=9$ spp., Spearman R =0.857, t $[\mathrm{N}-2]=4.403, \mathrm{p}=0.003)$.

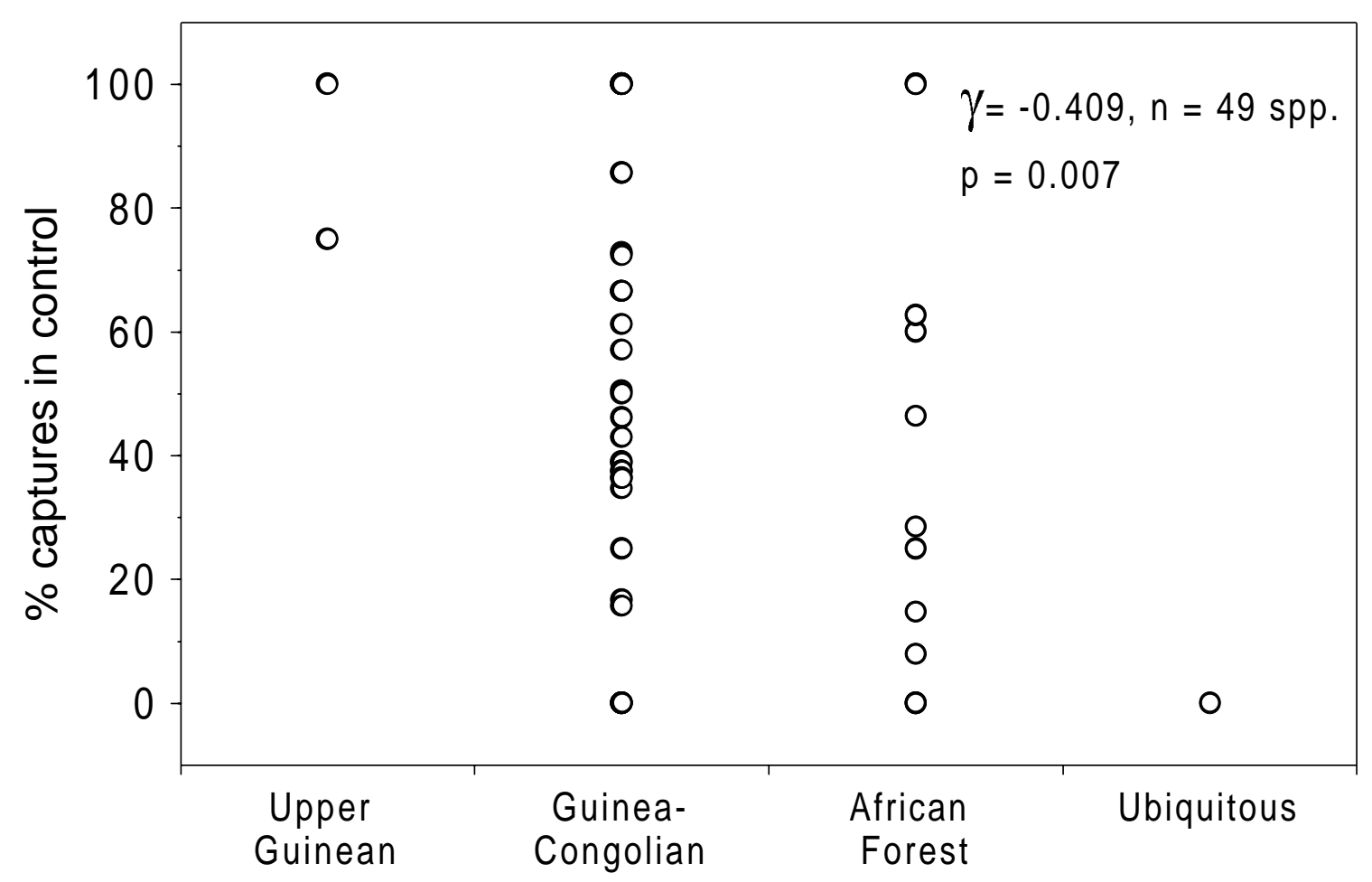

Fig. 28: Relationship between geographic distribution and habitat preference in 49 understorey bird species from mist-net samples in two compartments of the Bossematié Forest, south-east Côte d'Ivoire. The Gamma rank correlation coefficient indicates that the preference for a less disturbed control compartment (\% captures in control) decreases significantly with the size of geographic range. 


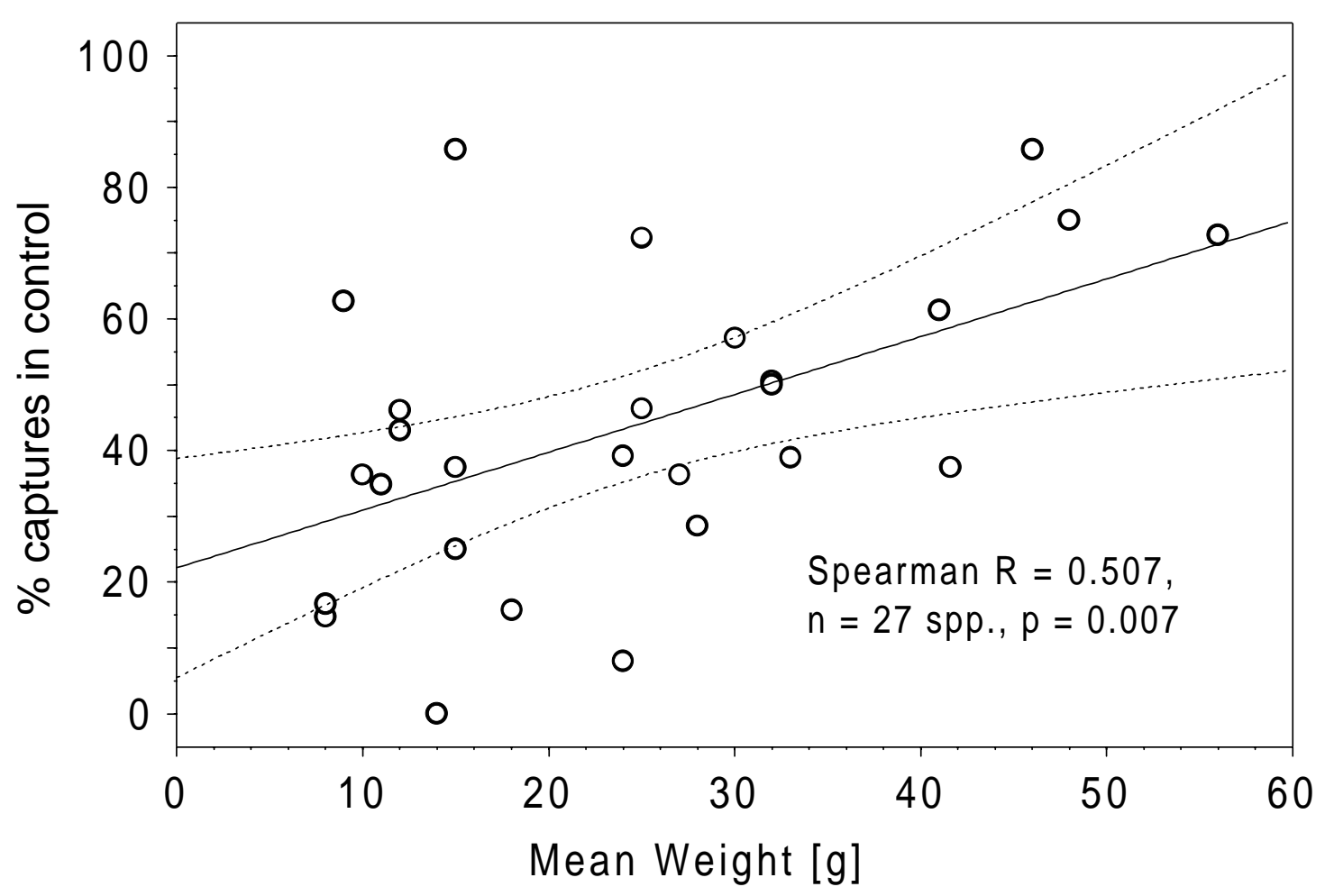

Fig. 29: Relationship between body mass and habitat preference in 27 Passeriformes from understorey mist-net samples in the Bossematié Forest, south-east Côte d'Ivoire. The correlation coefficient indicates a modest positive correlation between body mass and preferential use of a less disturbed control compartment (\% captures in control).

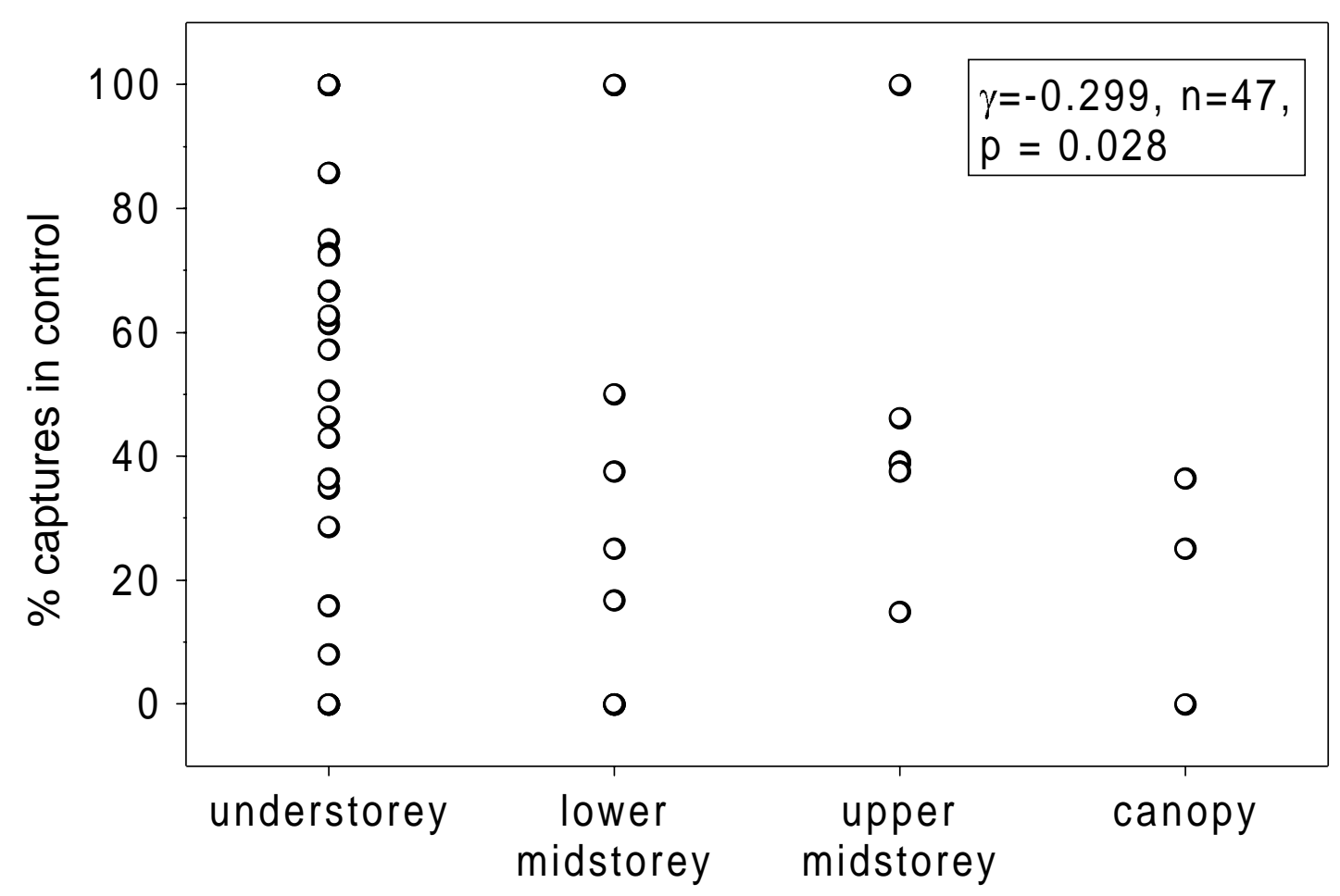

Fig. 30: Relationship between preferred vertical foraging niche and habitat preference of birds captured in understorey mist-nets in the Bossematié Forest, south-east Côte d'Ivoire. The Gamma rank correlation coefficient indicates a weak, but significant negative correlation between the preferential foraging stratum and the proportion of captures obtained in a less disturbed control compartment (\% captures in control). 


\section{Habitat preference and vertical foraging niche}

Of the 49 bird species captured in mist-nets, 28 species are known to occupy the lowermost strata ("understorey") of forests between 0 and $5 \mathrm{~m}$ height (all data compiled from mature forests, see Gatter 1998, Demey \& Fishpool 1994). Ten species are known to have preferential foraging heights between 5 and $10 \mathrm{~m}$ ("lower midstorey"), six species mainly use heights between 10 and $20 \mathrm{~m}$ ("upper midstorey"), and three more are usually found higher up than 20 m ("canopy"). For two species, African Goshawk Accipiter tachiro and the Least Honeyguide Indicator exilis no or contradictory information is available on foraging heights. It has often been stated that bird species of higher vegetational strata follow the contour line of the canopy while foraging. Therefore, they can only be captured in intact forests on ground level in gaps or at edges but never in the shaded understorey (e.g. discussion in Karr 1976). In an interspecific comparison including all species with known preferred vertical foraging stratum, a weak, but significant, negative correlation between average foraging height and relative preference for the less disturbed control compartment was found (Gamma rank correlation for multiple ties, $\gamma=-0.299, \mathrm{p}=0.028$, see Fig. 30). This leads to the conclusion that birds of higher vegetational strata are more easily captured in the disturbed than in the control compartment.

\section{Habitat preference and diet}

Fig. 31 shows the feeding guild composition of the understorey bird community captured in mist-net samples. Most species (33 or 67\%) captured in mist-nets are insectivores. A second and third place in the ranking of feeding guilds in terms of species numbers are nectarivoresinsectivores (10\% of all species), and granivorous species (10\%, constituted of Phasianidae, Columbidae, Estrildidae), followed by omnivores (6\%), frugivores (4\%) and carnivores (2\%).

Most captures were obtained for the 33 insectivorous species (54\%). Despite the comparatively large proportion of nectarivorous species present in the undergrowth of the Bossematié Forest, their capture numbers were outweighed by the largely omnivorous (frugivorous-insectivorous) greenbuls Andropadus latirostris and A. virens (23\%). However, captures of Nectariniidae (Nectarinia olivacea as dominant species) also built a high percentage of the total captures $(20 \%)$. In contrast, captures of granivores, frugivores and carnivores were low $(<3 \%)$.

The proportions of captures from different feeding guilds differed among compartments (Chisq. test, $\left.\chi^{2}=119.6, \mathrm{p}_{5 \mathrm{df}}<0.001\right)$. Captures of nectarivores were higher in the control than in the disturbed compartment (Chi-sq. test, $\chi^{2}=5.08$, $\mathrm{p}_{1 \mathrm{df}}=0.024$ ), but considerably more omnivores (Chi-sq. test, $\chi^{2}=23.52, \mathrm{p}_{1 \mathrm{df}}<0.001$ ) and granivores (Chi-sq. test, $\chi^{2}=6.26, \mathrm{p}_{1 \mathrm{df}}=0.012$ ) were captured in disturbed compared to control. The capture rate of insectivores, however, did not differ significantly between compartments (Chi-sq. test, $\chi^{2}=3.70$, $\mathrm{p}_{1 \mathrm{df}}=.0 .054$ ). 


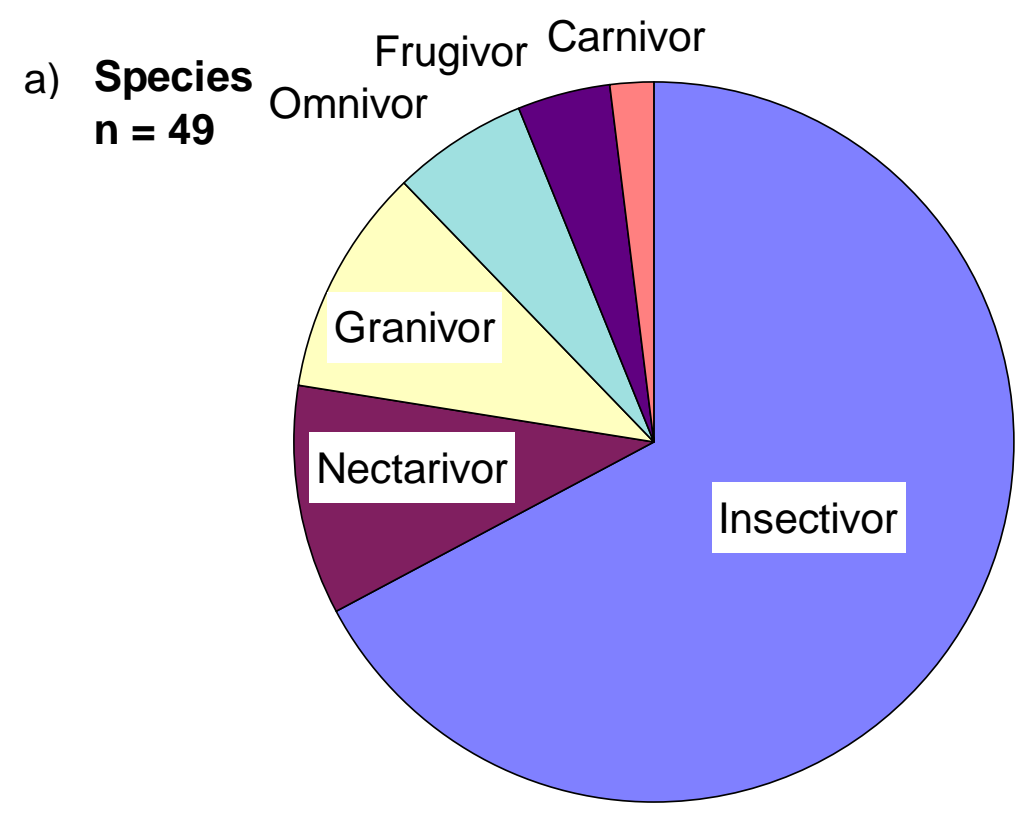

Fig. 31: Feeding guild composition according to numbers of (a) species and (b) captures of the understorey bird community in the Bossematié Forest, southeast Côte d'Ivoire.

b) Captures

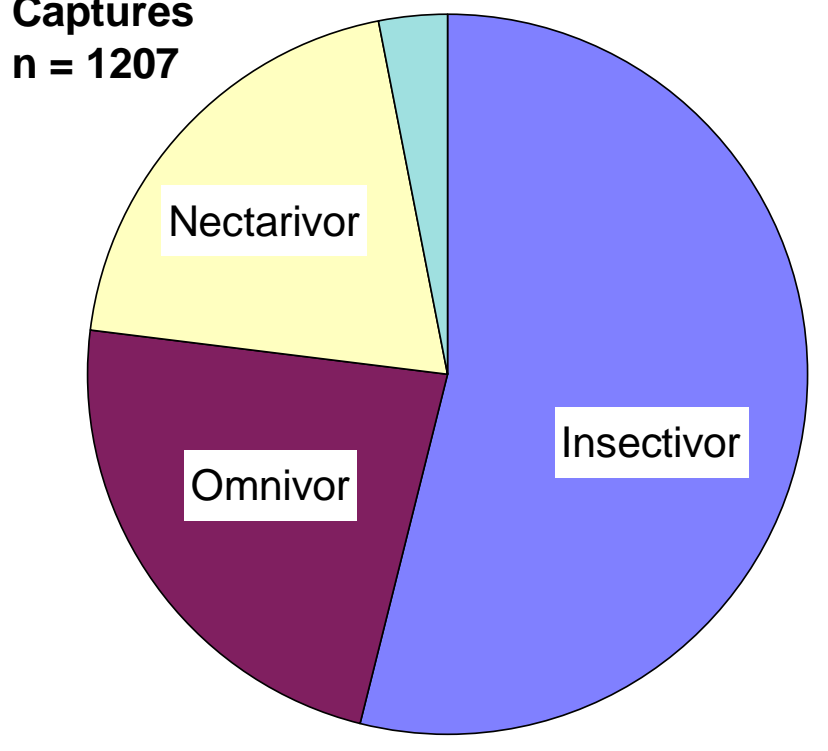

Tab. 21: Number of captures of understorey birds of different feeding guilds captured in two compartments of the Bossematié Forest, south-east Côte d'Ivoire. Significant differences between compartments are marked with a and c (Chi-sq. test, D.F.=1, $\left.\mathrm{p}_{\mathrm{a}}<0.05, \mathrm{p}_{\mathrm{c}}<0.001\right)$.

\begin{tabular}{lccc}
\hline & \multicolumn{2}{c}{ Compartment } & \\
\cline { 2 - 3 } & Control & Disturbed & Combined \\
\hline Insectivores & 349 & 300 & 649 \\
Nectarivores $^{\mathrm{a}}$ & 138 & 103 & 241 \\
Omnivores $^{\mathrm{c}}$ & 99 & 180 & 279 \\
Granivores $^{\mathrm{a}}$ & 7 & 20 & 27 \\
Carnivores & 3 & 2 & 5 \\
Frugivores & 1 & 5 & 6 \\
\hline \multicolumn{1}{c}{} & 597 & 610 & 1207 \\
\hline
\end{tabular}




\subsubsection{Comparative efficiency of mist-netting and mapping}

Of the 136 species identified on the plot, 52 species (1300 captures during standardised and occasional mist-netting) were captured in mist-nets. Only three of these species were exclusively caught in mist-nets and not mapped. 74, 83, 24 and $9 \%$ of the species of resp. understorey, lower and upper midstorey and canopy were trapped in mist-nets. At least 25 (48 $\%$ ) of the 52 mist-netted species were captured in considerably lower numbers than their estimated density. 23 species were captured in about equal and four species were captured in higher numbers than their presumed adult breeding population (e.g. Andropadus virens, A. latirostris, Nectarinia olivacea). Therefore, mist-netting alone would have given a strongly biased composition of the whole bird community when contrasted with direct counts.

\subsection{Capture rates and habitat quality: the case of the Yellow-whiskered Greenbul}

As in the analysises of the previous chapter, the habitat use of understorey birds in tropical forests is often measured in terms of capture rates or numbers of captured individuals (see Schemske \& Brokaw 1981, Levey 1988, Lambert 1992). But the often drawn conclusion that higher capture rates are generally linked to higher habitat quality remains questionable. Incomplete understanding of bird behaviour and population dynamics in secondary habitats indicates that capture rates should be interpreted with great caution. In territorial species under high population pressure, capture rates can be much higher in sub-optimal habitats than in optimal habitats. In a complex habitat mosaic, even an inverse relationship between relative abundance and habitat quality may exist due to higher movement rates of sub-ordinate individuals (Winker et al. 1995). A more reliable indicator of habitat quality is therefore the number of sedentary individuals in a given area.

For the more abundant species in the mist-net community, the number of individuals were compared with the proportion of recaptures in each compartment. Results indicated that species, for which a significant preference for a particular compartment was found from capture rates (see Tab. 20), also showed a higher number of recaptures in the respective compartment. However, in one species with no significant difference in capture rates between compartments, a statistical analysis of capture and recapture data showed a discrepancy among compartments which was not caused by sampling errors.

\section{Sedentary Yellow-whiskered Greenbuls}

Although in the Yellow-whiskered Greenbul Andropadus latirostris similar capture rates were obtained in each of the compartments, the number of sedentary individuals differed. During the sampling period 1997, several more individuals were recorded in the disturbed than in the control compartment (40 vs. 31) and also a higher capture rate was obtained (47 vs. 43). However, the number of recaptures from 23 marked and released individuals in 1996 was lower in the disturbed compared to the control compartment ( 7 vs. 15). This negative association between the number of recaptures and forest disturbance is significant $(2 \times 2$ table, $\left.\chi^{2}{ }_{1 \mathrm{df}}=4.040, \mathrm{p}=0.044\right)$.

Considering this as an indication that, in 1997, the proportion of territory holders of $A$. latirostris individuals was lower in the disturbed than the control compartment, two more 
hypotheses are derived. First, if habitat quality for the species is lower in the disturbed compartment, the average weight of individuals present should also be lower than in the control compartment. Second, due to the larger homeranges in the sub-optimal habitat (assumed to be the disturbed compartment), average distances between capture locations should be higher in disturbed than in control.

There was evidence for both hypotheses.

\section{Weight and homeranges of Yellow-whiskered Greenbuls}

First, the average weight of A. latirostris individuals captured in control was significantly higher than of those from disturbed during the sampling period 1997 (Mann-Whitney U test, Z $=1.854$, one-tailed $\mathrm{p}=0.016$ ). Second, the distances between locations where sedentary individuals were captured during the wet seasons 1996 and 1997 where higher in disturbed than control. However, due to large variation and small sample size, this was only nearly significant (Mann Whitney U test, $Z=1.553$, one-tailed $p=0.060$ ) (Tab. 22, Fig. 31).

Tab. 22: Number of individuals, recaptures, mean weight ( $\pm . s . d$.$) and mean distance between locations of$ first captures in consecutive sampling periods in a population of Yellow-whiskered Greenbuls Andropadus latirostris in two compartments of the Bossematié Forest, south-east Côte d'Ivoire.

\begin{tabular}{lcc}
\hline & \multicolumn{2}{c}{ Compartment } \\
\cline { 2 - 3 } & Control & Disturbed \\
\hline Individuals in 1997 & 31 & 40 \\
Recaptures from 1996 & $15(65 \%)$ & $7(30 \%)$ \\
Mean weight $[\mathrm{g}]\left(\mathrm{n}_{\text {cont }}=31, \mathrm{n}_{\text {man. }}=40\right)$ & $25.9( \pm 2.7)$ & $24.9( \pm 1.9)$ \\
Mean distance $[\mathrm{m}]$ between captures $\left(\mathrm{n}_{\text {contr. }}=15, \mathrm{n}_{\text {man. }}=7\right)$ & 126.8 & 178.1 \\
\hline
\end{tabular}
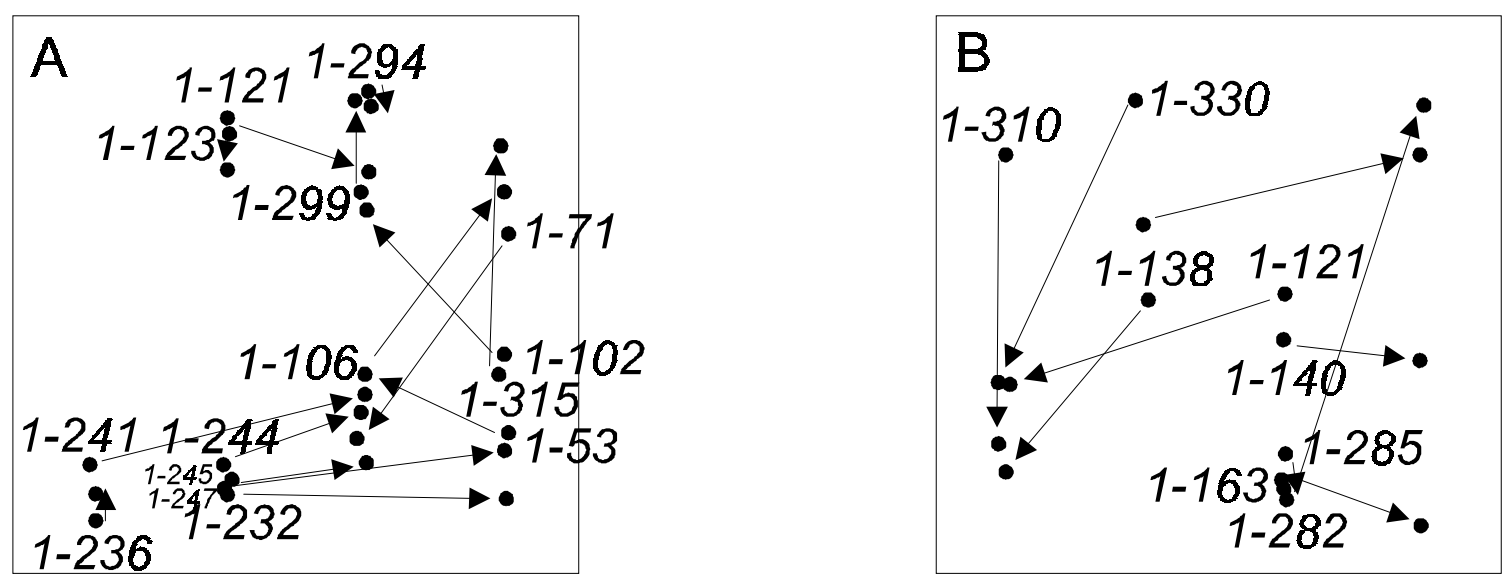

Fig. 31: Locations of captures and recaptures of sedentary Yellow-whiskered Greenbuls Andropadus latirostris in (A) control compartment $(n=15)$ and $(B)$ disturbed compartment $(n=7)$, from mist-netting in two consecutive sampling periods. The area covered by mist-nets contains appr. 16 ha in each compartment. Figures are numbers of individual birds. 


\section{Discussion}

\subsection{Logging, forest management and vegetation structure}

The vegetation classification used in this study (according to structural complexity) proved to be adequate for a general description of the overall status of the vegetation. After the logging operations during the last decades, the vegetation of the Bossematie Forest appeared as a mosaic of patches of variable structure. Repeated (over-) logging created frequent gaps in the forest, covering appr. $13 \%$ of the forest surface. At the time the study was carried out, the frequency of occurrence of gaps was higher, but not far higher than in undisturbed forests where natural gaps constitute $9 \%$ of the forest area (Poor 1968 in Schemske \& Brokaw 1981). What differed most from mature forest, was the high proportion of patches which were in an early phase of the successional development of the forest (S1 and S2, together 61\%). Patches where the foliage was more evenly distributed along a vertical profile only made up $24 \%$ of the surface. This clearly shows that the overall forest condition is critical. Hawthorne \& Abu-Juam (1995) defined characteristics for the evaluation of Ghanaian forests based on the vegetation structure. According to their scale ranging from one to six (one - excellent, six - no significant forest left), the score four has to be assigned to the Bossematié Forest ("mostly degraded", see Tab. 23).

Tab. 23: Forest reserve condition scores, established for the Ghana high forest zone (Hawthorne \& AbuJuam 1995)

\begin{tabular}{|l|l|}
\hline Score & Definition \\
\hline 1 & $\begin{array}{l}\text { EXCELLENT with few signs (<2\%) of human disturbance (logging/farms) or fire damage, with } \\
\text { a good canopy and virgin or late secondary forest throughout. }\end{array}$ \\
\hline 2 & $\begin{array}{l}\text { GOOD with <10\% heavily disturbed. Logging damage restricted or light and well-dispersed. } \\
\text { Fire damage none or peripheral. }\end{array}$ \\
\hline 3 & $\begin{array}{l}\text { SLIGHTLY DEGRADED: Obviously disturbed or degraded and usually patchy, but with good } \\
\text { forest predominant; max. 25\% with serious scars and poor regeneration; max. 50\% slightly } \\
\text { disturbed, with unbroken upper canopy. }\end{array}$ \\
\hline 4 & $\begin{array}{l}\text { MOSTLY DEGRADED: Obviously disturbed and patchy, but with a bad forest predominant; 25- } \\
50 \% \text { serious scars but max. 75\% heavily disrupted canopy. Or forest lightly burnt throughout. }\end{array}$ \\
\hline 5 & $\begin{array}{l}\text { VERY POOR: Forest with coherent canopy <25\% (more than three quarters disturbed), or more } \\
\text { than half the forest with serious scars and poor or no forest regeneration; or almost all heavily } \\
\text { burnt with conspicuous Eupatorium (=Chromolaena) and other pioneers throughout. Not, } \\
\text { however, qualifying as condition 6. }\end{array}$ \\
\hline 6 & $\begin{array}{l}\text { NO SIGNIFICANT FOREST LEFT: Almost all deforested with savannah, plantation or farm } \\
\text { etc; }<2 \% \text { good forest; or 2-5\% disturbed forest left; or 5-10\% left in extremely poor condition } \\
\text { e.g. as scattered trees or riverine fragments; remnants with little chance of surviving ten years. }\end{array}$ \\
\hline
\end{tabular}

Undisturbed tropical forests are characterised by a particularly complex vertical zonation. Up to five vertical strata have been described (e.g. Richards 1952, Pomeroy \& Service 1986). These differ from each other both structurally and taxonomically and so contribute to biodiversity (e.g. Karr \& Roth 1971, Pearson 1975, Terborgh 1980). The transition from closed canopy over midstrata to understorey and ground, represents a gradual change in abiotic (such as radiation, spectral composition of the light, temperature, humidity, wind, see Allee 1926) and biotic factors (vegetation density, tree crown structure, food availability, predators, competitors etc., see Terborgh 1980). These are reflected by differing adaptations 
and the inhomogeneous vertical distribution of species. The existence of such vertical niche occupations has been demonstrated in various animal taxa, e.g. in birds (Pearson 1971, Karr \& Roth 1971, Terborgh 1980), mammals (e.g. Bourlière 1989) and insects (Sutton \& Hudson 1980, De Vries 1988, Basset et al. 1992, Schulze 1995).

It seems obvious that an - ecologically sound - natural forest management needs to consider these relationships (see chapter 7.6).

\subsection{Composition of the avifauna}

\subsubsection{General remark}

While for other tropical regions, comprehensive documentation on the structure of forest bird communities from single sites is available (e.g. Robinson et al. 1990, Terborgh et al. 1990, Thiollay 1994b for Amazonia, Beehler 1981, Bell 1982 for New Guinea), only one African rainforest, situated in the Cameroon-Gabon lowlands, has so far been described in some detail (Brosset \& Erard 1986, Erard 1989, Brosset 1990). Especially in the Upper Guinean rainforest belt, detailed descriptions of the organisation of forest bird communities are still lacking. At the time first comprehensive surveys in Upper Guinean forests were carried out (e.g. Thiollay 1985b, Colston \& Curry-Lindahl 1986, Allport et al. 1989, Gartshore et al. 1995), large parts of the original forest cover had already been destroyed. The fact that three endemic bird species were described only in the last 25 years (two more are expected, Allport 1991), shows that there is still much left to discover about the distribution and status of the birds of the Upper Guinean forests. Because of this lack of detailed studies on Upper Guinean rainforest bird communities, it is difficult to estimate which of the avifaunal characteristics found in this study might be attributable to a logging history. However, in the following an attempt is made to evaluate the findings of this study in the light of already existing data.

In contrast to most studies concerned with logging effects on bird communities carried out in forest reserves with both logged and unlogged areas in close proximity (e.g. Holbech 1992, Dranzoa 1998), this study only deals with one isolated forest reserve, where logging occurred all over. It can therefore be expected that results are much less distorted by possible unknown compensatory influence of population pressures from nearby high-quality habitats (primary forest) into the logged areas (source-sink dynamics, see Pulliam 1988).

\subsubsection{General avifaunal composition}

Overall species composition inside the Bossematié Forest, not taking into account abundances, did not differ much from the community described for the primary moist semi-deciduous forest of the Bia reserve in Ghana (Taylor \& MacDonald 1978). Holbech (1992, 1996) similarly did not find major differences in species composition between logged and unlogged forest (Holbech 1992) or between forests of different logging regimes (Holbech 1996). Allport et al. (1989) likewise documented high species similarity (> 80\%) between logged and unlogged areas of the Gola forest (Sierra Leone) and found an almost identical species composition in mist-net samples (99\%). Gartshore et al. (1995) only list seven species exclusively recorded in primary forest and not in logged areas of the Taï National Park. Similarly, in Kibale (Uganda), Dranzoa (1998) did not report drastical changes in species composition between logged and 
unlogged forest. All these results seem consistent, and are somewhat contrasting to Kofron \& Chapman (1995), who did not observe a large percentage of the primary rainforest birds in logged forest (only 55\% species similarity between logged and unlogged forest). In the latter study, however, birds were not as exhaustively sampled as in those cited above.

A careful conclusion could be that - with only some exceptions - almost all forest birds can be recorded both in primary and in logged forest, and this even in heavily degraded areas not directly adjacent to primary forest areas. This is in accordance with Moreau (1966), who considered that one quarter of the lowland forest avifauna of Africa were species found chiefly in secondary vegetation and forest edges.

However, in the heavily degraded Bossematié Forest, at least two Upper Guinean endemics seem to be absent. According to the information from locals, one of these, the White-breasted Guineafowl Agelastes meleagrides, had been present before the logging operations started. This confirms that the species might be very vulnerable to logging (Allport et al. 1989, Allport 1991, Francis et al. 1992). Two other Upper Guinean endemics, Western-Wattled Cuckooshrike Campephaga lobata and Copper-tailed Glossy Starling Lamprotornis cupreocauda, were not recorded in the Bossematié Forest, but unconfirmed records of both species do exist (Yaokokoré \& Ellenberg, pers. comm.).

A major question in conservation biology is whether ecological influences affect different taxa in the same way (Lawton et al. 1998). Can results from one indicator group be expected to be similar for others? For the Bossematié Forest, a list of 252 butterfly species has been compiled (unpubl. data from Dall'Asta, Larsen, Fermon, documented in Larsen 1999). The number of species recorded lies well below the number of species expected for such a large area, but is better explained by under-recording than environmental effects. More interesting is the fact that the composition of the butterfly fauna corresponds well with the avifaunal data. As in the birds, the majority of butterfly species are true forest species, and data suggest that there is almost no faunal change at all, e.g. by an increase of savannah forms. Actually $92 \%$ are lowland rainforest species, and only $6 \%$ are ubiquitous or habitat specialists, whereas only $2 \%$ are savannah-centred species (Fermon 1997, Fermon et al. in prep, classification system in Larsen 1994, 1995, 1996).

\subsubsection{Species richness and diversity}

The high similarity in species composition between the Bossematié and unlogged forest areas is accompanied by a similarly high species richness. Based on mapping data, species richness inside the Forêt Classée, e.g. as mere number of species recorded within the $216 \mathrm{sq} . \mathrm{km}$ area, as well as on smaller scales (110 ha plot or smaller) is comparable to other tropical forest areas in Africa (Brosset 1990). Brosset (1990) lists c. 180 species recorded during 20 years in a 2 sq. $\mathrm{km}$ plot of undisturbed lowland rainforest in Gabon, a number comparable to the 136 species observed in this study in only 110 ha and only thirteen months field work. Neotropical bird communities are considerably richer, both Thiollay (1994b) and Terborgh et al. (1990) list in comparable studies $c$. 250 resident species per 100 or 97 ha, respectively. 
The abundance structure of the Bossematié bird community indicates some differences to primary forests. The elevated number of rare species in the spot-mapping census is responsible for the good fit of a log-series distribution, generally believed to be an indicator for disturbed communities (Magurran 1988, for tropical birds see Johns 1992, Herremans 1995). When excluding the rare species fraction from the sample, the log-normal fit is much improved, but even then abundances were far from being evenly distributed as e.g. in the community of an Amazonian rainforest bird community (Thiollay 1994b). For the moment no such data seems to exist from other African rainforests.

From mist-netting on a very small spatial scale ( 2 ha), diversity ( $\alpha$-log-series and Simpson) of birds in mist-net samples were markedly lower in the Bossematié Forest than in other Upper Guinean primary forest areas, e.g. in the Nimba (Yaokokore-Beibro \& Waltert, unpublished) or Gola forest reserves (Allport et al. 1989). Interestingly, alpha-diversity and evenness did not differ strongly between the heavily logged Bossematié and the apparently only slightly disturbed parts of the Mabi forest reserve (c. $30 \mathrm{~km}$ south of Bossematié, Eastern Côte d'Ivoire). This might indicate that already slight disturbances influence population densities of some species, in turn lowering diversity at this spatial scale. This seems contradictory to Holbech (1996), who concludes that slight logging increases diversity of birds recorded with mist-nets.

The fact that $\alpha$ (log-series) and Simpson diversity indices for 2 ha mist-net samples were higher in the disturbed compartment than in the control compartment can largely be ascribed to the occurrence of "tourists" in the sample, i.e. species that were occasionally captured in the disturbed compartment due to shifting vertical foraging niches to lower levels. Such a shift in vertical distribution can be explained by the foraging behaviour of many midstorey and canopy species which follow the contour line of the canopy reaching ground level in gaps and along logging roads. Respective species include e.g. Nigrita canicapilla, Anthreptes collaris, Macrosphenus kempi, Dicrurus adsimilis. Another (or additional) explanation could be the timing of the mist-net censuses, which were carried out during and after the main breeding season, where many young birds still accompanied adults. But it is difficult to hypothesise, which effect on diversity calculations a higher proportion of juveniles in successfully breeding species should have.

Extrapolations of species richness with the help of estimators of Chao (1984), and Chao et al. (1993) were applied to pair density data and proved to give a good description of the community of the 110 ha study plot. Estimators calculated from data obtained during the three months census were very near to the actual maximum number of species ever recorded there. From the 118 spp. recorded, calculations of the local species pool ranged between 136 and 139 spp., and the actual number of species recorded within thirteen months of field work was 136 species. Until present, extrapolations of species richness from discrete samples (Colwell 1997) has been applied mainly to rich arthropod communities (e.g. Carlton \& Robinson 1998), but it will be of interest to see if these relatively new methods will produce similarly adequate results in other ornithological studies. 


\subsubsection{Density patterns}

The most obvious differences between bird communities of unlogged forests and the highly disturbed Bossematié Forest are visible when comparing bird densities. Holbech $(1992,1996)$ already documented a decrease in densities of forest interior birds 5-10 years after logging in Ghanaian forests, where logging levels only reached 0.9 trees/ha on average. The same was concluded in the heavily logged Bossematié Forest (five to six logging cycles before 1990), but to a much higher extent. Extremely low densities were documented for two Upper Guinean endemics in particular, Rufous-winged Illadopsis Illadopsis rufescens and the Green-tailed Bristlebill Bleda eximia (see appendix E), that only occurred in less than one tenth of their natural densities. In contrast, several widespread species less common in unbroken African rainforest showed considerably increased densities. Examples are Olive Sunbird Nectarinia olivacea, Yellow-whiskered Greenbul Andropadus latirostris, Little Greenbul Andropadus virens, Green Hylia Hylia prasina (appendix E) or Brown Illadopsis Illadopsis fulvescens. Besides the obvious finding that large species generally showed lower densities than smaller species, another ecological feature seemed to be linked to density. Species from lower vertical strata tended to be generally more common than those from higher strata.

However, there could be one major objection against these findings. The lower densities of canopy species reported in this study could be an artefact due to general under-recording of species living at higher strata. At first sight, this could indeed make sense because birds in tree crowns are generally much less visible. Sightings were, however, much less important in the degraded Bossematié Forest and vocalisations played the major role in detecting individuals (> $90 \%$ of detections of solitary individuals or mono-specific groups). Therefore, a decrease in detectability from lower to higher strata is not considered a major bias.

Instead, the observed pattern is likely to reflect the real situation. In the comparisons of mistnet samples between logged and unlogged forest reserves (Tab. 6) it was shown that the heavily logged Bossematié Forest has much higher densities of understorey birds than primary forests, where the main light interception occurs and consequently the main primary production is located at canopy level (Terborgh 1980, Basset et al. 1992). Pearson (1971) documented that the vertical distribution of bird biomass and abundance is correlated with foliage density. It seems very clear that, compared to mature forests, the most productive vegetation layers of the degraded Bossematié Forest are the lower ones. Species dominating the community are mainly small to medium-sized insectivorous species exploiting the foliage of the dense growth in the understorey. One species, the Brown Illadopsis Illadopsis fulvescens, seems to be especially well-adapted to vertical climbing in the frequent liana tangles covering bare tree truncs (pers. obs.). Like this species, the Olive Sunbird Nectarinia olivacea is common in the Bossematie Forest, but scarce in primary forest, where its canopy relatives, Nectarinia cyaonolaema, $N$. adelberti and N. seimundi are more frequent observed (Gartshore et al. 1995)

The findings are apparently contrasting to the situation in Ghanaian forests (Holbech 1996), where densities of canopy species were relatively unaffected by logging. However, this could be largely due to the relatively moderate logging levels (c. 1 tree/ha) in Holbech's (1996) study areas in western Ghana. 
It has been shown that in interspecific comparisons, the size of the species' geographic range is related to local abundance and habitat specificity. This has been documented both for tropical and temperate communities (e.g. for birds and insects, see Mühlenberg et al. 1977, Bock \& Ricklefs 1983, Kattan 1992, Hamer et al. 1997) and attempts have been made to explain these patterns (Brown 1984). Whereas the above mentioned studies argue that local abundance is higher and habitat specificity lower in widespread species than restricted species, Haffer (1974) and Cracraft (1985) hypothesised that species with restricted ranges could possibly be better adapted to local conditions, and thus be competitively superior to "alien" species and be more abundant. In the Bossematié Forest, densities of both very restricted species and ubiquitous ones were low, whereas species with intermediate geographic ranges (Guinea-Congolian and African forest species) spanned a wide range from low to high densities. This is in accordance with Thiollay (1994b) who found rare and common species in either more widespread or restricted species. As there exists no comparable analysis from an undisturbed African rainforest, it is difficult to estimate whether the observed pattern is related to the present condition of the forest or to a general phenomenon. The Upper Guinean endemics in the Bossematié area do not seem to be rare in natural forests, but there is at least some variation in habitat specificity. Whereas some species such as Rufous-winged Illadopsis Illadopsis rufescens or Green-tailed Bristlebill Bleda eximia are very common - and maybe competitively superior to other species - in unmodified forests (Allport et al. 1989, Gartshore et al. 1995), they are, at the same, time vulnerable because they are habitat specific (considerable decline in logged forest areas). However, Sharpe's Apalis Apalis sharpei, usually common, seems to be less sensitive to disturbance. Likewise, the Copper-tailed Glossy Starling Lamprotornis cupreocauda seems to be both a common species and not too habitat specific. Browncheecked Hornbill Ceratogymna cylindricus is, where not hunted, a common hornbill and seems - at least to some extent adaptable to varied forest conditions. It will be interesting to discuss the results of this study in the light of once available data on primary forest bird communities in the region.

Diet is another major determinant of density. It is obvious that large carnivores are generally less abundant than members of other feeding guilds. In the Bossematié, the most abundant species were nectarivorous or insectivorous foliage gleaning species, but two other abundant medium-sized species were Yellow-whiskered Greenbul Andropadus latirostris and Little Greenbul Andropadus virens, with a mixed diet of small fruits and insects. Most "nectarivorous" species are not extremely specialised feeders, but take both insects and nectar. "Nectarivores" and mixed feeders both were significantly more abundant than specialised fruit feeding species or granivores. It might therefore be tentative to conclude that, in heavily logged forest, species with a more opportunistic feeding behaviour are more abundant than specialised feeders. This might be in contrast to results from primary forest (Thiollay 1994b) where, except from carnivorous species, marked differences in density between main dietary guilds did not occur.

The overall density of pairs on the 110 ha study plot of the Bossematie Forest (645 pairs per 100 ha) was of comparable magnitude but possibly somewhat lower than pair densities 
assessed with similar methodology in other tropical forest areas. Terborgh et al. (1990) gave a density of 955 pairs (100 ha $)^{-1}$ for an Amazonian rainforest in Peru and Thiollay (1994b) reported 829 pairs $(100 \mathrm{ha})^{-1}$ for a site in French Guiana. Brosset (1990) gives an ecological density of 3,690 birds individuals per sq. $\mathrm{km}$ for the Gabon lowlands, which may correspond to about 1,000 pairs (100 ha $)^{-1}$. An outstanding position in regard to tropical breeding bird densities is possibly held by New Guinea. The density of 3,450 pairs (not individuals!) per sq. $\mathrm{km}$ (Bell 1982) is derived from a much smaller study area and might be partly due to overestimation, but it can possibly be explained by the absence of primates and scarcity of arboreal mammals (Bell 1982). The bird densities of temperate primary forest are in the same order of magnitude than those cited above (e.g. Bialowieza, Poland, 620 pairs per 100 ha, or Hubbard Brook, New Hampshire, 700 pairs per 100 ha, see Tomialojc et al. 1984, Holmes \& Sturges 1975, cited in Terborgh et al. 1990), but biomass is much lower in these communities.

\subsubsection{Mixed foraging flocks}

It has been shown that obligate members of mixed understorey insectivores of the Neotropics are vulnerable to selective logging (Thiollay 1992, 1994a, Jullien \& Thiollay 1998). In Sierra Leone, size and species richness of mixed flocks seemed to be reduced in logged compared to unlogged forest areas (Allport et al. 1989). In the Bossematié Forest, a total of 63 species was found in flocks. This might be a reduced number as it is lower than the 92 species recorded by Allport et al. (1989) during five months in a primary forest, but the data are not directly comparable. But personal experience from other forest areas in Côte d'Ivoire (Mabi forest, Nimba forest reserve) confirms this impression, Bossematié flocks being apparently less rich in species and individuals.

In Neotropical primary forest, mixed foraging flocks are relatively stable associations with core members defending communally "flock home ranges" (results from colour banding, Jullien \& Thiollay 1998). It seems that in African primary forests, mixed bird parties do not show the same degree of stability (Brosset 1969, Brosset \& Erard 1986), but detailed studies are lacking. In the Bossematié, there was no evidence for the existence of a spatially permanent association of "core" members (see Appendix D). Although associations between certain species did exist, mixed flocks were encountered in an irregular manner all over the plot, and no indications for identifiable homeranges of flocks were found.

In the Bossematié Forest, the most regular members mixed foraging flocks were common species which also forage frequently in smaller, monospecific (family-)groups. The Shining Drongo Dicrurus atripennis and the Icterine Greenbul Phyllastrephus icterinus, two very regular "core" species in primary forest (Brosset 1964, Brosset \& Erard 1986, Allport et al. 1989), have only rarely been recorded. These and another flocking species, Fraser's Scarlet Tufted Sunbird Anthreptes fraseri, occur in high numbers in mature forests (Louette et al. 1995, Holbech 1992). So possibly, the poor abundance of these species is related to their flocking behaviour.

Associations between birds and other forest vertebrates in Africa have rarely been studied, but some are reported, e.g. between birds and small antelopes, large rodents (Brosset 1969, 
Brosset 1990), monkeys (Brosset \& Erard 1986), and even buffaloes and elephants (Ruggiero \& Eves 1998). In the Bossematié, there was no single opportunity to document any such association. Such associations are to be expected in the Bossematié area - indeed monkeyfollowing in White-crested Hornbills Tockus albocristatus is well-known by locals - but most larger forest mammals are as well very shy as also rare.

In the Neotropics, especially ant-followers are vulnerable to logging and fragmentation (Bierregaard \& Stouffer 1997). One ant-following thrush, Fire-crest Alethe Alethe diademata was a common bird in this study and did not seem to be negatively affected, neither by general forest conditions nor by liberation operations. However, there are at least two more species depending to some extent on ants: White-tailed Ant-thrush Neocossyphus poensis and Forest Robin Stiprornis erythrothorax. Both species occur in lower densities in the Bossematie Forest than in other more mature forest habitats (Brosset \& Erard 1986), and do seem to be affected by liberation thinning. The moderate logging levels of south-west Ghana, again, do not seem to affect densities of ant-followers (Holbech 1996).

\subsection{Management impact on the community}

\subsubsection{Evidence from the spot-mapping census}

A central question in this study concerned the effects of liberation thinning and plantation management on the bird community. Liberation operations as applied in the Bossematié Forest have never been subject to ecological studies. The results from the spot-mapping censuses show that, on the scale considered, species richness and diversity did not differ significantly between managed and unmanaged forest compartments. In addition, there were only slight differences in overall species composition between the liberation thinning and the control sector. However, there were obvious changes in the abundance of several species. A more or less equal proportion of species showed either lower or higher abundances in the liberation thinning area. The abundance of only one fourth of the species present remained unchanged. It is not easy to explain these changes. There was a slight tendency that species with larger geographic ranges (occurring in forests all over Africa) showed a higher abundance in the liberation thinning area. Among more restricted species, such as Guinea-Congolian species, there were similar proportions of species either with a lower or higher abundance in liberation thinning compared to control. Two of the Upper Guinean endemics, Rufous-winged Illadopsis Illadopsis rufescens and the Green-tailed Bristlebill Bleda eximia, both insectivorous understorey birds, were largely restricted to the control compartment. Sharpe's Apalis Apalis sharpei seemed to be more abundant in the liberation thinning area, whereas Brown-cheeked Hornbill Ceratogymna cylindricus was most frequently recorded in the remaining fruit trees of the plantation. Changes in abundance did not seem to be related to other features such as body size, diet or vertical foraging niche. However, in a pairwise comparison of similar-sized sectors in the control and the liberation thinning area, canopy species, frugivores and mixed feeders did tend to show a higher preference for liberation thinning. Amongst all bird taxa under study, tendencies were most pronounced in greenbuls Pycnonotidae (sixteen spp.). For more pycnonotid species than expected, the highest abundance was found in control, whereas the number of species preferring the liberation thinning area and the plantation were as expected. 
Not one single species seemed to prefer the swamp forest area. Among the warblers Sylviidae (eleven spp.), there were similar numbers of species preferring/avoiding the liberation thinning area.

\subsubsection{Avifaunal results compared to results on butterflies}

The effects of liberation thinning on nymphalid butterflies have also been studied on the study plot (Fermon et al. 1997 and in prep.). The results of this study are surprisingly similar to those from birds. While species richness (comparisons on a 75 ha scale) of banana-baited nymphalids at ground level was comparable or somewhat higher in the disturbed compartment, significant differences in the abundance of twelve species were documented. As in mist-netted birds, preference for the control compartment was significantly correlated with geographic ranges of butterflies. The liberation thinning area was avoided by species with more restricted ranges. As in birds, species richness and diversity were influenced by a shift in vertical distribution of canopy flyers (Charaxes spp.) that were more easily captured in the liberation thinning compartment, although they probably also occur in the canopy of less disturbed forest (Fermon et al. 1997 and in prep.).

\subsubsection{Impact assessment by mist-netting}

The design of the mist-net study was aimed to document the sometimes shy and skulking understorey birds in two vegetationally distinct areas of the study plot, the control compartment and the most distinct part of the disturbed compartment. It was hypothesised that the already low tree cover in the swamp forest area and the frequent treefalls in the liberation thinning area represented a less suitable habitat for understorey birds than the control compartment, which was situated at higher slope levels and showed an apparently good natural regeneration. At first sight, this did not appear to be so, since species richness, species diversity and species composition tended to be similar between the two 16 ha areas, and there was even an overall higher capture rate in the disturbed compartment. However, there were some very important indications for the validity of the initial hypothesis. First, from relationships between single-sample species richness ( $\alpha$-level) and $\beta$ - turnover among samples (rarefaction according to Colwell 1997), the local (extrapolated) species pool was estimated to be higher in the control compartment. Second, species with restricted geographic ranges had an overall higher proportion of captures in the control compartment, whereas for widespread species the inverse was found. In addition, larger species (indicated by weight) showed a higher preference for the control compartment than smaller ones. This was especially visible within one family, the greenbuls Pycnonotidae. Among the mist-netted species also some midstorey and canopy dwellers were found, but compared to true understorey species, they were more often captured in the disturbed compartment. This lead to the conclusion that the community comparisons (especially diversity on $\alpha$-levels) between compartments had been considerably influenced by shifts in vertical distributions of species. This conclusion was supported by spot-mapping data that documented high densities of midstorey species (e.g. Kemp's Lonbill Macrosphenus kempi) in the control compartment, which were only captured by mist-nets in the disturbed compartment. 
From analyses on species level it might be concluded that one third of the mist-netted species were negatively affected by the disturbances created. Actually, this number would certainly increase when more data were available from species with naturally low abundance such as many larger species or those with restricted ranges.

\subsection{Inferring habitat quality from capture rates}

The Yellow-whiskered Greenbul Andropadus latirostris is an insectivorous-frugivorous understorey greenbul (Pycnonotidae) of African primary and secondary forests (see Mattes \& Gatter 1989, Keith et al. 1992). The species is sexually monomorphic and sub-adults moult quickly into adult plumage. It has a remarkably variable territorial behaviour. Whereas male individuals in Gabon, where densities are exceptionally high, show a typical lek mating behaviour and only defend the close proximity of their nest (Brosset 1981, 1982), populations in Kenya, Uganda and Upper Guinea are monogamous and territorial (Keith et al. 1992, Lens et al. 1996, Holbech 1992). Especially in logged semi-deciduous forests the species seems to be abundant (Holbech 1992, Dranzoa 1998). Within the study period (between February/March 1996 and July/August 1997), the population marked during one mist-netting census increased from 49 to 59 individuals and represented the most abundant species trapped in mist-nets. Capture rates in 1997, when the population density was highest, were similar in both the control and the disturbed compartment but the disturbed compartment possessed fewer sedentary individuals. There was evidence for this conclusion from recapture rates, body weight and movement data (Waltert \& Mühlenberg 2000).

High population densities in sub-optimal habitats are frequently described in territorial mammals (States 1976, Van Horne 1982), with often juveniles or subordinate individuals as inhabitants (Van Horne 1982). The results of this study are also in accordance with Winker et al. (1995), who recorded higher movement (=capture) rates of non-territorial (sub-ordinate) wintering wood thrushes Catharus mustelinus in disturbed areas compared to control site individuals. Winker et al. (1995) excluded territorial animals (determined by radio-tracking, colour-banding and recapture data) from the analysis because net shyness, believed to be higher in territorial birds, could have influenced results. In this study, no such ommisson was done because of the difficulties to separate exactly the territorial from the non-territorial birds. However, net shyness is unlikely to have influenced the results, because the mist-net line was set only for 10 daylight hrs per site, only half the period usually used in tropical forests. In addition, each netting site was $100 \mathrm{~m}$ distant from the next and subsequent netting periods were separated by several months. Moreover, if there was any bias, it should have lowered recaptures in the control compartment, since nets are better visible there than in the dense understorey of the disturbed compartment. Actually, the results showed the contrary.

Evidence for the differing status of individuals captured in the two compartments was additionally inferred from weight data. The mean weight of individuals in the disturbed was one $\mathrm{g}$ lower than in the control compartment. Similarly, sedentary individuals of the Yellowwhiskered Greenbul in lowland rainforest of Gabon were found being heavier than non- 
territorial individuals (Brosset 1981, 1982). The weight difference between individuals recaptured and not recaptured was even higher, amounting to two $\mathrm{g}$.

At present, only speculations can be made on the reasons for the difference in habitat suitability between compartments. Possibly, interspecific competition plays a major role (see Robinson \& Terborgh 1995). Another common greenbul living syntopically is Little Greenbul Andropadus virens. The species is morphologically similar, of similar size, uses the same food and also inhabits the lower forest understorey (Mattes \& Gatter 1989, Keith et al. 1992). In contrast to the Yellow-whiskered Greenbul, the Little Greenbul seems to be able to build up viable populations in the deforested matrix of the cultivated land (Mattes \& Gatter 1989, Kofron \& Chapman 1995). On the study plot, the Little Greenbul is mainly found in bushy areas, for example around manually cleared plantations or along roads, whereas its congener Andropadus latirostris prefers closed forest. However, in the disturbed compartment both species are trapped in high numbers. In Andropadus species, interspecific competition could indeed produce habitat shifts. Andropadus virens was also found in closed canopy patches of the Lama forest, Benin, an area where Yellow-whiskered Greenbul does not occur (Waltert \& Mühlenberg 1999). But good data on interspecific relationships between species do not exist. Other factors possibly responsible for differing habitat qualities could of course be food, feeding substrate or nesting site. However, as the ecology of African forest birds is still only poorly known, only speculations can be made.

The summed up number of overall mist-net captures (all sampling periods and all species combined) did not differ between the disturbed and the control compartment, but significantly more individual birds were captured in the disturbed compartment, which suggests that the relationship found for Yellow-whiskered Greenbuls might be significant for other, more uncommon, species too. However, results comparable to those from Yellow-whiskered Greenbul were not found for any other species. Furthermore, it is possible that the slight difference in species composition between the compartments can additionally explain this result. Higher overall individual turnover in the disturbed compartment could be explained if the species there generally have shorter life-spans (sampling periods were separated by more than five months) or only occur as "tourists" (e.g. as occasional visitors from higher strata, due to the more open nature of the disturbed compartment). There is some evidence for the first explanation (shorter life spans): preference for the less disturbed control compartment was positively correlated with body size which, in turn, is linked to life history. The "tourist" theory might as well be acceptable since several small midstorey and canopy species (e.g. Kemp's Longbill Macrosphenus kempi or Nigrita canicapilla) were only (occasionally) captured in the disturbed compartment, where they were also mapped, whereas in the control compartment they were only mapped but not captured.

\section{Winker's model on movement rates}

The data on Yellow-whiskered Greenbuls can be described by a more general theory. Territoriality is the most widespread social system in birds. The evolutionary driving mechanism behind is high intraspecific competition (Brown 1964). Strong species-specific 
competition and increasing population density forces socially subordinate individuals more and more into sub-optimal habitats. Such a situation can strongly influence movement rates, as shown in Fig. 33 (after Winker et al. 1995). Fig. 32 shows the potential movement patterns and proportions of territorial individuals in three adjacent habitat types of differing habitat quality. In the optimal habitat (a), a high percentage of individuals should be territorial and this percentage should be correspondingly decreased in the other habitats (b and c). In the optimal habitat, there should also be a lower individual turnover due to many individuals, effectively defending territories against intruders. Contrarily, there should be a much higher individual turnover (few territorial individuals, many individuals still searching habitats of better suitability) in less optimal habitats. Given such a constellation, capture rates could be lower in optimal habitats than in sub-optimal habitats (habitat quality and relative abundance inversely correlated). High capture rates in sub-optimal habitats could be increased also due to larger homeranges in sedentary individuals. The model's theoretical basis is in accordance with theories on population regulation (Brown 1969, Fretwell \& Lucas 1970, •omnicki 1978) and source-sink population dynamics (Pulliam 1988)

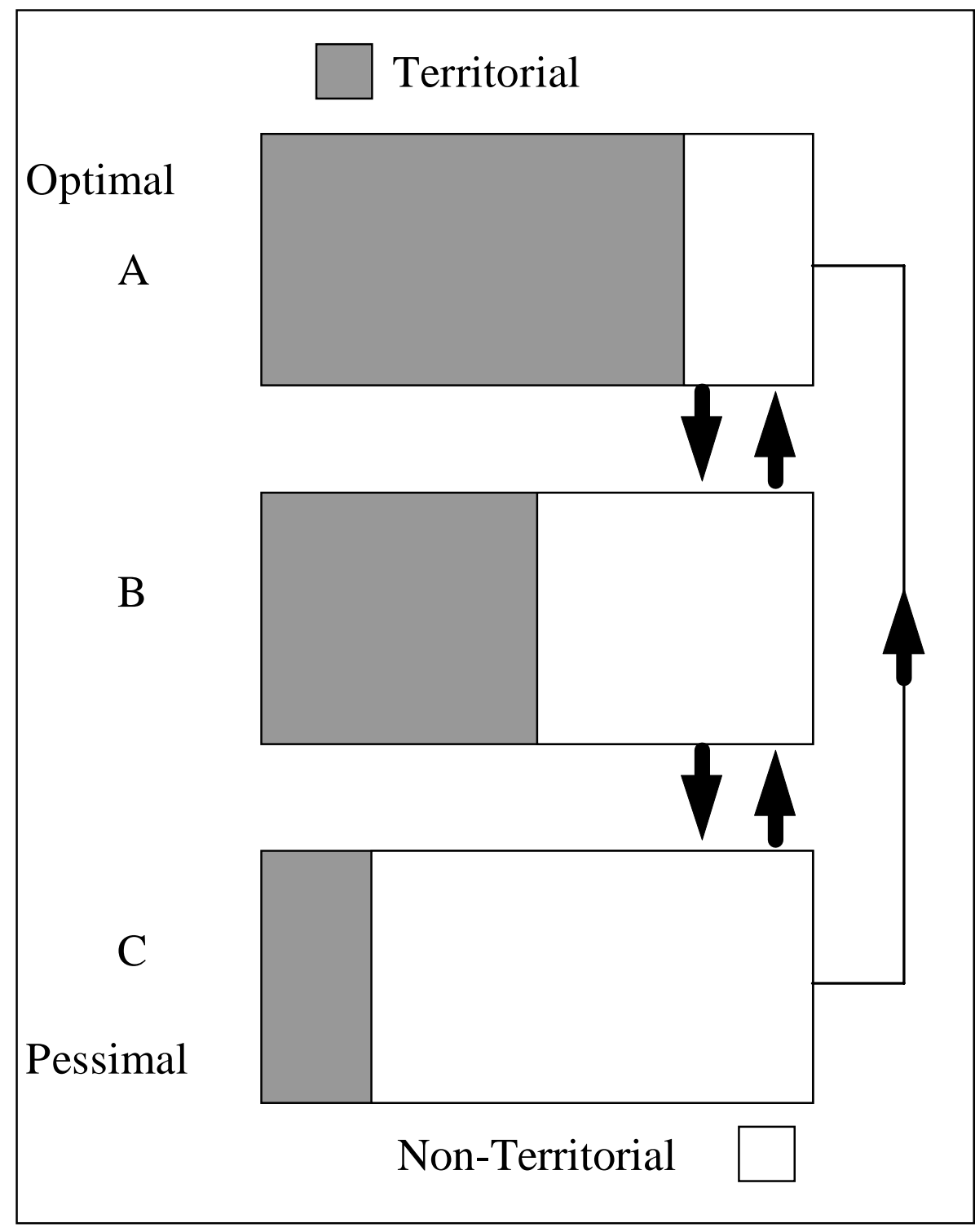

Fig. 33: Graphical model showing movement patterns of non-territorial individuals between (a) optimal, (b) sub-optimal and (c) pessimal habitats (after Winker et al. 1995). 


\subsection{Are Upper Guinean forest birds ecologically resilient?}

From a taxonomical and biogeographical point of view, the Upper Guinean forest avifauna has been described as an impoverished version of the Congolian (Louette 1999). It is characterised by comparatively low species richness and a low degree of taxonomical distinctiveness (no endemic genus, and comparatively few endemic species), most of the unique elements seem to have vicariants in the Congolian region (Louette 1999). It has been shown that the Upper Guinean forest biota contains not only fewer relictual taxa than e.g. the Cameroon-Gabon lowlands, but also fewer neo-endemics (Fjeldså \& Lovett 1997), which evolved in montane refuges during climatically stable periods (Fjeldså 1994, Fjeldså 1997, Fjeldså \& Lovett 1997, Roy 1997). Possibly, the evolution of Upper Guinean avifauna was much more influenced by forest reduction processes than Congolian fauna. It is expected that forest species surviving the ecological changes in the Pleistocene and those who recolonised the area from palaeoclimatologically more stable regions should exhibit ecological adaptations to changing environments and/or have comparatively good dispersal abilities.

In a review of the existing literature on responses of tropical forest birds to habitat degradation and fragmentation, Danielsen (1997) postulates that bird communities of palaeo-ecologically stable areas should be more prone to human-induced extinction than those evolved in areas with strong climatological changes. This hypothesis is a facet of the more general ecological theory that increasing complexity is connected with a decrease in stability (May 1972 undermining older viewpoints, e.g. MacArthur 1955, Elton 1958 in Danielsen 1997). The similar view that communities in eco-climatologically stable regions are often characterised by a combination of fragility and complexity, whereas those of environments that have undergone large and erratic climatic changes are relatively robust and simple, is even found in student textbooks on ecology (e.g. pp. $762-783$ in Begon et al. 1986). However, Danielsen's hypothesis is supported by only few field studies which do not provide a good basis for rigorous testing. Comparisons of impact assessment studies between continents are constrained by the lack of suitable controls, incomparable census methods, inadequate descriptions of disturbance regimes, and differences in disturbance intensity (Danielsen 1997).

However, a close look on the biology of forest birds from continents with different palaeoclimate supports well the idea. There is an overall lack of specialisation in African compared to Neotropical birds and - at least to some extent - also compared to the South East Asian fauna. A low degree of specialisation seems to be visible in many ecological features of the avifauna, e.g. habitat, food, or behavioural traits. African bird communities lack the diversity of large ground-dwelling forest fowl of America (tinamous) and South East Asia (phasianids). In addition, Africa lacks a diverse and specialised bark-dwelling guild such as the Neotropical tree-creepers (Dendrocolaptidae). Instead, bark feeding in African forest species seems to be an opportunistic behavioural trait in bulbuls such as Yellow-throated Olive Greenbul Criniger olivaceus, or weavers such as Red-headed Malimbe Malimbus nitens or Preuss' Weaver Ploceus preussi (with most probably granivorous weavers as ancestors!). (West-)African sunbirds are also much less specialised than Neotropical hummingbirds (Lock 1986). 
Specialised flycatchers, a large and diverse guild in Neotropical forests, are considerably less rich in Africa, too. So, it seems that many ecological niches occupied by specialists in Neotropical forests still await a specialised bird in Africa. Another striking feature is the fact that most African forest birds can be found in good densities in all major forest types, from mangroves to gallery forests, whereas there is strong specialisation on habitat types in both South America and South East Asia (Keast 1990).

Many African forest species are derived from true savannah taxa, e.g. the insectivorous forest weavers of the genus Malimbus (Ploceidae) whose bill morphology do not even differ from their savannah relatives in the genus Ploceus (Din 1991). Other examples are estrildid finches from the genera Nigrita or Mandingoa (Estrildidae), whose relatives are also granivorous open-land species. More detailed and quantitative comparisons of niche characteristics of Neotropical and African forest birds are made by Erard (1989), indicating that niches in African guilds are both less broad and to a lesser degree tightly packed with species. While broader guild niches accounted to $40 \%$ for the higher Neotropical species richness, tighter species packing was found to be responsable for the remaining 60\% (Erard 1989).

These facts, the logging studies of Holbech $(1992,1996)$, and the finding that the degraded Bossematié Forest still holds populations of almost all species to be expected in the study area might confirm Danielsen's (1997) hypothesis. However, it might still be too early to draw firm conclusions from supporting data. We do not yet know much about the complex population dynamics of forest birds and we do not yet have firm ideas on the time lags operating in the extinction processes of vertebrate species (Brooks \& Balmford 1996, Brooks et al. 1999). At least one species, the White-breasted Guineafowl Agelastes meleagrides, can be considered definitely extinct in the Bossematié area as a consequence of the past logging operations. But deforestation and over-logging might still be very recent phenomena compared to the (possibly) long life spans of many bird species. A decline in the Afep Pigeon Columba unicinta in the Bossematié Forest has e.g. only been demonstrated recently (Mühlenberg et al. 1999, Mühlenberg \& Waltert 2000.), indicating that only long-term ecological monitoring can help us in identifying those undesired trends.

\subsection{Considerations on forest management}

\section{General remark}

Forests in Eastern Côte d'Ivoire are and will be production forests. Sustainability in the sense of maintaining biodiversity must guarantee the presence of the species in the area by preserving viable populations. Particularly in a naturally managed forest, where 70 to $95 \%$ of the trees are animal-dispersed (Waitkuwait 1992), forest management should pay attention to the restoration of its animal populations. It seems unlikely that key species like hornbills and turacoes are able to maintain their ecological functions as seed dispersers, when they only occur in one tenth of their natural density. Results from this study indicate that inside heavily logged rainforests, densities of most typical forest species are largely reduced compared to densities in mature African forests, which in turn suggests that serious declines must have occurred. The populations of some of the forest birds, especially the Ceratogymna hornbills, 
are already very small and their conservation status must be considered as critical. It is therefore rather questionable whether remaining populations are viable on a long-term basis.

\section{Liberation thinning}

The importance of a natural vertical vegetation structure for the forest biota has been described in chapter 7.1. If forest management wants to consider these relationships, the conservation of as many as possible remaining "residual" mature forest patches should be the major objective, rather than to produce a further shift in the composition of the vegetation to younger succession stages. In the Bossematié Forest, however, liberation thinning operations obviously increased the number of gaps and reduced the proportions of older succession stages, a conclusion which was also confirmed by detailed analyses of vertical foliage distribution (Bamba 1999 using methods of Chatelain 1996) and underlined by density measurements of understorey trees (this study). In this sense, the view that natural forest management only mimics natural forest dynamics is a severe over-simplification.

It should be kept in mind that liberation thinning on the study plot was only carried out on a small spatial scale. Birds are relatively mobile and the liberation thinning and the control area were directly adjacent to each other. The impact on birds (and butterflies, Fermon et al. in prep.) will be even higher than results from this study suggest as thinning operations will be carried out on larger scales (e.g. in the Bossematié Forest: on more than one third of its surface, SODEFOR 1994). The special danger of creating initial damage by liberation thinning operations should be taken in particular consideration in a forest where Forest Elephants (Loxodonta africana cyclotis) are present. Struhsaker (1997) documented a decreased survival and growth of seedlings and saplings by increased utilisation of open areas by elephants. Furthermore, damage increases the vulnerability of the forest stand to wind-throws (the last affecting the Bossematié area occurring only in 1997).

When the management policy claims (1) to enhance forest regeneration after logging and (2) to integrate the management with the conservation of biodiversity and ecological integrity, it seems clear that any incidental damage must be kept to an absolute minimum. Therefore, liberation thinning, as currently practised in the Bossematie Forest, should be re-evaluated critically. The most prominent impact of liberation operations is due to the girdling of secondary trees. As a consequence, girdling should be reduced to a minimum where possible. Climber cutting in degraded forests, however, seems to be in accordance with both, ecological and economical objectives of forest management. It has been shown that the superabundant climbers of heavily logged forests severely impede tree regeneration and increase damage after treefalls (Struhsaker 1997).

If liberation operations cannot be adjusted because of economical reasons, the applied technique deserve further monitoring. At present, only bird and mammal species are monitored in south-east Côte d'Ivoire (Waitkuwait 1992, Mühlenberg et al. 1995, 1999). Their population responses appear only with long time-lags (Brooks et al. 1999) and are not as easily detectable as in invertebrates (Murphy \& Wilcox 1986). Additional monitoring with 
invertebrates such as butterflies could guide management on a smaller scale and over shorter periods and is therefore recommended.

\section{Plantation management}

Due to frequent manual clearing of the regenerating vegetation, the Terminalia-plantation on the study plot did not show major understorey succession. A monolayered canopy and a complete lack of diverse understorey vegetation were characteristic. However, in parts of the plantation, Terminalia/Triplochiton trees seemed to be less well-developed and several umbrella trees (Musanga spp.), producing large amounts of fruit during the census, were left standing there. These were regularly visited by group-living Gymnobucco-barbets (three colonies in dead trees within the plot), as well as Great Blue and Verreaux Turacoes Corythaeola cristata, Tauraco macrorhynchus. At the plantation border, also many young trees Trema spp. produced fruits which were readily taken by Andropadus and other greenbuls. Flowering lianas also attracted various sunbird species. These resources allowed interesting and easy observations of a high number of species. However, with the exception of some ubiquitous insectivorous/omnivorous species (Grey-backed Camaroptera Camaroptera brachyura, Common Bulbul Pycnonotus barbatus, Little Greenbul Andropadus virens), and the granivorous Ahanta Francolin Francolinus ahantensis, none of the recorded species seemed to establish a complete territory in the plantation. Although the availability of several resources can improve the habitat quality for many species, it is very unlikely that plantations in the described state play an important role in maintaining the forest interior fauna. Established on a larger scale, but managed with the same intensity, this habitat type would most likely not have produced similar numbers of individuals and species. Bird faunas in large high-intensity plantations seem to be extremely impoverished. Most extreme in this respect is Teak Tectona grandis. These plantations do not provide major food sources such as fruits or insects (Teak is almost free from insect attack). At Ibadan, Nigeria, less than ten (!) bird species were recorded in Teak in fifteen (!) years (Elgood et al. 1994). As is foreseen in the management plan of the Bossematié Forest (SODEFOR 1994), plantations should be established only in areas with extremely low natural regeneration potential. Furthermore, it would be very useful to stop manual clearing at ground level, when planted trees have attained sufficient height to be free from competition. It has been shown that older plantation systems with a luxuriant understorey can provide a much better basis for the conservation of the forest interior fauna (Gartshore $e t$ al. 1995).

\section{Biological reserves}

In the Bossematié Forest, three biological reserves covering one third (7404 ha) of the total forest area have been established. At the time of the study, these areas did not yet represent a different type of forest. However, it seems evident that they already played an important role for the conservation of biodiversity. Located at the centre of the forest, these areas have been shown to be important for large hornbills, which increasingly use the core area of the Bossematié Forest, probably because poaching is less than at the forest margins (unpubl. reports of Mühlenberg et al. 1997, Mühlenberg et al. 1999). Biological reserves are believed to play a very important role inside production forest (Johns 1996, 1997). They serve as 
recolonisation areas from which forest interior species can disperse and recolonise regenerating habitats suitable for successful breeding. A second type of biological reserve inside the Bossematié Forest is represented by the valley bottoms (e.g. the swamp forest area of the study plot). Heavy logging machinery affected these areas much more than at higher slope- or watershed level (soil compaction). They have now a very open character with insignificant tree cover (see Fig. 7, appendix E) and it seems logical to exclude these areas from intensive management measures and timber exploitation in the future.

\section{Control of poaching}

Poaching and bushmeat trade have reached critical levels in West and Central African rainforest areas (e.g. Rose 1998, Bowen-Jones 1998). This is true also for the Bossematié and other Forêts Classées in Côte d'Ivoire (Caspary 1997, McGraw et al. 1998, Nett 1999). Most large mammal populations already are severely threatened, and their viability remains questionable even when illegal hunting would immediately be stopped. Among the birds, especially the large hornbills Ceratogymna spp. are badly affected. It would be important to take effective measures to stop illegal hunting in protected areas such as the Forêts Classées, at least until animal populations have recovered. However, with the present socio-economic situation this is a heavy task. A controlled-hunting program in forest reserves at this early stage of forest rehabilitation is no alternative, because it seems impossible to control off-take neither quantities nor selection of not-threatened species. It seems likely - because of the unpredictable nature of animal encounters in tropical forests - that local hunters will not respect hunting bans of selected species. Consequently, population declines in species with low reproductive rates (larger primates, hornbills) would be expected, even when hunting is officially focused on species able to compensate high losses by increasing their reproductive rates (documented for duikers by Hofmann et al. 1998). Hunting canopy species in logged areas is much more easy, because visibility in higher strata is facilitated (Holbech 1996), another reason for the re-establishment of a closed canopy within the rehabilitation program.

\section{Reserve size}

Besides habitat quality, size and isolation play an important role in conservation management in general (see "island ecology", MacArthur \& Wilson 1967) and of course particuarly in West African forest reserves, especially when considering vertebrate populations. Holbech (1996) found forest reserves in south-west Ghana of less than $50 \mathrm{sq}$. $\mathrm{km}$ to be extremely vulnerable to bird species loss at even low disturbance levels. In those reserves, extraction levels of 0.5 / ha already had adverse effects on the survival of many species. Even in intact forests of this size, several species may not be able to survive, as e.g. the large Ceratogymna hornbills of which absence is very easy to detect. In contrast, from avifaunal composition of larger reserves (>300 sq. km), Holbech (1996) suggested logging levels of not more than c. 2 trees/ha, a sufficiently long regeneration time (20 years for forest birds to recover) and reserve sizes of $>300 \mathrm{sq} . \mathrm{km}$ being fairly sustainable. Inside the Bossematié Forest (216 sq. km), the large Ceratogymna hornbills are already much reduced in numbers (Waltert et al. 1999). 


\section{Summary}

1. The avifauna of the Bossematié Forest, an isolated and heavily logged Forêt Classée of 216 sq. km size in south-east Côte d'Ivoire, was studied five years after the last logging operations. The avifauna was censused by standardised mist-netting and spot-mapping on a 110ha study plot including different compartments: a tree plantation, a disturbed compartment with a swamp forest area and a liberation thinning area, as well as a less disturbed control compartment. The impact of the forest management on the bird community and the vegetation structure was assessed. In addition, the overall status of the vegetation in the forest was surveyed from sixteen $2-\mathrm{km}$ line transects.

2. In 1996, the forest had the typical appearance of a residual forest. $61 \%$ of its surface consisted of young secondary growth with mono-layered canopy on low levels, only $24 \%$ contained a multilayered canopy and $13 \%$ of its surface were gaps.

3. The percentage of gaps was significantly higher, but the percentage of older succession stages was lower in the liberation thinning compared to the control area. Size and density of overstorey trees $(>10 \mathrm{~cm} \mathrm{dbh})$ seemed to remain unchanged by liberation thinning, but the density of understorey trees $(5-10 \mathrm{~cm}$ dbh) increased significantly.

4. A five-years old Terminalia plantation consisted of an even-aged stand with a closed canopy, tree sizes were comparable to those in the control compartment, but trees were significantly more distant from each other. In addition, there was a definite lack of understorey vegetation due to repeated manual clearing.

5. Natural forest in the swamp forest area had a significantly lower size of overstorey trees, but neither their dispersion, nor the density of understorey trees $(5-10 \mathrm{~cm}$ girth) was significantly different from the control compartment (mid- or higher-slope level).

6. A total of 236 bird species was recorded in the Bossematié area, including observations from the surrounding. Overall avifaunal composition in the Forêt Classée was very similar (Soerensen=0.92) to that in the Bia National Park, Ghana, and this comparison is based on a species list from 1976, when most of the Bia reserve was still unbroken primary forest. 113 bird species belonged to the biome-restricted assemblage of the Guinea-Congo Forests Biome, which constitutes $61 \%$ of all Guinea-Congolian species known from Côte d'Ivoire. Four Upper Guinean endemics were found, unconfirmed records of two additional ones exist. One more, the White-brested Guineafowl Agelastes meleagrides, formerly occurred in the area, but has not been recorded after the logging operations. Five bird species are officially classified as species of conservation concern in Côte d'Ivoire. A striking difference between the bird fauna of the Forêt Classée and the surrounding area wa found: $70 \%$ of the species present inside the forest (110 out of $159 \mathrm{spp}$.) were never recorded in the surrounding farmland.

7. Alpha-diversity and evenness of understorey birds from mist-net data within 2-ha areas were lower than in lowland primary forests of Côte d'Ivoire (Nimba) and Sierra Leone (Gola), but comparable to other, only slightly disturbed lowland areas in Côte d'Ivoire (Mabi forest reserve).

8. 118 bird species in 709 pairs were found to be resident on the 110 ha study plot during a three months census (June-August 1997). Extrapolated species richness for the 110 ha plot 
was estimated at 136 to 139 . The same number of species, namely 136 , was the total number recorded on the plot during the whole thirteen months study period.

9. The community was dominated by four species occupying lower forest strata: Yellowwhiskered Greenbul Andropadus latirostris, Brown Illadopsis Illadopsis fulvescens, Green Hylia Hylia prasina and the Olive Sunbird Nectarinia olivacea. The abundance distribution did not differ significantly from the log-normal distribution. However, the proportion of'very rare" (< 0.25 pairs/100 ha) species was much elevated, the difference from logseries distribution only slight. Evenness was lower than in the broken-stick communities of Amazonian primary lowland forest.

10. Breeding pair densities were principally related to the species' vertical stratification, not to their geographic range. In an interspecific comparison, there was a significantly negative correlation between foraging height and density. There was no correlation between the size of geographic range and abundance, Guinea-Congolian (excluding Upper Guinean endemics) and African Forest species showed both rare and common species, Upper Guinean restricted and ubiquitous species showed low overall densities. However, comparing densities with relative abundance data from primary forests, a higher percentage of the Upper Guinean endemics and Guinea-Congolian species showed lower densities than in primary forest, whereas the same was found in only few African Forest but not in ubiquitous species. Likewise, most hornbills showed lower densities than in primary forests.

11. 63 bird species were members of mixed species flocks. Flocks tended to be smaller and seemed to consist of fewer species than those known from unlogged forests. Species of the understorey and lower midstrata tended to be more regularly encountered in mixed flocks than species of higher strata.

12. On a small scale (18.3 ha), species richness and diversity of birds did not differ significantly between liberation thinning and control. However, species richness and diversity on 32 ha level was lower in the liberation thinning area. Species abundance patterns did not differ between control, liberation thinning, swamp forest and plantation and were not significantly different from log-normal nor log-series models.

13. Species composition changed markedly on a small scale (18.3 ha) between control, liberation thinning, swamp forest and plantation. Turnover was higher between control and swamp forest or plantation than between control and liberation thinning.

14. In interspecific comparisons, habitat preferences were best explained by the species' geographic range, while diet, body size or vertical stratification were not related to habitat selection. Whereas an equal proportion of Guinea-Congolian (excluding Upper Guinean) species preferred/avoided the liberation thinning area, more African Forest species than expected preferred this area. Ubiquitous species reached highest abundances in the tree plantation. Most pycnonotid species showed highest abundances in the control compartment, while in sylviid species, no specific vegetation type was preferred.

15. Understorey birds were mist-netted in successively larger (nested) areas of the control and the disturbed compartment. Species richness and diversity of understorey birds on a small scale ( 2 - $8 \mathrm{ha}$ ) were higher in the disturbed than in the control compartment, but there was no difference on larger scales (16 ha) and estimators of true species richness were higher in control than disturbed. Species composition of understorey birds was similar between control and disturbed (Morisita-Horn $=0.80$ ). 
16. An interspecific comparison of capture rates of understorey birds was carried out. Habitat preference was expressed as the proportion of captures obtained in the control compartment from all captures obtained in both the control and the disturbed compartment. First, habitat preference was significantly correlated with the size of the geographic range. Species with narrow geographic ranges tended to have a higher proportion of captures in the control compartment than geographically more widespread species. Second, there was a significantly positive correlation of habitat preference and body size. Capture rates of larger species (almost only insectivorous passerines) were higher in the control than in the disturbed compartment, the correlation being strong in greenbuls Pycnonotidae. A third feature correlated with habitat specificity was vertical foraging height. Lower foraging species tended to be more specific than those of higher strata.

17. Eight species exhibited significant differences in capture rates between the disturbed and the control compartment. Overall capture rates of understorey birds (all species and all sampling periods combined) did not differ between disturbed and control, but the number of individuals trapped in the disturbed compartment was significantly higher. In one species, the Yellow-whiskered Greenbul Andropadus latirostris, there was a significant proportional difference in the number of individuals captured and the proportion of recaptures between disturbed and control. While the number of individuals captured was higher in the disturbed compartment, the proportion of recaptures in that area was lower. In addition, the mean weight of individuals captured in the disturbed compartment was significantly lower than in those from the control compartment, indicating that there should be a major difference in habitat quality for this species. 


\section{Résumé}

1. La communauté des oiseaux du forêt classée de la Bossematié, une îlot forestier fortement exploitée de $216 \mathrm{~km}^{2}$ dans le sud-est de la Côte d'Ivoire, est décrite. La recherche était conduite cinq années après la dernière exploitation forestière. L'avifaune était enregistrée à l'aide des captures au filet japonaise et à la méthode du spot-mapping sur une superficie de 110 ha. La zone d'étude comprenait différentes compartiments: une plantation forestière de cinq ans, une parcelle expérimentale avec une zone marécageuses et une zone d'éclaircie sélective, ainsi qu'une zone non-traitée de contrôle. L'impact de l'aménagement forestier sur la communauté des oiseaux est étudié. En plus, la condition générale de la structure de la végétation dans la forêt classée était étudiée sur seize transects de deux $\mathrm{km}$ chaque.

2. Les résultats sur la structure de la végétation forestière montre que $61 \%$ de la superficie est couverte de jeune forêt secondaire, $13 \%$ des trouées, soit naturelle (chablis) soit créé par l'exploitation. Sur uniquement $24 \%$ de la superficie, la stratification verticale du feuillage ressemblait à une forêt mature caractérisée par une distribution plus homogène.

3. Le pourcentage des trouées était élevé dans la zone d'éclaircie sélective. Par contre, les pourcentages des stades de succession plus mature y étaient réduits. La grandeur et la densité des arbres de la cime (>10 cm dbh) ne semblaient pas avoir changées par l'aménagement, par contre la densité des jeunes arbres $(5-10 \mathrm{~cm} \mathrm{dbh})$ y était élevée.

4. Une plantation forestière de Terminalia spp. constituait d'une population d'arbres de cinq ans avec une cime fermée. La taille moyenne des arbres était paraille à la taille moyenne des grands arbres dans la forêt naturelle, mais la distance entre eux était plus grande. En plus, en dessous la cime de la plantation le sous-bois n'a pas pu développer à cause de l'éclairement manuel fréquemment conduit.

5. La taille moyenne des arbres de la cime était plus petite dans les bas-fonds, mais ni leur dispersion, ni la densité des jeunes arbres $(5-10 \mathrm{~cm}$ dbh) ne différaient de la forêt des collines.

6. Un total de 236 espèces d'oiseaux était enregistré dans la région de la Bossematié, inclusivement les observations occasionnelle dans le paysage autour. La richesse et la composition spécifique dans la forêt classée étaient très semblables (index de Soerensen=0.92) à celle du Parc National de Bia au Ghana, la comparaison étant basée sur une liste d'oiseaux établie en 1976, quand la plupart de la Bia réserve se composait encore de forêt primaire. 113 espèces de la Bossematié étaient des espèces inféodées aux forêts du Guinée-Congo et représentaient $61 \%$ de toutes les espèces de répartition paraille connues dans la Côte d'Ivoire. Quatre espèces endémiques dans la région de Haute Guinée étaient trouvées, pour deux espèces additionnelle des observations non-confirmées existent. Cinq espèces sont menacées en Côte d'Ivoire. Une espèce endémique, la Pintade à Poitrine Blanche Agelastes meleagrides, est propablement déjà disparue, puisque sa présence ne puisse être enregistrée qu'avant l'exploitation forestière. La différence entre l'avifaune de forêt classée et ses environs était considerable: $70 \%$ des espèces présentes dans la forêt (110 des 159 espèces) n'ont pas été enregistré en dehors.

7. La diversité "alpha" et l'équitabilité des oiseaux capturés aux filets japonais sur une superficie de deux hectares étaient plus basses que dans les forêts primaires de la région de 
Nimba (Côte d'Ivoire) et Gola (Sierra Leone), mais comparable à une autre forêt peu exploités (forêt classée de la Mabi, Côte d'Ivoire).

8. 118 espèces étaient considérées être résidentes dans la zone d'étude de 110 hectare pendant une période de trois mois (Juin à Août 1997). L'extrapolation de cette richesse spécifique trouvée au nombre total pour les 110 hectares était estimée entre 136 et 139. Le même nombre d'espèces, 136, était le nombre total enregistré aux plusieurs méthodes pendant toute l'étude de treize mois.

9. La communauté des oiseaux était dominée par quatre espèces du sous-bois: le Bulbul à Moustaches Jaunes Andropadus latirostris, la Grive Akalat Brune Illadopsis fulvescens, l'Hylia Verte Hylia prasina et le Soui-manga Olivâtre Nectarinia olivacea. La distribution de l'abondance de la communauté était pas différente de la distribution "log-normal" théorétique, mais la proportion des espèces rares $(<0.25$ groupes $/ 100$ ha) semblait être élevée, donc la différence à une distribution "log-series" n'était pas grande. L'équitabilité était haute, mais considérablement plus basse que dans les communautés des forêts primaires à Guyana française.

10. Densités des couples des différentes espèces étaient plus liées à la stratification vertical qu' à la répartition geographique. Dans une comparaison interspecifique, une corrélation négative entre le hauteur de la strate forestière préférée et la densité était constatée. Il n’y avait pas une corrélation entre la grandeur de la répartition géographique et l'abondance. Parmi les espèces de la région Guinée-Congo ainsi que parmi les espèces réparties dans toutes les forêts Africaines aussi bien des membres rares que des membres plus abondants étaient trouvés. Ainsi les espèces limitées à la région de la Haute Guinée que les espèces ubiquites montraient des abondances basses. Mais comparé à l'état d'une forêt primaire, la plupart des espèces Haute Guinéennes et Guinée-Congoliennes avaient des densités plus basses. Seulement peu d'espèces reparties dans toutes les forêts Africaines et aucune espèce ubiquites avaient des densités plus basses que dans la forêt primaire.

11. 63 espèces d'oiseaux étaient enregistrées dans les rondes d'oiseaux multi-specifiques. Les rondes semblaient plus petites en espèces et individus que celles rapportées des forêts matures. Les espèces du sous-bois et des basses strates moyennes étaient plus régulièrement enregistrées que les espèces des strates supérieures.

12. A petite échelle (18,3 ha), la richesse spécifique et la diversité ne différaient pas entre la zone d'éclaircie sélective et la zone de contrôle. A une échelle plus grande ( 32 hectares), la richesse spécifique semblait plus basse dans la zone d'éclaircie sélective. Les courbes des abondances d'espèce n'étaient pas différentes entre les compartiments et ne différaient pas des modèles "log-series" et "log-normal".

13. La composition spécifique changeait remarquablement à une petite échelle (18,3 ha) entre la zone de contrôle, de l'éclaircie sélective, de la plantation et du bas-fond. Les différences étaient les plus grandes entre le contrôle et bas-fonds ou plantation que entre le contrôle et l'éclaircie sélective.

14. Dans comparaisons interspecifiques, les préférences d'habitat étaient au plus expliquées par la répartition géographique. Par contre, le régime alimentaire, la taille ou la stratification verticale ne semblaient pas être liés aux préférences d'habitat. Plusieurs espèces reparties dans toutes les forêts Africaines montraient une préférence pour la zone d'éclaircie sélective. Les abondances les plus grandes des espèces ubiquites étaient trouvées dans la 
plantation forestière. Pour la plupart des pycnonotides, les abondances les plus grandes se montraient dans la zone de contrôle. Les sylviides ne montraient aucune préférence au niveau de la famille.

15. Les oiseaux du sous-bois étaient capturés aux filets aux différentes échelles (2 à 16 hectares) dans une zone de contrôle et une zone perturbée par l'exploitation et par l'éclaircie sélective. La richesse spécifique et la diversité des espèces du sous-bois à l'échelle la plus petite ( 2 à 8 hectare) semblaient être élevées dans la zone de perturbation comparée à la zone de contrôle. A une échelle de 16 hectare, il n'y avait plus une différence. En plus, l'extrapolation de la richesse spécifique (Colwell 1997) indicait une plus grande richesse spécifique pour la zone de contrôle que pour la zone de perturbation. La composition spécifique des oiseaux du sous-bois dans la zone de contrôle et de perturbation se ressemblait (Morisita Horn indexe de 0.80).

16. Une comparaison interspecifique des captures des oiseaux du sous-bois était faite. Pour chaque espèce, la préférence d'habitat était définie comme le pourcentage des captures enregistré dans la zone de contrôle. Il y avait une corrélation entre la préférence d'habitat et la répartition géographique. Les espèces avec une répartition plus limité (Haute Guinéenne ou Guinéenne-Congolienne) montraient une préférence plus grande que les espèces plus répandues (espèces des forêts Africaines, espèces ubiquites). En plus, une corrélation positive était trouvée entre la préférence pour la zone de contrôle et la taille des espèces, particulièrement chez les pycnonotides. En outre, il y avait une corrélation négative entre la hauteur préférée et la préférence pour la zone de contrôle.

17. Pour huit espèces, la fréquence de capture différait entre la zone de perturbation et la zone de contrôle. Tandis que le nombre total des captures ne différait pas entre la zone de perturbation et la zone de contrôle, le nombre d'individus était plus haut dans la zone de perturbation. Dans une espèce, le Bulbul à Moustaches Jaunes Andropadus latirostris, il y avait une différence proportionnelle dans le nombre d'individus capturé et le pourcentage d'individus récapturés entre la zone de perturbation et la zone de contrôle: Alors que le nombre d'individus capturés de cette espèce était plus haut dans la zone de perturbation, le nombre des individus y était plus bas. La situation était l'inverse dans la zone de contrôle où le nombre d'individus du Bulbul à Moustaches Jaunes capturés était comparable ou plus bas que dans la zone de perturbation, tandis que le pourcentage des individus récapturés (bagués pendant la période antérieure) était plus haut. En outre, le poids moyen des individus du Bulbul à Moustaches Jaunes était plus haut dans la zone de contrôle que dans la zone de perturbation. Ceci indique que pour le Bulbul à Moustaches Jaunes, la zone d'amémagement représente une habitat de qualité inférieure. 


\section{References}

Achtziger, R., Nigmann, U. \& H. Zwölfer. 1992. Rarefaction-Methoden und ihre Einsatzmöglichkeiten bei der zooökologischen Zustandsanalyse und Bewertung von Biotopen. Zeitschrift für Ökologie und Naturschutz 1: 89-105.

Allee, W.C. (1926): Measurement of environmental factors in the tropical rain-forest of Panama. Ecology 7: 273-302.

Allen-Wardell, G., Bernhard, P., Bitner, R., Burquez, A., Buchmann, S., Cane, J., Cox, P.A., Dalton, V., Feinsinger, P., Ingram, M., Inouye, D., Jones, C.E., Kennedy, K., Kevan, P., Koopowitz, H., Medellin, R., Medellin-Morales, S., Nabhan, G.P., Pavlik, B., Tepedino, V., Torchio, P. \& Walker, S. (1998): The Potential Consequences of Pollinator Declines on the Conservation of Biodiversity and Stability of Food Crop Yields.- Conservation Biology 12, 8-17.

Allport, G. (1991): The status and conservation of threatened birds in the Upper Guinea forest. Birdlife Conservation International 1: 53-74.

Allport, G.A., Ausden, M., Hayman, P.V., Robertson, P. \& Wood, P. (1989): The Conservation of the birds of the Gola forest, Sierra Leone. International Council for Bird Preservation (Study report 38), Cambridge, UK.

Allport, G.A., Ausden, M.J., Fishpool, L.D.C., Hayman, P.V., Robertson, P.A. \& Wood, P. (1996): Identification of Illadopsises Illadopsis spp. in the Upper Guinea forest. Bull. ABC. 3: 26-30.

Amadon, D. (1973): Birds of the Congo and Amazon Forests: A Comparison. Pp. 267-277 in Tropical forest ecosystems in Africa and South America: A comparative review (Meggers, B.J., Ayensu, E.S. \& Duckworth, W.D., eds.), Smithsonian Institution Press, Washington, D.C.

Bamba, S. (1999): Évaluation des Forêts Classées de l'Est de la Côte d'Ivoire sur la base de l'evolution des populations de quatres espèces d'oiseaux (Période Mars 1994 à Mars 1999) et des données sur la stratification verticale. Master thesis, University of Göttingen, Germany.

Barnes, R.F.W. (1990): Deforestation trends in tropical Africa. Afr. J. Ecol. 28: 161-173.

Basset, Y., Aberlenc, H.-P. \& Delvare, G. (1992): Abundance and stratification of foliage arthropods in a lowland rainforest of Cameroon. Ecological Entomology 17: 310-318.

Basset, Y., Novotny, V., Miller, S.E. \& Springate, N.D. (1998): Assessing the impact of forest disturbance on tropical invertebrates: some comments. J. Appl. Ecol. 35: 461-466. 
Beehler, B. (1981): Ecological structuring of forest bird communities in New Guinea. Monographiae Biologicae 42: 837-861.

Begon, M., Harper, J.L. \& Townsend, C.R. (1986): Ecology. Individuals, Populations, Communities. Blackwell Scientific Publications, Oxford, UK.

Bell, H.L. (1982): A bird community of lowland rain forest in New Guinea. 1. Composition and density of the avifauna. Emu 82: 24-41.

Bierregaard, R.O. \& Stouffer, P.C. (1997): Understorey birds and dynamic habitat mosaics in the Amazonian rainforest. Pp. 138-155 in Tropical Forest Remnants. Ecology, Management and Conservation of Fragmented Communities (Laurance, W.F. \& Bierregaard, R.O., eds.), University of Chicago Press, Chicago.

Bock, C.E. \& Ricklefs, R.E. (1983): Range size and abundance of some North American songbirds: a positive correlation. The American Naturalist 122: 295-299.

Bonnefille, R. \& Letouzey, R. (1976): Fruits fossiles d'Antrocaryon dans la vallée de l'Omo (Ethiopie). Adansonia 16: 65-82.

Bourlière, F. (1989): Mammalian species richness in tropical rainforest. Pp. 153-168 in Vertebrates in complex tropical systems (Harmelin-Vivien, M.L. \& Bourlière, F., eds.), Ecological studies No. 69, Springer, New York.

Bowen-Jones, E. (1998): A review of the commercial bushmeat trade with emphasis on Central/West Africa and the great apes. African Primates (Supplement) 3: S 1 - S 37.

Brooks, T.M. \& Balmford, A. (1996): Atlantic forest extinctions. Nature 380: 115.

Brooks, T.M., Pimm, S.L. \& Oyugi, J.O. (1999): Time lag between deforestation and bird species extinction in tropical forest remnants. Conservation Biology 13: 1140-1150.

Brosset, A. (1969): La vie sociale des oiseaux dans une forêt équatoriale du Gabon. Biol. Gabonica 5: 29-69.

Brosset, A. (1981): Occupation du milieu et structure d'une population du bulbul forestier Andropadus latirostris (Pycnonotidae). L'Oiseau et R.F.O. 51: 115-125.

Brosset, A. (1982): The social life of the African Forest Yellow-whiskered Greenbul Andropadus latirostris. Z. Tierpsychol. 60: 239-255.

Brosset, A. (1990): A long term study of the rain forest birds in M'Passa (Gabon). Pp. 259-274 in Biogeography and ecology of forest bird communities (Keast, A., ed.), SPB Academic Publishing, The Hague, Netherlands. 
Brosset, A. \& Erard, C. (1986): Les oiseaux des régions forestières du Nord-Est du Gabon. Vol I: Écologie et Comportement des Espèces. Société Nationale de Protection de la Nature, Paris, France, 297 pp.

Brown, J.L. (1964): The evolution of diversity in avian territorial systems. Wilson Bull. 76: 160-169.

Brown, J.L. (1969): Territorial behaviour and population regulation in birds. A review and reevaluation. Wilson Bull. 81: 293-329.

Brown, J.H. (1984): On the relationship between abundance and distribution of species. The American Naturalist 124: 255-279.

Brown, L.H., Urban, E.K. \& Newman, K. (1982): The Birds of Africa. Vol I. Academic Press, London.

Carlton, C.E. \& Robison, H.W. (1998): Diversity of litter-dwelling beetles in the Ouachita Highlands of Arkansas, USA (Insecta: Coleoptera). Biodiv. Conserv. 7: 1589-1605.

Caspary, U. (1997): La chasse et la viande de brousse dans la région d'Abengorou, tome 1/2. Unpublished report to SODEFOR/ GTZ, $132 \mathrm{pp}$.

Chao, A. (1984): Non-parametric estimation of the number of classes in a population. Scandinavian Journal of Statistics 11, 265-270.

Chao, A. \& Lee, S.-M. (1992): Estimating the number of classes via sample coverage. Journal of the American Statistical Association 87, 210-217.

Chao, A., Ma, M.-C. \& Yang, M.C.K. (1993): Stopping rules and estimation for recapture debugging with unequal failure rates. Biometrika 80:193-201.

Chappuis, C. (1974a,b; 1975, 1978, 1979, 1985). Supplément Sonore, Alauda Vol. 42 (2, 4) pp. 197-222, pp. 467-500; 43 (4) pp. 427-474; 46(4) pp. 327-355; 47 (3) pp. 195-212; 53 (2) pp. 115-136. Including the disc recordings, No.1-6, 8-10, 12 and 13.

Chatelain, C. (1996): Possibilités d'application de l'imagerie satellitaire à haute resolution pour l'étude des transformations de la végétation en Côte d'Ivoire forestière. Doctoral thesis No. 2868, Université de Genève, 177 pp.

Collar, N.J., Crosby, M.J. \& Stattersfield, A.J. (1994): Birds to Watch 2. The World list of Threatened Birds. Birdlife International, Cambridge. 
Colston, P.R. \& Curry-Lindahl, K. (1986): The birds of Mount Nimba, Liberia. British Museum (Natural History) publication no. 982, London. 129 pp.

Colwell, R. K. (1997): EstimateS: Statistical estimation of species richness and shared species from samples. Version 5. User's Guide and application published at: http://viceroy.eeb.uconn.edu/estimates.

Colwell, R. K., \& Coddington, J. A. (1994): Estimating terrestrial biodiversity through extrapolation. Phil. Trans. Royal Soc. B 345: 101-118.

Colwell, R.K. \& Coddington, J.A. (1995): Estimating terrestrial biodiversity through extrapolation. Pp. 101-118 in Biodiversity measurement and estimation (Hawksworth, D.L., ed.). Chapman \& Hall, London, 140 pp.

Cracraft, J. (1985): Historical biogeography and patterns of differentiation within the South American avifauna: areas of endemism. Pp. 49-84 in Neotropical Ornithology, Ornithological Monographs no. 36 (Buckley, P.A., Foster, M.S., Morton, E.S., Ridgeley, R.S. \& Buckley, F.G., eds.), American Ornithologist's Union Washington.

Crome, F.H. (1997): Researching Tropical Forest Fragmentation: Shall we keep on doing what we're doing? Pp. 485-501 in Tropical Forest Remnants. Ecology, Management, and Conservation of Fragmented Communities (Laurance, W.F. \& Bierregaard, R.O. eds.), University of Chicago Press, Chicago \& London.

Croxall, J.P. (1976): The composition and behaviour of some mixed species bird flocks in Sarawak. Ibis 113: 333-346.

Danielsen, F. (1997): Stable environments and fragile communities: does history determine the resilience of avian rain-forest communities to habitat degradation? Biodiv. Conserv. 6: 423-433.

Demey, R. (in prep.): Babblers. In Birds of West Africa. Helm Identification Guide Series.

Demey, R. \& Fishpool, L.D.C. (1994): The Birds of Yapo Forest, Ivory Coast. Malimbus 16: 100-122.

De Vries, P.J. (1988): Stratification of fruit-feeding nymphalid butterflies in a Costa Rican rainforest. J. Res. Lepid. 26: 98-108.

Dias, P. (1996): Sources and sinks in population biology. TREE 11: 326-330.

Din, N.A. (1991): Resource sharing and niche overlap in some weaver birds of the Genus Ploceus and Malimbus at Ife, Nigeria. Afr. J. Ecol. 29: 43-53. 
Dowsett, R.J. \& Forbes-Watson, A.D. (1993): Checklist of Birds of the Afrotropical and Malagasy Regions. Tauraco Press, Liège.

Dranzoa, C. (1998): The avifauna 23 years after logging in Kibale National Park, Uganda. Biodiv. Conserv. 7: 777-797.

Dueser, R. D. \& Shugart, H. H. (1978) Microhabitats in a forest-floor small mammal fauna. Ecology 59: 89-98.

Elgood, J.H., Heigham, J.B., Moore, A.M., Nason, A.M., Sharland, R.E. \& Skinner, N.J. (1994): The Birds of Nigeria. Checklist 4 (2nd ed.). British Ornithologists' Union, Tring, UK, 305 pp.

Erard, C. (1989): Bird community structure in two rainforests: Africa (Gabon) and South America (French Guyana)- a comparison. Pp. 89-122 in Vertebrates in complex tropical systems. Ecological studies No. 69 (Harmelin-Vivien, M.L. \& Bourlière, F. (eds.), Springer, Berlin.

Fermon, H., Dall'Asta, U. \& Mühlenberg, M. (1997): Baited butterflies (Nymphalidae) as a tool for the development of inexpensive and easily implemented monitoring programs in West-African rainforests. - Abstract, The SEL XIth European Congress of Lepidopterology, Malle, Belgium.

Fermon, H., Waltert, M., Larsen, T.B., Dall'Asta, U., Mühlenberg, M. (in prep.): Effects of forest management on diversity and abundance of fruit feeding nymphalid butterflies in south-eastern Côte d'Ivoire. Journal of Insect Conservation.

Fjeldså, J. (1994): Geographical patterns for relict and young species of birds in Africa and South America and implications for conservation priorities. Biodiv. Conserv. 3: 207-226.

Fjeldså, J. (1995): Geographical patterns of neoendemics and older relict species of Andean forest birds: the significance of ecologically stable areas. Pp. 89-102 in Biodiversity and conservation of Neotropical montane forests (Churchill, S.P. et al., eds.), New York Botanical Garden, New York.

Fjeldså, J. (1997): Are biodiversity "hotspots" correlated with current eco-climatic stability? A pilot study using the NOAA-AVHRR remote sensing data. Biodiv. Cons. 6: 401-422.

Fjeldså, J. \& Lovett, J.C. (1997): Geographical patterns of old and young biota: the significance of specific montane areas as evolutionary centres. Biodiv. Conserv. 6: 325 346.

Fishpool, L.D.C. (ed.) (1997): Important Bird Areas in Africa. IBA Criteria: categories, species lists and population thresholds. BirdLife International, unpublished. 
Fishpool, L.D.C. (1999): Little known African bird: Baumann's Greenbul Phyllastrephus baumanni. Bull. ABC 6: 137.

Fishpool, L.D.C. (ed.) (in prep.): Important Bird Areas in Africa and associated Islands. BirdLife International Conservation Series, BirdLife International, Cambridge UK.

Fishpool, L.D.C., Demey, R., Allport, G. \& Hayman, P.V. (1994a): Notes on the field identification of the bulbuls (Pycnonotidae) of Upper Guinea. Part I: The Genera Criniger, Bleda and Andropadus. Bull ABC 1: 90-95.

Fishpool, L.D.C., Demey, R., Allport, G. \& Hayman, P.V. (1994b): Notes on the field identification of the bulbuls (Pycnonotidae) of Upper Guinea. Part II: Phyllastrephus and remaining genera. Bull $A B C$ 1: 90-95.

Fotso, R.C. (1994): Dynamique des peuplements d'oiseaux dans les series ecologiques de la region de Yaounde (Sud Cameroun). Doctoral thesis, Katholike Universiteit Leuven, Belgium, $141 \mathrm{pp}$.

Francis, I.S., Penford, N., Gartshore, M.E. \& Jaramillo, A. (1992): The White-breasted Guineafowl Agelastes meleagrides in Taï National Park, Côte d'Ivoire. Birdlife Conservation International 2: 25-60.

Fretwell, S.D. \& Lucas, jr., H.L.(1970): On territorial behaviour and other factors influencing habitat distribution in birds. I. Theoretical development. Acta biotheoretica 19: 16-36.

Fry, C.H., Keith, S., \& Urban, E.K. (1988): The birds of Africa. Vol. III. Academic Press, London.

Ganzhorn, J. U., Ganzhorn, A. W., Abraham, J.-P., Andriamanarivo, L., \& Ramananjatavo, A. (1990): The impact of selective logging on forest structure and tenrec populations in western Madagascar. Oecologia 84: 126-133.

Gartshore, M.E., Taylor, P.D. \& Francis, I.S. (1995): Forest Birds in Côte d'Ivoire. A survey of Taï National Park and other forests and forestry plantations, 1989-1991. Birdlife International, Cambridge, UK, 55 pp.

Gatter, W. (1998): Birds of Liberia. Pica Press, Mountfield. 320 pp.

Gerold, G. (1995): Soil differentiation and degradation by agricultural and logging impacts in tropical forests of West Africa. Proceedings Int. Congress on soils of tropical forest ecosystems. Samarinda 2: 88-102. 
Goldblatt, P., Manning, J.C. \& Bernhardt, P. (1999): Evidence of bird pollination in Iridaceae of southern Africa. Adansonia 21: 25-40.

Grimes, L.G. (1987): The Birds of Ghana. Checklist No. 9, British Ornithologists' Union, London, $276 \mathrm{pp}$.

Guillaumet, J.L. (1967): Recherches sur la vegetation et la flora de la region du Bas-Cavally (Côte d'Ivoire). Memoires ORSTOM 20, 249 pp.

Guillaumet, J.L. \& Adjanohoun, E. (1971): La végétation. Pp. 157-268 in Le milieu natural de la Côte d'Ivoire. Memoires ORSTOM 50, Paris, France.

Haffer, J. (1974): Avian speciation in tropical South America. Publications of the Nuttal Ornithological Club No.14. Cambridge, Massachussetts, USA.

Haffer, J. (1997): Alternative models of vertebrate speciation in Amazonia: an overview. Biodiv. Conserv. 6: 451-476.

Hall, J.B. \& Swaine, M.D. (1976): Classification and ecology of closed-canopy forest in Ghana. J. Ecol. 64: 913-951.

Hall, J.B. \& Swaine, M.D. (1981): Distribution and ecology of vascular plants in a tropical rain forest. Forest vegetation in Ghana. Junk Publishers, The Hague, Netherlands, 383 pp.

Hamer, K .C., Hill, J. K., Lace, L. A. and Langan, A. M. (1997) Ecological and biogeographical effects of forest disturbance on tropical butterflies of Sumba, Indonesia. J. Biogeo. 24 (1), 67-75.

Hamilton, A.C. (1981): The Quaternary history of African Forests: its relevance to conservation. Afr. J. Ecol. 19: 1-6.

Hamilton, A.C. (1982): Environmental history of East Africa - a study of the quaternary. Academic Press, London, UK, 328 pp.

Hamilton, A.C. (1988): Guenon evolution and forest history. Pp. 13-34 in A Primate radiation: Evolutionary Biology of the African Guenons (Gautier-Hion, A., Bourlière, F., Gautier, J.-P. \& Kingdon, J., eds.), Cambridge University Press, Cambridge, UK.

Hawthorne, W.D. (1993): Forest regeneration after logging. ODA Forestry Series No. 3, London, $52 \mathrm{pp}$. 
Hawthorne, W.D. \& Abu-Juam, M. (1995): Forest Protection in Ghana. With particular reference to vegetation and plant species. IUCN/ODA/Ghana Forest department, IUCN, Gland, Switzerland, 202 pp.

Herremans, M. (1995): Effects of woodland modification by African elephant Loxodonta africana on bird diversity in northern Botswana. Ecography 18: 440-454.

Hetzel, F. (1998): The nutrient and water cycle in a tropical rain forest and a cocoa plantation in Côte d'Ivoire. $\mathrm{PhD}$ thesis, Universität Göttingen.

Hill, J.K., \& Hamer, K.C. (1998): Using species-abundance models as indicators of habitat disturbance in tropical forests. J. Appl. Ecol. 35: 458-460.

Hofmann, T., Roth, H.H., Ellenberg, H. (1998): Wildtierfleisch als natürliche Ressource der Feuchtwaldgebiete in Westafrika - unter besonderer Berücksichtigung zweier DuckerArten in Elfenbeinküste und Ghana. TÖB-Publication TÖB V/7. GTZ, Eschborn, Germany, $159 \mathrm{pp}$.

Holbech, L.H. (1992): Effects of selective logging on a rainforest bird community in western Ghana. MSc. thesis, University of Copenhagen.

Holbech, L.H. (1996): Faunistic diversity and game production contra human activities in the Ghana high forest zone: with reference to the Western Region. PhD thesis, University of Copenhagen.

Hoppe-Dominik, B. (1999): Analyse du système de Biomonitoring pour l'evaluation des activités du projet au Parc National de Taï. GTZ, Eschborn, 47 pp.

Johns, A.D. (1987): The Use of Primary and Selectively Logged Rainforest by Malaysian Hornbills (Bucerotidae) and Implications for their Conservation. Biological Conservation 40: 179-190.

Johns, A.D. (1992): Vertebrate responses to selective logging: implications for the design of logging systems. Phil. Trans. R. Soc. B 335: 437-442.

Johns, A.G. (1996): Bird Population Persistence in Sabahan Logging Concessions. Biological Conservation 75: 3-10.

Johns, A.G. (1997): Timber production and Biodiversity Conservation in Tropical Rain Forests. Cambridge University Press, Cambridge, UK, 225 pp.

Jullien, M, Thiollay, J.-M. (1998): Multi-species territoriality and dynamics of Neotropical forest understorey bird flocks. Journal of Animal Ecology 67: 227-252. 
Karr, J.R. 1976. Weights of African birds. Bull. B.O.C. 96: 92 - 96.

Karr, J.R. \& James, F.C. (1975): Eco-morphological configurations and convergent evolution in species and communities. Pp. 258-291 in Ecology and evolution of communities (Cody, M.L. \& Diamond, J.M. eds.), Harvard University Press, Cambridge, Massachusetts.

Karr, J.R. (1976): Within- and between-habitat avian diversity in African and Neotropical lowland habitats. Ecological Monographs 46: 457-481.

Karr, J.R. \& R.R. Roth (1971): Vegetation structure and avian diversity in several new world areas. The American Naturalist 105: 423-435.

Kattan, G.H. (1992): Rarity and vulnerability: The birds of the Cordillera Central, Colombia. Conservation Biology 6: 64-70.

Kavanagh, R.P. \& K.L. Bamkin (1995): Distribution of nocturnal forest birds and mammals in relation to the logging mosaic in south-eastern New South Wales, Australia. Biological Conservation 71: 41-53.

Keast, A. (1990): Distribution and origins of forest birds. Pp. 45 - 59 in: Biogeography and ecology of forest bird communities (Keast, A. ed.), SPB Academic Publishing, The Hague, Netherlands.

Keith, S., Urban, E.K. \& Fry, C.H. (1992): The birds of Africa. Vol. IV. Academic Press, London.

Kofron, C.P. \& Chapman, A. (1995): Deforestation and bird species composition in Liberia, West Africa. Tropical Zoology 8: 239-256.

Krebs, C.J. (1989): Ecological Methodology. Harper \& Row Publishers, New York, 654 pp.

Lambert, F.R. (1992): The consequences of selective logging for Bornean lowland forest birds. Phil. Trans. R. Soc. B 335: 443-457.

Larsen, T. B. (1994) The butterflies of Ghana - their implications for conservation and sustainable use. Report to IUCN and Dept. of Game and Wildlife, Ghana.

Larsen, T. B. (1995) Butterfly biodiversity conservation in the Afrotropical region. In Ecology and Conservation of Butterflies (A.S. Pullin ed), pp. 290-303. London: Chapman and Hall.

Larsen, T. B. (1996) Butterflies as indicator species in Africa - Presidential address. Trop. Lepid. News, 3, 1-4. 
Larsen, T. B. (1999) Butterflies of West Africa - origins, natural history, diversity and conservation. CD-ROM with draft of systematic part. T.B. Larsen, Manila, Phillippines.

Lawton, J.H., Bignell, D.E., Bolton, B., Bloemers, G.F., Eggleton, P., Hammond, P.M., Hodda, M., Holt, R.D., Larsen, T.B., Mawsley, N.A., Stork, N.E., Srivastastava, D.S. \& Watt, A.D. (1998): Biodiversity inventories, indicator taxa and effects of habitat modification in tropical forest. Nature 391: 72-76.

Laurance, W.F. \& Bierregaard, R.O. (1997, eds.): Tropical Forest Remnants. Ecology, Management, and Conservation of Fragmented Communities. University of Chicago Press, Chicago \& London, 616 pp.

Lens, L., Nasirwa, O., Nemeth, E. \& Bennun, L. (1996): Response to simulated intrusions by territorial Yellow-whiskered Greenbuls Andropadus latirostris. Ibis 138: 561-563.

Levey, D.J. (1988): Tropical wet forest treefall gaps and distributions of understorey birds and plants. Ecology 69: 1076-1089.

Lock, J.M. (1986): Plant-animal interactions. Pp. 13-34 in Plant Ecology in West Africa. Systems and Processes (Lawson, G.W., ed.), John Wiley \& Sons, Chichester.

-omnicki, A. (1978): Individual differences between animals and the natural regulation of their numbers. J. Animal Ecol. 47: 461-475.

Louette, M. (1983): Bird species numbers in Cameroon vegetation districts. Malimbus 5: 4549.

Louette, M. (1999): Composition of the West African lowland avifauna. In: Proceedings $22^{\text {nd }}$ International Ornithological Congreß, Durban (Adams, N. \& Slotow, R., eds.), University of Natal, South Africa.

Louette, M., Bijnens, L., Upoki Agenong'a, D. \& Fotso, R.C. (1995): The utility of birds as bioindicators: case studies in equatorial Africa. Belg. J. Zool. 125: 157-165.

MacArthur, R.H. (1955): Fluctuations of animal populations and a measure of community stability. Ecology 36: 533-536.

MacArthur, R.H. \& Wilson, E.O. (1967): The theory of island biogeography. Princeton University Press, Princeton, New Jersey, 203 pp.

Mackworth-Praed, C.W. \& Grant, C.H.B. (1970, 1973): African Handbook of Birds. Series III: Vols. I and II Birds of West Central and Western Africa. Longman, London. 671 and $818 \mathrm{pp}$. 
Magurran, A.E. (1988): Ecological Diversity and its Measurement. Princeton University Press, Princeton, New Jersey, USA, 179 pp.

Marsden, S.J. (1998): Changes in bird abundance following selective logging on Seram, Indonesia. Conservation Biology 12: 605-611.

Martin, C. (1989): Die Regenwälder Westafrikas. Ökologie, Bedrohung und Schutz. Birkhäuser, Basel, Switzerland, 235 pp.

Mattes, H. \& Gatter, W. (1989): Jahresperiodik und Biometrie von Andropadus latirostris Strickland (Aves: Pycnonotidae) in Liberia. Stuttgarter Beitr. Naturk. Ser. A 429: 1-10.

Mawdsley, N. (1996): The theory and practice of estimating regional species richness from local samples. Pp. 193-213 in Tropical Rainforest research - Current issues. Proceedings of the Conference held in Bandar Seri Begawan, April 1993 (Edwards, W.E., Booth, S.C. \& Choy, S.C., eds.). Kluwer Academic Publishers, London.

May, R.M. (1972): Will a large complex system be stable? Nature 238: 413-414.

McGraw, W.S., Monah, I.T. \& Abedi-Lartey, M. (1998): Survey of endangered primates in the forest reserves of eastern Côte d'Ivoire. African Primates 3: 22-25.

Michler, H. (1994): Bodenqualität und Nähstoffumsatz im Forêt Classée de la Bossematié. Ein Vergleich von Regenwald, landwirtschaftlicher Nutzfläche und ChromolaenaBrache. Diploma thesis, Universität Göttingen.

Moreau, R.E. (1966): The bird faunas of Africa and its islands. Academic Press, London, 424 pp.

Morel, G.J. \& Tye, A. (1995): Guidelines for avifaunal papers in Malimbus. Malimbus 17: 3537.

Mueller-Dombois, D. \& Ellenberg, H. (sen.) (1974): Aims and methods of vegetation ecology. John Wiley \& Sons, New York, 547 pp.

Murphy, D. D. and Wilcox, B. A. (1986) Butterfly diversity in natural habitat fragments: A test of the validity of vertebrate-based management. In Wildlife 2000: Modelling habitat relationships of terrestrial vertebrates (Verner, J., Morrison, M. L. \& Ralph, C. J., eds.), University of Wisconsin Press, Wisconsin.

Mühlenberg, M. (1993): Freilandökologie. $3^{\text {rd }}$ edition. Quelle \& Meyer, Heidelberg, Germany, $511 \mathrm{pp}$. 
Mühlenberg, M., Leipold, H.J., Mader, J. \& Steinhauer, B. (1977): Island ecology of arthropods. II Niches and relative abundances of Seychelles ants (Formicidae) in different habitats. Oecologia 29: 135-144.

Mühlenberg, M., Slowik, J., Wöll, H., Waitkuwait, W.E. (1995): Strategies for restoration of tropical forests that incorporate wildlife protection: an example from the Ivory Coast, West Africa. Pp. 413-417 in Integrating people and wildlife for a sustainable future. Proc. $1^{\text {st }}$ International Wildlife Managemenet Congress (Bissonnette, J.A. \& Krausman, P.R., eds.), The Wildlife Society, Bethesda, Maryland.

Mühlenberg, M., Slowik, J., Waltert, M., Fermon, H., Singo, B. \& Waitkuwait, W.E. (1997): Présentation des données du biomonitoring dans les forêts classées de l'est de la Côte d'Ivoire. Unpubl. report on population developments of monitor species from four Forêts Classées to SODEFOR/GTZ, Zentrum für Naturschutz, Universität Göttingen, Germany.

Mühlenberg, M., Slowik, J., Waltert, M., Fermon, H., Bamba, S. \& Waitkuwait, W.E. (1999): Biomonitoring in Tropenwäldern. Ein Beitrag zur Bewertung von Sustainable Use. Göttinger Beiträge zur Land- und Forstwirtschaft in den Tropen und Subtropen 133: $220-225$.

Mühlenberg, M. \& Waltert, M. (2000): Der Einfluß des Verhaltens von Wirbeltieren auf die Anwendung von Monitoringmethoden. Beispiele aus Westafrika. In Internationales Symposium Naturschutz und Verhalten, Göttingen 1999 (Gottschalk, E., Mühlenberg, M., Barkow, A. \& Settele, J., eds.), UFZ-Berichte, Leipzig (in press.).

Nett, D. (1999): Ansätze zur Schätzung der Siedlungsdichte von Maxwellduckern (Cephalophus maxwelli) in degradierten Sekundärwäldern Westafrikas. Territoriumsgrößen, Habitatpräferenzen und Aktivitätsrhythmen. Diploma thesis, Universität Hamburg.

Nummelin, M. (1998): Log-normal distribution of species-abundances is not a universal indicator of rainforest disturbance. J. Appl. Ecol. 35: 454-456.

O'Brian, T.G. \& M.F. Kinnaird (1996): Changing populations of birds and mammals in North Sulawesi. Oryx 30: 150-156.

Owiunji, I. \& Plumptre, A.J. (1998): Bird communities in logged and unlogged compartments in Budingo Forest, Uganda. Forest Ecology and Management 108: 115 - 126.

Parren, M.P.E., de Graaf, N.R. (1995): The quest for natural forest management in Ghana, Côte d'Ivoire and Liberia. Tropenbos Series 13, Wageningen, 199 pp. 
Payne, J. (1995): Links between vertebrates and the conservation of Southeast Asian rainforest. Pp. 54-65 in Ecology, Conservation, and Management of Southeast Asian rainforests (Primack, R.B. \& Lovejoy, T.E., eds.). Yale University Press, New Haven, London.

Pearson, D.L. (1971): Vertical Stratification of birds in a tropical dry forest. Condor 73: 4655.

Pearson, D.L. (1975): The relation of foliage complexity to ecological diversity of three Amazonian bird communities. The Condor 77: 453-466.

Pomeroy, D. \& Service, M.W. (1986); Tropical Ecology. Longman, London, UK, 234 pp.

Pulliam, H.R. (1988): Sources, sinks and population regulation. The American Naturalist 132: 652-661.

Pulliam, H.R., Dunning, J.B. \& J. Liu (1992): Population dynamics in complex landscapes. Ecological Applications 2: 165-177.

Richards, P.W. (1952): The Tropical Rain Forest. Cambridge University Press, Cambridge, UK.

Robertson, A.W., Kelly, D., Ladley, J.J. \& Sparrow, A.D. (1999): Effects of pollinator loss on endemic New Zealand mistletoes (Loranthaceae). Conservation Biology 13: 499-508.

Robinson, S.C., Terborgh, J. \& Munn, C. (1990): Lowland tropical forest bird communities of a site in Western Amazonia. Pp. 229-258 in Biogeography and ecology of forest bird communities (Keast, A., ed.), SPB Academic Publishing, The Hague, Netherlands.

Robinson, S.K. \& Terborgh, J. (1995): Interspecific aggression and habitat selection by Amazonian birds. J. Animal Ecol. 64: 1-11.

Rompay, R.S.A.R. van (1993): Forest gradients in West Africa. A spatial analysis. Doctoral thesis, Department of Forestry, Agricultural University, Wageningen, Netherlands, 142 pp.

Rose, A. (1998): Growing commerce in bushmeat destroys great apes and threatens humanity. African Primates 3: 6 - 12.

Roy, M.S. (1997): Recent diversification in African greenbuls (Pycnonotidae: Andropadus) supports a montane speciation model. Proceedings of the Royal Society of London Series B Biological Sciences 264: 1337-1344. 
Ruggiero, R.G. \& Eves, H.E. (1998): Bird-mammal associations in forest openings of northern Congo (Brazaville). Afr. J. Ecol. 36: 183-193.

Sayer, J.A., Harcourt, C.S. \& Collins, N.M. (1992): The conservation atlas of tropical forests. Africa. WCMC-IUCN, New York, 299 pp.

Sazima, M. \& Sazima, I. (1999): The perching bird Coereba flaveola as a co-pollinator of bromeliad flowers in south-eastern Brazil. Canadian Journal of Zoology 77: 47-51.

Schemske, D.W. \& Brokaw, N. (1981): Treefalls and the distribution of understorey birds in a tropical forest. Ecology 62: 938-945.

Serle, W., Morel, G. \& Hartwig, W. (1977): A field guide to the birds of West Africa. Collins, London, $351 \mathrm{pp}$.

Schemske, D.W. \& N. Brokaw (1981): Treefalls and the distribution of understorey birds in tropical forest. Ecology 62: 938-945.

Schulze, C.H. (1995): Die Tagfalterzönose eines südostasiatischen Regenwaldes. Muster und Mechanismen der Stratifikation. Diploma thesis, University of Würzburg, Germany.

Shinozaki, K. 1963. Note on the species-area curve. Proc. of the 1th Ann. Meet. Ecol. Soc. Japan 5. Tokyo.

SODEFOR (1994): Plan d'Amenagement de la Forêt Classée de Bossematié. SODEFOR / GTZ / KFW (unpubl.), Abengourou, Côte d'Ivoire, 86 pp.

SODEFOR (1996): Forêts Classées de Côte d'Ivoire. Map at scale 1:800,000. SODEFOR, Abidjan, Côte d'Ivoire.

Sowunmi, M.A. (1986): Change of vegetation with time. Pp. 273-307 in Plant ecology in West Africa. Systems and processes (Lawson, G.W., ed.), John Wiley \& Sons, Chichester, UK.

States, J.B. (1976): Local adaptations in chipmunk (Eutamias amoenas) populations and evolutionary potential at species borders. Ecol. Monogr. 46: 221-256.

Statsoft (1995): Statistica 5.1. Vol. I. Tulsa, Oklahoma.

Stattersfield, A.J., Crosby, N.J., Long, A.G. \& Wege, D.C. (1998) Endemic Bird Areas of the World. Priorities for Bird Conservation. Birdlife International, Cambridge, UK, 846 pp.

Stenseth, N.C. (1979): Where have all the species gone? On the nature of extinction and the Red Queen Hypothesis. Oikos 33: 196-227. 
Stiles, F.G. \& Wolf, L.L. (1970): Hummingbird territoriality at a tropical flowering tree. Auk 87: 467-491.

Struhsaker, T.T. (1997): Ecology of an African Rain Forest. Logging in Kibale and the conflict between conservation and exploitation. University of Florida Press, Gainesville, USA, 434 pp.

Sutton, S.L. \& Hudson, P.J. (1980): The vertical distribution of small flying insects in the lowland rainforest of Zaire. Zoological Journal of the Linnean Society 68: 111-123.

Swaine, M.D. \& Hall, J.B. (1986): Forest structure and dynamics. Pp. 273-307 in Plant ecology in West Africa. Patterns and Processes (Lawson, G.W., ed.), John Wiley \& Sons, Chichester.

Taylor, I.R. \& MacDonald (1978): The Birds of Bia National Park, Ghana. Bull. Nigerian Orn. Soc. 14: 36-41.

Terborgh, J. (1980): Vertical Organisation of a Neotropical Forest Bird Community. Symposium on Habitat Utilisation. Proceedings of the 17th International Ornithological Congress.

Terborgh, J., Robinson, S.K., Parker, T.A.III., Munn, C. \& Pierpont, N. (1990): Structure and organisation of an Amazonian forest bird community. Ecological Monographs 60: 213238.

Thiollay, J.M. (1985a): The West African forest avifauna: a review. Pp. 171-186 in: Conservation of Tropical Forest Birds (Diamond, A.W. \& Lovejoy, T.E., eds.), ICBP Tech. Pub. No. 4, Cambridge, UK.

Thiollay, J.M. (1985b): The birds of Ivory Coast: status and distribution. Malimbus 7: 1-59.

Thiollay, J.M. (1992): Influence of Selective Logging on Bird Species Diversity in a Guianan Rain Forest. Conservation Biology 6: 47-63.

Thiollay, J.M. (1994a): Disturbance, selective logging and bird diversity: a Neotropical forest study. Biodiv. Conserv. 6: 1155-1173.

Thiollay, J.-M. (1994b): Structure, density and rarity in an Amazonian rainforest bird community. J. Tropical Ecol. 40: 449-481.

Urban, E.K., Fry, C.H. \& Keith, S. (1986): The birds of Africa. Vol. II. Academic Press, London. 
Urban, E.K., Fry, C.H. \& Keith, S. (1997): The birds of Africa. Vol. V. Academic Press, London.

Van Horne, B. (1982): Niches of adult and juvenile deer mice (Peromyscus maniculatus) in serial stages of coniferous forest. Ecology 63: 92-103.

Waide, R.B., Willig, M.R., Steiner, C.F., Mittelbach, G., Gough, L., Dodson, S.I., Juday, G.P. \& Parmenter, R. (1999): The relationship between productivity and species richness. Ann. Rev. Ecol. Syst. 30: 257-300.

Waitkuwait, W.E. (1992) Restauration d'un écosystème forestier: contribution à l'amenagement de la faune. P. 203-214 in Compte rendu séminaire sur l'aménagement integré des forêts denses humides et des zones agricoles périphériques, Abidjan, 1991 (Vooren, A.P., Schork,W.A. \& Spijkerman, A.J.C., eds.). Tropenbos Series 1, Wageningen.

Waltert, M. (1996): Unterholzstruktur und Habitatpräferenzen von Unterholzvögeln im Forêt Classée de la Bossematié - Erste Ergebnisse aus dem Zeitraum Dezember 1995 - März 1996. Report to GTZ, Eschborn, SODEFOR, Abengourou, 39 pp.

Waltert, M. (1999): Development of Biomonitoring in Concession Areas (MPL and CAFECO) in the Korup Project Area, Cameroon, October 1999. Report to GTZ, Eschborn, ECO, Oberaula, 36 pp.

Waltert, M. (2000): Forest management and the distribution of understorey birds in the Bossematié Forest, eastern Ivory Coast. Ostrich Suppl. (in press).

Waltert, M. \& Mühlenberg, M. (1999): Notes on the birds of the Noyau Central, Forêt Classée de la Lama, Republic of Benin. Malimbus 21: 82-92.

Waltert, M. \& Mühlenberg, M. (2000): Zur Beziehung zwischen Abundanz und Habitatqualität: Fangraten territorialer Gelbbartbülbüls Andropadus latirostris. In Internationales Symposium Naturschutz und Verhalten, Göttingen 1999 (Gottschalk, E., Mühlenberg, M., Barkow, A. \& Settele, J., eds.), UFZ-Berichte, Leipzig (in press).

Waltert, M., Yaokokoré-Beibro, K.H., Mühlenberg, M. \& Waitkuwait, W.E. (1999): Preliminary check-list of the birds of the Bossematié area, Ivory Coast. Malimbus 21: 93-109.

Watt, A.D. (1998): Measuring disturbance in tropical forests: a critique of the use of speciesabundance models and indicator measures in general. J. Appl. Ecol. 35: 467-469.

White, F. (1979): The Guinea-Conglian Region and its relationships to other phytochoria. Bull. Jard. Bot. Nat. Belg. 49: 11-55. 
Whitney, K.D. \& Smith, T.B. (1998): Habitat use and resource tracking by African Ceratogymna hornbills: implications for seed dispersal and forest conservation. Animal Conservation 1: 107-117.

Williamson, P.G. (1985): Evidence for an early Plio-Pleistocene rainforest expansion in East Africa. Nature 315: 487-489.

Winker, K., Rappole, J.H. \& M.A. Ramos. 1995. The use of movement data as an assay of habitat quality. Oecologia 101: 211-216.

Wolf, L.L. \& Hainsworth, F.R. (1971): Time and energy budgets of territorial hummingbirds. Ecology 52: 980-988.

Wöll, H.J. (1991): Plan d'aménagement élaboré pour quelques parcelles d'une série de production-regeneration naturelle dominante - de la Forêt Classée de la Bossematié $(F C B)$. Abidjan, Côte d'Ivoire, SODEFOR; Eschborn, Germany, GTZ, 30 pp.

Wöll, H.J. (1992): Le projet "Rehabilitation de la Forêt Classée de Bossematié", Côte d'Ivoire, Region d'Abengourou. Pp. 163-179 in Compte rendu séminaire sur l'aménagement intégré des forêts denses humides et des zones agricoles périphériques. Tropenbos Series 1 (A.P. Vooren, W. Schork, W.A: Blokhuis and A.J.C. Spijkerman, eds), Tropenbos Foundation, Wageningen, Netherlands.

WWF (2000): Forest maps: Côte d'Ivoire. published at: http://www.panda.org/ forests4life/forestmaps/frame_mainciv.htm

Yahner, R.H. (1988): Changes in wildlife communities near edges. Conservation Biology 2: 333-9. 
Appendices 


\section{Appendix A Systematic list of the birds of the Bossematié area}

One species, Sylvietta denti, completed the list of Waltert et al. (1999). The nomenclature follows Brown et al. (1982), Urban et al. (1986), Fry et al. (1988), Keith et al.( 1992), Urban et al. (1997) and Dowsett \& Forbes-Watson (1993), and the assessment of abundance, Morel \& Tye (1995):

$\begin{array}{ll}\text { Very abundant (VA) } & \begin{array}{l}>100 \text { may be seen or heard in suitable } \\ \text { habitat per day } \\ \text { Abundant (A) }\end{array} \\ \text { Common (C) } & \begin{array}{l}\text { suitable habitat per day } \\ 1-10 \text { may be seen or heard in suitable } \\ \text { habitat per day } \\ \text { often seen but not every day }\end{array} \\ \text { Frequent (F) } & \begin{array}{l}\text { several records per year } \\ \text { one record per several years (resident } \\ \text { Species) }\end{array} \\ \text { Rare (R) } & \begin{array}{l}\text { one record per several years (non- } \\ \text { residents) }\end{array}\end{array}$

\section{Other abbreviations}

BF: recorded inside the Bossematie forest

NF: recorded in areas surrounding the Bossematié forest

\section{Phalacrocoracidae}

Phalacrocorax africanus Long-tailed Cormorant. Four, NF, 18 Jun 1995

\section{Anhingidae}

Anhinga rufa African Darter. One, NF, Feb 1996

\section{Ardeidae}

Ardeola ralloides Squacco Heron. Five, NF, 18 Jun 1995, One, NF, 14 Mar 1996.

Bubulcus ibis Cattle Egret. C, NF.

Butorides striatus Green Heron. F, NF.

Egretta garzetta Little Egret. U, NF.

Egretta intermedia Yellow-billed Egret. F, NF.

Ardea purpurea Purple Heron. R, NF

Ardea cinerea Grey Heron. F, NF.

\section{Scopidae}

Scopus umbretta Hamerkop. One, NF, 9 Mar 1996.

\section{Acciptridae}

Pandion haliaetus Osprey. One, NF, 25 Dec 1995.

Aviceda cuculoides African Cuckoo Falcon. F, BF.

Pernis apivorus Honey Buzzard. One, NF, Mar 1996.

Elanus caeruleus Black-shouldered Kite. R, NF, 18 Jun 1995.

Milvus migrans Black Kite. C, NF.

Gypohierax angolensis Palm-nut Vulture. C, NF; C, BF.

Necrosyrtes monachus Hooded Vulture. C, NF.

Circaetus cinerascens Smaller Banded Snake Eagle. One, NF, 2 Jun 1995; One, BF, 6 Feb 1996.

Polyboroides typus African Harrier Hawk. C, NF; C, BF.

Accipiter tachiro African Goshawk. C, NF, C, BF.

Accipiter badius Shikra. One, NF, 10 Apr 1995. 
Accipiter erythropus Red-thighed Sparrowhawk. F, BF.

Accipiter melanoleucos Black Sparrowhawk. U, BF.

Urotriorchis macrourus Long-tailed Hawk. F, BF.

Aquila wahlbergi Wahlberg's Eagle. One, BF, 7 Feb 1996.

Stephanoaetus coronatus Crowned Eagle. F, BF.

Hieraaetus ayresii Ayres's Hawk Eagle. One, BF, 19 Aug 1997.

Falco ardosiaceus Grey Kestrel. One, NF, 7 Feb 1996.

Falco biarmicus Lanner Falcon. C, NF; Two juvs, 21. Mar 1996.

Falco tinnunculus Common Kestrel. One, NF, 10 Apr 1995.

\section{Phasianidae}

Guttera pucherani Crested Guineafowl. C, BF.

Francolinus lathami Latham's Forest Francolin. C, BF.

Francolinus ahantensis Ahanta Francolin. C, BF; C, NF.

Francolinus bicalcaratus Double-spurred Francolin. U, BF; F, NF.

\section{Rallidae}

Himantornis haematopus Nkulengu Rail. F, BF.

Sarothrura pulchra White-spotted Flufftail. C, BF; F, NF.

Amaurornis flavirostris Black Crake. C, NF.

Crex egregia African Crake. Two, NF, 2 Aug 1997.

Jacanidae

Actophilornis africana African Jacana. C, NF.

\section{Glareolidae}

Glareola nuchalis Rock Pratincole. F, NF.

\section{Charadriidae}

Tringa ochropus Green Sandpiper. Two, NF, 25 Dec 1995.

Tringa glareola Wood Sandpiper. One, NF, 14 Mar 1996.

Actitis hypoleucos Common Sandpiper. Two, NF, 25 Dec 1995 and 16 Mar 1996.

\section{Columbidae}

Treron calva African Green Pigeon. A, BF; A, NF.

Turtur brehmeri Blue-headed Wood Dove. F, BF.

Turtur tympanistria Tambourine Dove. C, BF; F, NF.

Turtur afer Blue-spotted Wood Dove. F, BF; C, NF.

Oena capensis Namaqua Dove. One, NF, Feb 1996.

Columba iriditorques Western Bronze-naped Pigeon. C, BF.

Columba unicincta Afep Pigeon. F, BF.

Streptopelia semitorquata Red-eyed Dove. C, BF; C, NF.

Streptopelia senegalensis Laughing Dove. C, NF.

\section{Psittacidae}

Psittacus erithacus erithacus Grey Parrot. F, BF.

Poicephalus gulielmi Red-fronted Parrot. C, BF, with flocks up to 15. One sighting, NF.

Poicephalus senegalus Senegal Parrot. One, NF, 8 Jun 1997.

\section{Musophagidae}

Corythaeola cristata Great Blue Turaco. C, BF.

Tauraco macrorhynchus Yellow-billed Turaco. C, BF; R, NF.

Crinifer piscator Western Grey Plantain-eater. F, NF.

\section{Cuculidae}

Oxylophus levaillantii African Striped Cuckoo. One, NF, 7 Feb 1996.

Cuculus solitarius Red-chested Cuckoo. F, BF.

Cuculus clamosus Black Cuckoo. F, BF.

Cercococcyx mechowi Dusky Long-tailed Cuckoo. One, BF, 13 May 1995. 
Cercococcyx olivinus Olive Long-tailed Cuckoo. F, BF.

Chrysococcyx cupreus African Emerald Cuckoo. C, BF; F, NF.

Chrysococcyx klaas Klaas's Cuckoo. C, BF; C, NF.

Chrysococcyx caprius Diederik Cuckoo. C, NF.

Ceuthmochares aereus Yellowbill. F, BF.

Centropus leucogaster Black-throated Coucal. C, BF; U, NF.

Centropus senegalensis Senegal Coucal. F, BF; C, NF.

\section{Tytonidae}

Tyto alba Barn Owl. C, NF.

\section{Strigidae}

Bubo poensis Fraser's Eagle Owl. A captive, Abengourou, 7 Jun 1997. Probably present, BF.

Glaucidium tephronotum Red-chested Owlet. Tape-recorded song, 2 May 1995.

Strix woodfordii African Wood Owl. C, BF; F, NF. An imm., 7. Jun 1997.

Otus icterorhynchus. One, BF, 21 Jun 1997.

Asio capensis Marsh Owl. One Abengourou, 8 June 1997.

\section{Caprimulgidae}

Caprimulgus inornatus Plain Nightjar. One, NF, 18 Jan 1996.

Macrodipteryx longipennis Standard-winged Nightjar. U, NF.

Apodidae

Telacanthura melanopygia Black Spinetail. Four, BF, 16 Jul 1997.

Telacanthura ussheri Mottled Spinetail. Ten, BF, 14 Jun 1997.

Neafrapus cassini Cassin's Spinetail. Two, NF, 12 Jun 1997.

Cypsiurus parvus African Palm Swift. C, NF.

Apus pallidus Pallid Swift. Fifteen, NF, 14 Mar 1996.

Apus affinis Little Swift. C, NF.

Trogonidae

Apaloderma narina Narina's Trogon. F, BF.

Alcedinidae

Halcyon badia Chocolate-backed Kingfisher. F, BF.

Halcyon malimbica Blue-breasted Kingfisher. One, BF, 17 Jun 1995.

Halcyon senegalensis Woodland Kingfisher. C, BF; C, NF.

Ceyx lecontei African Dwarf Kingfisher. One, BF, 12 Sep 1996.

Ceyx picta African Pygmy Kingfisher. F, NF.

Corythornis cristata Malachite Kingfisher. One, NF, 2 May 1995.

Alcedo quadribrachys Shining-blue Kingfisher. One, NF, 18 Jun 1995.

\section{Meropidae}

Merops muelleri Blue-headed Bee-eater. Three observations, BF

Merops gularis Black Bee-eater. F, BF; U, NF.

Merops pusillus Little Bee-eater. F, NF.

Merops albicollis Wite-throated Bee-eater. F, NF.

\section{Coracidae}

Eurystomus gularis Blue-throated Roller. C, BF.

\section{Phoeniculidae}

Phoeniculus castaneiceps Forest Wood-Hoopoe. F, BF.

Phoeniculus bollei White-headed Wood-Hoopoe. F, BF.

\section{Bucerotidae}

Tockus albocristatus White-crested Hornbill. C, BF; U, NF.

Tockus hartlaubi Black Dwarf Hornbill. F, BF.

Tockus camurus Red-billed Dwarf Hornbill. F, BF.

Tockus fasciatus African Pied Hornbill. A, BF; A, NF. 
Ceratogymna fistulator Piping Hornbill. F, BF; U, NF.

Ceratogymna subcylindricus Black-and-white-casqued Hornbill. Two observations, BF. Ceratogymna cylindricus Brown-cheeked Hornbill. F, BF.

Ceratogymna atrata Black-casqued Wattled Hornbill. Three observations, BF.

Ceratogymna elata Yellow-casqued Wattled Hornbill. F, BF.

\section{Capitonidae}

Gymnobucco peli Bristle-nosed Barbet. C, BF; F, NF.

Gymnobucco calvus Naked-faced Barbet. F, BF; C, NF.

Pogoniulus scolopaceus Speckled Tinkerbird. C, BF; C, NF.

Pogoniulus atroflavus Red-rumped Tinkerbird. F, BF.

Pogoniulus subsulphureus Yellow-throated Tinkerbird. C, BF; F, NF.

Pogoniulus bilineatus Yellow-rumped Tinkerbird. F, BF; F, NF.

Tricholaema hirsuta Hairy-breasted Barbet. C, BF; U, NF.

Lybius vieilloti Vieillot's Barbet. U, NF.

Trachyphonus purpuratus Yellow-billed Barbet. C, BF.

\section{Indicatoridae}

Indicator exilis Least Honeyguide. One mist-netted, BF, 21 Feb 1996.

Indicator conirostris Thick-billed Honeyguide. Recorded once, BF, 11 Aug 1997.

\section{Picidae}

Campethera nivosa Buff-spotted Woodpecker. C, BF.

Dendropicos gabonensis Gabon Woodpecker. F, BF.

Dendropicos pyrrhogaster Fire-bellied Woodpecker. C, BF.

\section{Eurylaimidae}

Smithornis rufolateralis Rufous-sided Broadbill. F, BF.

\section{Pittidae}

Pitta angolensis African Pitta. One record of a displaying individual, BF, 27 Dec 1995.

\section{Hirundinidae}

Hirundo abyssinica Lesser Striped Swallow. A, NF.

Hirundo nigrita White-throated Blue Swallow. U, NF.

Hirundo daurica Red-rumped Swallow. Two, NF, 21 Jun 1997.

Hirundo aethiopica Ethiopian Swallow. C in villages between April and October.

Hirundo rustica Barn Swallow. F, BF; F, NF.

Hirundo semirufa Rufous-chested Swallow. C, NF.

\section{Motacillidae}

Motacilla flava thunbergi Yellow Wagtail. One, NF, 14 Mar 1996.

Motacilla aguimp African Pied Wagtail. F, NF.

Anthus leucophrys Plain-backed Pipit. U, NF.

\section{Campephagidae}

Coracina pectoralis White-breasted Cukoo-Shrike. Two, NF, 0 Jun 1995.

Coracina azurea Blue Cuckoo-Shrike. F, BF.

\section{Pycnonotidae}

Andropadus virens Little Greenbul. A, BF; A; NF.

Andropadus gracilis Lttle Grey Greenbul. F, BF.

Andropadus ansorgei Ansorge's Greenbul. F, BF.

Andropadus curvirostris Plain Greenbul. C, BF.

Andropadus gracilirostris Slender-billed Greenbul. C, BF.

Andropadus latirostris Yellow-whiskered Greenbul. A, BF; F, NF.

Calyptocichla serina Golden Greenbul. U, BF.

Baeopogon indicator Honeyguide Greenbul. C, BF.

Ixonotus guttatus Spotted Greenbul. U, BF. 
Chlorocichla simplex Simple Greenbul. F, NF.

Thescelocichla leucopleura Swamp Palm Bulbul. F, BF; F, NF.

Phyllastrephus icterinus Icterine Greenbul. U, BF.

Phyllastrephus albigularis White-throated Greenbul. C, BF; U, NF.

Bleda syndactyla Red-tailed Bristlebill. C, BF.

Bleda eximia Green-tailed Bristlebill. F, BF. Seven mist-netted.

Bleda canicapilla Grey-headed Bristlebill. A, BF; U, NF.

Criniger barbatus Western bearded Greenbul. F, BF.

Criniger calurus Red-tailed Greenbul. C, BF.

Pycnonotus barbatus Common Bulbul. C, BF; A, NF.

Turdidae

Stiphrornis erythrothorax Forest Robin. F, BF.

Alethe diademata Fire-crested Alethe. $\mathrm{C}, \mathrm{BF}$.

Neocossyphus poensis White-tailed Ant-Thrush. F, BF.

Neocossyphus finschii Finsch's Flycatcher-Thrush. F, BF.

\section{Sylviidae}

Cisticola lateralis Whistling Cisticola. A, NF.

Prinia subflava Tawny-flanked Prinia. F, NF.

Apalis sharpii Sharpe's Apalis. C, BF.

Camaroptera brachyura Bleating Warbler. U, BF; C, NF.

Camaroptera superciliaris Yellow-browed Camaroptera. C, BF; F, NF.

Camaroptera chloronata Olive-green Camaroptera. C, BF.

Macrosphenus kempi Kemp's Longbill. C, BF.

Macrosphenus concolor Grey Longbill. C, BF.

Eremomela badiceps Rufous-crowned Eremomela. F, BF.

Sylvietta denti Lemon-bellied Crombec. Recorded once, BF.

Sylvietta virens Green Crombec. C, BF; C, NF.

Hyliota violacea Violet-backed Hyliota. U, BF.

Hylia prasina Green Hylia. C, BF; F, NF.

\section{Muscicapidae}

Fraseria ocreata Fraser's Forest Flycatcher. C, BF.

Muscicapa striata Spotted Flycatcher. One, NF, 9 Mar 1996.

Muscicapa caerulescens Ashy Flycatcher. Observed twice, BF, 8 and 20 Aug 1997.

Muscicapa epulata Little Grey Flycatcher. Only two observations, but eight mist-netted, BF.

Muscicapa ussheri Ussher's Flycatcher. F, BF; F, NF.

\section{Monarchidae}

Erythrocercus mccallii Chestnut-capped Flycatcher. C, BF.

Trochocercus nitens Blue-headed Crested Flycatcher. C, BF.

Terpsiphone rufiventer Red-bellied Paradise-Flycatcher. C, BF; F, NF.

\section{Platysteiridae}

Bias musicus Black-and-white Flycatcher. One, NF, 10 Jun 1995.

Dyaphorophyia castanea Chestnut Wattle-eye. C, BF.

Dyaphorophyia blissetti Red-cheeked Wattle-eye. A pair mist-netted, NF, 3 May 1995.

Timaliidae

Illadopsis fulvescens Brown Illadopsis. C, BF.

Illadopsis rufipennis Pale-breasted Illadopsis. F, BF.

Illadopsis cleaveri Blackcap Illadopsis. F, BF.

Illadopsis rufescens Rufous-winged Illadopsis.

\section{Remizidae}

Pholidornis rushiae Tit-hylia. Five, NF, 10 Jun 1995. 


\section{Paridae}

Parus funereus Dusky Tit. Five records, BF

\section{Nectariniidae}

Anthreptes fraseri Fraser's Sunbird. C, BF.

Anthreptes rectirostris Yellow-chinned Sunbird. One, BF, 9 Aug 1997.

Anthreptes collaris Collared Sunbird. C, BF.

Nectarinia seimundi Little Green Sunbird. U, BF.

Nectarinia olivacea Olive Sunbird. A, BF; F, NF.

Nectarinia adelberti Buff-throated Sunbird. F, BF.

Nectarinia senegalensis Scarlet-breasted Sunbird. One, NF, 20 Jul 1997.

Nectarinia coccinigaster Splendid Sunbird. U, NF.

Nectarinia venusta Yellow-bellied Sunbird. One, BF, 11 Dec 1996.

Nectarinia cyanolaema Blue-throated Sunbird. U, BF.

Nectarinia chloropygia Olive-bellied Sunbird. C, BF; F, NF.

\section{Zosteropidae}

Zosterops senegalensis Yellow White-eye. F, NF.

\section{Oriolidae}

Oriolus auratus African Golden Oriole. One, BF, 12 Apr 1995.

Oriolus brachyrhynchus Western Black-headed Oriole. F, BF.

Oriolus nigripennis Black-winged Oriole. U, BF.

\section{Laniidae}

Lanius collaris Fiscal Shrike. A pair, NF, 21 May 1995.

Lanius senator Woodchat Shrike. One, NF, 4 Feb 1996.

\section{Malaconotidae}

Dryoscopus sabini Sabine's Puffback. F, BF.

Nicator chloris Western Nicator. C, BF.

\section{Prionopidae}

Prionops caniceps Northern Red-billed Helmet Shrike. F, BF.

Prionops plumatus Straight-crested Helmet Shrike. Five, BF, 7 May 1995.

\section{Dicruridae}

Dicrurus atripennis Shining Drongo. F, BF.

Dicrurus adsimilis Fork-tailed Drongo. C, BF.

\section{Corvidae}

Corvus albus Pied Crow. C, NF.

\section{Sturnidae}

Poeoptera lugubris Narrow-tailed Starling. A flock of $c$. 70 birds, BF, 8 Feb 1996.

Onychognathus fulgidus Forest Chestnut-winged Starling. Three records, BF.

\section{Passeridae}

Passer griseus Grey-headed Sparrow. A, NF.

\section{Fringillidae}

Serinus mozambicus Yellow-fronted Canary. One, NF, 6 May 1995.

\section{Ploceidae}

Ploceus nigerrimus Vieillot's Black Weaver. A, NF.

Ploceus cucullatus Village Weaver. A, NF.

Ploceus nigricollis Spectacled Weaver. A male with nesting material, NF, 21 Jun 1997.

Ploceus tricolor Yellow-mantled Weaver. F, BF.

Ploceus albinucha Maxwell's Black Weaver. F, BF.

Ploceus preussi Preuss' Weaver. One, BF, 9 Aug 1997.

Malimbus nitens Blue-billed Malimbe. C, BF; F, NF.

Malimbus malimbicus Crested Malimbe. F, BF. 
Malimbus scutatus Red-vented Malimbe. F, BF.

Malimbus rubricollis Red-headed Malimbe. C, BF.

Amblyospiza albifrons Thick-billed Weaver. F, BF; U, NF.

Estrildidae

Nigrita canicapilla Grey-crowned Negrofinch. C, BF.

Nigrita bicolor Chestnut-breasted Negrofinch. C, BF.

Nigrita fusconota White-breasted Negrofinch. F, BF.

Pyrenestes sanguineus Crimson Seed-cracker. U, BF.

Spermophaga haematina Bluebill. C, BF.

Mandingoa nitidula Green Twinspot. Three males mist-netted, BF.

Estrilda melpoda Orange-cheeked Waxbill. C, NF.

Estrilda astrild Common Waxbill. U, NF.

Lonchura cucullata Bronze Mannikin. A, NF.

Viduidae

Vidua macroura Pin-tailed Widow. C, NF.

\section{Recent, but yet unconfirmed records:}

Campephaga lobata Western-Wattled Cuckoo-Shrike

Lamprotornis splendidus Splendid Glossy Starling

Lamprotornis cupreocauda Copper-tailed Glossy Starling

Old records, prior to logging:

Agelastes meleagrides White-breasted Guineafowl 


\section{Appendix B Species mist-netted within the study plot}

Total individuals and captures obtained by standardised mist-netting on the study plot during different sampling periods. Captures as sum from q samples. Systematics and nomenclature as in appendix A. Abbr.: Contr. - control compartment, Man. - managed compartment.

\begin{tabular}{|c|c|c|c|c|c|c|c|}
\hline & \multirow{3}{*}{$\begin{array}{l}\text { Total } \\
\text { ind. }\end{array}$} & \multicolumn{6}{|c|}{ Captures } \\
\hline & & \multicolumn{2}{|c|}{ 9 Feb - 21 Mar 1996} & \multicolumn{2}{|c|}{9 Sep - 15 Oct 1996} & \multicolumn{2}{|c|}{$21 \mathrm{Jul}-20$ Aug 1997} \\
\hline & & $\begin{array}{l}\text { Contr. } \\
(\mathrm{q}=8)\end{array}$ & $\begin{array}{l}\text { Man. } \\
(\mathrm{q}=8)\end{array}$ & $\begin{array}{l}\text { Contr. } \\
(\mathrm{q}=8)\end{array}$ & $\begin{array}{l}\text { Man. } \\
(\mathrm{q}=8)\end{array}$ & $\begin{array}{l}\text { Contr. } \\
(\mathrm{q}=8)\end{array}$ & $\begin{array}{l}\text { Man. } \\
(\mathrm{q}=8)\end{array}$ \\
\hline \multicolumn{8}{|l|}{ Accipitridae } \\
\hline Accipiter tachiro & 3 & 0 & 1 & 0 & 0 & 3 & 1 \\
\hline \multicolumn{8}{|l|}{ Phasianidae } \\
\hline Francolinus ahantensis & 1 & 0 & 0 & 0 & 0 & 0 & 1 \\
\hline Francolinus lathami & 1 & 0 & 0 & 1 & 0 & 1 & 0 \\
\hline \multicolumn{8}{|l|}{ Columbidae } \\
\hline Turtur brehmeri & 3 & 0 & 1 & 2 & 0 & 0 & 0 \\
\hline Turtur tympanistria & 2 & 0 & 1 & 0 & 1 & 0 & 0 \\
\hline \multicolumn{8}{|l|}{ Alcedinidae } \\
\hline Ceyx lecontei & 1 & 0 & 0 & 1 & 0 & 0 & 0 \\
\hline \multicolumn{8}{|l|}{ Bucerotidae } \\
\hline Tockus albocristatus & 3 & 1 & 0 & 0 & 1 & 0 & 2 \\
\hline \multicolumn{8}{|l|}{ Capitonidae } \\
\hline Trachyphonus purpuratus & 1 & 0 & 0 & 0 & 2 & 0 & 0 \\
\hline \multicolumn{8}{|l|}{ Indicatoridae } \\
\hline Indicator exilis & 1 & 1 & 0 & 0 & 0 & 0 & 0 \\
\hline \multicolumn{8}{|l|}{ Picidae } \\
\hline Campethera nivosa & 5 & 3 & 0 & 1 & 1 & 0 & 1 \\
\hline \multicolumn{8}{|l|}{ Eurylaimidae } \\
\hline Smithornis rufolateralis & 1 & 1 & 0 & 0 & 0 & 0 & 0 \\
\hline \multicolumn{8}{|l|}{ Pycnonotidae } \\
\hline Andropadus curvirostris & 18 & 3 & 4 & 0 & 1 & 6 & 9 \\
\hline Andropadus latirostris & 103 & 10 & 25 & 31 & 25 & 43 & 47 \\
\hline Andropadus virens & 54 & 1 & 22 & 3 & 28 & 2 & 19 \\
\hline Bleda canicapilla & 52 & 34 & 21 & 26 & 21 & 24 & 11 \\
\hline Bleda eximia & 5 & 3 & 1 & 2 & 0 & 1 & 1 \\
\hline Bleda syndactyla & 13 & 8 & 0 & 12 & 3 & 10 & 2 \\
\hline Criniger barbatus & 1 & 0 & 0 & 0 & 0 & 2 & 0 \\
\hline Criniger calurus & 5 & 0 & 2 & 3 & 1 & 0 & 0 \\
\hline Phyllastrephus albigularis & 40 & 11 & 6 & 25 & 8 & 19 & 7 \\
\hline \multicolumn{8}{|l|}{ Turdidae } \\
\hline Alethe diademata & 31 & 11 & 19 & 21 & 10 & 12 & 14 \\
\hline Neocossyphus finshii & 1 & 0 & 0 & 0 & 1 & 0 & 0 \\
\hline Neocossyphus poensis & 8 & 1 & 0 & 3 & 1 & 4 & 2 \\
\hline Stiphrornis erythrothorax & 8 & 5 & 1 & 5 & 0 & 2 & 1 \\
\hline \multicolumn{8}{|l|}{ Sylviidae } \\
\hline Camaroptera chloronota & 11 & 2 & 9 & 2 & 2 & 4 & 4 \\
\hline Camaroptera superciliaris & 3 & 1 & 1 & 0 & 2 & 0 & 2 \\
\hline Hylia prasina & 51 & 9 & 17 & 7 & 18 & 18 & 10 \\
\hline Macrosphenus kempi & 9 & 0 & 4 & 0 & 1 & 0 & 7 \\
\hline Sylvietta virens & 5 & 0 & 3 & 0 & 1 & 0 & 1 \\
\hline \multicolumn{8}{|l|}{ Muscicapidae } \\
\hline Muscicapa epulata & 7 & 0 & 3 & 4 & 0 & 0 & 4 \\
\hline
\end{tabular}


Appendix B (continued)

\begin{tabular}{|c|c|c|c|c|c|c|c|}
\hline & \multirow{3}{*}{$\begin{array}{c}\text { Total } \\
\text { ind. }\end{array}$} & \multicolumn{6}{|c|}{ Captures } \\
\hline & & \multicolumn{2}{|c|}{9 Feb - 21 Mar 1996} & \multicolumn{2}{|c|}{9 Sep - 15 Oct 1996} & \multicolumn{2}{|c|}{21 Jul - 20 Aug 1997} \\
\hline & & $\begin{array}{l}\text { Contr. } \\
(\mathrm{q}=8)\end{array}$ & $\begin{array}{l}\text { Man. } \\
(\mathrm{q}=8)\end{array}$ & $\begin{array}{l}\text { Contr. } \\
(\mathrm{q}=8)\end{array}$ & $\begin{array}{l}\text { Man. } \\
(\mathrm{q}=8)\end{array}$ & $\begin{array}{l}\text { Contr. } \\
(\mathrm{q}=8)\end{array}$ & $\begin{array}{l}\text { Man. } \\
(\mathrm{q}=8)\end{array}$ \\
\hline \multicolumn{8}{|l|}{ Monarchidae } \\
\hline Terpsiphone rufiventer & 19 & 0 & 4 & 4 & 5 & 5 & 6 \\
\hline Trochocercus nitens & 12 & 3 & 0 & 1 & 4 & 2 & 3 \\
\hline \multicolumn{8}{|l|}{ Platysteiridae } \\
\hline Diaphorophyia castanea & 3 & 2 & 0 & 1 & 0 & 0 & 0 \\
\hline \multicolumn{8}{|l|}{ Timaliidae } \\
\hline Illadopsis cleaveri & 8 & 3 & 4 & 1 & 2 & 0 & 1 \\
\hline Illadopsis fulvescens & 11 & 0 & 0 & 4 & 0 & 4 & 6 \\
\hline Illadopsis rufescens & 1 & 0 & 0 & 0 & 0 & 2 & 0 \\
\hline Illadopsis rufipennis & 14 & 4 & 9 & 0 & 5 & 2 & 1 \\
\hline \multicolumn{8}{|l|}{ Nectariniidae } \\
\hline Anthreptes collaris & 24 & 1 & 3 & 2 & 2 & 1 & 18 \\
\hline Anthreptes fraseri & 1 & 0 & 0 & 0 & 0 & 1 & 0 \\
\hline Nectarinia seimundi & 2 & 1 & 0 & 0 & 0 & 1 & 0 \\
\hline Nectarinia chloropygia & 1 & 0 & 0 & 0 & 2 & 0 & 0 \\
\hline Nectarinia olivacea & 114 & 50 & 36 & 34 & 21 & 47 & 21 \\
\hline \multicolumn{8}{|l|}{ Malaconotidae } \\
\hline Nicator chloris & 8 & 0 & 1 & 2 & 2 & 1 & 2 \\
\hline \multicolumn{8}{|l|}{ Dicruridae } \\
\hline Dicrurus adsimilis & 2 & 0 & 0 & 0 & 1 & 0 & 1 \\
\hline \multicolumn{8}{|l|}{ Ploceidae } \\
\hline Malimbus nitens & 15 & 0 & 2 & 4 & 5 & 3 & 4 \\
\hline \multicolumn{8}{|l|}{ Estrildidae } \\
\hline Mandingoa nitidula & 3 & 2 & 0 & 0 & 1 & 0 & 0 \\
\hline Nigrita bicolor & 4 & 0 & 1 & 0 & 1 & 0 & 2 \\
\hline Nigrita canicapilla & 4 & 0 & 0 & 0 & 2 & 1 & 1 \\
\hline Spermophaga haematina & 14 & 0 & 4 & 1 & 7 & 2 & 5 \\
\hline Total & 707 & 172 & 205 & 204 & 189 & 223 & 217 \\
\hline
\end{tabular}




\section{Appendix C Population data for the 136 species recorded within the 110 ha study plot}

Species marked with an asterisk are those with at least one definite breeding record (nest, young, adults carrying food or nesting material, adults mist-netted in breeding condition)

Capt: Total number of individual birds captured on the 110 ha study plot between April 1995 and August 1997.

Rec: Total number of accurately mapped visual or acoustic records within the 110 ha study plot. A record may represent isolated birds or groups.

Dens: Estimated number of pairs, singing adult males or social groups per 100 ha from mapping results in the 110 ha plot. In species for which underestimating is likely (non-vocal species such as woodpeckers, several canopy species or small understorey species for which the grid system is inadequate) the estimation is mainly based on the max. numbers of records obtained during one of the six censuses. Data from the two 16 ha mist-netting sites was used to correct for species obviously being under-represented in mapping data. In species with prominent territorial behaviour, density estimations are averages from censuses based on the median number of records obtained. + no reliable density estimation possible

Weight: Mean body weight (in g). When available, data given as mean for adult males. Data adopted from Brown et al. (1982), Urban et al. (1986), Fry et al. (1988), Keith et al. (1992), Urban et al. (1997) and Karr (1976) and completed with own data from mistnetting.

Diet: Preferred food, as given in the literature. C - carnivorous, I - insectivorous, F - frugivorous, $\mathrm{N}$ - nectarivorous, $\mathrm{G}$ - granivorous, $\mathrm{O}$ - omnivorous

Range: Size of geographic range in four classes (1) - Upper Guinean restricted, (2) - Guinea-Congolian rainforest biome restricted, (3) - African Forest, (4) Ubiquitous. (1) corresponds to the endemic bird area EBA085 (Upper Guinea) of Stattersfield et al. (1998), (2) corresponds to the category A3 (Guinea-Congo Forests biome A05), developed by Birdlife International (Fishpool in prep.).

Strat: Main vertical foraging stratum in mature rainforest in four classes. Data adopted from Gatter (1998). (1) - Ground and understorey, (2) - lower midstorey, (3) - upper midstorey, (4) canopy.
Capt Rec Dens Weight Diet Range Strat

Accipitridae

Aviceda cuculoides

Gypohierax angolensis*

Circaetus cinerascens

Polyboroides typus

Accipiter tachiro*

Urotriorchis macrourus

Hieraaetus dubius

Stephanoaetus coronatus

Phasianidae

Guttera pucherani*

Francolinus lathami*

Francolinus ahantensis*

Francolinus bicalcaratus

Rallidae

Himantornis haematopus

Sarothrura pulchra

Columbidae

Treron calva

Turtur brehmeri

Turtur tympanistria

Turtur afer

Columba iriditorques

Columba unicincta

Streptopelia semitorquata

Psittacidae

Psittacus erithacus

Poicephalus gulielmi

Musophagidae

Corythaeola cristata*

Tauraco macrorhynchus

$\begin{array}{lllllll}7 & 0.50 & 288 & \text { I } & 3 & 4\end{array}$

$\begin{array}{llllll}0.25 & 1505 & \mathrm{G} & 4\end{array}$

$+$

$\begin{array}{lllll}0.25 & 875 & \mathrm{C} & 4 & 3\end{array}$

42

$1902 \mathrm{C} 2$
$+\quad 492$

C $\quad 4-3$

+3750 C 34

$\begin{array}{lllll}1.75 & 1150 & G & 3 & 1\end{array}$

$\begin{array}{lllllll}2 & 8 & 1.75 & 254 & \mathrm{G} & 2 & 1\end{array}$

$\begin{array}{lllllll}1 & 21 & 6.50 & 510 & \mathrm{G} & 2 & 1\end{array}$

$\begin{array}{lllll}1 & 1.00 & 507 & \mathrm{G} & 1\end{array}$

$\begin{array}{cccccc}1 & 1.00 & 390 & \mathrm{O} & 2 & 1\end{array}$

$\begin{array}{llllll}7 & 4.50 & 45 & \text { I } & 2 & 1\end{array}$

$\begin{array}{llllll}36 & 7.25 & 210 & F & 4 & 4\end{array}$

$\begin{array}{lllllll}3 & 19 & 2.75 & 133 & \mathrm{G} & 2 & 1\end{array}$

$\begin{array}{lllllll}2 & 24 & 4.50 & 65 & \mathrm{G} & 3 & 1\end{array}$

$\begin{array}{llllll}8 & 1.75 & 67 & \mathrm{G} & 4 & 1\end{array}$

$\begin{array}{llllll}26 & 4.50 & 130 & \text { F } & 2 & 4\end{array}$

$\begin{array}{lllll}1-0.25 & 423 & \mathrm{~F} & 2 & 4\end{array}$

$\begin{array}{llllll}7 & 0.25 & 196 & \mathrm{G} & 4 & 1\end{array}$

$3+400 \quad \mathrm{O} \quad 2 \quad 4$

$\begin{array}{llllll}14 & 1.00 & 260 & \mathrm{G} & 3 & 4\end{array}$

$\begin{array}{llllll}11 & 1.50 & 903 & \mathrm{~F} & 3 & 4 \\ 25 & 2.25 & 246 & \mathrm{~F} & 2 & 4\end{array}$




\begin{tabular}{|c|c|c|c|c|c|c|c|}
\hline & Capt & $\operatorname{Rec}$ & Dens & Weight & Diet & Range & Strat \\
\hline \multicolumn{8}{|l|}{ Cuculidae } \\
\hline Centropus leucogaster & & 15 & 1.75 & 293 & I & 2 & 1 \\
\hline Cercococcyx olivinus & & 11 & 1.00 & 65 & $\mathrm{I}$ & 2 & 3 \\
\hline Cuculus solitarius* & & 3 & + & 75 & I & 4 & \\
\hline Cuculus clamosus & & 6 & + & 82 & I & 4 & \\
\hline Chrysococcyx cupreus & & 39 & 5.00 & 38 & I & 4 & 4 \\
\hline Chrysococcyx klaas & & 10 & 1.25 & 26 & I & 4 & 3 \\
\hline Ceuthmochares aereus & & 40 & 4.50 & 68 & I & 3 & 3 \\
\hline \multicolumn{8}{|l|}{ Strigidae } \\
\hline Strix woodfordii & & 1 & + & 248 & $\mathrm{C}$ & 3 & 1 \\
\hline Otus icterorhynchus & & 1 & + & 75 & $\mathrm{C}$ & 2 & \\
\hline \multicolumn{8}{|l|}{ Apodidae } \\
\hline Telacanthura melanopygia & & 1 & + & 52 & I & 2 & 4 \\
\hline Telacanthura ussheri & & 2 & + & 31 & I & 4 & 4 \\
\hline \multicolumn{8}{|l|}{ Trogonidae } \\
\hline Apaloderma narina & & 19 & 2.75 & 62 & I & 3 & 3 \\
\hline \multicolumn{8}{|l|}{ Alcedinidae } \\
\hline Halcyon badia & & 13 & 1.75 & 52 & I & 2 & 1 \\
\hline Halcyon senegalensis & & 10 & 1.75 & 53 & I & 4 & 4 \\
\hline Ceyx lecontei & 1 & & + & 10 & I & 2 & 1 \\
\hline \multicolumn{8}{|l|}{ Meropidae } \\
\hline Merops gularis & & 1 & + & 32 & I & 2 & 3 \\
\hline \multicolumn{8}{|l|}{ Phoeniculidae } \\
\hline Phoeniculus castaneiceps & & 3 & + & 24 & I & 2 & 4 \\
\hline Phoeniculus bollei & & 2 & + & 66 & I & 3 & 4 \\
\hline \multicolumn{8}{|l|}{ Bucerotidae } \\
\hline Tockus albocristatus & 4 & 24 & 2.00 & 297 & I & 2 & 2 \\
\hline Tockus hartlaubi & & 5 & 0.50 & 118 & I & 2 & 3 \\
\hline Tockus camurus & & 4 & 0.50 & 111 & I & 2 & 2 \\
\hline Tockus fasciatus & & 39 & 4.50 & 278 & $\mathrm{~F}$ & 2 & 3 \\
\hline Ceratogymna fistulator & & 2 & 0.25 & 463 & $\mathrm{~F}$ & 2 & 4 \\
\hline Ceratogymna cylindricus & & 16 & 0.50 & 921 & $\mathrm{~F}$ & 1 & 4 \\
\hline Ceratogymna elata & & 4 & + & 2100 & $\mathrm{~F}$ & 2 & 4 \\
\hline
\end{tabular}

\begin{tabular}{lccccccc}
\hline & Capt & Rec & Dens & Weight & Diet & Range & Strat \\
\hline Capitonidae & & & & & & & \\
Gymnobucco spp. & & 18 & 3.75 & 50 & F & 2 & 4 \\
Gymnobucco peli* & & 5 & 1.00 & 52 & F & 2 & 4 \\
Pogoniulus scolopaceus & 1 & 31 & 5.50 & 16 & O & 2 & 3 \\
Pogoniulus atroflavus & 1 & 7 & 1.75 & 18 & F & 2 & 4 \\
Pogoniulus subsulphureus & & 9 & 2.75 & 47 & F & 2 & 4 \\
Pogoniulus bilineatus & & 5 & 1.00 & 13 & F & 3 & 3 \\
Trachyphonus purpuratus & 2 & 31 & 3.75 & 86 & F & 3 & 2 \\
Tricholaema hirsuta & & 26 & 2.25 & 51 & F & 2 & 3
\end{tabular}

Indicatoridae

Indicator exilis

Indicator conirostris

Picidae

Campethera nivosa

Dendropicus pyrrhogaster

Eurylaimidae

Smithornis rufolateralis

Campephagidae

Coracina azurea

Pycnonotidae

Andropadus virens*

Andropadus gracilis

Andropadus ansorgei

Andropadus curvirostris*

Andropadus gracilirostris

Andropadus latirostris*

Calyptocichla serina

Baeopogon indicator

Phyllastrephus icterinus

Phyllastrephus albigularis*

Bleda syndactyla*

Bleda eximia*

$\begin{array}{lllll}1 & + & 16 & \mathrm{I} & 3 \\ & 1 & + & 29 & \mathrm{I}\end{array}$

$\begin{array}{lllllll}7 & 12 & 6.25 & 38 & \mathrm{I} & 2 & 1\end{array}$

$\begin{array}{llllll}26 & 5.50 & 70 & \text { I } & 2 & 3\end{array}$

Bleda canicapilla*

$\begin{array}{ccccccc}1 & 17 & 1.00 & 29 & \text { I } & 2 & 1 \\ & & & & & & \\ & 9 & 1.75 & 46 & \text { I } & 2 & 4 \\ & & & & & & \\ 77 & 99 & 19.00 & 24 & \text { O } & 3 & 1 \\ & 17 & 3.75 & 21 & \text { I } & 2 & 3 \\ & 4 & 1.25 & 20 & \text { I } & 2 & 4 \\ 23 & 70 & 11.0 & 24 & \text { O } & 2 & 3 \\ & 24 & 5.50 & 31 & \text { I } & 3 & 4 \\ 186 & 138 & 34.50 & 25 & \text { O } & 3 & 1 \\ & 3 & 1.00 & 40 & \text { F } & 2 & 4 \\ & 21 & 4.50 & 48 & \text { F } & 2 & 3 \\ & 1 & + & 20 & \text { I } & 2 & 1 \\ 89 & 64 & 14.50 & 25 & \text { I } & 2 & 1 \\ 39 & 31 & 3.50 & 46 & \text { I } & 2 & 1 \\ 9 & 6 & 1.75 & 48 & \text { I } & 1 & 1 \\ 149 & 83 & 15.50 & 41 & \text { I } & 2 & 1\end{array}$




\begin{tabular}{|c|c|c|c|c|c|c|c|}
\hline & Capt & $\operatorname{Rec}$ & Dens & Weight & Diet & Range & Strat \\
\hline \multicolumn{8}{|l|}{$\overline{\text { Pycnonotidae (cont.) }}$} \\
\hline Criniger barbatus & 2 & 14 & 2.75 & 44 & I & 2 & 1 \\
\hline Criniger calurus & 6 & 70 & 9.00 & 32 & I & 2 & 2 \\
\hline Pycnonotus barbatus & & 19 & 1.75 & 40 & $\mathrm{O}$ & 4 & 4 \\
\hline \multicolumn{8}{|l|}{ Turdidae } \\
\hline Stiphrornis erythrothorax* & 17 & 33 & 4.50 & 15 & I & 2 & 1 \\
\hline Alethe diademata* & 93 & 67 & 13.50 & 32 & I & 2 & 1 \\
\hline Neocossyphus poensis* & 12 & 6 & 8.25 & 56 & I & 2 & 1 \\
\hline Neocossyphus finschii & 1 & 18 & 3.50 & 37 & I & 2 & 2 \\
\hline \multicolumn{8}{|l|}{ Sylviidae } \\
\hline Apalis sharpei & & 33 & 5.50 & 9 & I & 1 & 3 \\
\hline Camaroptera brachyura & 1 & 5 & 1.00 & 11 & I & 4 & 1 \\
\hline Camaroptera superciliaris* & 6 & 57 & 8.25 & 8 & I & 2 & 2 \\
\hline Camaroptera chloronota* & 25 & 49 & 7.75 & 11 & I & 2 & 1 \\
\hline Macrosphenus kempi* & 13 & 87 & 12.25 & 14 & I & 2 & 1 \\
\hline Macrosphenus concolor & & 94 & 15.00 & 14 & I & 2 & 3 \\
\hline Eremomela badiceps & & 6 & 1.75 & 10 & I & 2 & 4 \\
\hline Sylvietta virens* & 6 & 39 & 5.50 & 7 & I & 2 & 2 \\
\hline Sylvietta denti & & 1 & + & 8 & I & 2 & 4 \\
\hline Hyliota violacea & & 3 & 1.00 & 16 & I & 3 & 4 \\
\hline Hylia prasina* & 90 & 138 & 27.25 & 12 & I & 2 & 1 \\
\hline \multicolumn{8}{|l|}{ Muscicapidae } \\
\hline Melaenornis ocreatus & & 20 & 3.50 & 34 & I & 2 & 3 \\
\hline Muscicapa caerulescens & & 2 & + & 14 & I & 4 & 3 \\
\hline Muscicapa epulata* & 11 & 2 & 8.00 & 10 & I & 2 & 4 \\
\hline Muscicapa ussheri & & 1 & + & 18 & I & 2 & 4 \\
\hline \multicolumn{8}{|l|}{ Monarchidae } \\
\hline Erythrocercus mccallii & & 12 & 1.75 & 7 & I & 2 & 3 \\
\hline Trochocercus nitens* & 14 & 62 & 7.75 & 12 & I & 2 & 3 \\
\hline Terpsiphone rufiventer* & 32 & 103 & 14.50 & 15 & I & 2 & 2 \\
\hline \multicolumn{8}{|l|}{ Platysteiridae } \\
\hline Diaphorophyia castanea & 3 & 31 & 7.25 & 12 & I & 2 & 2 \\
\hline \multicolumn{8}{|l|}{ Timaliidae } \\
\hline Illadopsis fulvescens* & 14 & 152 & 30.00 & 30 & I & 2 & 1 \\
\hline
\end{tabular}

\begin{tabular}{|c|c|c|c|c|c|c|c|}
\hline & Capt & $\operatorname{Rec}$ & Dens & Weight & Diet & Range & Strat \\
\hline \multicolumn{8}{|l|}{ Timaliidae (cont.) } \\
\hline Illadopsis rufipennis* & 21 & 39 & 10.00 & 28 & I & 3 & 1 \\
\hline Illadopsis cleaveri* & 11 & 4 & 7.25 & 27 & I & 2 & 1 \\
\hline Illadopsis rufescens* & 2 & 6 & 1.00 & 37 & I & 1 & 1 \\
\hline \multicolumn{8}{|l|}{ Paridae } \\
\hline Parus funereus & & 5 & 1.00 & & I & 2 & 4 \\
\hline \multicolumn{8}{|l|}{ Nectariniidae } \\
\hline Anthreptes fraseri* & 2 & 19 & 5.50 & 11 & $\mathrm{~N}$ & 2 & 2 \\
\hline Anthreptes collaris* & 27 & 29 & 9.00 & 8 & $\mathrm{~N}$ & 3 & 3 \\
\hline Nectarinia seimundi & 2 & & + & 6 & $\mathrm{~N}$ & 3 & 3 \\
\hline Nectarinia olivacea* & 226 & 102 & 26.50 & 9 & $\mathrm{~N}$ & 3 & 1 \\
\hline Nectarinia adelberti & & 1 & + & & $\mathrm{N}$ & 2 & 4 \\
\hline Nectarinia cyanolaema & & 3 & + & & $\mathrm{N}$ & 2 & 3 \\
\hline Nectarinia chloropygia & 2 & 32 & 7.25 & 5 & $\mathrm{~N}$ & 3 & 2 \\
\hline \multicolumn{8}{|l|}{ Oriolidae } \\
\hline Oriolus brachyrhynchus & & 48 & 6.25 & 46 & $\mathrm{I}$ & 2 & 3 \\
\hline Oriolus nigripennis & & 3 & + & & $\mathrm{I}$ & 2 & 3 \\
\hline \multicolumn{8}{|l|}{ Malaconotidae } \\
\hline Dryoscopus sabini & & 10 & 1.00 & & I & 2 & 4 \\
\hline Nicator chloris* & 8 & 81 & 10.5 & 42 & I & 2 & 3 \\
\hline \multicolumn{8}{|l|}{ Prionopidae } \\
\hline Prionops caniceps & & 9 & 1.00 & & I & 2 & 4 \\
\hline \multicolumn{8}{|l|}{ Dicruridae } \\
\hline Dicrurus adsimilis* & 2 & 69 & 9.50 & 48 & I & 4 & 4 \\
\hline Dicrurus atripennis & & 5 & 1.50 & & I & 2 & 3 \\
\hline \multicolumn{8}{|l|}{ Sturnidae } \\
\hline Onychognathus fulgidus* & & 3 & 1.00 & & $\mathrm{I}$ & 2 & 4 \\
\hline \multicolumn{8}{|l|}{ Ploceidae } \\
\hline Ploceus tricolor* & & 9 & 1.50 & & I & 2 & 4 \\
\hline Ploceus albinucha & & 9 & 1.50 & & $\mathrm{I}$ & 2 & 3 \\
\hline Ploceus preussi & & 1 & + & & I & 2 & 4 \\
\hline Malimbus nitens* & 19 & 15 & 1.00 & 33 & $\mathrm{I}$ & 2 & 3 \\
\hline Malimbus malimbicus & & 8 & 1.00 & & I & 2 & 3 \\
\hline Malimbus scutatus* & & 4 & 1.75 & & I & 2 & 2 \\
\hline
\end{tabular}




\begin{tabular}{lccccccc}
\hline & Capt & Rec & Dens & Weight & Diet & Range & Strat \\
\hline Ploceidae (cont.) & & & & & & & \\
$\quad$ Malimbus rubricollis* & & 41 & 4.00 & & I & 2 & 4 \\
$\quad \begin{array}{l}\text { Amblyospiza albifrons } \\
\text { Estrildidae }\end{array}$ & & 3 & + & 32 & G & 4 & 4 \\
$\quad$ Nigrita canicapilla & 4 & 24 & 6.25 & 15 & I & 3 & 4 \\
$\quad$ Nigrita bicolor & 4 & 4 & 3.50 & 11 & I & 2 & 1 \\
$\quad$ Nigrita fusconota & & 6 & 1.50 & & I & 2 & 4 \\
$\quad$ Spermophaga haematina* & 19 & 3 & 7.25 & 18 & G & 2 & 1 \\
$\quad$ Mandingoa nitidula & 3 & 1 & + & 11 & I & 2 & 1 \\
\hline
\end{tabular}




\section{Appendix D Spot maps}

The observations drawn on the maps are derived exclusively from the six censuses of the standardised spotmapping program. No additional records were included. As territorial limits for most of the species were insufficiently known, only the accurately mapped acoustical and visual observations are given (one exception: Little Greenbul Andropadus virens). Species appear in systematical order. Localities of species that were recorded only once (21 in total), are put together on a separate map, as were mixed bird parties (one map per census A-F, no flocks during census C). Species on these maps are represented by a six-letter code (see below).

Symbols and map:
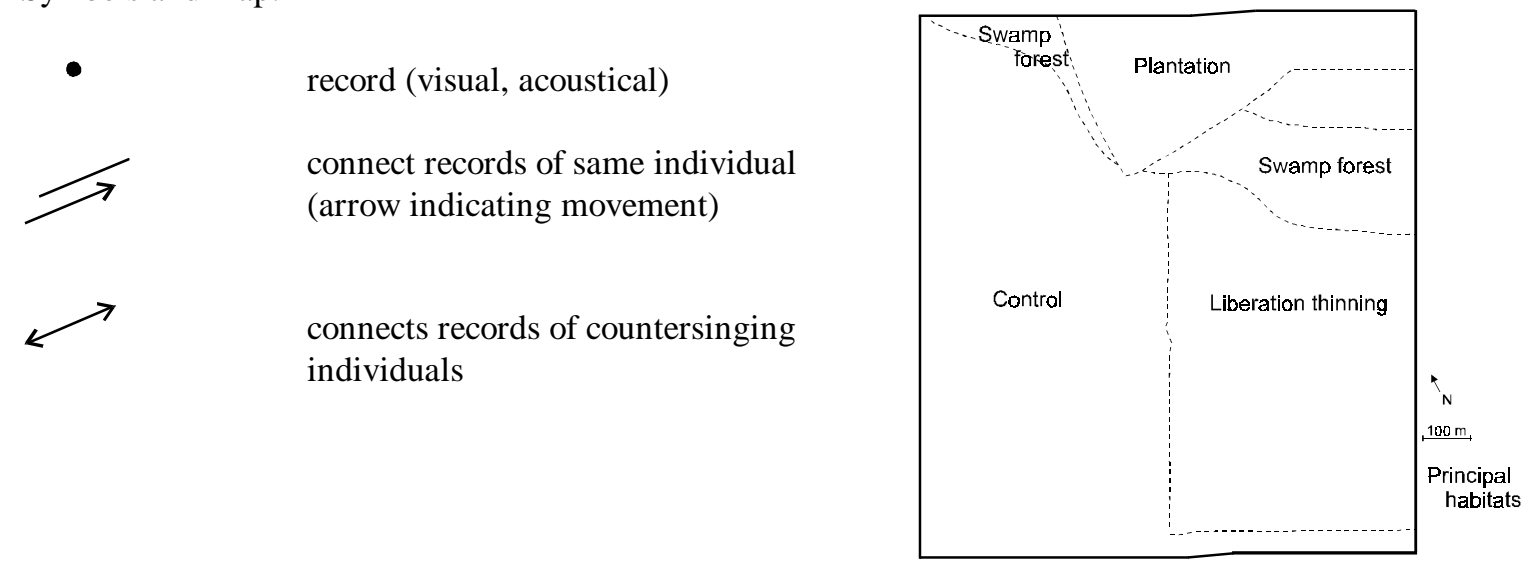

Species codes (in alphabetical order):

\begin{tabular}{|c|c|c|}
\hline AMBALB & Amblyospiza albifrons & Ploceidae \\
\hline ANDCUR & Andropadus curvirostris & Pycnonotidae \\
\hline ANDGRA & Andropadus gracilis & Pycnonotidae \\
\hline ANDVIR & Andropadus virens & Pycnonotidae \\
\hline ANTFRA & Anthreptes fraseri & Nectariniidae \\
\hline BLECAN & Bleda canicapilla & Pycnonotidae \\
\hline CALSER & Calyptocichla serina & Pycnonotidae \\
\hline CAMNIV & Campethera nivosa & Picidae \\
\hline CAMSUP & $\begin{array}{l}\text { Camaroptera } \\
\text { superciliaris }\end{array}$ & Sylviidae \\
\hline CEUAER & Ceuthmochares aereus & Cuculidae \\
\hline CHRCUP & Chrysococcyx cupreus & Cuculidae \\
\hline COLUNI & Columba unicincta & Columbidae \\
\hline CORAZU & Coracina azurea & Campephagidae \\
\hline CRIBAR & Criniger barbatus & Pycnonotidae \\
\hline CRICAL & Criniger calurus & Pycnonotidae \\
\hline CUCSOL & Cuculus solitarius & Cuculidae \\
\hline DICADS & Dicrurus adsimilis & Dicruridae \\
\hline DICATR & Dicrurus atripennis & Dicruridae \\
\hline EREBAD & Eremomela badiceps & Sylviidae \\
\hline ERYMCC & Erythrocercus mccallii & Monarchidae \\
\hline FRABIC & $\begin{array}{l}\text { Francolinus } \\
\text { bicalcaratus }\end{array}$ & Phasianidae \\
\hline FRAOCR & Melaenornis ocreatus & Muscicapidae \\
\hline GYPANG & Gypohierax angolensis & Accipitridae \\
\hline HYLPRA & Hylia prasina & Sylviidae \\
\hline HYLVIO & Hyliota violacea & Sylviidae \\
\hline MACCON & Macrosphenus concolor & Sylviidae \\
\hline MALMAL & Malimbus malimbicus & Ploceidae \\
\hline MALNIT & Malimbus nitens & Ploceidae \\
\hline MALRUB & Malimbus rubricollis & Ploceidae \\
\hline
\end{tabular}

\begin{tabular}{|c|c|c|}
\hline MALSP & Malimbus sp. & Ploceidae \\
\hline MERGUL & Merops gularis & Meropidae \\
\hline MUSEPU & Muscicapa epulata & Muscicapidae \\
\hline NECADE & Nectarinia adelberti & Nectariniidae \\
\hline NECOLI & Nectarinia olivacea & Nectariniidae \\
\hline NECSP & Nectarinia sp. & Nectariniidae \\
\hline NEOFIN & Neocossyphus finshii & Turdidae \\
\hline NIGFUS & Nigrita fusconota & Estrildidae \\
\hline ORIBRA & Oriolus brachyrhynchus & Oriolidae \\
\hline PHOBOL & Phoeniculus bollei & Phoeniculidae \\
\hline PHOCAS & $\begin{array}{l}\text { Phoeniculus } \\
\text { castaneiceps }\end{array}$ & Phoeniculidae \\
\hline PHYALB & $\begin{array}{l}\text { Phyllastrephus } \\
\text { albigularis }\end{array}$ & Pycnonotidae \\
\hline PHYICT & Phyllastrephus icterinus & Pycnonotidae \\
\hline PLACAS & $\begin{array}{l}\text { Diaphorophyia } \\
\text { castanea }\end{array}$ & Platysteiridae \\
\hline PLOALB & Ploceus albinucha & Ploceidae \\
\hline PLOTRI & Ploceus tricolor & Ploceidae \\
\hline POLTYP & Polyboroides typus & Accipitridae \\
\hline SPEHAE & $\begin{array}{l}\text { Spermophaga } \\
\text { haematina }\end{array}$ & Estrildidae \\
\hline STECOR & $\begin{array}{l}\text { Stephanoaetus } \\
\text { coronatus }\end{array}$ & Accipitridae \\
\hline SYLDEN & Sylvietta denti & Sylviidae \\
\hline TELUSS & Telacanthura ussheri & Apodidae \\
\hline TRAPUR & $\begin{array}{l}\text { Trachyphonus } \\
\text { purpuratus }\end{array}$ & Capitonidae \\
\hline TRIFUL & Illadopsis fulvescens & Timaliidae \\
\hline TRIHIR & Tricholaema hirsuta & Capitonidae \\
\hline
\end{tabular}

Other abbreviations:

F/M Female/Male

JUV Juvenile 


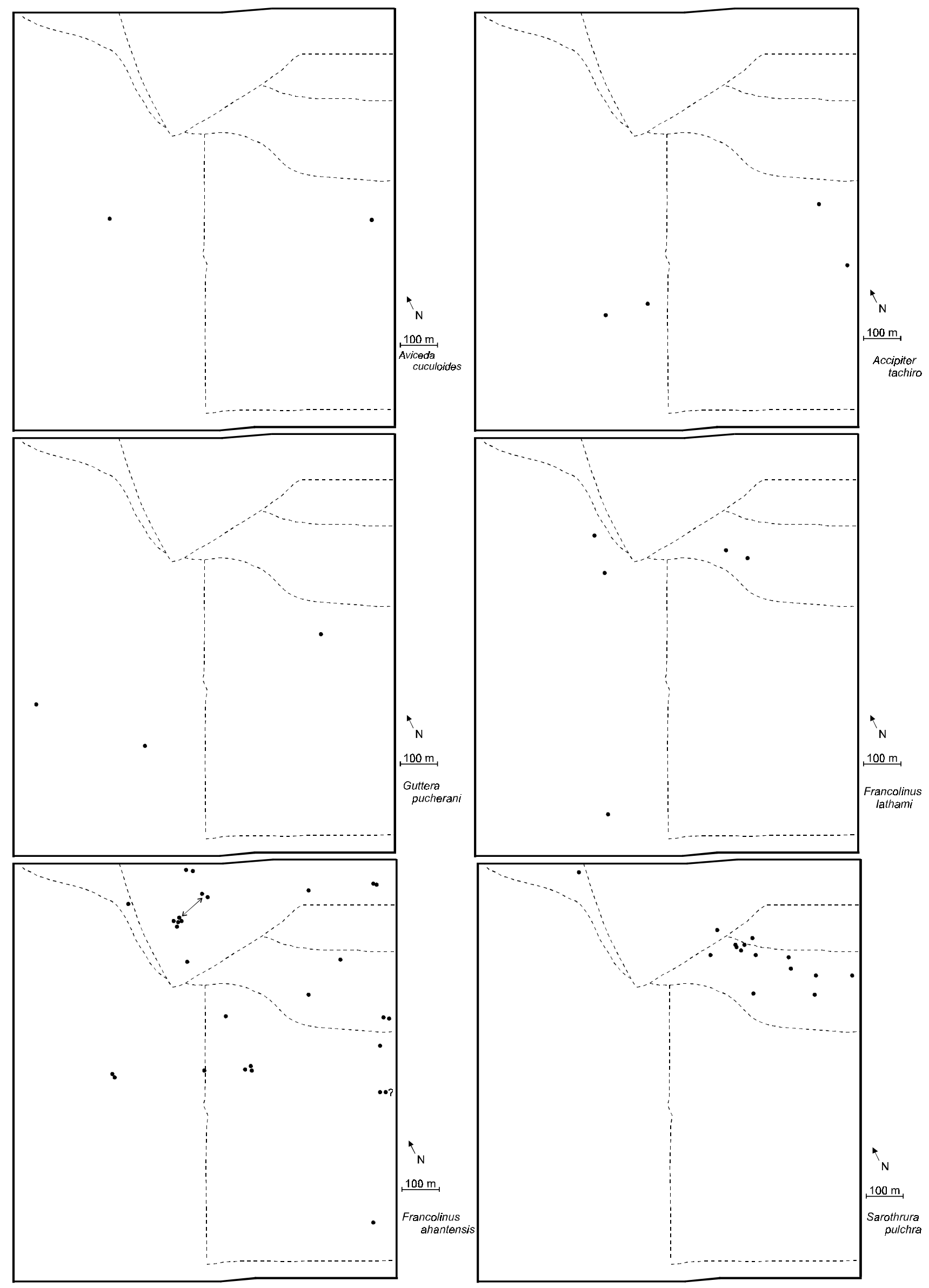




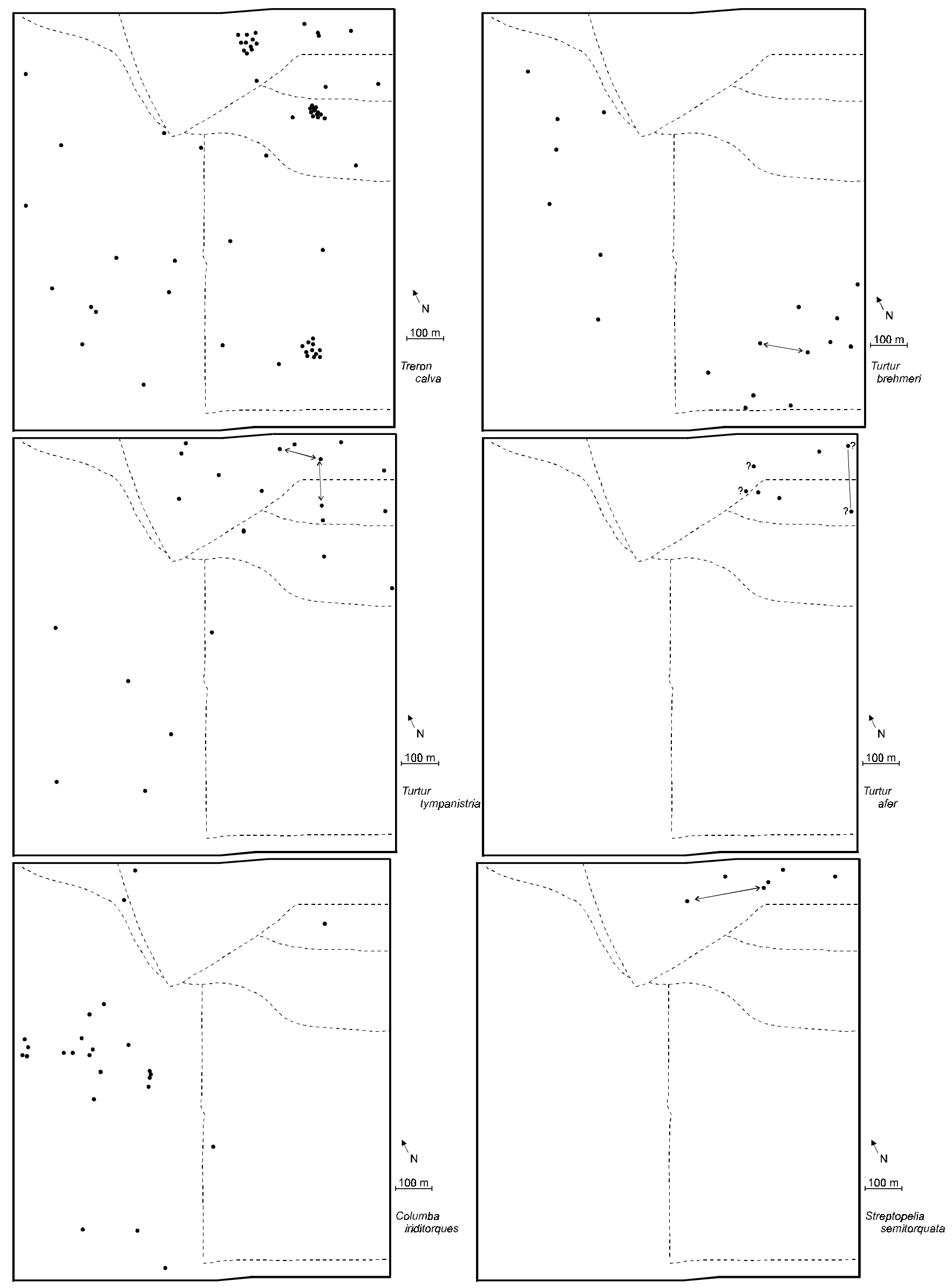




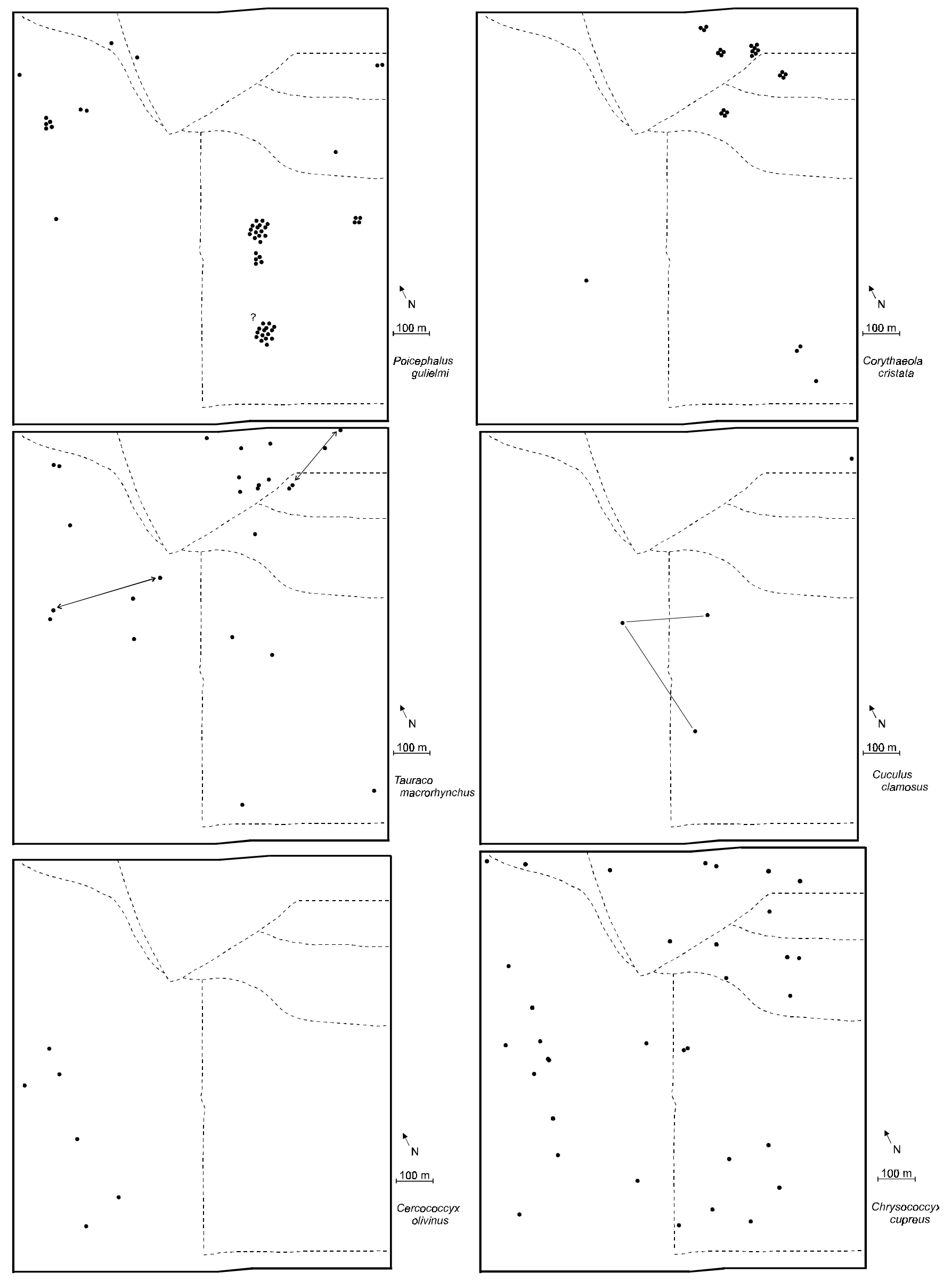




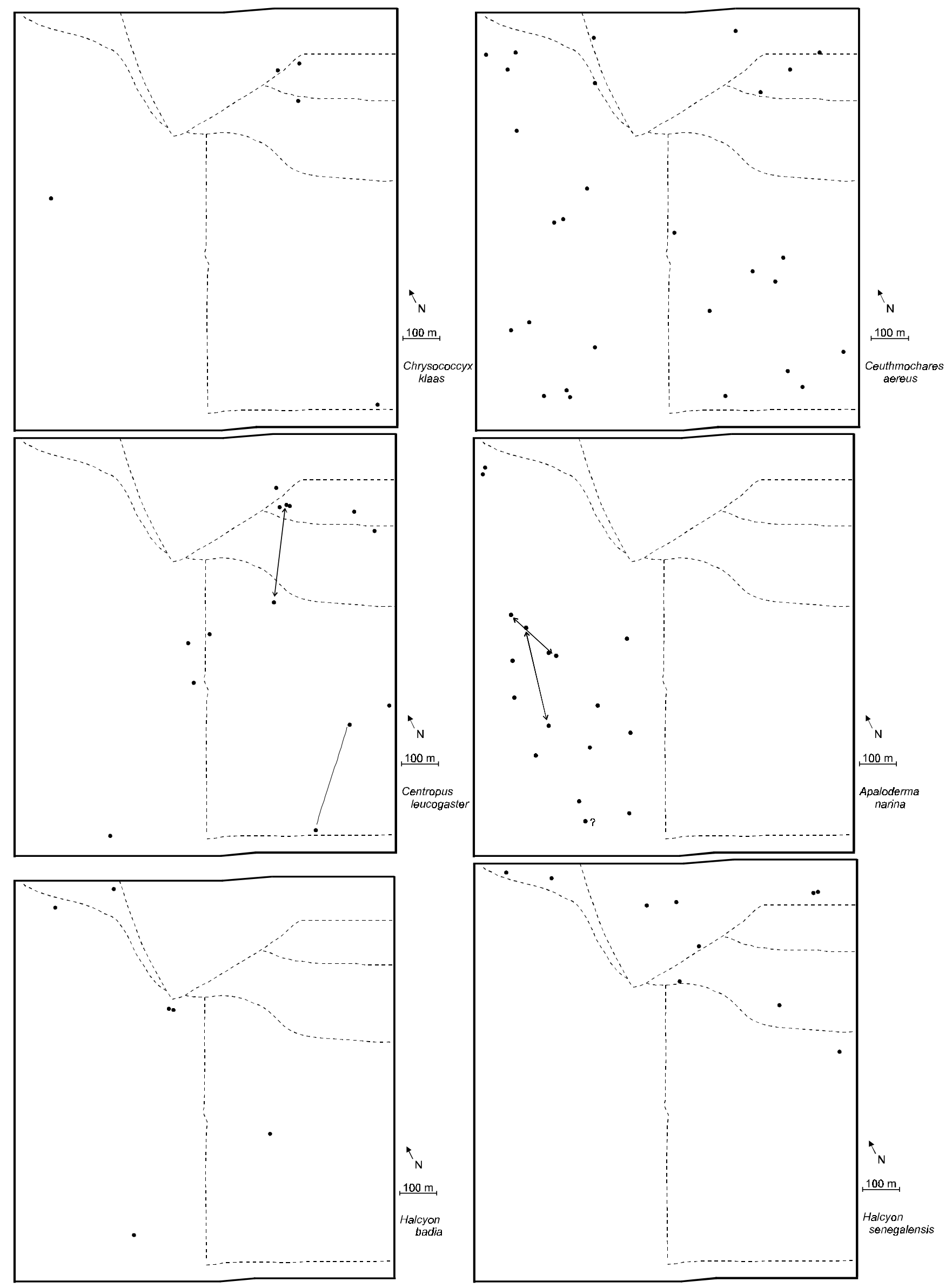




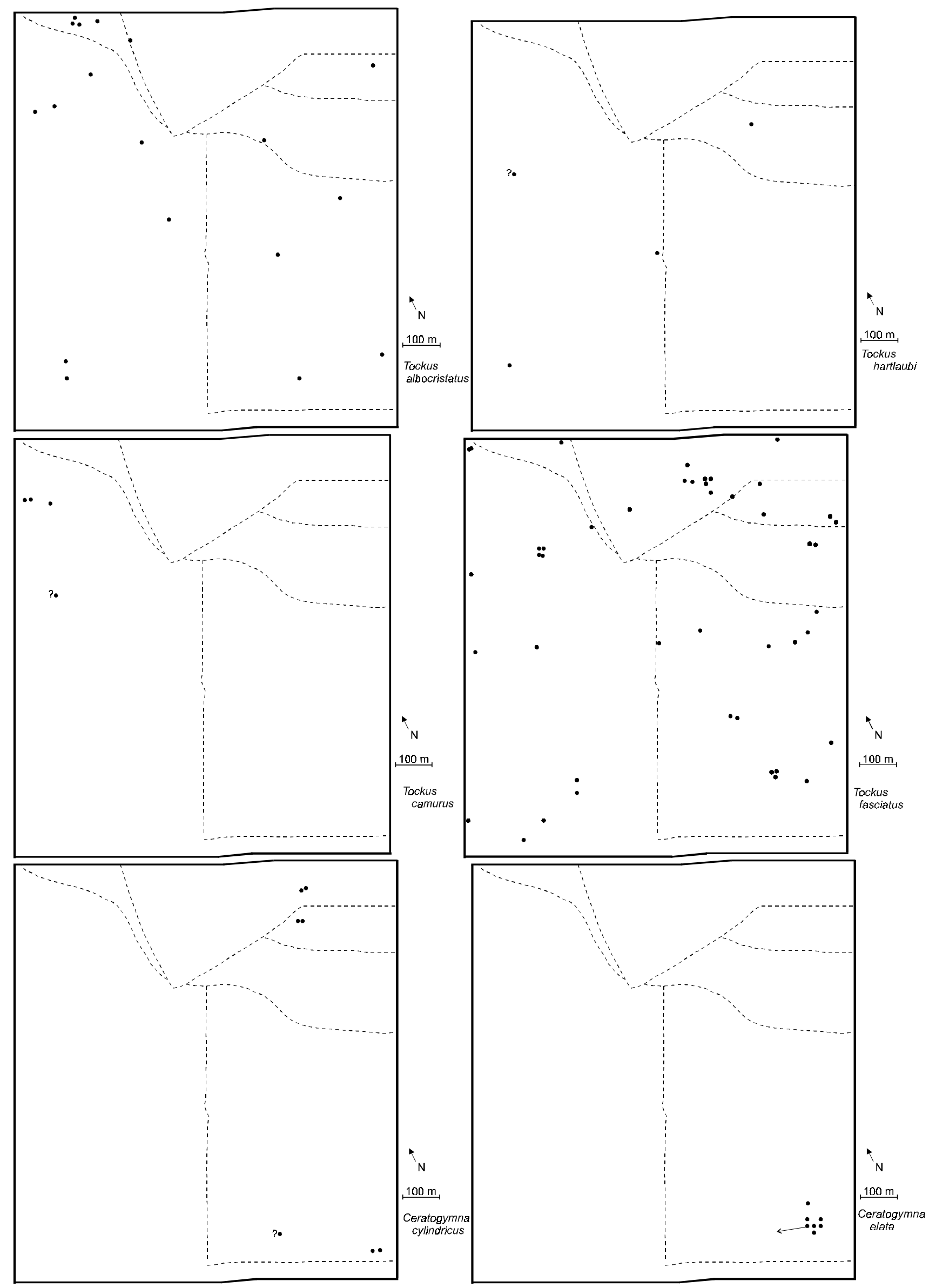




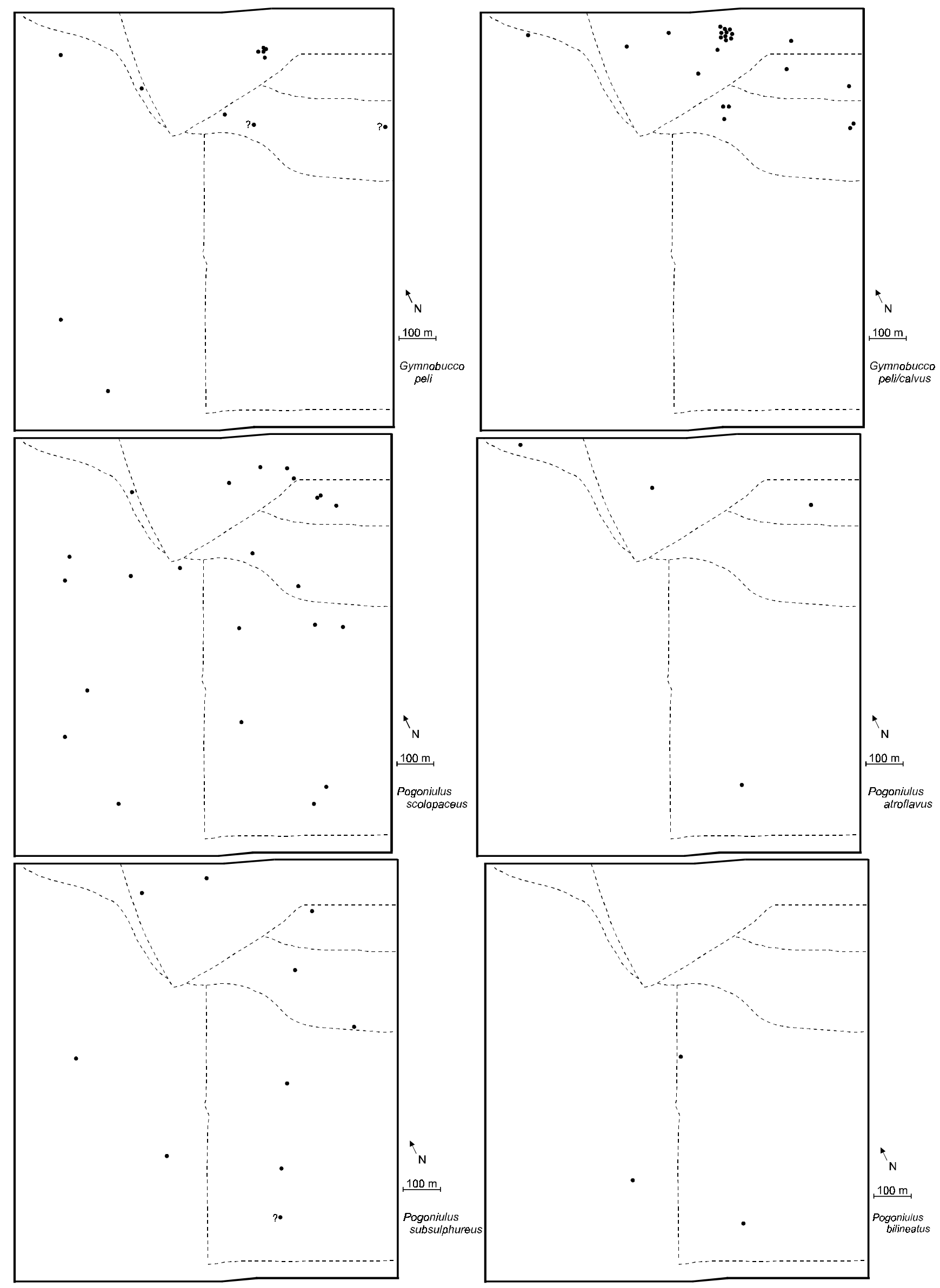



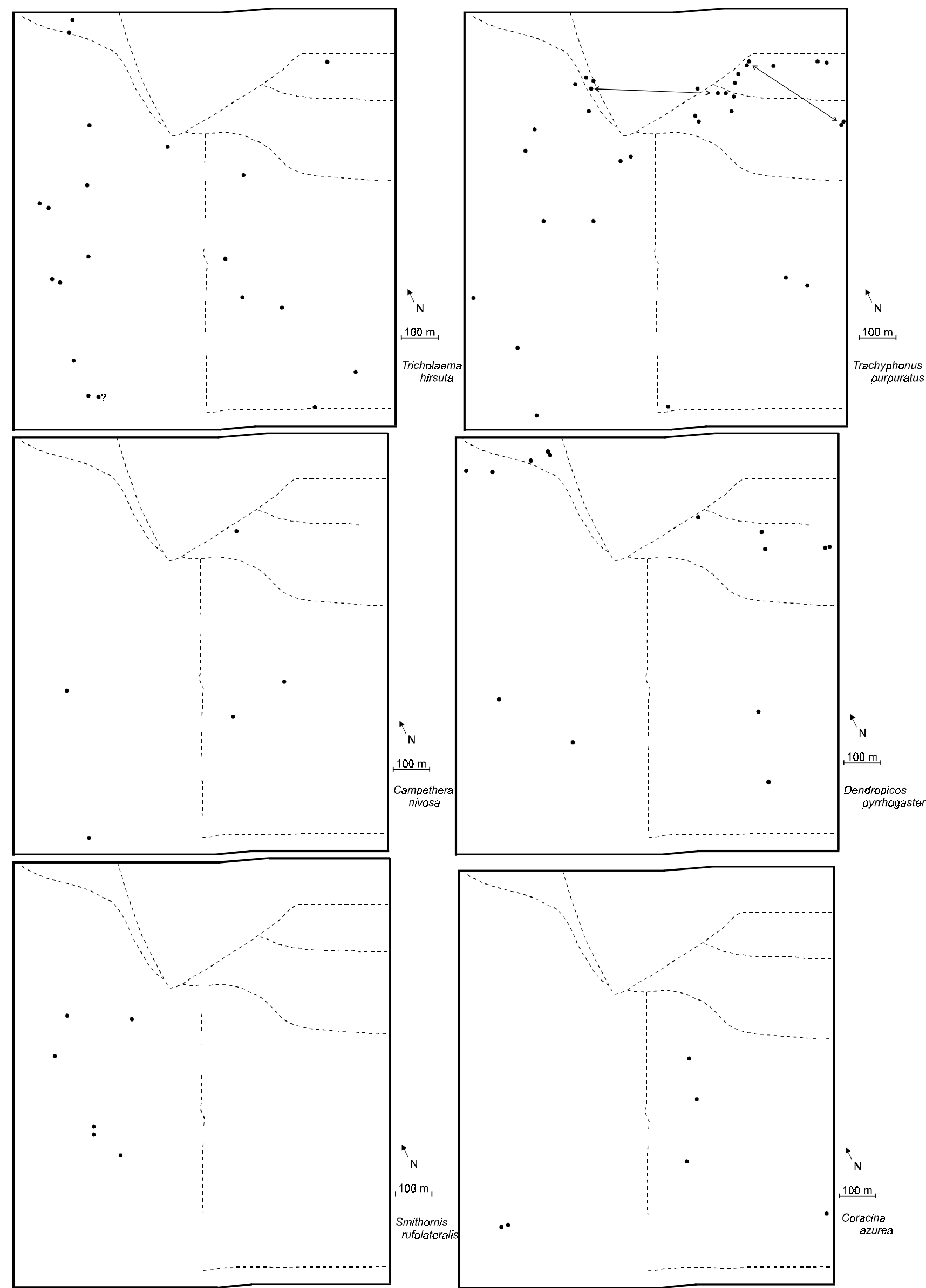


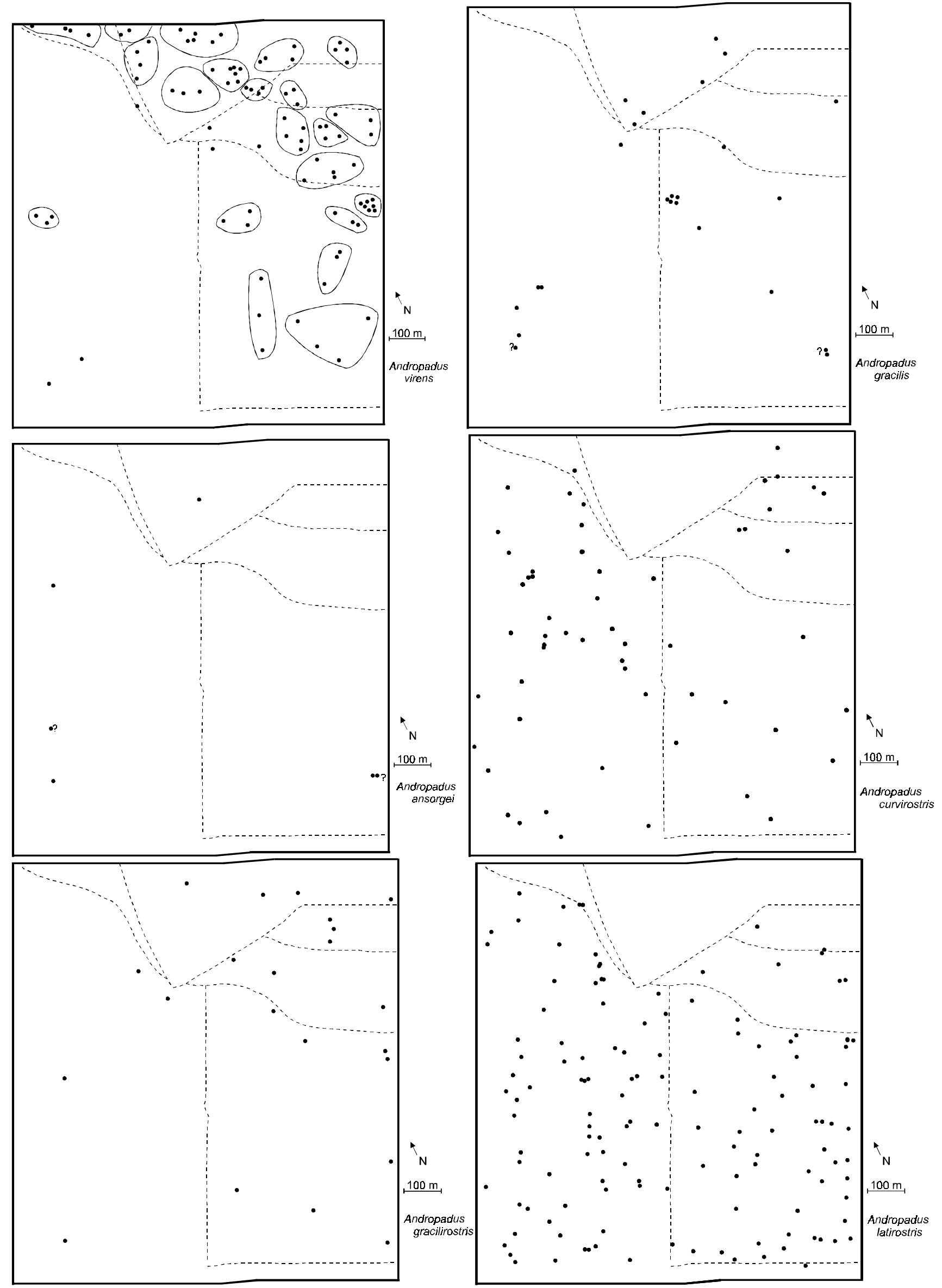




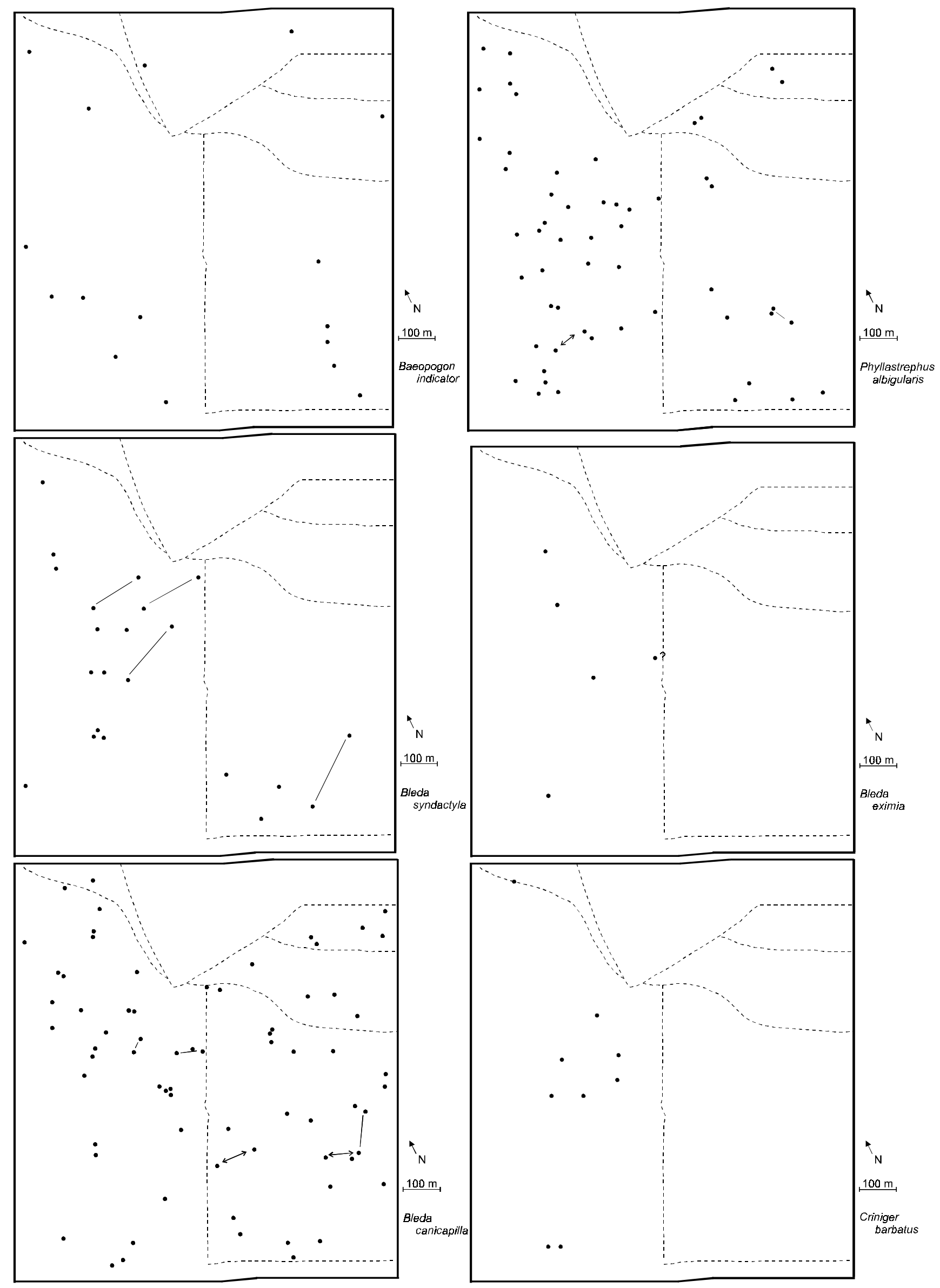



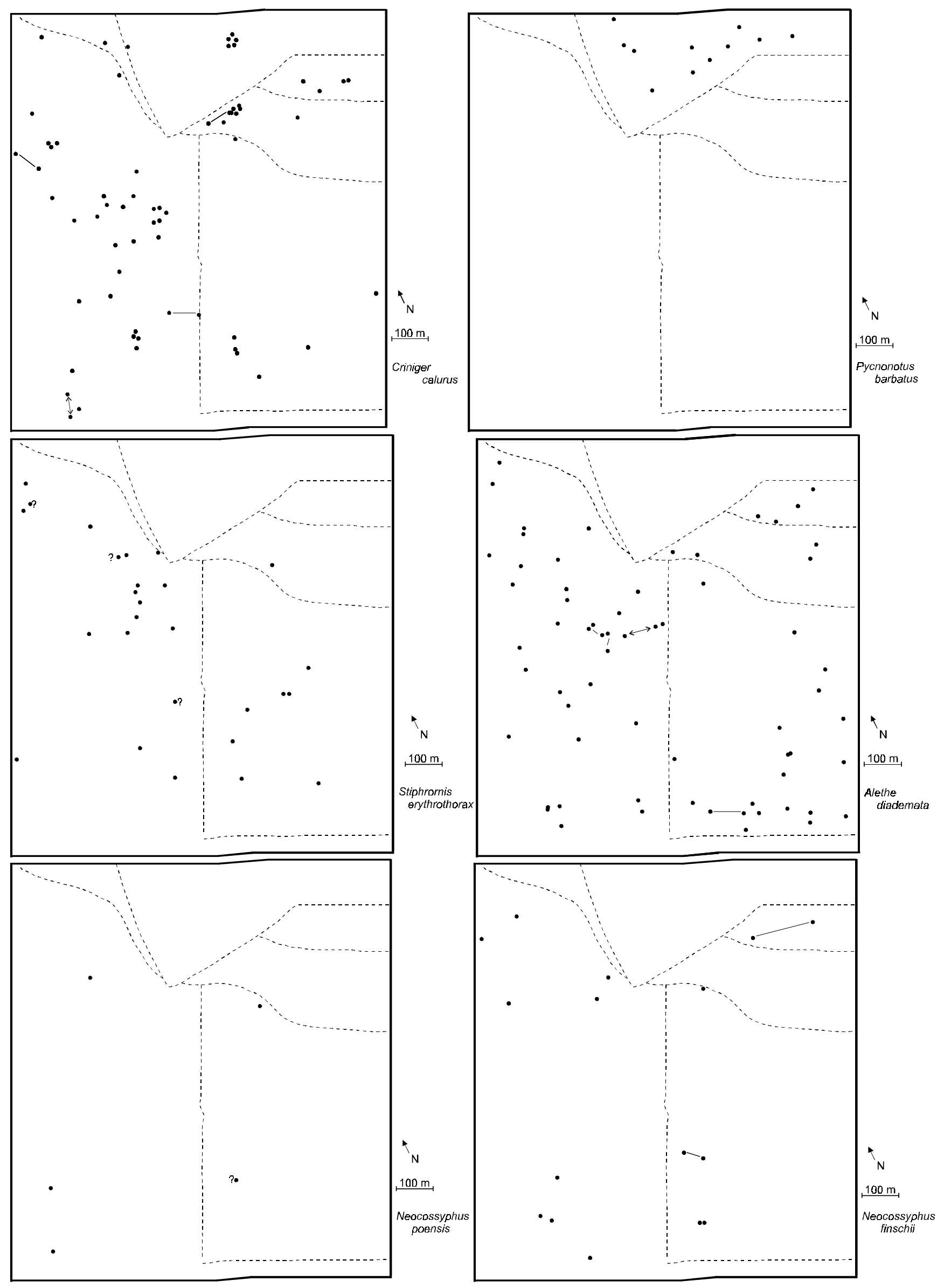


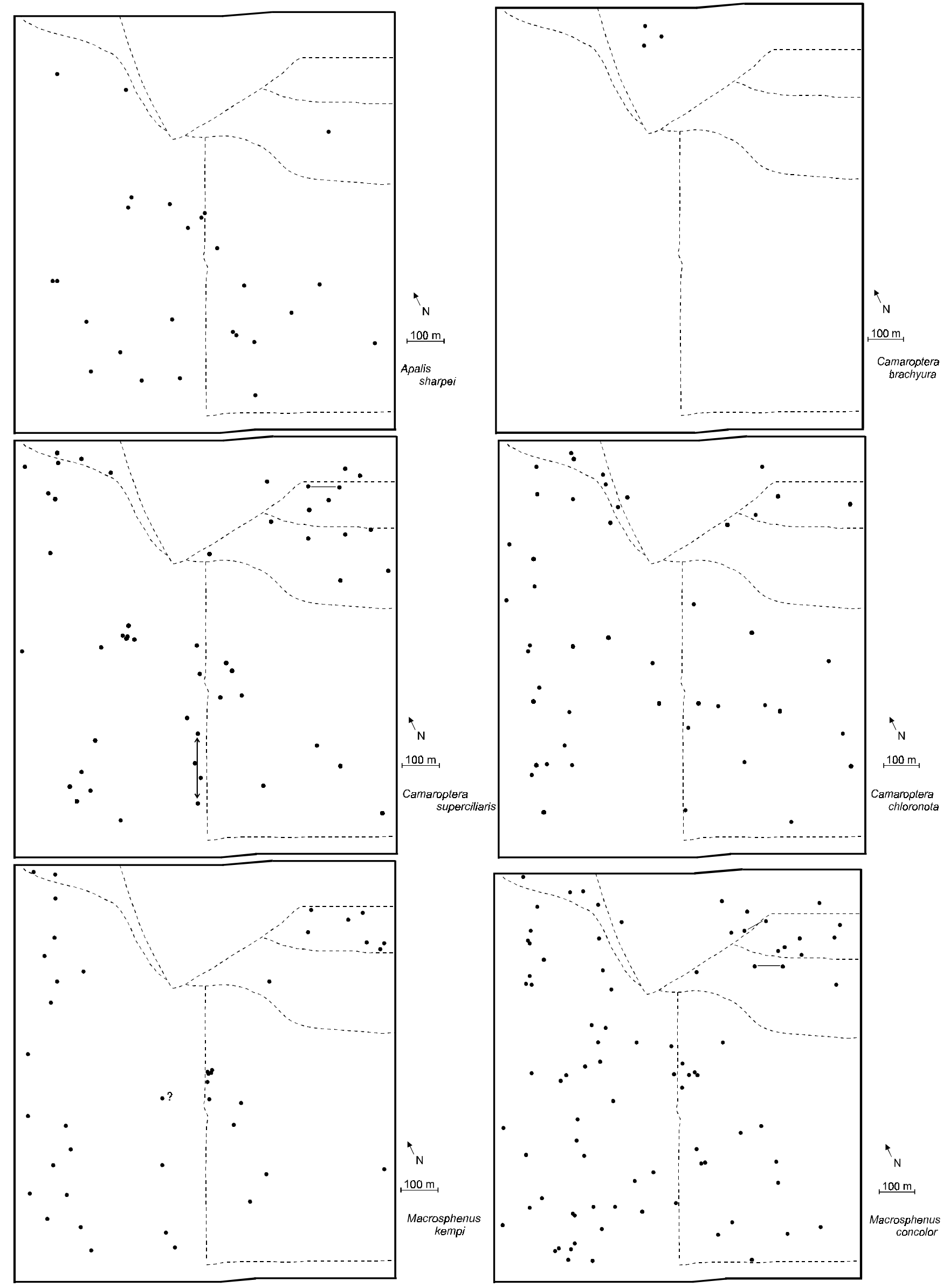



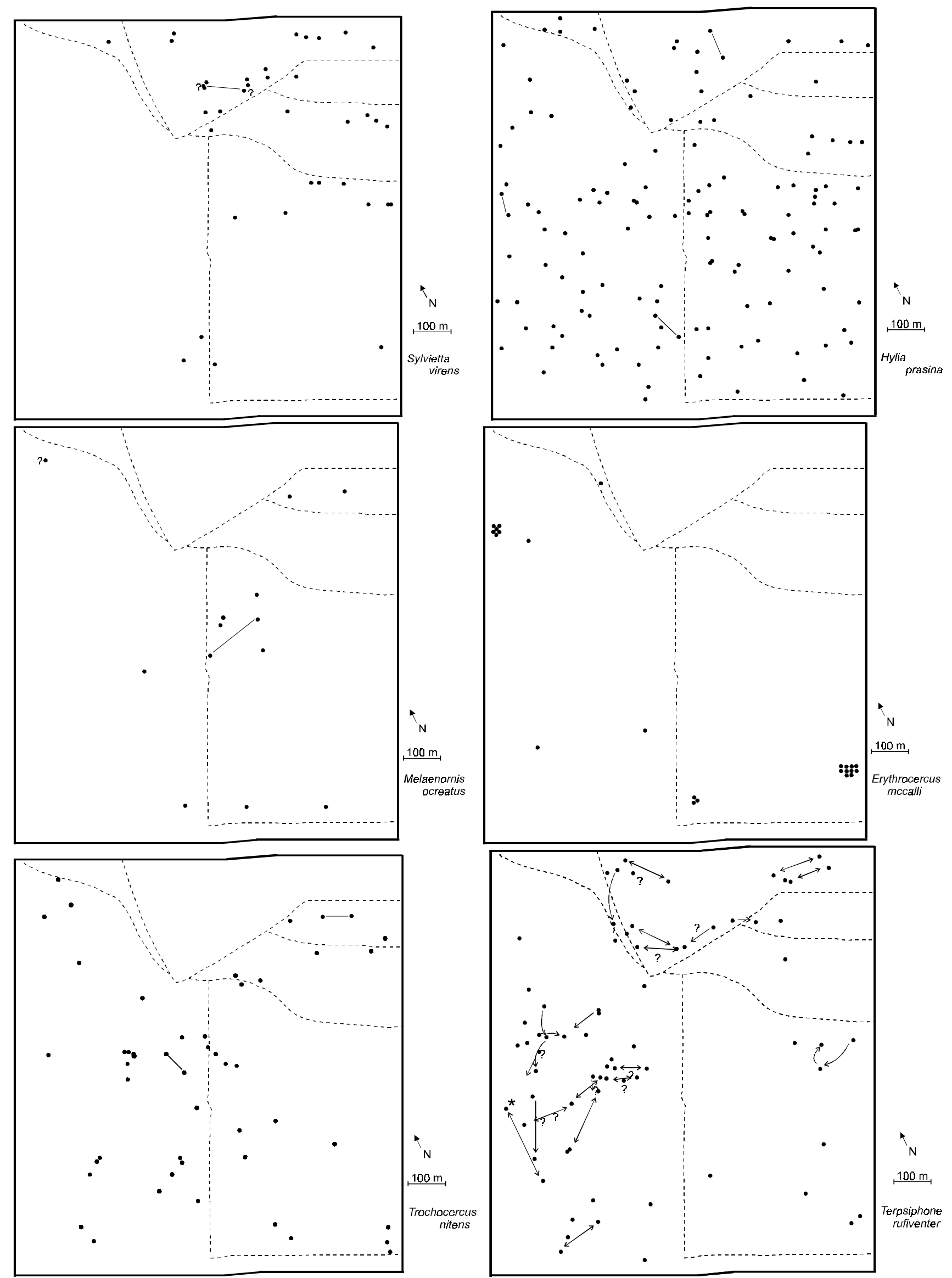

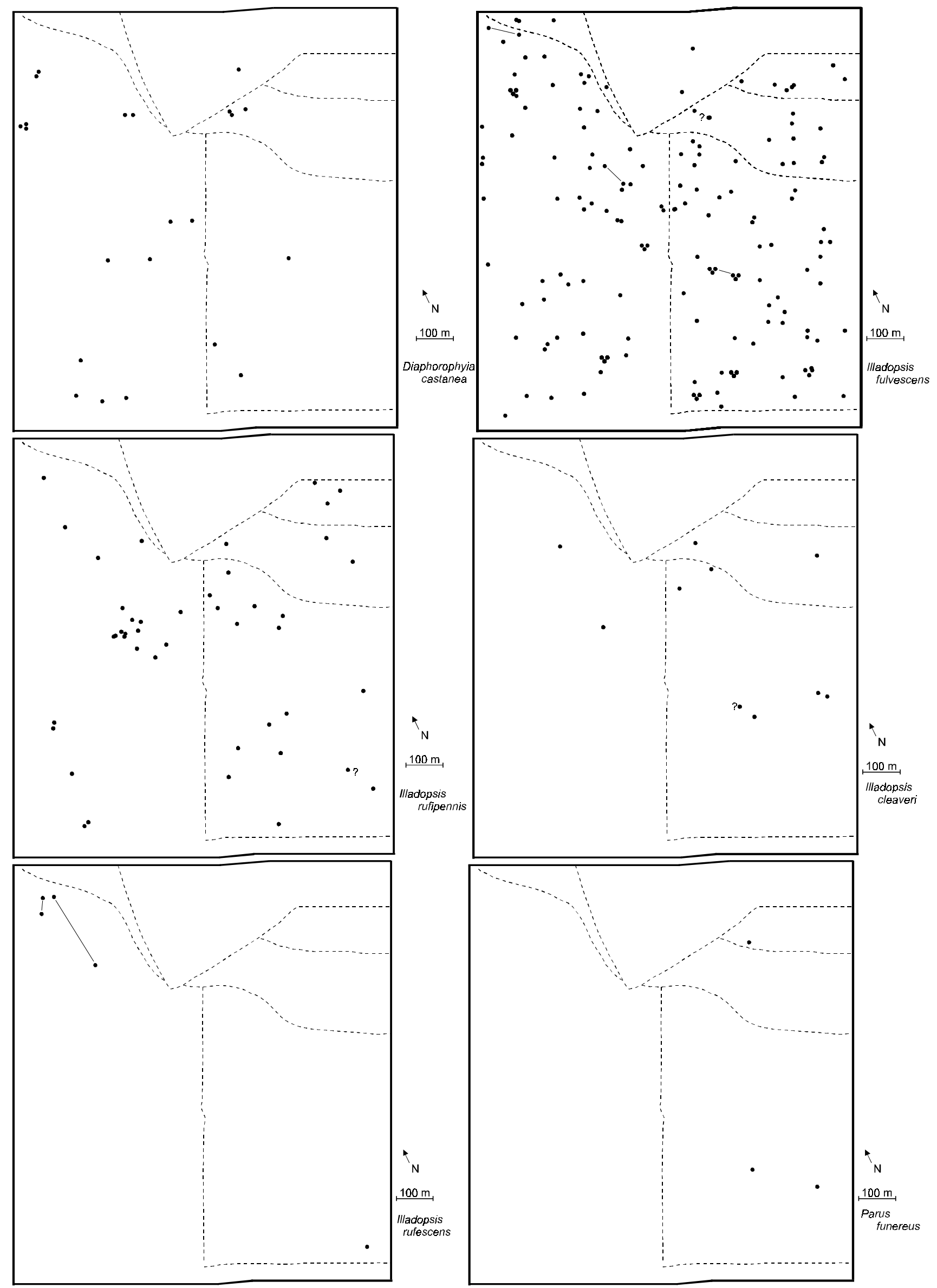


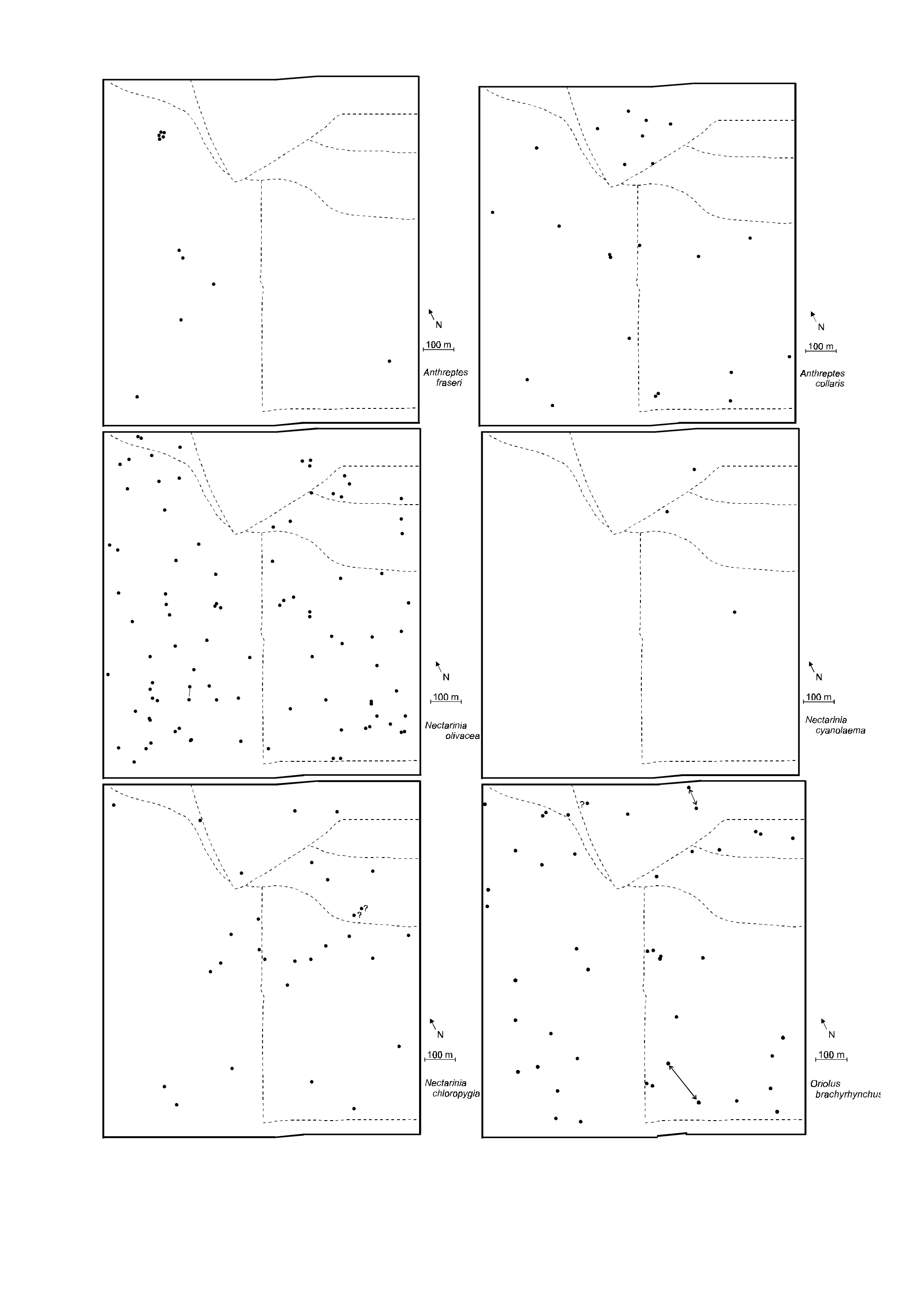




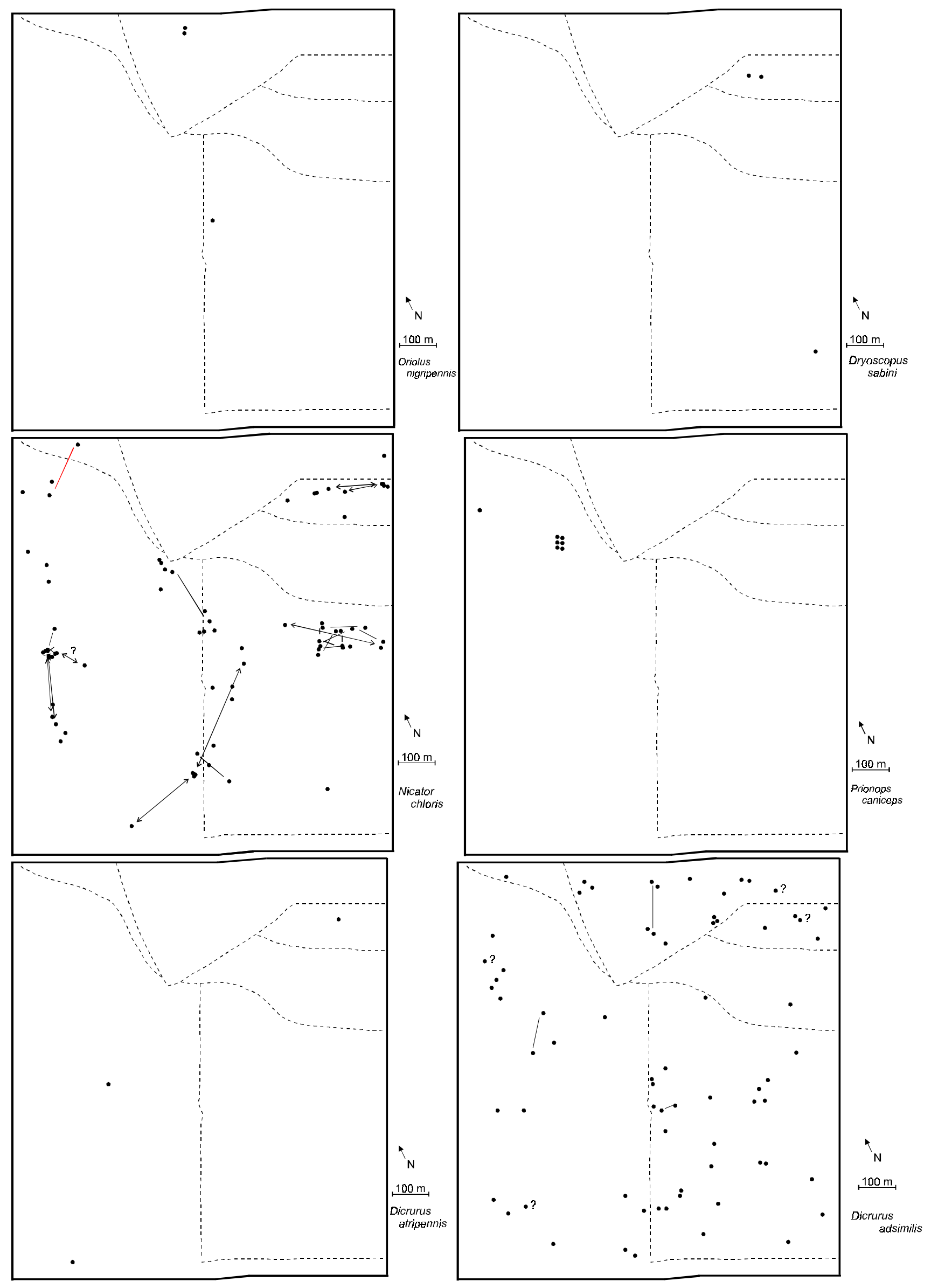




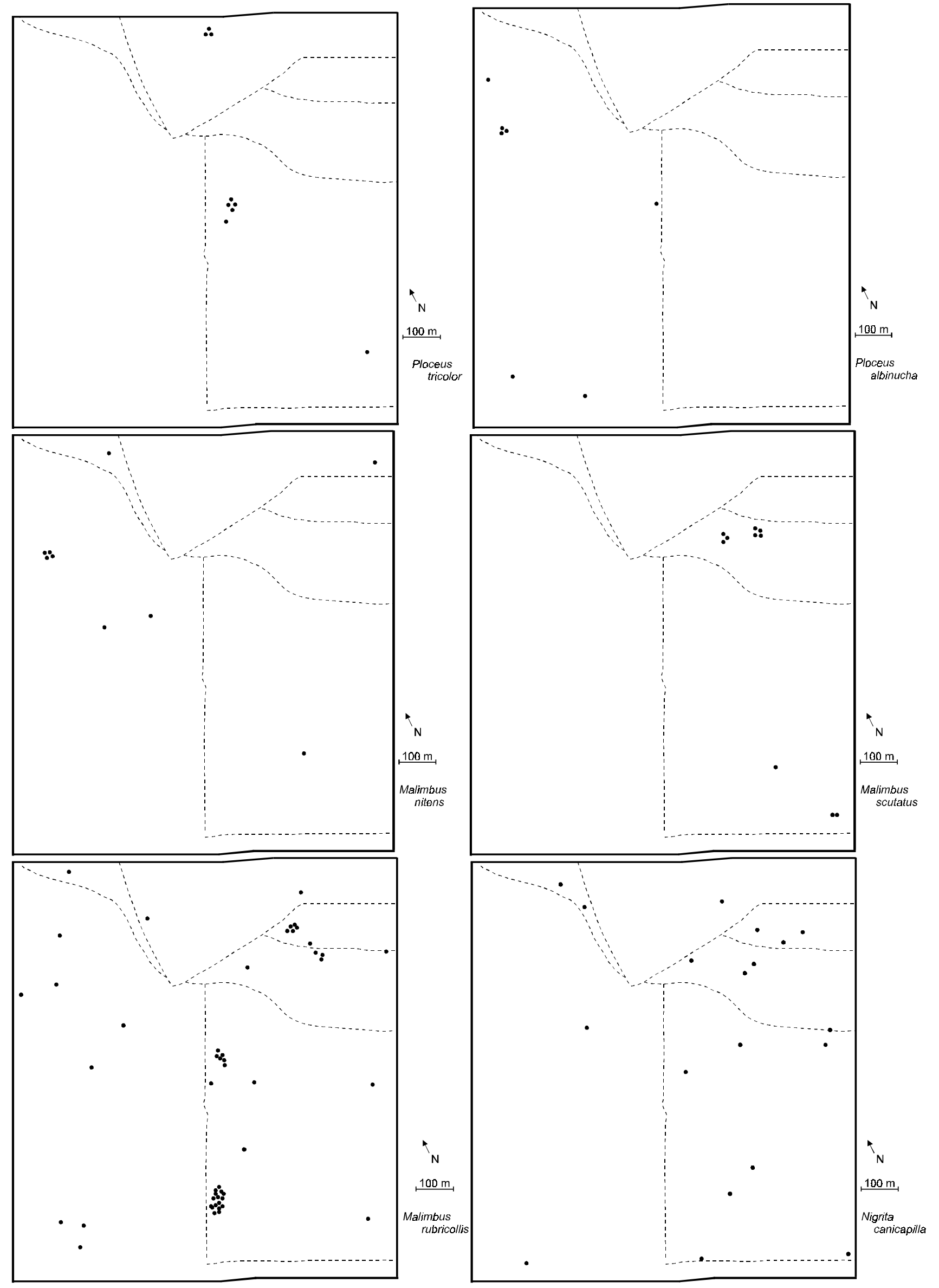




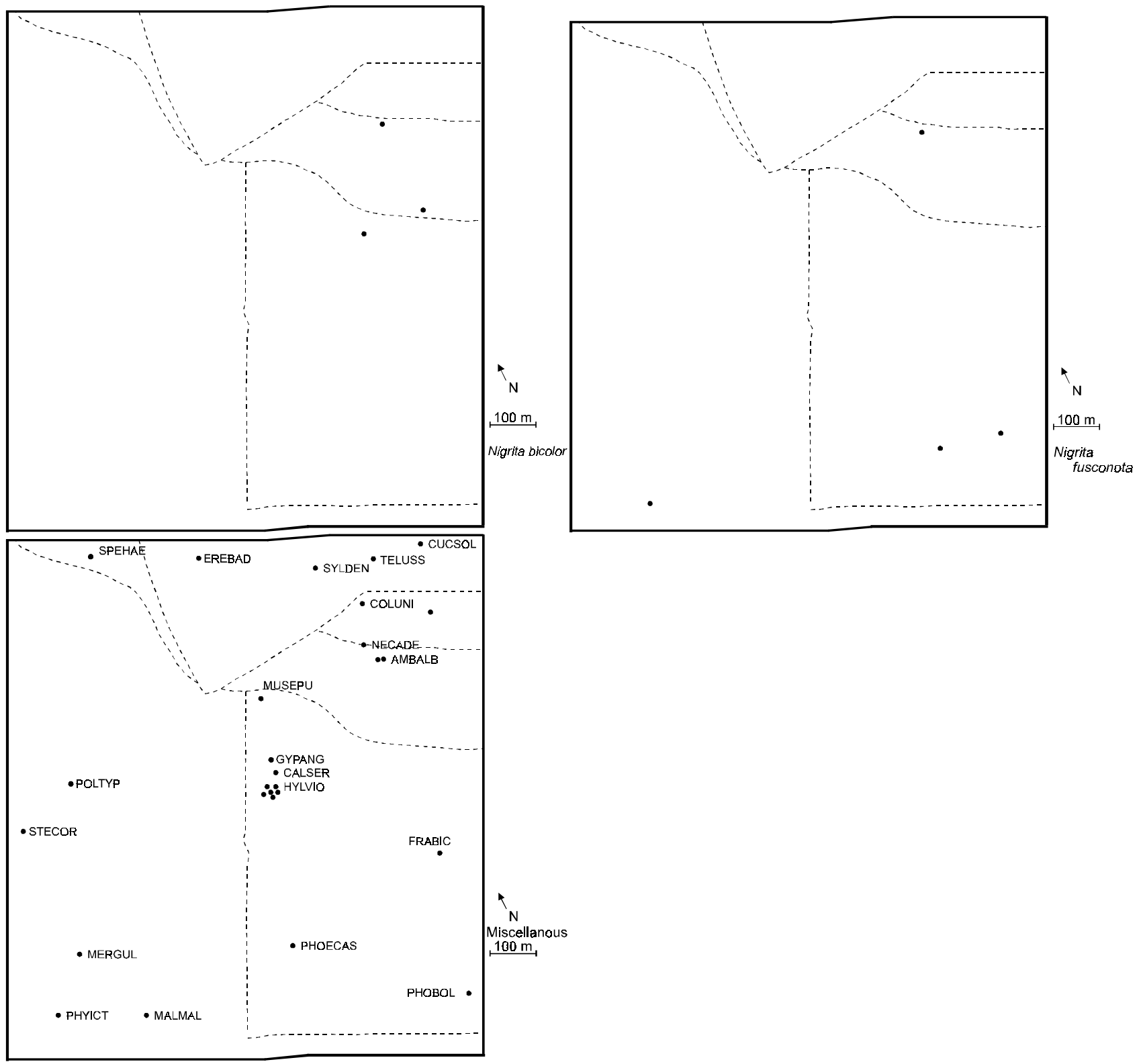



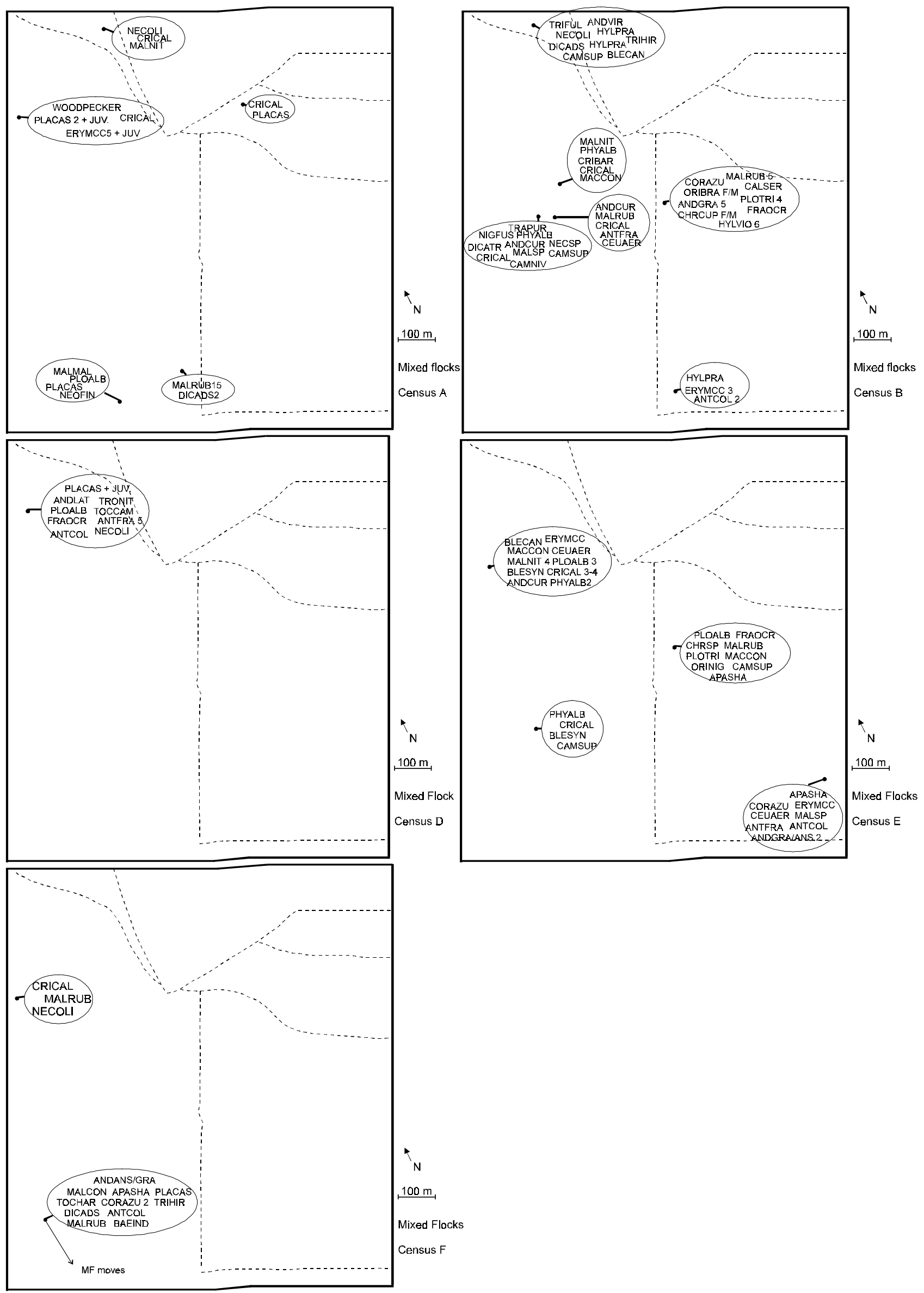


\section{Appendix E: Photographic section}

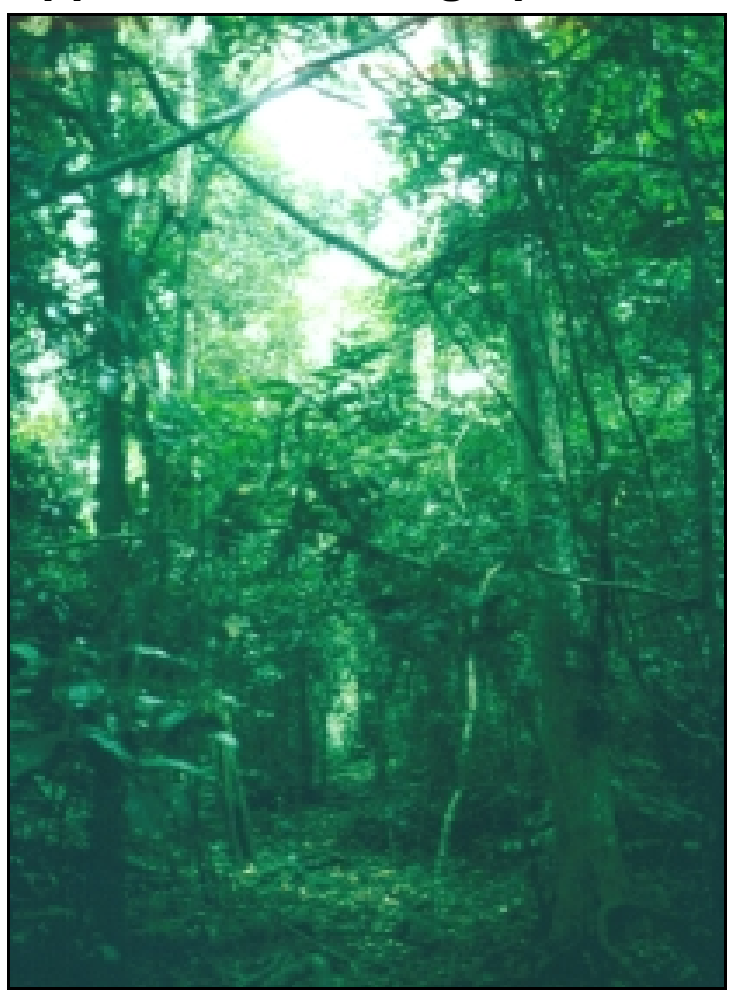

1

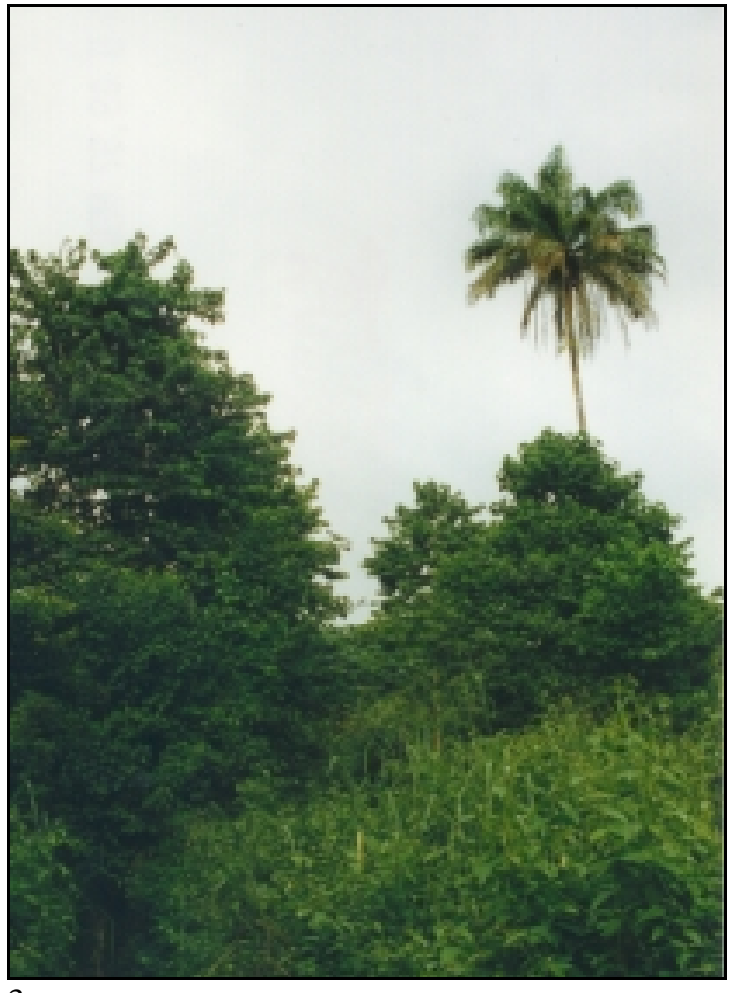

3

1 Control compartment

3 Swamp Forest

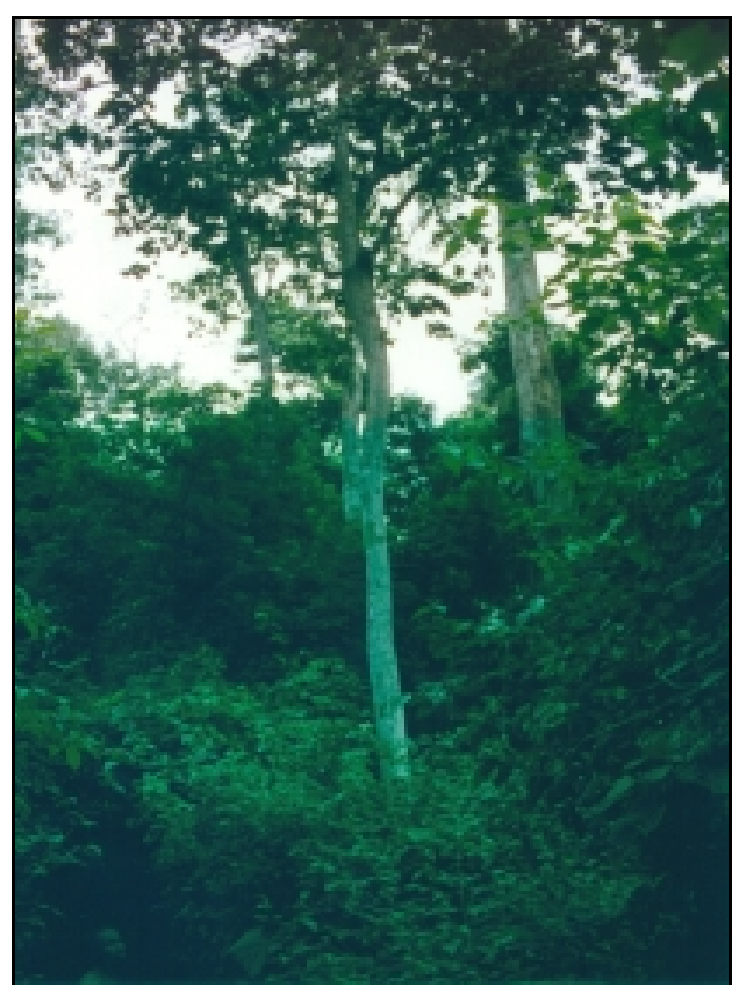

2

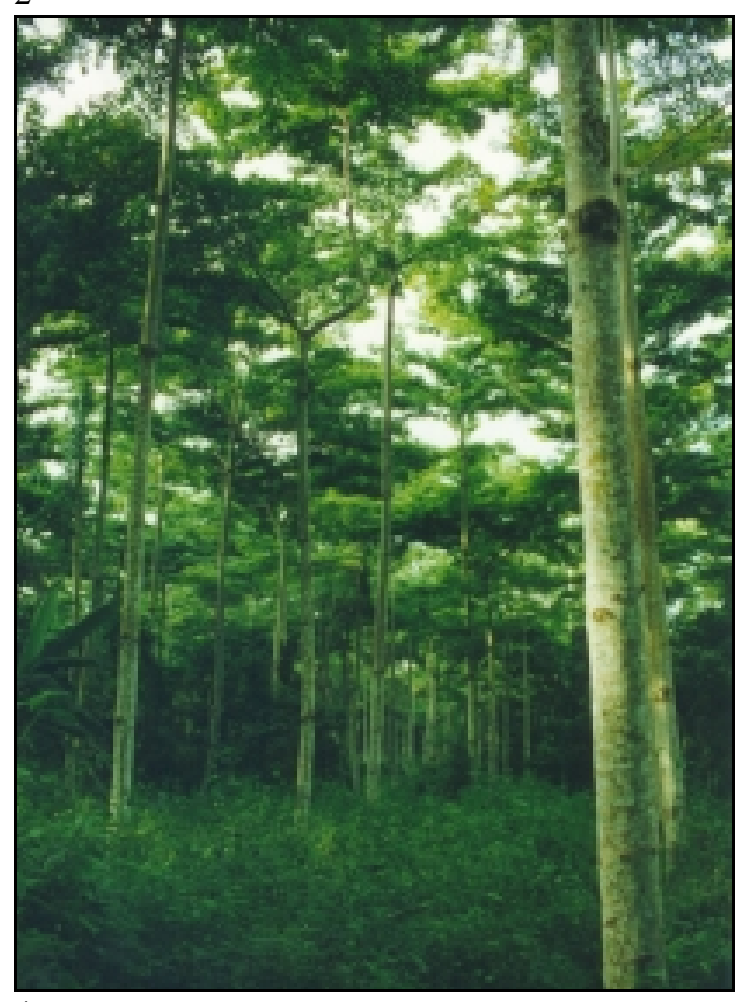

4

2 Liberation thinning compartment

4 Terminalia-Plantation 


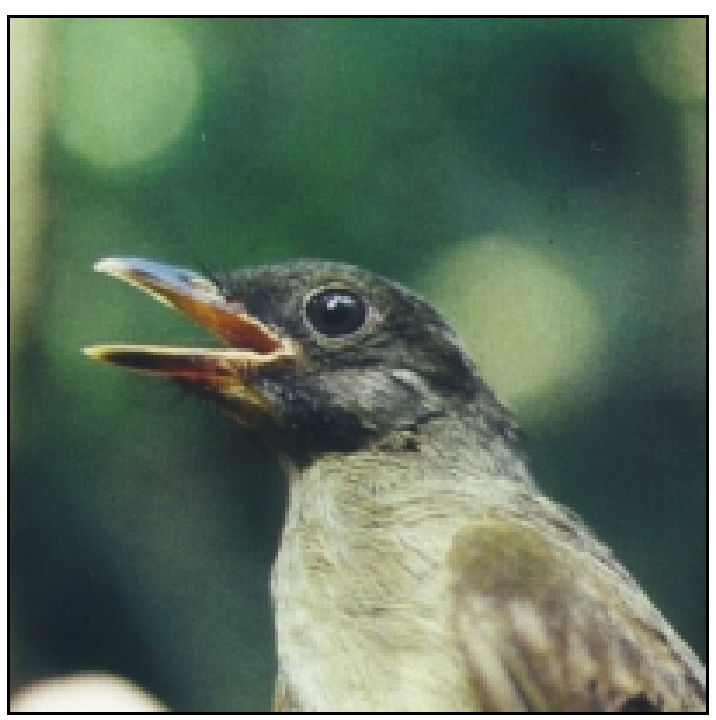

5

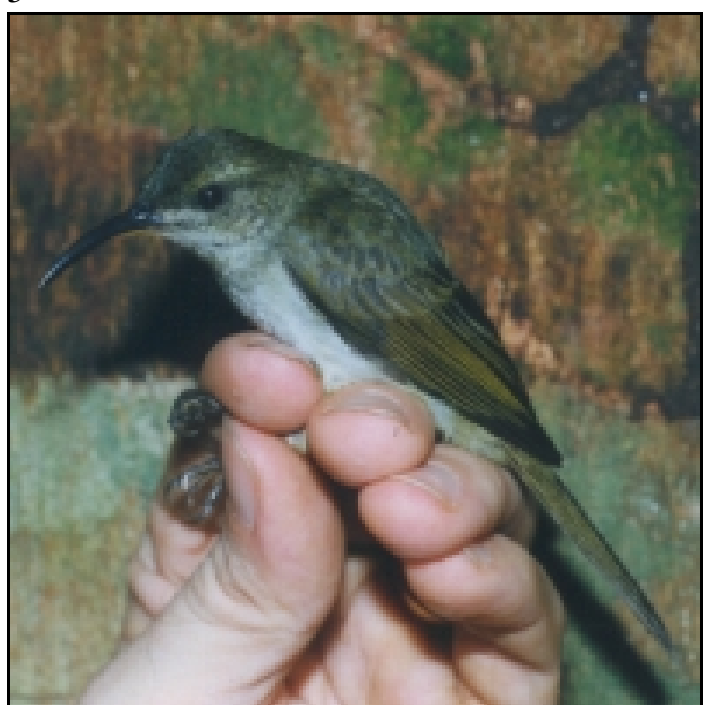

7

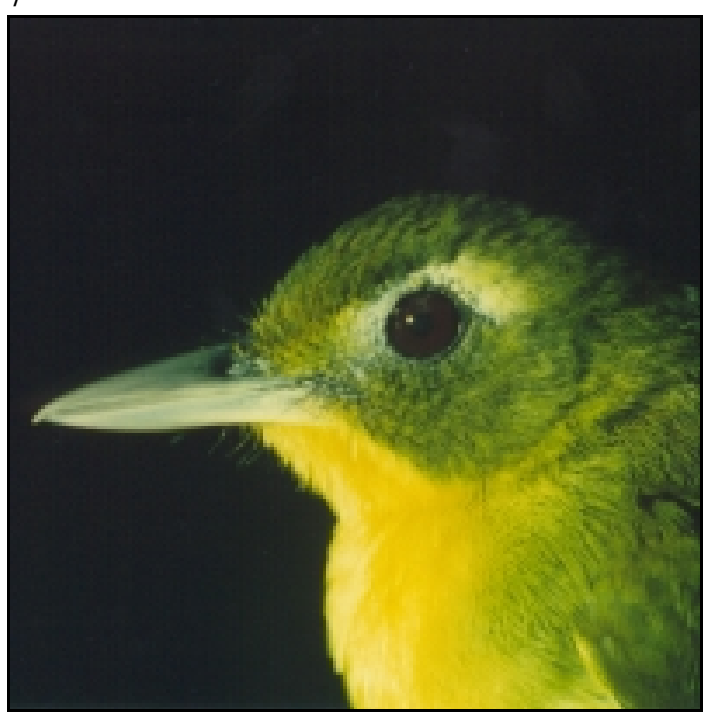

9

5 Yellow-whiskered Greenbul Andropadus latirostris

7 Olive Sunbird Nectarinia olivacea

9 Green-tailed Bristlebill Bleda eximia

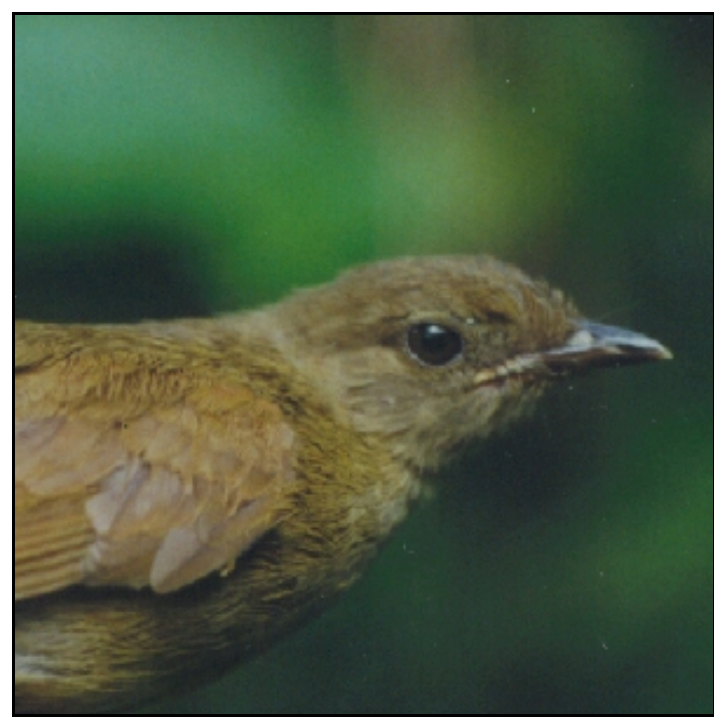

6

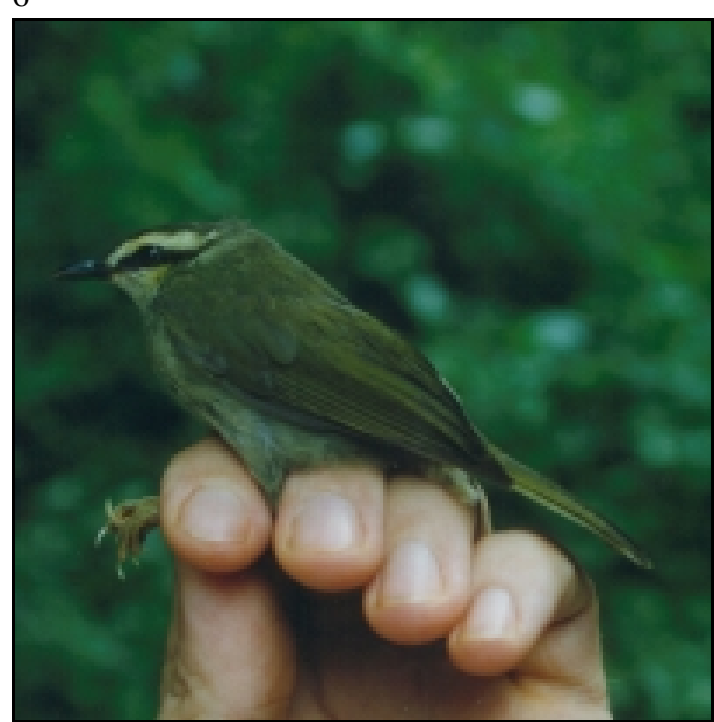

8

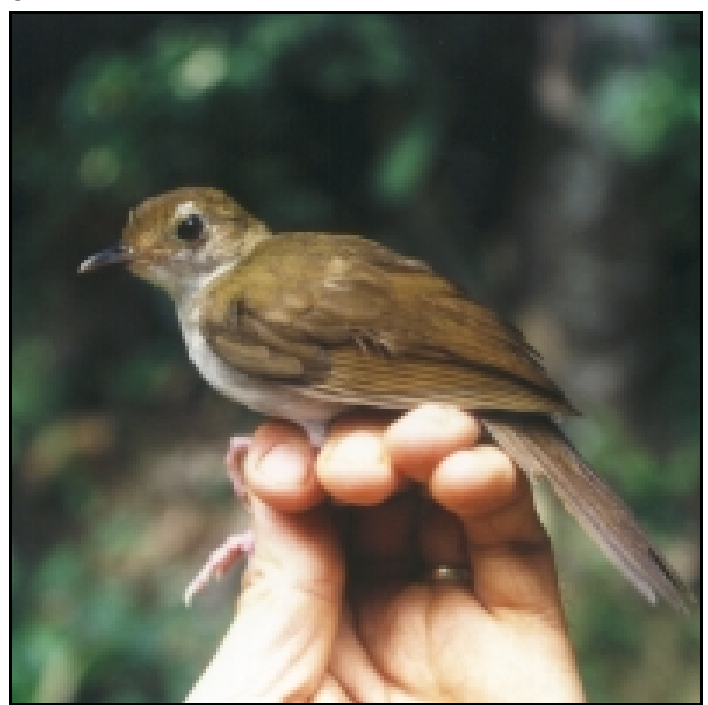

10

6 Little Greenbul Andropadus virens

8 Green Hylia Hylia prasina

10 Rufous-winged Illadopsis Illadopsis rufescens 